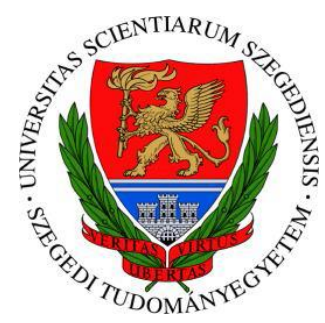

\title{
A SZŐREG-1 TELEP GÁZSAPKÁT TARTALMAZÓ TELEPRÉSZÉNEK SZEDIMENTOLÓGIAI MODELLEZÉSE
}

A telep több léptékü modellezése klasszikus szedimentológiai és geostatisztikai alapú módszerek valamint CT-vizsgálatok segítségével

Doktori $(\mathrm{PhD})$ értekezés

\section{SZILÁGYINÉ SEBŐK SZILVIA}

Témavezető:

DR GEIGER JÁNOS

egyetemi docens 
„A világ bajait nem lehet társadalmi- politikai módszerekkel megoldani;

ha lehetne, már rég megoldódtak volna (...), bizni csak a tudományban és az egyén alkotóerejében lehet."

/Lángh Júlia/ 


\section{TARTALOMJEGYZÉK}

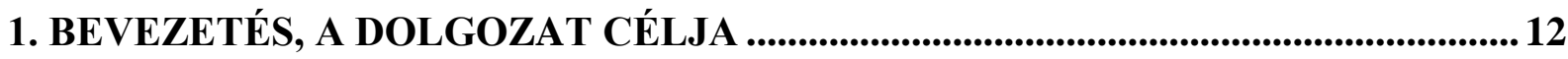

2. IRODALMI ÉS KUTATÁSI ELÖZMÉNYEK .................................................................... 14

3. ADATOK, VIZSGÁLATI LÉPTÉKEK ÉS MÓDSZEREK............................................. 21

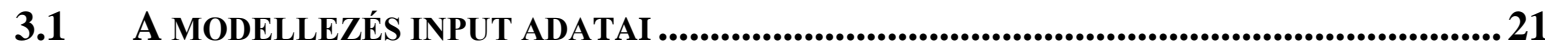

3.1.1 Kútgeofizikai, kőzetfizikai kisminta és kőzetszöveti mérések, valamint makroszkópos elemzési adatok ................................................................... 21

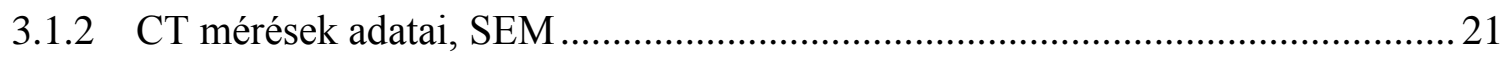

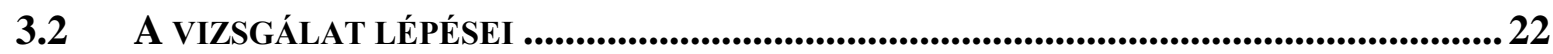

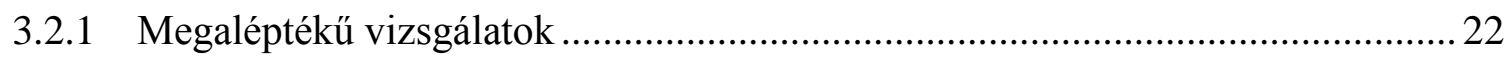

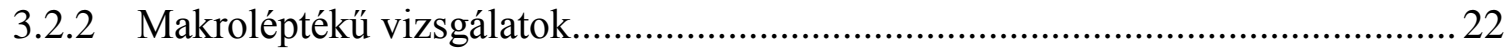

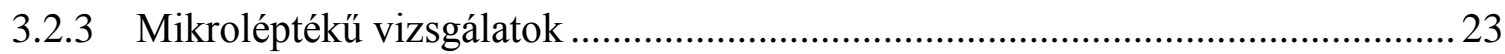

3.3 ALKALMAZOTT SZOFTVERESZKÖZÖK ÉS METODIKÁK .............................................. 25

3.3.1 A térképezés, a sztratigráfiai alapú megjelenítés, és a geostatisztikai adatfeltárás

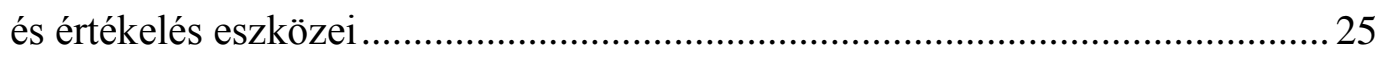

3.3.2 A CT adatok feldolgozásának szoftveres eszközei és metodikája ...................... 25

4. A FÚRÁSOKBAN ELŐFORDULÓ KŐZETTÍPUSOK ÉS MEGJELENÉSI FORMÁJUK ......................................................................................................... 27

4.1 1. SZÁMÚ FÚRÁS RÉTEGSORÁNAK JELLEMZÉSE .................................................. 27

4.2 2. SZÁMÚ FÚRÁS RÉTEGSORÁNAK JELLEMZÉSE .................................................. 28

4.3 A 3. SZÁMÚ FÚRÁS RÉTEGSORÁNAK JELLEMZÉSE ................................................29

4.4 A 4. SZÁMÚ FÚRÁS RÉTEGSORÁNAK JELLEMZÉSE ..................................................... 30

5. ÜLEDÉKFÁCIESEK DEFINIÁLÁSA ............................................................................. 32

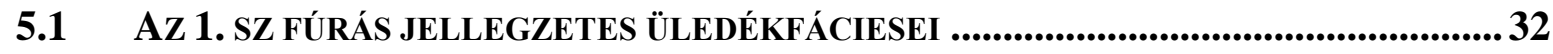

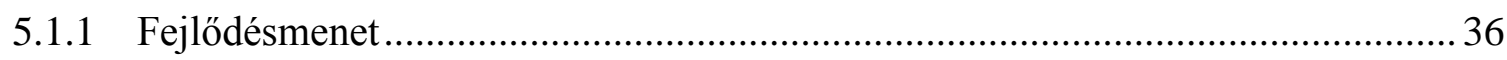

5.2 A 2. SZ FÚRÁS JELLEGZETES ÜLEDÉKFÁCIESEI.................................................. 38

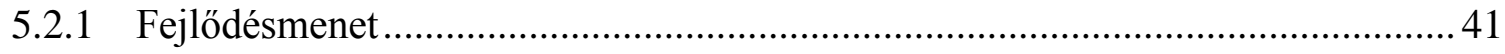

5.3 A 3. SZÁMÚ. FÚRÁS JELLEGZETES ÜLEDÉKFÁCIESEI .............................................. 43

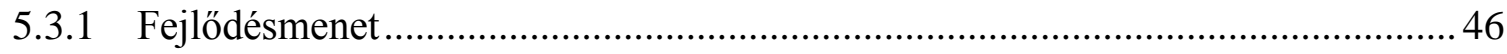

5.4 ÜLEDÉKFÁCIESEK DEFINIÁLÁSA A 4. SZÁMÚ FÚRÁS ESETÉBEN ............................. 48

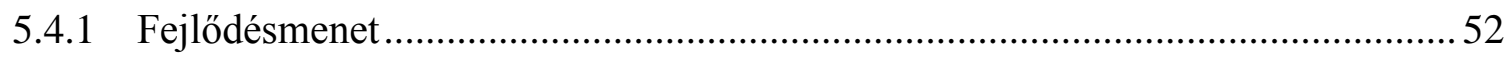


6.1 AZ ELOSZTÓ MEDREK ÜLEDÉKSZERKEZETI JEGYEI.........................................57

6.2 A MEDER ÉS TERMÉSZETES PARTGÁT-KOMPLEX ÜLEDÉKSZERKEZETI JEGYEI ..... 57

6.3 MEDERÁTTÖRÉSI LÓBA ÜLEDÉKSZERKEZETI JEGYEI .........................................57

6.4 CREVASSE CHANNEL ÉS PROGRADÁCIÓJA ÜLEDÉKSZERKEZETI JEGYEI .................. 58

6.5 MOCSÁR ÉS MEDERFELHAGYÁS ÜLEDÉKSZERKEZETI JEGYEI.............................58

7. MODELLEZÉS KÜLÖNBÖZÖ LÉPTÉKEKBEN - MIKROLÉPTÉKÜ HETEROGENITÁS- ÉS FLUIDUMÁRAMLÁSI VIZSGÁLAT CT-VEL ......... 59

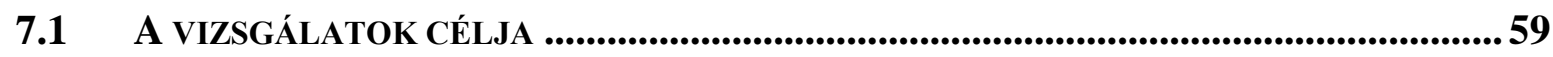

7.2 FERDE RÉTEGZŐdÉS EGYFÁZISÚ ÁRAMLÁSOS VIZSGÁlATA CT- VEL ....................61

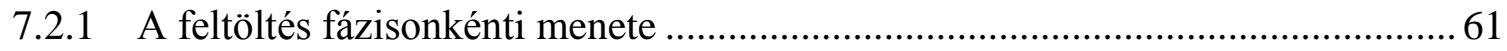

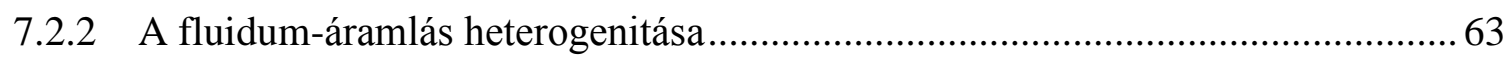

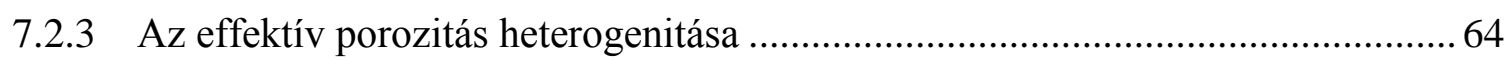

7.3 ÖSSZEOLVADÁSI FELSZÍN VIZSGÁLATA CT-VEL ...........................................65

7.3.1 Az összeolvadási felszín lehetséges hatása a fluidum áramlásokra .................... 66

8. MAKROLÉPTÉK: A SZÖVETI ÉS KŐZETFIZIKAI KAPCSOLATOK ................. 70

8.1 A KöZETSZÖVET ÉS A KÖZETFIZIKAI TULAJDONSÁGOK KÖZÖTTI KAPCSOLAT ..... 70

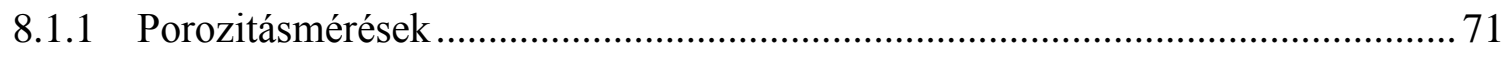

8.1.2 A folyadékos és kL ekvivalens permeabilitások összehasonlítása ....................... 73

8.1.3 A vízszintes és függőleges $\mathrm{kL}$ ekvivalens permeabilitások................................ 74

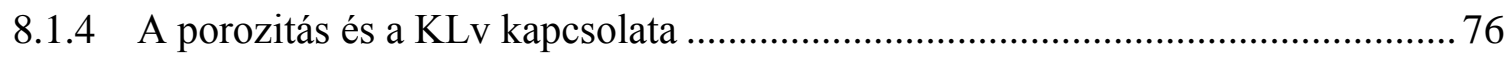

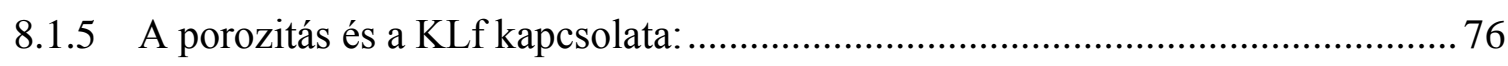

8.2 A KISMAG MÉRÉSEK TULAJDONSÁGAINAK KÖZETTÍPUSONKÉNTI JELLEMZŐ

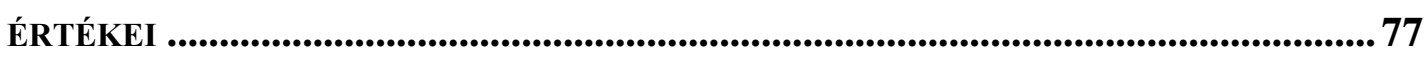

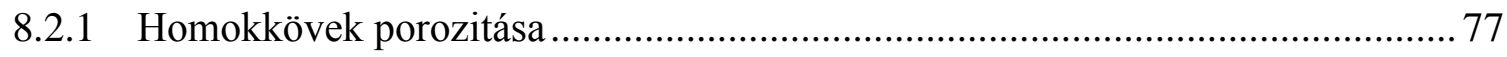

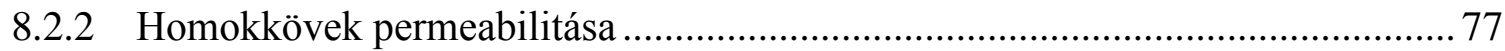

8.3 A POROZITÁS ÉS PERMEABILITÁS JELLEMZŐI AZ EGYES ÜLEDÉKES FÁCIESEKBEN78

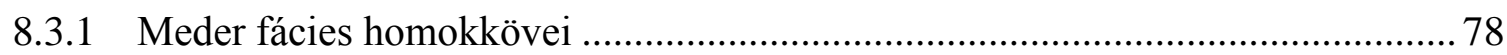

8.3.2 Meder és természetes partgát komplex homokkövei....................................... 79

8.3.3 Mederáttörési lóbák homokkövei ……............................................................... 79

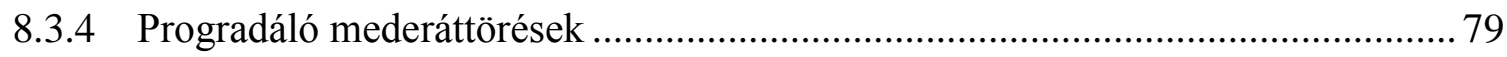

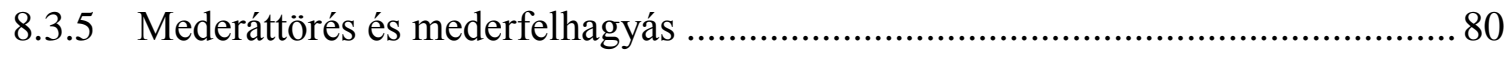

8.4 AZ ÜLEDÉKES GENETIKA MEGJELENÉSE A SZEMCSEMÉRET-ELOSZLÁSOKBAN ..... 80

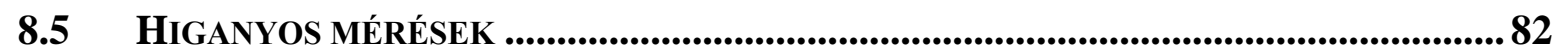


8.5.1 Az egyes pórusméret osztályok gyakoriságai.

8.5.2 A porozitás és permeabilitások kapcsolata a szemcseméret-eloszlással, pórusszerkezettel és a karbonát tartalommal

8.5.3 A permeabilitások és a pórusméret- tartományok kapcsolatai az egyes kőzettípusokon belül a higanyos mérések eredményei alapján ........................... 89

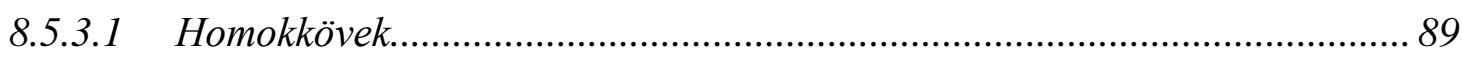

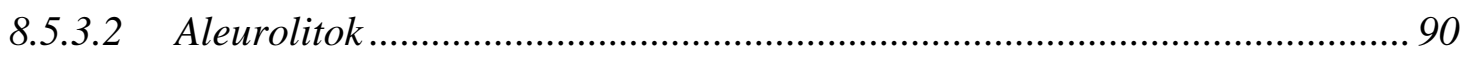

8.5.4 A permeabilitások és a pórusméret- tartományok kapcsolata az egyes üledékes fácieseken belül a higanyos mérések eredményei alapján.................................. 91

8.6 A DIAGENEZIS EREDMÉNYÉNEK KVANTITATÍV JELLEMZÉSE...............................95

9. MEGALÉPTÉK- MEDERALAKULATOK ELHELYEZKEDÉSE A VIZSGÁLT

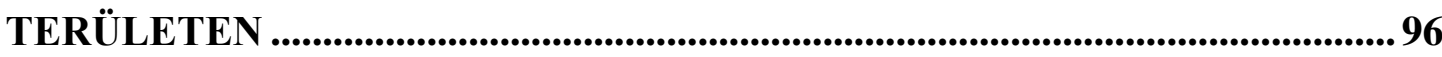

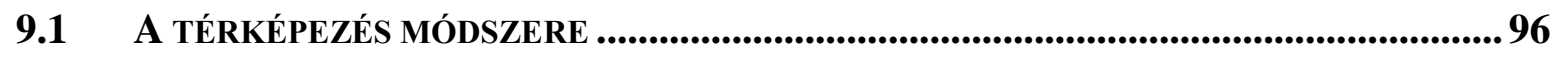

9.2 A TORKOLATI ZÁTONYOK ÉS MEDERALAKULATOK JELLEMZÉSE ............................97

9.2.1 D-DNy-i torkolati zátony- mederegyüttes fejlődésmenete................................. 98

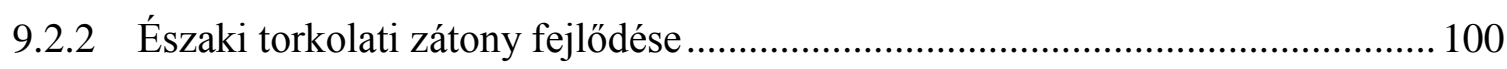

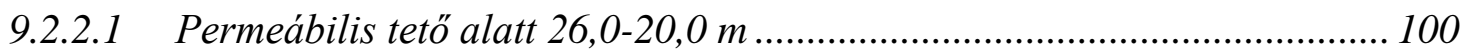

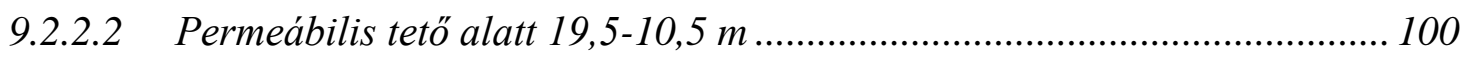

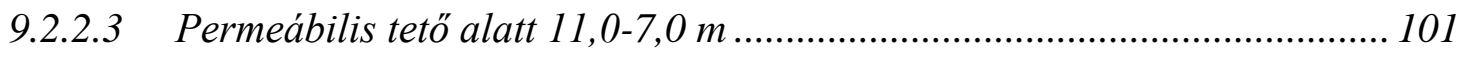

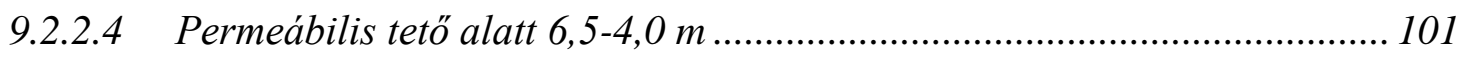

9.2.3 Keleti torkolati zátony és mederegyüttes fejlődésmenete ................................. 102

9.2.3.1 Permeábilis tetö alatt 9,0-4,0 m .............................................................. 102

9.3 A GÁZ- FOLYADÉK HATÁR ÉS AZ EGYES MEDERALAKULATOK EGYMÁSHOZ

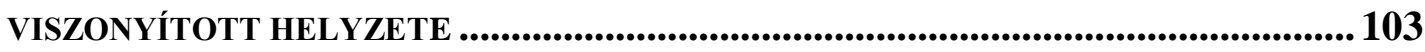

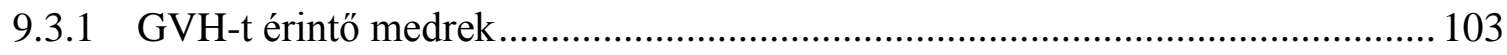

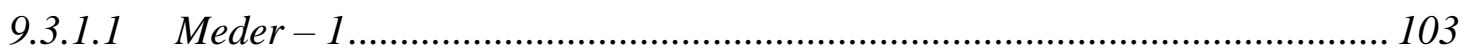

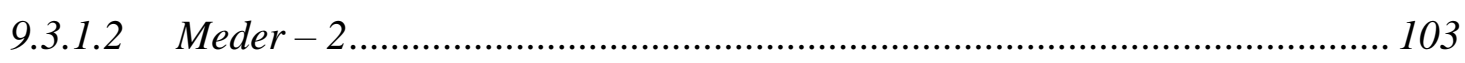

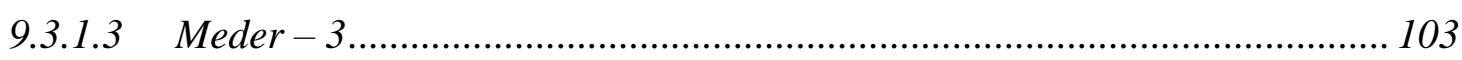

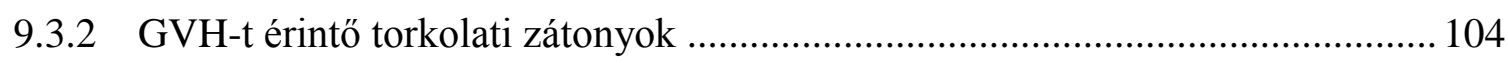

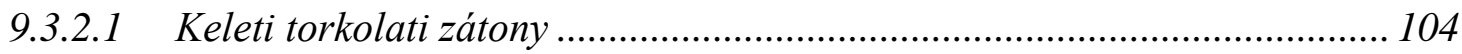

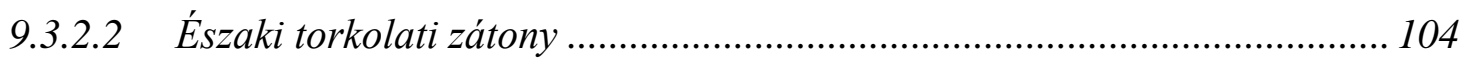

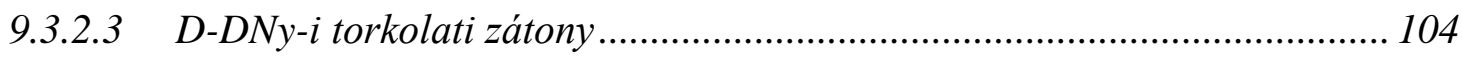

9.4 LEHETSÉGES ÁRAMLÁSVISZONYOK A GÁZSAPKA PEREMTERÜLETÉN................... 105

10. ÉRTÉKELÉS, DISZKUSSZIÓ................................................................................... 109 


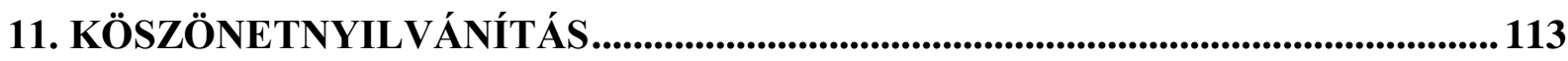

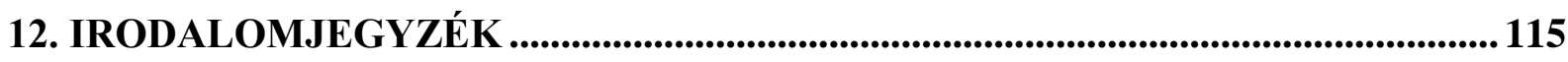

13. MAGYAR NYELVÜ ÖSSZEFOGLALÓ ..................................................................121

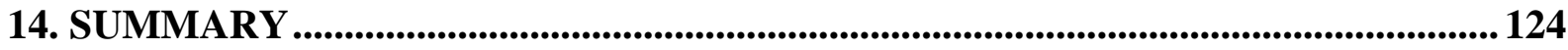




\section{RÖVIDÍTÉSEK JEGYZÉKE}
A Agyag frakció
CT Computer Tomography
CU Coarsening Upward/ Felfelé durvuló szemcseméret
FU Fining Upward/Felfelé finomodó szemcseméret
GIS Genetic Increment of Strata
GSS Genetic Sequence of Strata
GVH Gáz- víz határ
H Homok frakció
H. E. Hounsfield Egység
H. U Hounsfield Unit
PT permeábilis tető
PTA permeábilis tető alatt
PTF permeábilis tető fölött
SEM Scanning Electron Microscopy/pásztázó elektronmikroszkóp
szm szemcseméret
KLf függőleges permeabilitás
KLv vízszintes permeabilitás
k.a. kevés adat 


\section{ÁBRÁK JEGYZÉKE}

2-1. ábra A Pannon-tó feltöltődésének általános modellje ................................................... 15

2-2. ábra A Szőreg-1 telep elhelyezkedése és szerkezeti helyzete ........................................ 19

3-1. ábra A felszívásos méréshez szükséges edény CT- képe a lemérendő magmintával ......24

3-2. ábra Feltöltéses CT- mérés egyes fázisainak képe Surferben megjelenített grideken .....24

4-1. ábra A vizsgálatok során felhasznált fúrások elhelyezkedése......................................27

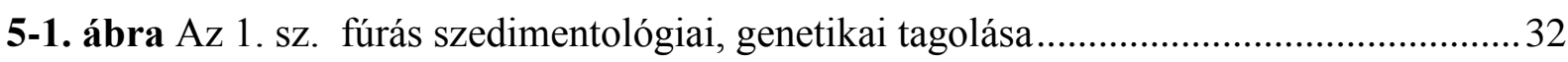

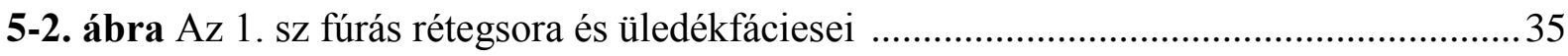

5-3. ábra Homoktartalom a permeábilis tető alatt 20 és 19 méterrel.....................................36

5-4. ábra Az 1.sz. fúrás elméleti, lehetséges múltbeli környezete a Mississippi folyó

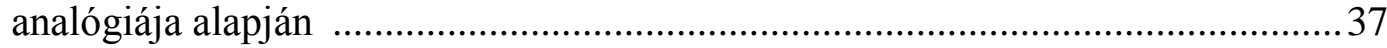

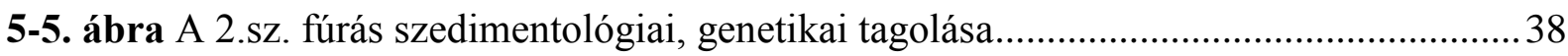

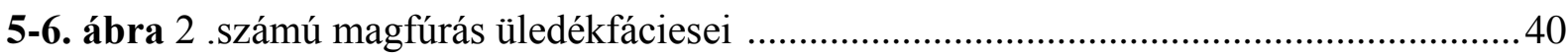

5-7. ábra Homoktartalom a permeábilis tető alatt 14,5 és 12,5 méterrel............................... 41

5-8. ábra A terület elgátolódása, a progradáció megszünése a permeábilis tető alatt 10,5

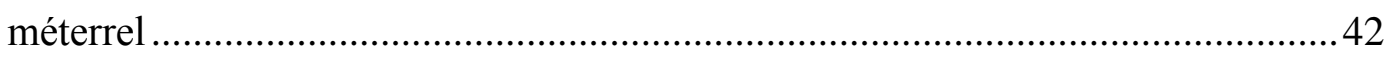

5-9. ábra A 2. számú fúrás elméleti lehetséges múltbeli helyzete a Mississippi folyó

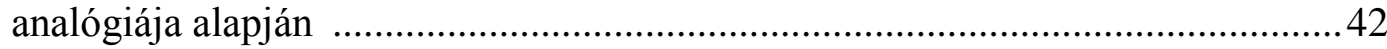

5-10. ábra A 3. számú fúrás szedimentológiai, genetikai tagolása.......................................... 43

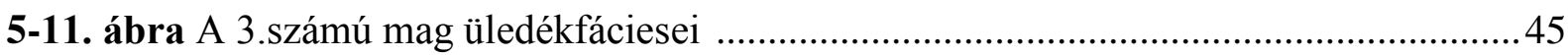

5-12. ábra Homoktartalom a permeábilis tető alatt 13,5 és 12 méterrel ................................46

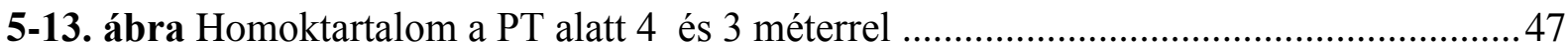

5-14. ábra A 3 sz. fúrás elméleti, lehetséges múltbeli környezete a Mississippi folyó

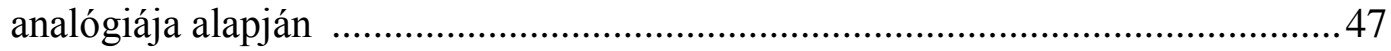

5-15. ábra A 4. sz. fúrás rétegsora és üledékfácieseinek elméleti modellje ..........................51

5-16. ábra Homoktartalom térképek a permeábilis tető alatt 24.5 és 23 méterrel...................52

5-17. ábra Homoktartalom térképek a permeábilis tető alatt 21.5 és20 méterrel...................53

5-18. ábra Homoktartalom metszeti térképek a permeábilis tető alatt 16 és 14.5 méterrel ..53

5-19. ábra Homoktartalom metszeti térképek a permeábilis tető alatt 14 és 13.5 méterrel ...54

5-20. ábra Homoktartalom metszeti térképek a permeábilis tető alatt 11.5 és 8 méterrel ….54

5-21. ábra Homoktartalom metszeti képek a permeábilis tető alatt 5,5 és 0,5 méterrel...........55

5-22. ábra A 4 sz. fúrás elméleti, lehetséges múltbeli környezete a Mississippi folyó analógiája alapján

5-23. ábra A 4. számú fúrás homoktartalom térképeinek elhelyezkedése a rétegsoron belül.56 
7-1. ábra A tárolóheterogenitás hatása a termelési folyamatokra.

7-2. ábra Ferde rétegződés egyfázisú áramlásos vizsgálatának $C T$ felvételei alapján készült gridhálók és azok korrelogramjai

7-3. ábra A fluidummal való töltöttség 3 nagyobb mozgási szakaszának megfelelő vektortérképek

7-4. ábra A száraz állapot gridje. 64

7-5. ábra A száraz és a teljes töltöttség állapotának kompozit gridje. 64

7-6. ábra Az effektív porozitás heterogenitása 65

7-7. ábra Az összeolvadási felszínt tartalmazó magminta fényképe, CT-képe és Surferben megjelenített gridje

7-8. ábra Az összeolvadási felszín lehetséges hatása a kisléptékü laterális fluidum áramlásokra..... 68

7-9. ábra Laplace egyenlet alapján előállított statikus áramlási kép 69

8-1. ábra A vízszintes és függőleges porozitás kapcsolata 71

8-2. ábra A vízszintes és függőleges porozitások box-plotjai és gyakorisági hisztogramjai .. 72

8-3. ábra A KLv és KLf gyakorisági hisztogramjai és box-plotjai .73

8-4. ábra A vízszintes KL ekvivalens permeabilitás gyakorisági hisztogramja 74

8-5. ábra $\mathrm{A}$ vízszintes KL ekvivalens permeabilitás értékek box-plotja 74

8-6. ábra A függőleges KL ekvivalens permeabilitás gyakorisági hisztogramja ................... 75

8-7. ábra A függőleges KL ekvivalens permeabilitás értékek box-plotja ............................. 75

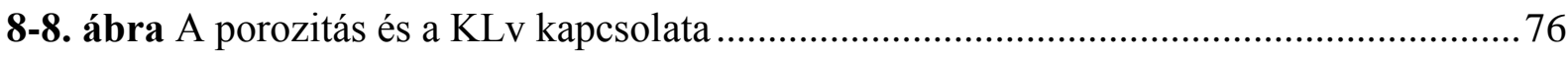

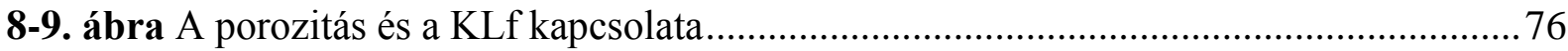

8-10. ábra A homokkövek porozitásértékeinek gyakorisági hisztogramja ............................ 77

8-11. ábra A homokkövek permeabilitásainak gyakorisági hisztogramja..............................78

8-12. ábra Az egyes fáciesekhez tartozó átlagolt, kumulatív szemcseméret-eloszlások görbéi

8-13. ábra A vizsgált minták átlagos pórusméret- eloszlása ............................................. 82

8-14. ábra A pórusméret-osztályok box-plotjai az extrém és kiugró értékekkel..................... 83

8-15. ábra Az átlagos pórusméret-eloszlás a homokkövek esetében ....................................89

8-16. ábra Átlagos pórusméret eloszlás az aleurolitok esetében ............................................90

8-17. ábra Az egyes fáciesek átlagolt kumulatív pórusméret eloszlási görbéi .......................92

8-18. ábra A függőleges permeabilitás és az átlagos pórusméretek kapcsolata az egyes fáciesekben 93

8-19. ábra A vízszintes permeabilitás és az átlagos pórusméretek kapcsolata az egyes fáciesekben 
9-1. ábra A D-DNy- i torkolati zátony-meder rendszer helyzete a PT alatt 25,5 és 17,5 méterrel

9-2. ábra A D-DNy- i torkolati zátony-meder- rendszer helyzete a Pt alatt 14 és -10,5 méter között 99

9-3. ábra $A$ D-DNy- i torkolati zátony-meder- rendszer fejlődése a PT alatt 9,5 és-7,5 méter között ...... 100

9-4. ábra A keleti torkolati zátony fejlődése a PT alatt 9- 7,5 méteres mélységben 102

9-5. ábra $\mathrm{Az}$ átlagos porozitás kontúrtérképe 106

9-6. ábra Az átlagos homoktartalom és a 20 és $23 \%$-os porozitáshoz tartozó izovonalak... 107

9-7. ábra Az áramlásos vektortérkép és az effektív homokvastagság kompozitja 108 


\section{TÁBLÁZATOK JEGYZÉKE}

5-1. táblázat 4.sz. fúrás szedimentológiai, genetikai tagolása.......................................... 48

8-1. táblázat A kőzetfizikai tulajdonságok kapcsolata ......................................................... 70

8-2. táblázat A faktoranalízisbe bevont tulajdonságok …................................................... 84

8-3. táblázat A faktoranalízis összvariancia táblázata a sajátértékekkel és a

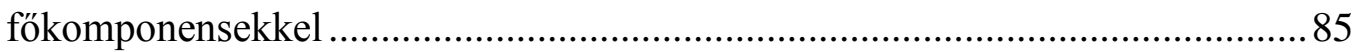

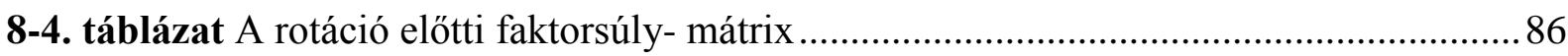

8-5. táblázat A vizsgált tulajdonságok kommunalitás értékei............................................. 88

8-6. táblázat A pórusméret osztályok statisztikai jellemzői a homokkövekben .....................90

8-7. táblázat Az aleurolitok pórusszerkezeti jellemzőinek statisztikai tulajdonságai .............91

9-1. táblázat A térképezett homoktartalom intervallumok litológiai tartalma .......................96 


\section{Bevezetés, a dolgozat célja}

2006 januárjában az Oroszország és Ukrajna közötti gázvita miatti tranzit gázszállítás kimaradásának hatására a Magyar Parlament elfogadta a stratégiai gáztároló megvalósításáról szóló törvényt, és tendert írt ki annak megvalósítására. A tender nyertese - a MOL Nyrt. megkezdte egy névlegesen 1,2 Mrd $\mathrm{m}^{3}$ mobil kapacitású biztonsági tároló tervezését, és fejlesztését. A tervezett gáztároló az Algyő mező Szőreg-1 telepében fekszik. A Szőreg-1 telep stratégiai tárolóvá történő átképzésének kettős célja volt. Egyrészt a stratégiai elvárásoknak megfelelö földalatti gáztároló létrehozása, illetve olyan eljárás bevezetése, mely lehetővé teszi a közepes komponensủ szénhidrogének gyorsított ütemü kitermelését és kihozatalának növelését a gázsapkából (NAGY GY. ET AL, 2008).

Az értekezés alapját a stratégiai tároló kialakítása kapcsán a Szegedi Tudományegyetem Földtani és Öslénytani Tanszékén 2006-2009 között futó- UX7317.10.45/95 számú- K+F projekt keretén belül részben általam elvégzett adatfeldolgozás és elemzés (GEIGER J.- SEBÖK Sz., 2008,2009), valamint a témához kapcsolódó, korábbi saját vizsgálati eredményeim (SEBÖK Sz. 2006,2008) képezik.

Jelen értekezésben a Szőreg-1 telep gázsapkát tartalmazó teleprész geológiájával pontosítani kívánom a Szőreg-1 telep felhalmozódására vonatkozó korábbi modellt különös tekintettel az egyes homoktestek térbeli kifejlődésére, valamint a kőzetfizikai tulajdonságok felhalmozódási környezeteken belüli változékonyságára. A dolgozat felépítését - a szedimentológia terén már hagyományosnak mondható - mikro-, makro- és megalépték szerint kívánom felosztani. Ennek kapcsán dolgozatomban az alábbi problémakörökkel foglalkozom:

- A magfúrások üledékes genetikai tagolása az üledékszerkezeti jegyek alapján;

- A kapott genetikai egységek térbeli kiterjesztése a fúráspontok környezetében, és ezzel együtt beillesztése egy korábbi modellbe;

- A kőzetfizikai tulajdonságok, a pórusméreteloszlás és az üledékes fáciesek kapcsolatai a Szöreg-1 telepben;

- A gáz- folyadék határ helyzete és az üledékes genetikai egységek kapcsolata;

- Mikroléptékủ áramlásviszonyok modellezése CT-mérések alapján ferde rétegződésü üledékes kőzetben, és ennek térbeli kiterjeszthetösége;

- Megaléptékú lehetséges áramlási viszonyok a telep kőzettestében.

A telep legutolsó 3D modellje a víztestből a gázsapka felé mutató mederrendszert mutatott ki, melynek átlagos szélessége 200-300 méter, hossza 4-5 km. Ennek tekintetében termelési, és tárolási szempontból nem elhanyagolható, hogy a tervezett fúrások hol, és 
hogyan harántolják a mederalakulatokat. Az újabb fúrások komplex szedimentológiai értékelése választ adhat arra, hogy az üledékfáciesek laterálisan kiterjeszthetők-e a korábbi modell által meghatározott szerkezeti helyzethez tartozó homok, vagy porozitás kontúrjaival, illetve, hogy az újabb eredmények a korábbi modellbe beilleszthetők-e, azt erősítik, vagy cáfolják.

További kérdés, hogy a mederrendszer elemeinek mikroléptékben diagnosztizálható heterogenitása milyen hatással lehet a tárolóban zajló makroléptékü folyamatokra, hogyan befolyásolhatja a tároló minőségét, müködését.

Mielőtt rátérnék a feldolgozás és elemzés menetének ismertetésére, érdemes áttekintenünk a témához kapcsolódó kutatástörténetet. 


\section{Irodalmi és kutatási elózmények}

A Kárpát-medencében előforduló, többnyire finomtörmelékes, tavi, pannóniai sorozat nagy területen és vastagságban települt. Ez az összlet kulcsfontosságú hazánk szénhidrogén, lignit és más nyersanyagvagyonának szempontjából. E két tényező együttesen eredményezte azt a tényt, hogy a pannóniai korú üledékek kutatása mára már több mint 130 éves múltra tekint vissza. A kutatási módszerek a kezdeti időktől fogva folyamatos fejlődésen mentek át, így többször volt szükség a korábbi tudományos eredmények felülvizsgálatára, revíziójára.

A pannóniai rétegekben elterjedt Congeria nemzetséget már 1835-ben leírta PARTSCH P.(1835). Művében a Tihanyból származó Congeria balatonica-t és a Congeria triangularist, Bécs környékéről a Congeria subglobosa-t, valamint a Congeria spathulata-t említi. Hazánk geológusai ekkor csak Congeriás rétegekről beszéltek. Kezdetekben a kutatások fő eszközét a biosztratigráfiai és a litosztratigráfiai tagolás, azonosítás, illetve korreláció jelentette. FUCHS TH. 1870-ben megjelent tihanyi, kúpi, és râdmânesti faunafeldolgozása. HÖRNES M. 1862 és 1870 között íródott alsópannon alapfaunájának leírása. 1875-ben $B O ̈ C K ~ J$. a Bakony földtani vizsgálata során tanulmányaiban egyértelmű Congeria emeletet különített el. Az elnevezést először TELEGDY $R$. L. (1879) használta a pontosabban meg nem határozott korú képződményekre. A pontusi és pannon elnevezés évtizedekig egymás rokon értelmü kifejezéseként volt használatban, azonban használatuk nem minden esetben volt következetes. 1880-1923 között HALAVÁTS GY. több helyi pontusi fauna leírását tette meg (HALAVÁTS GY. 1882, 1892, 1886, 1911, 1923).

LÓCZY L. 1913-ban megjelent Balaton monográfiájában a pannon képződményeket a hegyháti összletek vastagsága alapján maximum 300 m vastagságúnak gondolta. STRAUSZ L. a pannon fauna tisztázására törekedett és felismerte az üledékképződés ütemességét is (STRAUSZ L. 1949, 1971).

A részletes biosztratigráfiai leírások alapján az endemikus, tavi, puhatestü faunaleírásokra alapozva a kezdeti időkben 4-10 biosztratigráfiai egységet különítettek el. Ez a felosztás az 1950-es évekre már csak két egységre, az alsó- és a felső-pannonra szűkült.

Elterjedtté vált a két fáciesnek sekélyvízi-mélyvízi vagy partközeli-medencebeli, illetve homokos-agyagos üledékekkel való azonosítása (SÜMEGHY J. 1939, STEVANOVIC P. M. 1951, STRAUSZ L. 1971, SZÉLES M. 1971). Időnként a két fácies közti átmenetet „átmeneti fáciesként” kezelték (SZÉLES M. 1968). Ezeknek az értelmezéseknek azonban nem volt szedimentológiai alapja, és tartózkodtak az üledékes környezet értelmezésétől is. BARTA F. (1959) müve jelentős előrelépést jelentett a paleokörnyezet szerepének hangsúlyozásában. SZÉLES M.(1968) már egyértelmü átmeneti szintet különített el az alsó és felső pannon között, melyben az alsó és 
felső pannon fauna keveredését figyelte meg, viszont ezt az egyes fajok abnormális településmódjával magyarázta.

A delta feltöltődés gondolata elöször MUCSI M. (1973), MUCSI M. ÉS RÉVÉSZ I. (1975) ÉS RÉVÉSZ I. (1980) munkáiban vetődött fel a mélyebbvízi Paradacnás és a sekélyvízi Viviparusos faunák fáciesjelző szerepét, és a rétegsorban való ismétlődésüket hangsúlyozva. RÉVÉSZ I. (1980) az algyői felsőpannóniai képződmények többszörös delta ciklusainak felismerésével a feltöltődés történetének pontosabb megismerhetőségére is rámutatott, és szemléletmódja alapot adott GAJDOS et al. (1983) számára a pannóniai üledéksor litosztratigráfiai tagolására és térképezésére az Alföldön.

Az 1970-80-as évekre bizonyítást nyert, hogy az alsó és felső pannon egységek kormeghatározásra alkalmatlanok, mert egymástól eltérő üledékképződési környezeteket takarnak. Ennek felismerésében jelentős szerepet játszott az, hogy KORPÁS-HÓDI M. (1983) felismerte az alsó és felső pannon határának időtranszgresszivitását. POGÁCSÁS GY. (1984) kimutatta, hogy a korábban karotázs adatok segítségével megállapított mélyvízi alsó -és sekélyvízi felső pannon határa a medence területén eltérő időpontoknak feleltethető meg. BÉRCZI I.et PHILLIPS R. L. (1985) először alkalmazták a delta-modellt a pannon üledékekre, és az alsó-felső pannon határt egy ÉNy-i irányból progradáló delta deltalejtő-delta front határával azonosították. A Pannóniai medence feltöltődésének generalizált modelljét a 2-1. ábra mutatja (JUHÁSZ GY. 1994, BÉRCZI I. 1988 nyomán).

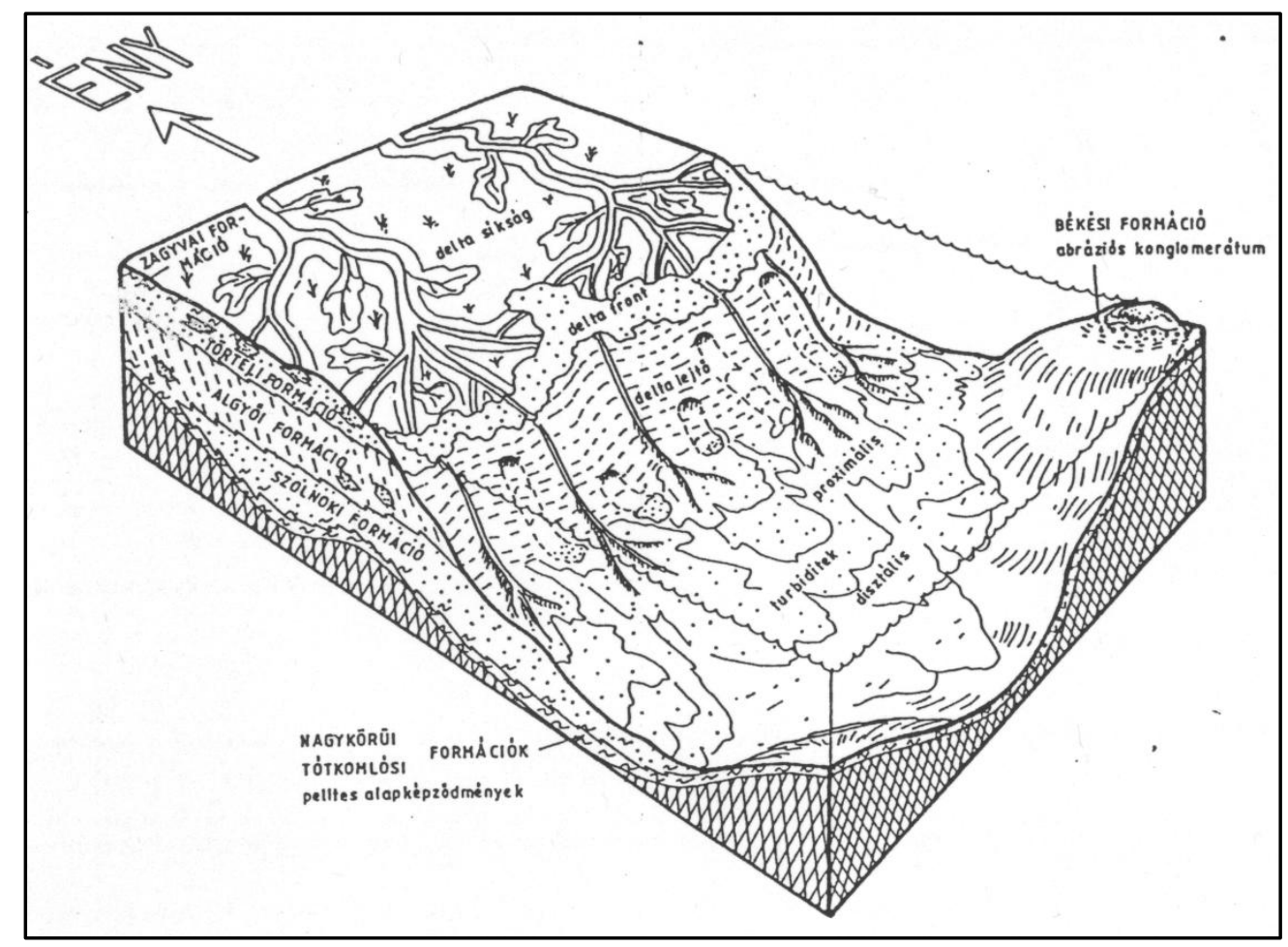

2-1. ábra A Pannon-tó feltöltödésének általános modellje (Juhász Gy 1994, Bérczi I. 1988 nyomán) 
MAtTICK, R.E - RUMPLER J. - PHILLIPS R. L. (1985) DK-alföldi szeizmikus szelvények elemzése során két ciklusban bekövetkező delta progradációs feltöltődési modellt állítottak fel, mely szerint a feltöltődés kezdetét a turbidittestekre települő mélyvízi deltasorozat jelöli ki. Feltöltődési modelljükben a ciklust sekélyvízi deltafront, majd deltasík környezet kiépülésével zárják.

A Makó- Hódmezővásárhelyi árok területén végzett 3 fúrás szeizmikus szelvényeinek, magmintáinak, szemcseméret eloszlási vizsgálatainak és geofizikai szelvényeinek alapján BÉRCZI I.(1988) 5 felhalmozódási környezetet igazolt: bazális turbiditek, mélyvízi finomszemü medenceüledékek, deltafront turbiditek, selflejtő üledékek és sekély tavi fonatos áramlás üledékei. BÉRCZI I. és társai (1988) kimutatták, hogy a pannóniai (s.1.) sorozatokon belül a medence területeken a mélymedence és a medenceszéli fáciesek átmeneti fácieseken keresztül mennek át egymásba, illetve azt, hogy az alsó pannóniai delta üledékeket a felső-pannon felé fokozatosan fluviolakusztrikus üledékek váltják fel. GEIGER J. (1988) az alföldi medence feltöltődésében szerepet játszó deltaprogradációs nagyciklusokat az üledékes kőzettest morfológiai vizsgálatainak segítségével egy megaléptékü, medencefejlődési modell kvantitatív módszerek segítségével történő felállítását tüzte ki célként. Az elemző rendszer medenceméretekben az azonosított formációkat települési jellegzetességeik alapján csoportokba rendezi. Módszerében Markov analízissel három nagy delta progradációs ciklus létét támasztotta alá. Ezek térképezett sorozata a feltöltődés tér és időbeli rendszerét mutatja az Alföld medencebeli képződményeiben.

SZALAY A .és SZENTGYÖRGYI K. (1988) olyan új litogenetikus megközelítést dolgoztak ki, melynek segítségével kimutatták, hogy a pannóniai (s.l.) sorozatok alsó, bevezető üledékeinek medencebeli elterjedése nem egységes, mivel azok csak a legmélyebb régiókban halmozódtak fel.

POGÁCSÁS GY. et al. (1989) a deltaüledékeken belül felismerhető üledékhiányokat lokális autociklusos jelenségnek tekintve fúrások rétegsorainak megnetosztratigráfiai elemzése segítségével a jelentősebb hiátusokhoz koradatokat rendeltek, melyeket később pontosítottak (POGÁCSÁS GY. et al 1992), és harmad-, illetve negyedrendü ciklusok valószínüsítése alapján a világtengerek és a Pannon-tó vízszint ingadozása közötti kapcsolatot feltételeztek.

JUHÁSZ GY. és MAGYAR I. (1992) rámutatott a pannóniai litofáciesek és a molluszkabiofáciesek közötti kapcsolatra. A SZÉLES M. (1971) által meghatározott alsó-pannont a mélyvízi fáciessel, a felső-pannont a delta síkság ősmaradványaival, az átmeneti szintet pedig a deltalejtő felső, partközeli részével és a delta fronttal azonosították. Tanulmányukban igazolták, hogy a puhatestü biofáciesek litofáciesekhez, vagyis az üledékképződési környezetekhez kötődnek, így nem jelölnek ki korhatárt. 
A korábbi téves következtetések okaiként MAGYAR I. (2004) az üledékes testeknek az addig ismertekhez képest szokatlan geometriáját, a pannóniai rétegek szabálytalan, egymás melletti településmódját nevezte meg, továbbá azt az értelmezési módot, mely szerint egy fúrással harántolt rétegsor az egész pannóniai korszakot felöleli, így az adott fúrásban kijelölhető az összes biosztratigráfiai határ. Érthető, hogy ezeket figyelembe véve a korreláció lehetetlenné válik. Mindez elkerülhető lett volna, ha nem hagyják feledésbe merülni HALAVÁTS korai felismerését, hogy a különböző rétegtani szintek kora és földrajzi elterjedése között kapcsolat van (MAGYAR I.2004).

A jelenlegi megítélések szerint a Pannon-tó a Paratethysről füződött le. A világtengerekkel való kapcsolata a kora-oligocénban, és a kora-miocénben átmenetileg megszünt. Végleges lefüződése a szarmata végén, kb 12 millió éve (Pannon-tó) történhetett meg. A lefüződés okai között szerepel az eusztatikus tengerszintesés (VAKARCS G. 1997, VAKARCS G. et al 1998) és a tektonikai tényezők (inverzió, HORVÁTH F. 1995). A lefüződés miatt a víz sótartalma ingadozott először brakk jellegűvé vált, majd kiédesedett, ami új endemikus fauna megjelenését eredményezte. A Pannon-tó üledékanyagát az Alpi-Kárpátihegységrendszer kiemelkedéséből, lepusztulásából származó üledék jelentette. A medencére bonyolult tektonikai folyamatok, differenciált süllyedés volt jellemző, több behordási iránnyal. A kialakult extenziós medencét ÉK-DNYi irányú oldal-eltolódásos rendszerek (ROYDEN L. et al, 1983), részmedencék és alaphegységi kiemelkedések tagolták. A medencerészek süllyedése térben is és időben is eltérő mértékü volt, a középső miocénban indult meg, és a pannóniai (s.l.) során vált intenzívebbé. A süllyedéssel megkezdődött feltöltődés sem volt egyenletes. A lepusztulási területhez közel eső, északi medencerészek töltődtek hamarabb, és gyorsabb mértékben, míg a déli területeken éhező medencék alakultak ki. A medence ÉK-i peremén már ekkor megjelentek a deltarendszerek. Az ÉK-i deltarendszerek mellett egy másik jelentős, ÉNy-i irányból kiinduló deltarendszer is jelen volt a medencében. Ezeket a deltarendszereket meredek lejtőjü, jól fejlett torkolati zátonyokkal rendelkező, nagy vízmélységgel jellemezhető, finomszemcsés üledékanyagot szállító Gilbert típusú deltákkal azonosíthatnánk (POSTMA G. 1990), azonban a változó üledékbehordás, a törmelék utánpótlás mértékének változása és a mobilis medrek miatt nem sorolható a torkolati zátony típusú delták közé; inkább egy folyóvíz uralta karéjos típusú delta környezet (FISHER et al, in ELLIOT, T. 1986) fejlődhetett ki. A deltarendszerek gyors progradációjának következtében a deltaelötérben és a mélymedence részekben vastag turbidit összlet halmozódott fel.

$\mathrm{Az}$ Alföld délebbi részére a terrigén üledékek sokkal később értek el. Itt pelágikus üledékképződés folyt, és a terület bazális márgák, mészmárga, valamint a kisebb szigetek 
mentén abráziós konglomerátum felhalmozódásának helyszínévé vált. Az üledékek a medenceperemek felé kivékonyodnak. A nagyobb süllyedékek - mint például a MakóHódmezővásárhelyi-árok, a Békési-medence, a Derecskei-árok, a Jászsági süllyedék - között szigetként emelkedett ki a Battonyai hát, az Algyői hát és az Endrődi magaslat.

Az 1990-es évek elején megtörtént a Magyar Rétegtani Bizottság által a medencebelsőre elfogadott pannóniai (s.1.) formációk térképezése. JUHÁSZ GY. (1992) javaslatot tett a formációk nevezéktanának térképezhetőségét és azonosíthatóságát megkönnyítő egyszerüsítésére, és 8 formációt - Tótkomlósi, Nagykörüi, Békési, Szolnoki, Algyői, Törteli, Zagyvai, Nagyalföldi Formáció - különített el.

Az Algyői Formáció delta lejtőn és medence lejtőn lerakódott sötétszürke agyagmárga. A Zagyvai Formáció fluviális és tavi eredetü, laza, szenesedett növénytöredékeket tartalmazó, közép- és finomszemű homok. A Törteli - újabb nevén Újfalui - Formáció litorális eredetü, ezen belül elsősorban delta front-delta síkság környezetben lerakódott homokkő, aleurolit és agyagmárga. A Szolnoki Formáció mélyvízi turbidit eredetű finomszemcsés homokkő, a Békési Konglomerátum az alaphegységből származó, helyi eredetű vagy kis távolságból szállított, uralkodóan metamorf és mezozoós kőzettörmelékből álló, abráziós partszegélyi konglomerátum, homokkő, ritkábban breccsa anyagú bázisképződmény (MÁFI, 1998). A neogén Pannóniai medence középső miocén- pliocén képződményeit harántoló keresztszelvényt az I-1. melléklet mutatja. A szelvény helyét az I-2. melléklet szemlélteti. Később a Nagykörüi, Vásárhelyi, Tótkomlósi és Dorozsmai Formációkat Endrődi Formáció néven vonták össze (MÁFI, 1997).

A Szőreg-1 telep a felső-pannóniai Újfalui Formációban elhelyezkedő algyői szerkezet gázsapkás olajtelepeinek egyike, mely delta síkság üledékképződéséből felhalmozódott összletekben alakult ki (2-2. ábra in NAGY GY. et al, 2008). 


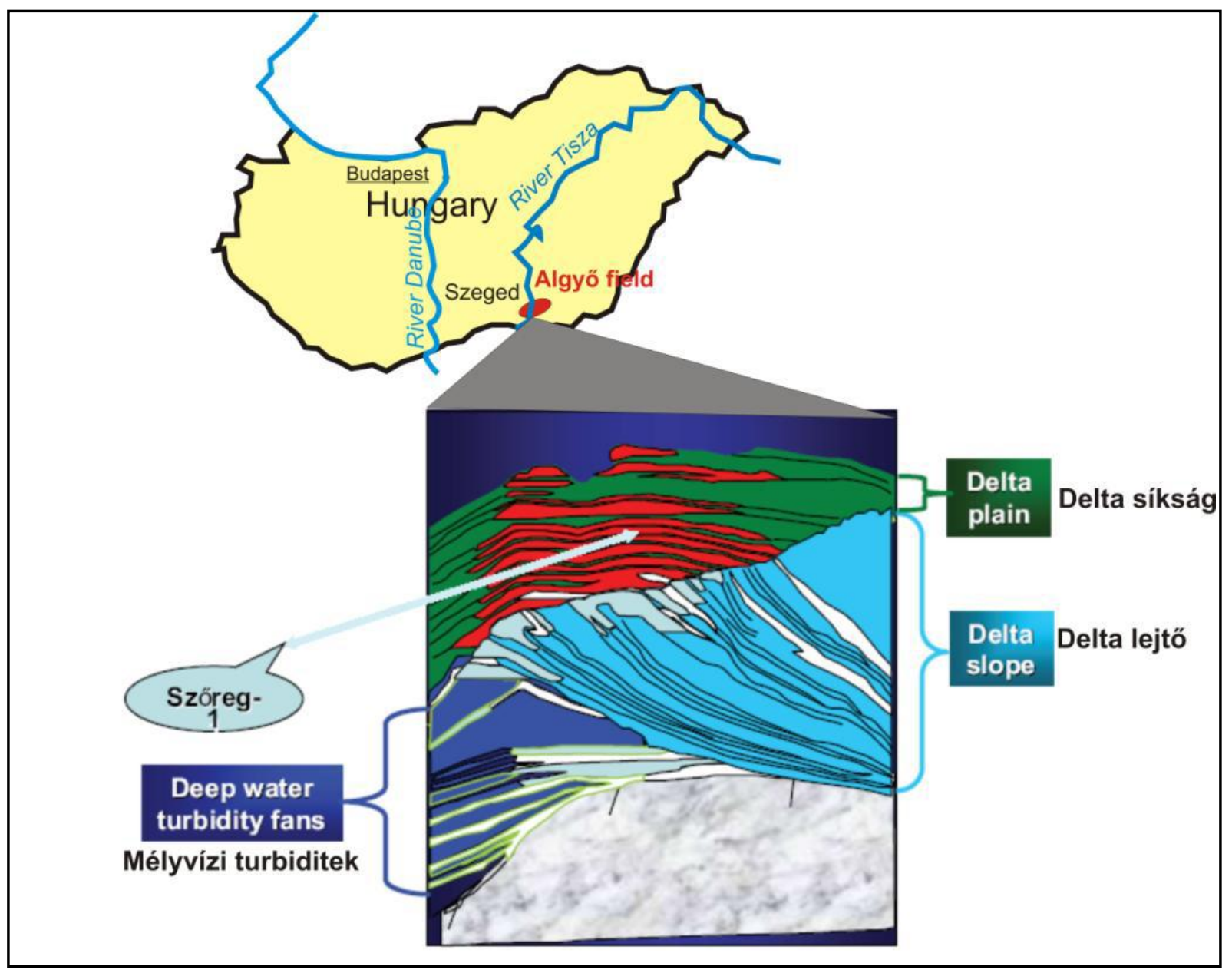

2-2. ábra A Szöreg-1 telep elhelyezkedése és szerkezeti helyzete ( módositott ábra, Nagy Gy. et al, 2008 nyomán)

A Szőreg-1 telep csapdaképző tényezőjeként a boltozati helyzetből adódó szerkezeti záródás nevezhető meg. Az összlet teljes vastagsága 25-40 méter. A telep müvelése 1967-ben indult olajtermeléssel, majd vízbesajtolással, és 1994-től gáztermeléssel folytatódott. Kúthálózata és műveléstechnológiája a korábbi rezervoárgeológiai modellre épült ( $M M B F$ 2008), azonban a kevés információra támaszkodó modell felülvizsgálására volt szükség, így az 1970-es évek kezdetén az információk egyre bővültek. Az 1979-es feldolgozás volt az első, amely 494 fúrás mennyiségi karotázs adatait használta fel, ami korábban nem állt rendelkezésre. Ez a feldolgozás a tárolót 5 rétegre bontja, melyek között összeolvadási felszínként határozták meg azokat a réteghatárokat, ahol hiányzik a rétegeket elválasztó agyagmárga-betelepülés. GEIGER J.-KOMLÓSI J. (1996) új szedimentológiai alapú geomatematikai 3D-s modellező rendszert alakított ki a törmelékes tárolókra. 1998-ban új 3Ds geológiai értékelés és szedimentológiai modell készült (GEIGER J. et al 1998), melynek fö célja a már lejátszódott, vagy a még lehetséges fluidumáramlások szimulálása. Az Algyő mezőt 1965-ben vonták termelés alá. Kihozatali tényezője kezdetben 5-10\% volt. Később a 
termelési technológiát kiterjesztették a részleges vízbesajtolásra és a gázbesajtolásra is. 1997ben a kétoldali vízbesajtolással és extenzív gázkivétellel 40\%-os kihozatali tényezőt értek el (WWW.IHS.COM). A fenti modell geocelluláris megközelítésen alapult, melynek lényege az, hogy a homoktartalmak 3D-s celláinak mozaikszerü térbeli elhelyezkedése alapján próbálja felismerni a genetikailag értelmes kőzettesteket. Ez a geocelluláris modell a szoftinformációkkal (kőzetmagok információi, rezervoár-tapasztalat) való bővítés után genetikai modellként is használható.

Az Algyő delta alkörnyezeteinek 3D modellezésével és üledékszerkezeti jegyeinek részletes leírásával (GEIGER J. 2002, 2004) foglalkozó tanulmányok a Szőreg-1 telepre készült újabb mủvelési terv pontosítását segítették elő. 


\section{Adatok, vizsgálati léptékek és módszerek}

\subsection{A modellezés input adatai}

A disszertációban közölt valamennyi diagram, geostatisztikai feldolgozás, illetve térkép adatai a MOL NyRt. tulajdonát képezik, és felhasználásuk, közlésük a MOL NyRt. hozzájárulásával történt. A feldolgozott laboratóriumi méréseket a MOL NyRt. végezte, vagy végezette.

\subsubsection{Kútgeofizikai, kőzetfizikai kisminta és kőzetszöveti mérések, valamint makroszkópos elemzési adatok}

A magmintákon akusztikus és ellenállásmérések történtek, melyek eredményeit a szöveti és pórusszerkezeti tulajdonságok vizsgálatához használtam fel. A kismag-típusú kőzetfizikai mérések közül a vízszintes és függőleges irányú porozitás, folyadékos és ekvivalens permeabilitás mérések adatait használtam fel. A függőleges porozitás, vízszintes Kl ekvivalens és folyadékos vízszintes permeabilitás mérésekből 69 adatot, a vízszintes porozitás, függőleges Kl ekvivalens és folyadékos függőleges permeabilitás mérésekből 67 mérési eredményt dolgoztam fel. A kevés mintaszám miatt a finom homokkövekre kapott mérési eredmények csak tájékoztató jellegüek.

A 4 fúrás magmintáin összesen 99 szemcseösszetételi vizsgálat, valamint 75 darab mintán kalcit és dolomittartalom meghatározás történt.

A részletes, genetikai szempontú magleírás során a kőzettípusok jellemzésén túl az üledékszerkezeti jegyek értelmezése volt hangsúlyos (GEIGER J.és SEBÖK Sz.,2009). A magok utólagos kiértékelését a magleírások mellé készült részletes fotódokumentáció is segítette (GEIGER J. és SEBÖK SZ., 2009 és III-1 - III-30. mellékletek).

\subsubsection{CT mérések adatai, SEM}

A CT felbontóképességét a mérés eredményeként kapott 512x512 pontból álló képmátrix, és a választott szeletvastagság (jelen esetben 2 milliméter) határozza meg. Ezek együttese adja meg egy voxel méretét. A voxel információtartalmát a Hounsfield Egység (továbbiakban H. E.) vagy Hounsfield Unit (H. U.) hordozza. A törmelékes üledékes kőzetek vizsgálata során a H.E.-t az adott voxelre eső szemcse, mátrix, pórus, és a pórustartalom együttes sugárgyengítési együtthatója adja, így a H.E.-t az ásványos összetétel, a diagenezis foka - a szövet érettségi fokával párhuzamosan - a posztdiagenetikus folyamatok, az üledékekre nehezedő szerkezetek súlyából eredő kompakció, valamint a nyomás alatt eltöltött idő együttesen határozza meg. Ezek következményeként a CT mint vizsgálati módszer alkalmas a makroléptékü szöveti változások, a felhalmozódás jellegében bekövetkező 
változások, valamint a térfogati sürüségben bekövetkező változások nyomon követésére, de nem alkalmas a törmelékes üledékes kőzetek ásványszemcséinek azonosítására, a pórustér, a pórustorkok méretének közvetlen meghatározására. A kőzetszövet szintjén a CT segítségével az üledékszerkezeti jegyeket kialakító folyamatok kőzetszövetre gyakorolt hatása is diagnosztizálható (GEIGER J. - HUNYADFALVI Z. - BOGNER P. 2009).

A pórustér tulajdonságainak nyomon követésére a magmintákon scanning elektronmikroszkópos vizsgálatokat végeztek (MOL NYRT).

\subsection{A vizsgálat lépései}

A vizsgálatok a maximális ismeretek megszerzése, és a komplex értékelhetőség érdekében mega-, makro-, és mikroléptékben történtek. Ez azonban nem feltétlenül jelentette azt, hogy az értékelés kizárólag a nagy lépték felöl a kis lépték felé történt. A vizsgálatok egyes késői szakaszaiban nélkülözhetetlen volt ezen ismeretek integrálása.

\subsubsection{Megaléptékü vizsgálatok}

Megaléptékben történt az üledékes genetika, és a kőzettesten belül esetlegesen lejátszódó fluidumáramlás elméleti modellezése.

A genetikai szintü vizsgálatok során a részletes, litológiai és genetikai szempontú magleírást követően történt az üledékes fáciesek definiálása, valamint komplex jellemzése. A következő lépést a magon mért üledékfácies térbeli kiterjesztése jelentette, melynek segítségével a terület üledékképződése, és kőzettesteinek térbeli lehatárolása, elkülönítése is lehetővé vált. Ez a megközelítés biztosította részben a Szőreg-1 telepet alkotó üledékes kőzettestek tér- és időbeli fejlődéstörténetének nyomozását másrészt az új és a régi ismeretek integrálását.

A tárolószintű fluidum áramlások vizsgálata a mega, makro, és mikroléptékü vizsgálatok eredményeit együttesen használja fel, így a vizsgálati lépések sorrendjében, illetve a disszertációban is a végső helyet foglalja el.

\subsubsection{Makroléptékű vizsgálatok}

A kőzetfizikai tulajdonságok, és a kőzetszövet közötti kapcsolat pontosabb megismerésének érdekében a porozitás és permeabilitás változásait a felhalmozódási környezetek tekintetében is nyomon kívántam követni. Későbbi lépésként ennek eredményeit, a mega és mikroléptékü vizsgálatok eredményeivel egy részletesebb szedimentológiai modell kialakításához, illetve egy telepen belüli fluidumáramlás elméleti modellezéséhez használtam fel. 


\subsubsection{Mikroléptékű vizsgálatok}

A CT vizsgálatok eredményeit az üledékszerkezeti jegyek belső heterogenitásának térképezésére, valamint e belső heterogenitás mikroléptékű fluidum-áramlásokra való hatásának vizsgálatára használtam fel. A mikro- és megalépték között felállított analógia alapján az eredmények a megaléptékü fluidum-áramlások elméleti modelljének felállításban nyújtanak segítséget. A CT mérések elvét és a vizsgálatok menetét az alábbiakban fejtem ki.

A magmintákat minden esetben teljes hosszukban normál CT vizsgálatoknak vetették alá, mely lehetővé teszi a kőzetmag roncsolásmentes szöveti és szerkezeti vizsgálatát (mikrolépték), a belső rétegzettség könnyü és gyors áttekinthetőségét, és segítséget nyújt a genetikailag egymástól elkülönülő szedimentológiai egységek horizontjának kijelölésére (megalépték). A vizsgált objektum roncsolásmentes vizsgálata segítségével a röntgensugárzás gyengítésének változása - mely összefügg a sürüséggel - jól nyomon követhető és az így készült feltérképező CT képek akár háromdimenziós megjelenítést és jellemzést is lehetővé tesznek. A CT felvételek a humánvizsgálatokhoz használt CT-vel megegyező, Siemens Somatom Plus 40 típusú CT-vel történtek a Kaposvári Egyetem Diagnosztikai és Onkoradiológiai Intézetében. A CT mérések a magtengelyre merőleges irányban, két milliméterenként készültek (FÖLDEST. et al, 2000)

A CT müködésének modelljét J. Radon dolgozta ki 1917-ben. Az első müködőképes készülék az 1970-es években készült el Allan M. Cormack és Godfrey N. Hounsfield munkája alapján. A CT készülékek is röntgensugárzást használnak a felvételek elkészítéséhez, de előnyük a röntgennel szemben, hogy a sugarak nem filmet exponálnak, elkerülve ezzel a kitakarási, nagyítási és sugárszóródásból adódó szürkülési jelenségeket. A CT esetében a sugarakat detektorok segítségével érzékelik, és a villamos jelekből nyert kép számítógép segítségével készül el.

A végeredményként kapott képmátrix 512x512 pixelböl áll. Minden képpont egy értékkel rendelkezik, ami az adott térfogatelem relatív lineáris sugárgyengítését mutatja. A számítógép ezeket az értékeket egy skálához rendeli a következő képlet alapján:

$$
H U=\frac{K \cdot \mu-\mu_{v i z}}{\mu_{v i z}}
$$

ahol $H U=$ Hounsfield Unit ( Hounsfield Egység), $K$ (konstans)=1000, $\mu=$ a képpontra jellemző sugárgyengítési együttható, $\mu_{\text {víz }}=$ a víz sugárgyengítési együtthatója. A Hounsfield skála két fix pontja a víz értéke (0), és a levegő (-1000). A legpuhább anyagok -100 és 100 közötti, míg a keményebbek, mint pl. a csont 600 és 2000 közötti Hounsfield értékkel jellemezhetők (ZATZ, 1981). Minden egyes Hounsfield egység növekedés $0.1 \%$ os növekedést jelent a sürüségi skálán (AKIN, S. és KORSCEK, A. R. , 2003 ). 
Néhány magmintán mikroléptékü vizsgálatokra nyomás alatti folyadékfelszívásos mérés is történt egyes konkrét üledékszerkezeti jegyek belső heterogenitásának térképezésére. Ezek a minták a Szőreg-1 teleppel azonos genetikájú telep mintái közül kerültek ki. A méréshez a magmintának a mérést megelőző 24 órán keresztül történő vákuum alatt tartása szükséges egy speciális üvegből készült, szeleppel ellátott edényben, melynek CT képét a 3-1. ábra mutatja.

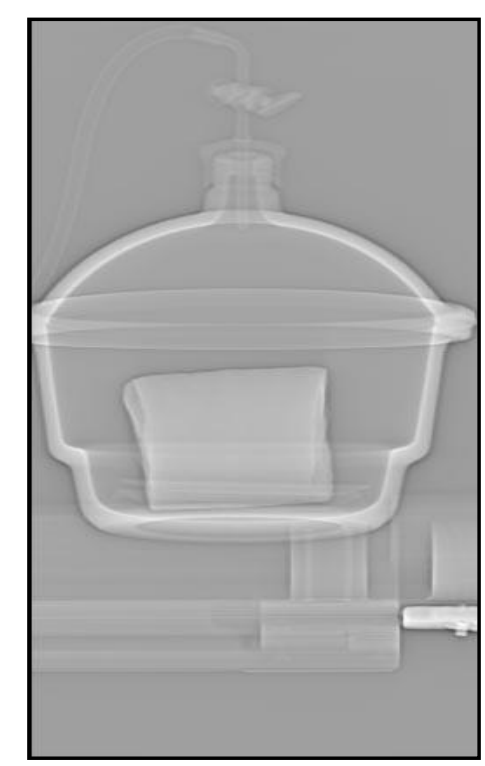

3-1. ábra A felszivásos méréshez szükséges edény CT- képe a lemérendö magmintával

Ezt követően megkezdődhet a mérés. Az edényen található szelepen keresztül történik a fluidum - jelen esetben víz - beengedése a rendszerbe. A víz az edény oldalfalain lefolyva alulról kezdi el feltölteni azt. A feltöltés során szünet nélküli mérés történik, így jól nyomon követhetőek az egyes feltöltési, ill. töltöttségi fázisok (3-2. ábra).

A CT mérés adatait előbb képmegjelenítő eljárással, majd numerikus úton is elemeztem.

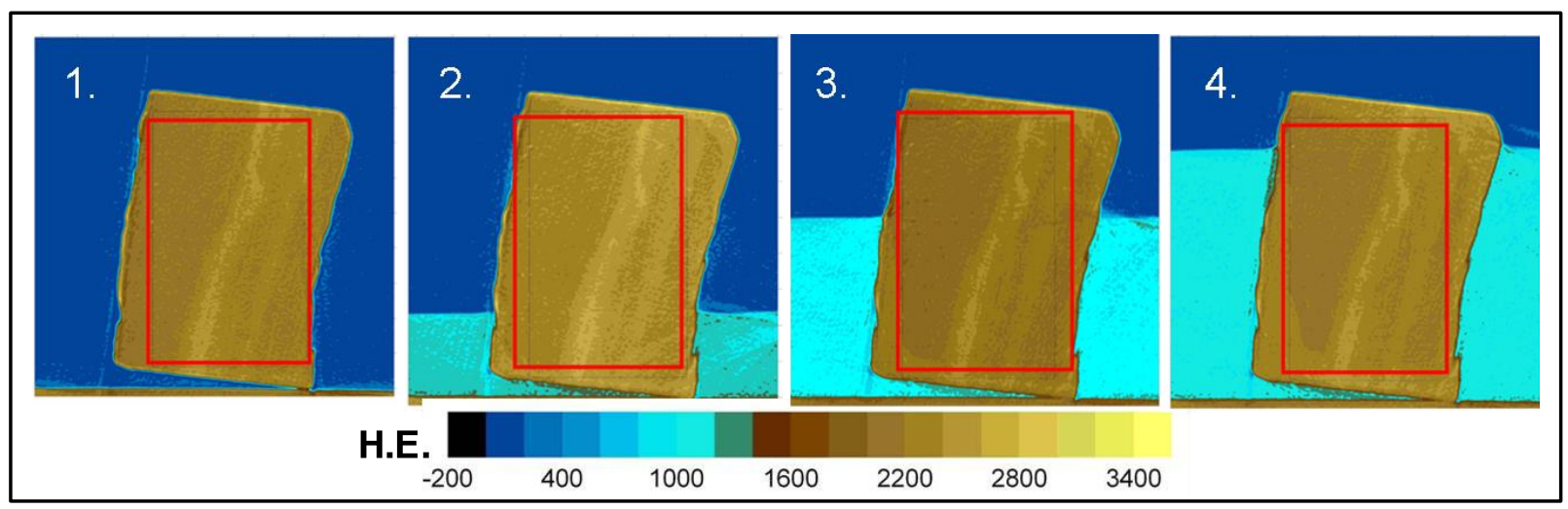

3-2. ábra Feltöltéses CT- mérés egyes fázisainak képe Surferben megjelenitett grideken 


\subsection{Alkalmazott szoftvereszközök és metodikák}

\subsubsection{A térképezés, a sztratigráfiai alapú megjelenítés, és a geostatisztikai adatfeltárás és értékelés eszközei}

A térképezéshez a Surfer 8.00 (Golden Software) verziószámú programját alkalmaztam. A vizsgált terület fél méteres mélységenkénti homoktartalom, porozitás és koordináta értékek mátrix file-ban történő elhelyezését követően a program az adatokból egy gridhálót állít elö. A választható felbontású gridháló alkalmas kontúrtérképek és 3 dimenziós hatású felszínek megjelenítésére is. A gridelési algoritmus típusának és a térképek felbontásának beállítása a programban opcionális.

A CT mérések eredményének képi megjelenítését célzó utolsó lépés során is ez a program bizonyult megfelelőnek.

Az üledékes rétegsorok megjelenítése a Strater (Golden Software), fúrólyukak és lyukszelvények grafikai megjelenítésére alkalmas programjával történt.

A statisztikai alapú adatfeltáráshoz az SPSS Statistics 11.0 (IBM termék), és a StatGraphics Plus 5.1 (StatPoint Technologies) programot használtam. Ezek lehetővé tették a mért adatok hatékony feldolgozását, a szignifikáns kapcsolatok feltárását, és azok grafikai megjelenítését is.

\subsubsection{A CT adatok feldolgozásának szoftveres eszközei és metodikája}

A vizsgálathoz szükséges szoftverek részben az adat-előállításhoz, adatkezeléshez (MVE Medical Volume Explorer, Med Image - University of North Carolina , Osiris University Hospital of Geneva, $A F E N E ́ B E$ ), részben pedig az adatok feldolgozásához, geostatisztikai értelmezéséhez szolgáltattak segítséget ( Surfer 8.0 - Golden Software, StatGraphics, SPSS Statistics 11.0 ).

A CT mérés eredményeként kapott Papyrus formátumú fájlokat az Osiris 4.0. - a Genfi Orvostudományi Egyetemen kifejlesztett - szoftver segítségével lehet megtekinteni. A program segítségével nem csak a 2 milliméterenként készült szeletek megtekintésére, a vizsgálandó szeletek kiválasztására van mód, hanem azokon adott esetben különböző méréseket is végezhetünk. A további feldolgozáshoz azonban ebben az esetben a Papyrus fájlok dicom fájlokká való konvertálására volt szükség, mely ugyancsak az Osiris programmal valósítható meg. Az így kapott dicom kiterjesztésű fájlokból további konvertálást követően a Med Image szoftverrel könnyedén mátrix fájlokat állíthatunk elő, melyek alkalmasak a Surfer 8.0. programban az adatok képi megjelenítésére, úgy, mint gridhálók, autokorrelogramok, statikus áramlási képek, háromdimenziós hatású felszíni megjelenítések előállítására. 
Ez a módszer azonban csak a magtengelyre merőleges irányú CT szeletek elemzéséhez használható, ugyanis a mag hosszúsága miatt a hossztengellyel párhuzamos mérések magas mérési zajokat eredményeztek, miáltal a hossztengellyel párhuzamos szeletekből kinyert adatok helytelen információkat eredményeztek volna. Ezért szükség volt egy, a hossztengelyre merőleges, mérési zajoktól mentes szeletekből az eredeti magtérfogatot előállítani képes programra. Ezt a lépést szolgálta az AFENÉBE (CT Adat Feldolgozás Előkészítése Nevezetes Értékek Beolvasztása Ellen, GEIGER J. 2005, GEIGER et al. 2008). Az így kapott magtérfogat alkalmas volt egy hosszanti metszet előállítására bármely tetszőleges sík mentén, amely már kellő pontossággal szolgálta a további statisztikai módszereket. 


\section{A fúrásokban előforduló kőzettípusok és megjelenési formájuk}

A vizsgálatokhoz felhasznált fúrások Szőreg-1 telepen belüli elhelyezkedését a 4-1. ábra szemlélteti. A fúrások által harántolt kőzettípusok leírásának egyszerüsített, összefoglaló táblázatát a II-1. melléklet tartalmazza. A rétegsorok jellemzését a 4.1-4.4 alfejezetek tartalmazzák.

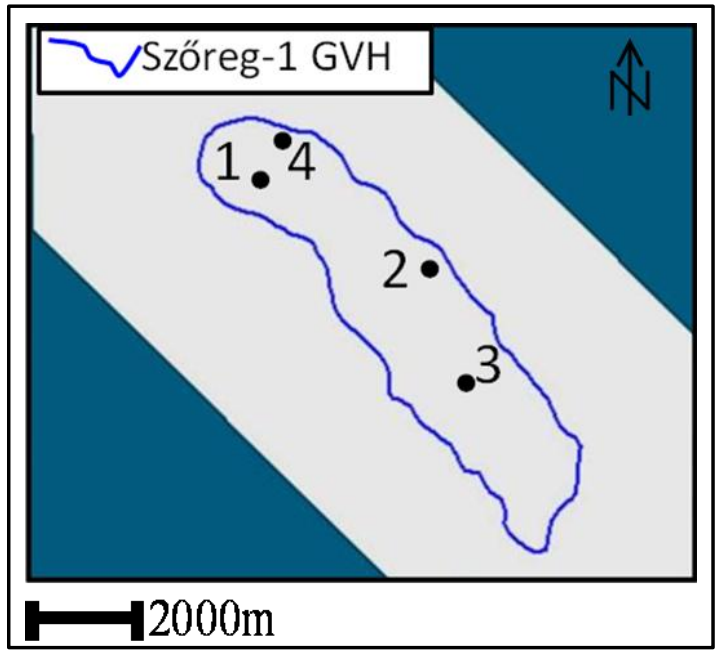

4-1. ábra $A$ vizsgálatok során felhasznált fúrások elhelyezkedése

Az üledékes rétegsor felosztásakor két, Busch által (BUSCH, 1971 IN R. C. SELLEY, 1996) bevezetett fogalmat használok: a Genetic Increment of Strata (továbbiakban GIS), és a Genetic Sequence of Strata (továbbiakban GSS). Az előbbi az üledékes kőzetek olyan összessége, melyben a fáciest, és üledékes környezetet meghatározó üledékek genetikailag egymáshoz kapcsolódnak, az utóbbi ennél tágabb fogalom: az azonos genetikai típussal leírható rétegekből nem csak egyetlen réteget foglal magában, hanem azok sorozatát. Mindkettő általában lyukszelvényekből is visszavezethető, és szeizmikus szekvenciákkal történő kalibrálást követően könnyen térképezhető, valamint rokon a későbbiekben bevezetett paraszekvencia és paraszekvencia-együttes fogalmaival.

A GSS sorozatokban ismétlődő GIS egységek által a ciklikus üledékképződés jól nyomon követhető, melyre a vizsgált magfúrásokban több példa is előfordult.

\subsection{1. számú fúrás rétegsorának jellemzése}

Az első fúrás rétegsora 7 GIS egységre tagolható. A 7. felhalmozódási egység a PT alatti 19,5 méteres mélységben finom apróhomokkővel kezdődik, melynek tetején a magátmérőnél alig kisebb, $0,5 \mathrm{~cm}$ vastag szenesagyag intraklaszt jelenik meg. A homokkő szaggatott, hullámos rétegződésü, benne agyagmárga és aleurolit intraklasztok láthatók. Az egység vastagsága 0,42 méter. Ezt követően a 6. GIS egységben agyagmárga és finom 
aleurolit suvadásos szerkezete jelentkezik, majd a két kőzettípus pár milliméteres rétegződése figyelhető meg. Erre 8,21 m vastagságban finomhomokos apróhomokkő települ (5. GIS egység), melyet néhol durva aleurolit és finomhomokkő sorozatok váltanak fel. Az egység 5 alegységre osztható. Az 5/a alegységben finomhomokos apróhomokkő szaggatott ferde rétegződésű sorozata jelenik meg, melyet helyenként kúszóhullámos rétegződés tagol. A réteglemezek anyaga szenesedett növényi törmelék, csillám és agyagmárga. Az 5/b alegység durva aleurolitos anyagában ferde rétegződésü homokkő tagok is megjelennek. Az $5 / c$ alegység 2,77 méter vastagságban homogén, szerkezet nélküli, tömött apróhomokkő, melyben intraklasztok jelennek meg. Ez alatt sík párhuzamos, helyenként hullámos rétegződés építi fel. Az 5/d alegység durva aleurolit és finomhomokkő váltakozása 0,21 m vastagságban, melyben két helyen agyagmárga betelepülést találunk, melynek elválási felületén kagylóhéjmaradványok jelennek meg. Az 5/e alegységben megjelennek a kaotikusan gyürt réteglemezek, és jellemzője, hogy az alatta lévő egységre eróziós felszínnel települt. Szintén 5 alegységre osztható a 4. GIS egység, melyet agyagmárga, aleurolit és homokkő rétegek váltakozó sorozata építi fel, benne több helyütt jelennek meg bioturbált részek, szenesedett növényi törmelékek, csillámzsinórok, lángszerkezetek, valamint suvadás miatti konvolút rétegződés. A 3. GIS egység üledéke olyan szürke színü finom és apróhomokkő, melynek alsó része hullámos sorozathatárok közötti ferde rétegződésü, és amelyre szenesagyag rétegekkel megszakított finomhomokkő települ. Jellemző a csuszamlásos, suvadásos szerkezetek jelenléte. E fölött, a 2. GIS egységet 0,40 m vastagságban felhalmozódott sötétszürke színü agyagmárga és szenesagyag alkotja, melyet végül 0,3 méter vastagságban szürke színű, helyenként csillámos finom aleurolit zár (1.GIS egység).

\subsection{2. számú fúrás rétegsorának jellemzése}

A rétegsor 9 GIS egységre tagolható. Az üledékes rétegsor 16,3 méter PT alatti mélységben (9. felhalmozódási egység) szürke színű finomhomokos apróhomokkővel kezdődik. Az egység 5 alegységre osztható. Többnyire homogén, szerkezet nélküli, de kiékelődő sorozathatárok közötti ferde rétegződés, helyenként sík párhuzamos rétegződés, és szenesedett növénymaradványok, csillámzsinór réteglemez-kötegek is előfordulnak. A 8. GIS egységben világosszürke színü, laza apróhomokkő látszik, mely inverz gradációt mutat. A magrész alján ferde és szaggatott hullámos rétegződés jelenik meg. A következő felhalmozódási egységben 0,14 m vastagságban fekete színű, leveles szerkezetű szenesagyag réteg jelenik meg (7. GIS egység), melyre 1,22 m vastagságban sötétszürke színủ, leveles elválású agyagmárga és finom aleurolit települt (6. GIS egység). Az 5. GIS egység 2,35 m vastagságban felhalmozódott homokkő, durva és finom aleurolit, valamint agyagmárga 
váltakozásából álló sorozata. Az apróhomokkő csillámos, laza, homogén. Ez az egység is 5 alegységre osztható. A rétegsor 4. GIS egységének 0,45 m vastagságú üledékei az 5. genetikai egység üledékeihez hasonlóak, de ebben az egységben a homokköves betelepülések kisebb vastagságúak, mint az 5. genetikai egység esetében. Felső részén az első alegységben sík párhuzamos, majd ferde rétegződésű egységeket találunk. A második alegységben szenesedett növényi törmelék és agyagmárga réteglemezei alkotnak sík párhuzamos rétegződést. Erre sötétszürke finom aleurolit települt (3. GIS egység), 0,46 m méter vastagságban. A 2. GIS egységben sötétebb szürke színủ durva aleurolit alkot sík párhuzamos rétegződést szenesedett növényi törmelékekkel és csillámmal. A magrész alján alulról felfelé durvuló ritmusokat találunk. Felső részén gyüredezett rétegek látszanak. Szürke színü finom és apróhomokkő alkotja az 1. GIS egységet, mely erősen csillámos és nagy mennyiségü szenesedett növényi törmeléket tartalmaz. Alsó 0,1 méterében szerkezet nélküli, majd sík párhuzamos, és szaggatott sorozathatárok közötti hullámos rétegződés jelenik meg. A rétegekben néhol ferde tengelyü növényi szárak is látszanak.

\subsection{A 3. számú fúrás rétegsorának jellemzése}

$\mathrm{Az}$ üledékes rétegsor, mely 16 GIS egységre tagolható, aleurolit és agyagmárga intraklasztokat tartalmazó világosszürke apróhomokkővel kezdődik (16. GIS). A homokkő erősen csillámos, jól osztályozott, szemcseméretét tekintve homogén. Az egység vastagsága mintegy 4,5 méter. Az egységben ferde rétegződésü és szerkezet nélküli homokkő sorozatok váltakoznak. A szerkezet nélküli homokkőben gyakoriak az aleurolit intraklasztok. Az egységen belül 3 ciklusban normál gradáció jelenik meg. Az erre települő egységet (15. GIS) világosszürke finom- és sötétebb szürke durva aleurolit, valamint sötétszürke agyagmárga alkotja sík párhuzamos rétegződésben. Erre 0,05 m vastagságban világosszürke apróhomokkő települ (14. GIS), mely hullámos sorozathatárok közötti ferde rétegződést mutat. A réteglapokon szenesedett növényi törmelékek és csillám jelenik meg. Fölötte finom és durva aleurolit váltakozva települ sík párhuzamos rétegződésben (13. GIS). Az egység vastagsága $0,15 \mathrm{~m}$, ezen belül a sorozat 2 ciklusban felfelé finomodó szemcsemérettel jellemezhető. A permeábilis tető alatt 7,5-8,5 méter között (12. GIS) a 14. felhalmozódási egység üledékei ismétlődnek, rétegvastagsága $0,12 \mathrm{~m}$. A 11 . GIS $1,10 \mathrm{~m}$ vastagságban felhalmozódott sötétszürke durva aleurolit és világosszürke finom homokkő váltakozásából áll, melyben a durva aleurolit a domináns. Az egység jellegzetesen bioturbált, réteges elválású. A sorozatban a szemcseméret felfelé durvul, ezen belül 3 alciklus azonosítható. Aleurolitos üledékeit 0,33 m méter vastagságban felhalmozódott apróhomokkő váltja fel (10. GIS), mely világosszürke színü, ferde rétegződést mutat, a rétegek dőlésének foka 10-15 fok közötti, mely lefelé 
haladva csökken. Az apróhomokköre 1,07 m vastagságban a 9. GIS sötétebb szürke színü finom aleurolit és sötétszürke színű agyagmárga, valamint finomszemű homok váltakozásából álló, bioturbált, valamikor sík párhuzamosan rétegzett sorozat települt, melyben gyakoriak a terheléses szerkezetek. Többnyire a homokkő dominál az egységben. Ehhez hasonló jellemzőkkel a 8 . GIS- ben is finom és durva aleurolit települt $0,07 \mathrm{~m}$ vastagságban, azonban ebben a magrészben a finom homokkő alárendelten jelenik meg, inkább az agyagmárga és a finom aleurolit a domináns. A rátelepült 7. GIS ismét apróhomokkő, melyben suvadásból származó agyagmárga és aleurolit intraklasztok jelennek meg. A suvadt rétegek dőlése körülbelül 25 fok. Erre az egységre 0,23 m vastag finom aleurolit következik (6. GIS), amely alul durva aleurolittal sík párhuzamosan rétegzett, felső részén viszont homogén, réteglapjain szenesedett növénymaradványos. Az 5. GIS világosszürke színü, ferde rétegződésü finom- és apróhomokkő sorozataiban a réteglemezek anyaga aleurolit és agyagmárga. A felfelé finomodó szemcseméretű sorozat eróziós felszínnel települt az alatta lévő, 0,56 m vastag, finom- és durva aleurolit, agyagmárga alkotta egységre (4. GIS), mely erősen bioturbált csakúgy, mint. a 3. GIS-t 0,29 m vastagságban váltakozva felépítő finom és durva aleurolit maximum 2-3 centiméteres rétegei. E fölött (2. GIS) 0,36 m vastag finom és durva aleurolittal váltakozó finom homokkő jelenik meg. Alsó 0,1 méterében kiékelődő sorozathatárok közötti ferde rétegződést mutat, felette bioturbált. A 3. genetikai egység üledékeihez hasonlóan az 1. GIS üledékei finom és durva aleurolitok váltakozásából állnak maximum 2-3 cm-es erősen bioturbált rétegekkel.

\subsection{A 4. számú fúrás rétegsorának jellemzése}

A rétegsor 20 kisebb GIS egysége 9 nagyobb GSS egységre tagolható, melyek felosztását a könnyebb áttekinthetőség érdekében csak az 5.4. fejezetben mutatom be. Jelen alfejezet célja a GIS egységek bemutatása.

A PT alatti 25,5 méteres mélységben agyagmárga, finom aleurolit és finom homokkő ciklikus váltakozásával kezdődik (20. GIS), melyben a ciklusok alulról felfelé finomodnak. Kezdő tagjuk minden esetben finomhomokkő, mely aleuroliton keresztül agyagmárgába megy át. Alsó 1 méterében a homokos szakaszok vastagsága és gyakorisága nő, ezt követően 1 méteren keresztül csökken. A magrészt vetők tagolják. Az elvetési magasság $0.5-2 \mathrm{~cm}$ közötti, a dőlés kb. 71 fok. Erre szerkezet nélküli finomhomokos apróhomokkő települt (19. GIS).

A 18. GIS gyakran bioturbált, agyagmárga, finom és durva aleurolit váltakozásával indul és néhol szenesagyag betelepülést is tartalmaz. A 17. GIS-ben $10 \mathrm{~cm}$ vastag sötétszürke színű szenes agyag is megjelenik, melyre $0.6 \mathrm{~m}$ bioturbált finom aleurolit és agyagmárga 
települt (16. GIS). A 15. GIS egység a 16.-ra eróziós felszínnel települt világosszürke színü, döntően flázeres rétegződésü, összeolvadási felszínekkel és agyagmárga betelepülésekkel tagolt finomhomokos apróhomokkő, melyben párhuzamos sorozathatárok közötti ferde rétegződés is megjelenik, azonban a réteglemezek nem folytonosak.

A finom aleurolit és agyagmárga váltakozásával kezdődő 14. GIS egység (PT alatt 13,77,5 m,), apró- középszemcsés homokkőre vált a 13. GIS egységben, mely párhuzamos sorozathatárok közötti ferde rétegződést mutat, réteglemezeinek anyaga szenesedett növényi törmelék és csillám. Felette $20 \mathrm{~cm}$ vastag szenes agyag betelepülést találunk. Az egységre a finom és durva aleurolit váltakozása is jellemző.

Az 1. magrész kezdő tagjaként (12. GIS) erre az üledékre világosszürke színü finomhomokkő települt, melyben $70-80$ fokos dőlésszögü tektonikai síkra emlékeztető geometriájú törési sík látható, fölötte a 11. GIS egység homogén sötétszürke színű finom aleurolitja, majd a leveles elválású szenesagyag (10. GIS) települt. Záró sorozata egy 2,3 m vastag finom aleurolit és agyagmárga váltakozásából álló egység.

A 9. GIS még a PT alatt agyagmárga, finom aleurolit és finom homokkő váltakozásából álló rétegekkel indul azonban erre, már a PT fölött települt 8.GIS, majd a 7. GIS 3,35 m vastagságban kifejlődött világosszürke színü finomhomokos apróhomokköve települt. A magrészben gyakoriak az összeolvadási felszínek, a kiékelődő sorozathatárok közötti ferde rétegződés, a felső áramlási rezsim sík párhuzamos rétegződése, mely több ütemben képződött.

A 6. GIS-ben, mely már a PT fölött található, alul sötétszürke, fekete, magas szerves anyag tartalmú agyagmárga és szenes agyag települt. Előbbiben szabálytalan alakú, 1-2 centiméteres karbonátos konkréciók láthatók. Az 5. GIS egység alul sík párhuzamos, felül lencsés rétegződésű agyagmárga.

Az előző egységre eróziós felszínnel települő (4. GIS) világosszürke finom homokkő, mely alul kiékelődő sorozathatárok közötti ferde rétegződésű, felül flázeresen rétegzett. A 3. GIS agyagmárga és finom aleurolit váltakozásából áll, mely bioturbált, terheléses szerkezetekkel, suvadt finomhomokkővel tagolt.

A 2. GIS a PT fölött 7,38 méterrel kezdődik. Világosszürke színü, sok 1-2 cm-es agyagmárga réteg tagolja. Jellemzően sík párhuzamos, kis dőlésü párhuzamos sorozat határok közötti ferde rétegződést mutat, de kis vastagságban $(10-15 \mathrm{~cm})$ kiékelődő sorozathatárok közötti ferde rétegződés is megjelenik. A réteglemezek anyagában szenesedett növényi törmelék és csillám gyakori. A rétegsort záró 1. GIS)-t sötétszürke színü, földes törésű agyagmárga alkotja, melyben sok homoklencse is található. 


\section{5. Üledékfáciesek definiálása}

$\mathrm{Az}$ adott fúráspontban az egyes genetikai egységek térbeli kiterjeszthetőségét a permeábilis tetővel párhuzamos metszetsíkokon térképezett homoktartalom térképek segítségével vizsgálhatjuk. Ehhez szükséges a magfúrás vertikális sorozatainak ismerete, melynek célja a kőzetoszlopon belül a genetikai értelemben összetartozó egységek, alegységek azonosítása. Az üledékfácies megjelölése az üledékszerkezeti jegyek és az egyes kőzettípusok genetikai szempontú értékelésén alapszik.

\subsection{Az 1. sz fúrás jellegzetes üledékfáciesei}

A szedimentológiai magleírás a rétegsoron belül 7 GIS-t különített el. A 7 GIS egység 5 nagyobb egységre, GSS-re osztható, melyek az alábbiak szerint alakulnak (5-1. ábra):

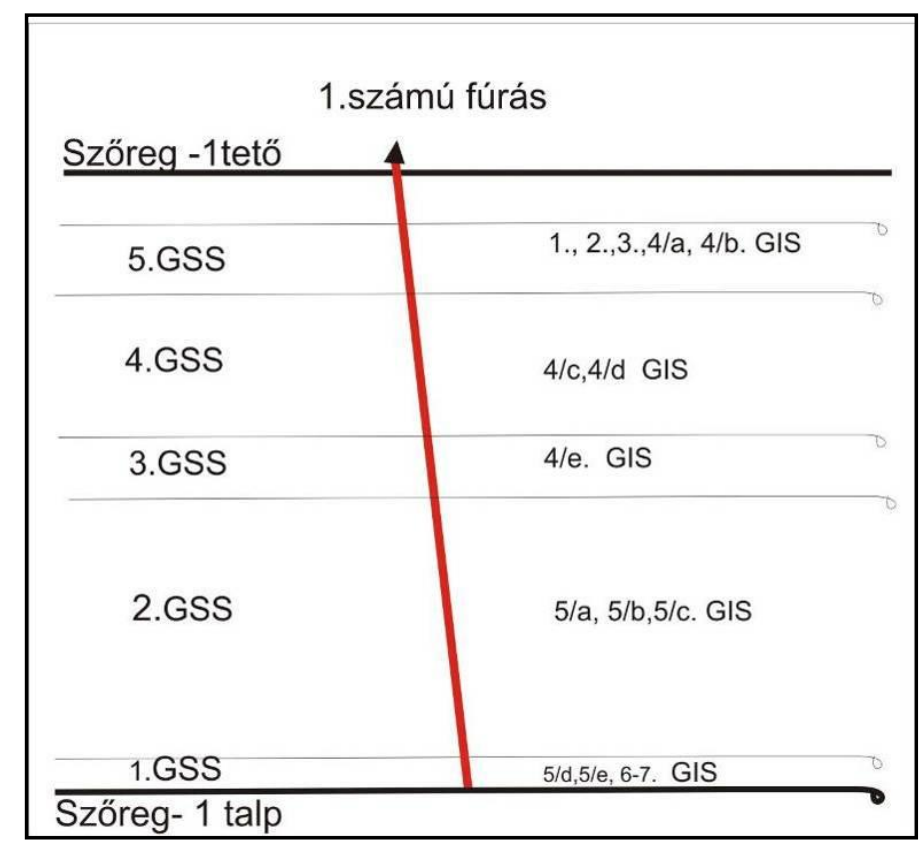

5-1. ábra Az 1. sz. fúrás szedimentológiai, genetikai tagolása

Az 1. számú magfúrás a telepet 16,5 méter vastagságban harántolta. A szedimentológiai rétegsor alapján a fúrás öt rétegtani sorozata:

1. V. GSS: PT alatt 3,07 métertől a PT alatt 5,35 méterig

2. IV. GSS: PT alatt 5,35 métertől a PT alatt 9,05 méterig

3. III. GSS: PT alatt 9,05 métertől a PT alatt 9,99 méterig

4. II. GSS: PT alatt 9,99 métertől a PT alatt 17,62 méterig

5. I.. GSS: PT alatt 17,62 métertől PT alatt 19,5 méterig

Az 1 sz. fúrás öt rétegtani sorozatát kialakító üledékes környezetek és alkörnyezetek üledékes fáciesei: meder-és természetes partgát együttes $(1) \rightarrow$ elosztó meder $\rightarrow$ 


\section{mederfelhagyás $\rightarrow$ mederáttörés és mederfelhagyás $\rightarrow$ meder-és természetes partgát együttes (2).}

A meder-természetes partgát együttes (1) üledéksora (I. GSS) az 5/d, 5/e, 6. és 7. GIS egységet foglalja magában. Az 5e. GIS az alatta lévő 6. GIS egység agyagmárgáját és finom aleurolitját erodálva települt. Az egység finom apróhomokkővel indul, melyben áramló vízből letelepült hullámos rétegződés jelenik meg. Az apró homokkőben aleurolit-agyag, valamint szenes agyag intraklasztok láthatók, melyek az áramló víz korábbi aljzatot, vagy partfalat erodáló tevékenységére utalnak. A szenes agyag jelenléte partközeli, korábban nyugodtvízi, vegetációban gazdag helyzetet tükröz, melyet az erősödő áramlás később erodált.

A finomhomokkőre települt finom és durva aleurolit- agyagmárga vékony rétegződése alsó áramlási rezsimben, áramlásoktól mentes, vagy gyenge áramlásokkal jellemezhető környezetben való letelepülést mutat. Erre agyagmárga és finom aleurolit suvadásos szerkezete települt 0,74 méter vastagságban, mely továbbra is csak gyengébb áramlásoktól háborgatott környezetre enged következtetni, jellemzően lejtős térszínen, ahol az üledékek suvadásra, csúszásra hajlamosak. Ilyen alkörnyezet a folyóvízi területeken a víz alatti partgát oldala.

A természetes partgát üledékére eróziós felszínnel települő finom és apróhomokkő, illetve durva aleurolit kaotikusan gyürt szerkezete a természetes partgát időszakos, áramlások alá kerülését mutatja. A helyenként vékony laminákban közbetelepülő agyagmárga a partközelben, áramlásoktól kevésbé háborgatott környezetben halmozódott fel.

A rétegsor alapján egy medrét időnként változtató, víz alatti partgátját építö, és romboló, dinamikus meder képe rajzolódik ki.

Az elosztó meder üledékfáciese (II. GSS) az 5/a., 5/b. és 5/c. GIS egységet foglalja magában. A fácies a permeábilis tető alatt 17,62 méter mélységben kezdődik, és 9,99 méterrel a tető alatt ér véget. Az 5c. egység 5,69 méter vastagságban felhalmozódott apró homokkőből áll. Az I.GSS-re az alsó 15 centiméterben hullámos, szaggatott hullámos rétegződéssel települ, amely sík párhuzamos rétegződésbe megy át, végül felső 2,77 métere homogén, szerkezet nélküli, néhol aleurolit intraklasztokkal. A felső áramlási rezsim sík párhuzamos rétegződése és a tömött homokkő egysége egy stabil, kiépült elosztó medret jelez nagy energiájú szállító közeggel, mely a korábbi aljzatból diszkosz alakú intraklasztokat szakított fel, majd osztályozatlan üledékében kiülepítette a szállítási energia csökkenésével.

Ezt támasztja alá az apróhomokkőre települt durva aleurolit és finomhomokos apróhomokkő is (5/b., 5/a.), mely szaggatott, néhol kúszóhullámos rétegződésével az áramló közeg sebességének csökkenését mutatja. A szenesedett növényi törmeléket, csillámot és agyagmárgát tartalmazó réteglemezek dús vegetációjú forrásterületet, partközelséget jeleznek. 
A mederfelhagyás (III. GSS) a 4/e. GIS 0,94 méter vastagságú üledékeit tartalmazza. A korábbi meder felhagyását egyértelműen jelzik az elnyelődött finomhomokkő és durva aleurolit anyagú hullámok, valamint az üledékek bioturbált jellege, mely kis vízborítású, pangóvizes környezetet feltételez.

A IV. GSS-ben mederáttörés, majd ismételt mederfelhagyás üledékeit találjuk. A mederáttörést jelzi a 2,48 méter vastagságban kifejlődött finom homokkő, mely finom- és durva aleurolit rétegekkel váltakozik. Benne lángszerkezeteket is megfigyelhetünk. A meder felhagyását a szállítási energia csökkenését jelzik az ismét megjelenő elnyelődött durva aleurolit és finomhomokkő hullámok, a bioturbáció, valamint az egység fokozatos átmenete agyagmárgába. A felhagyási időszakban alsó áramlási rezsimben felhalmozódott sötét színü, szenesedett növényi törmeléket és csillámzsinórokat tartalmazó sík párhuzamos rétegződésü durva aleurolit települt.

A területen újra aktívvá váló, vagy új meder jelenlétét bizonyítja az V. GSS alján megjelenő laza, szerkezet nélküli, néhol aleurolit és agyagmárga intraklasztokat tartalmazó apróhomokkő. Az V. GSS-ben váltakozva települt homokkő és agyagmárga sorozatok a meder- természetes partgát együttes kifejlődésére utalnak. A finomszemü aleurolit és agyagmárga, finom és apróhomokkő rétegződésére jellemző a suvadásos, konvolút, kaotikus, erősen gyüredezett jelleg, a finom és apróhomokkövekre pedig a hullámos sorozathatárok közötti ferde rétegződés.

$\mathrm{Az}$ 1. sz. fúrás rétegsorának, üledékfácieseinek elméleti modelljét az 5-2. ábra szemlélteti. 


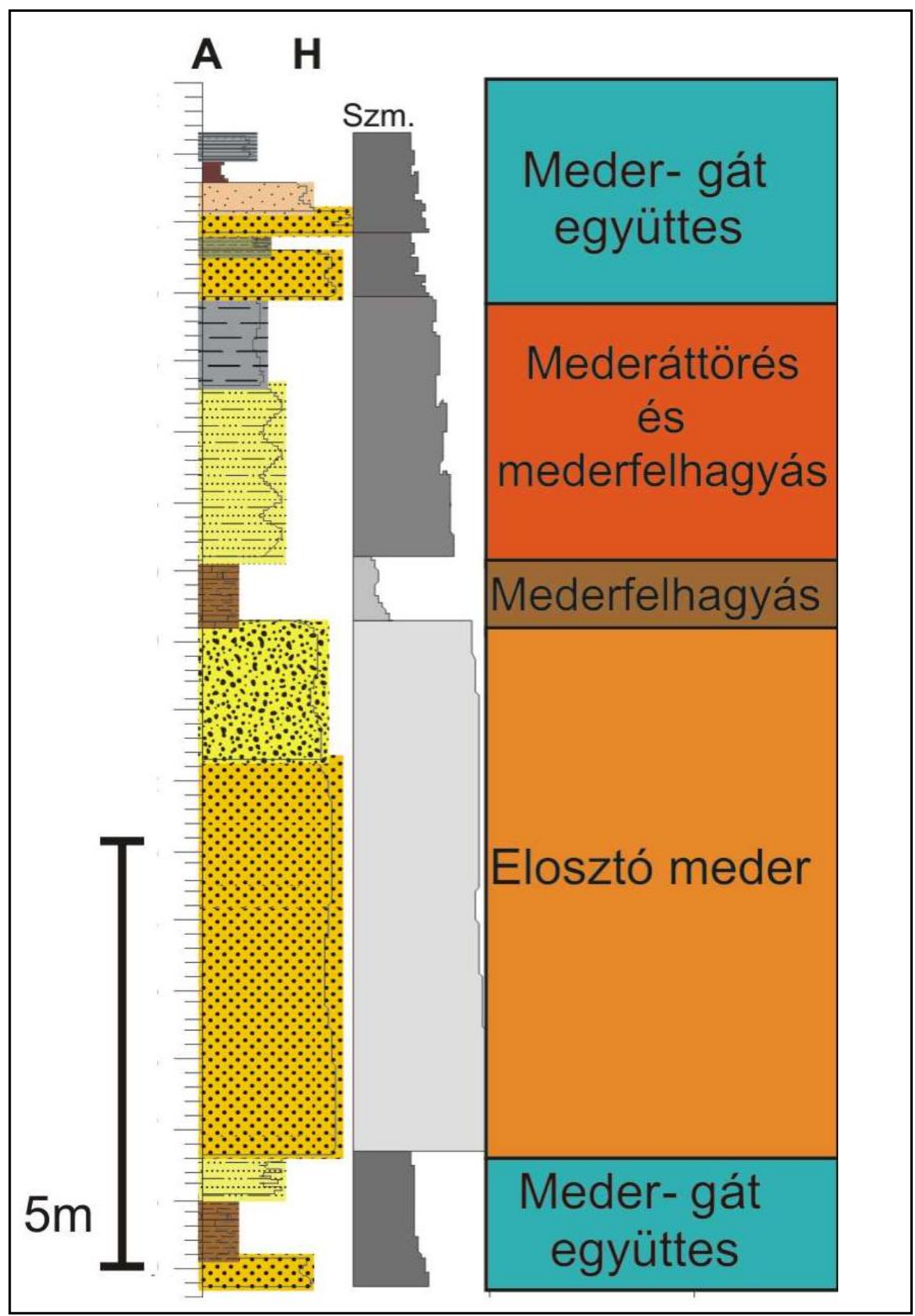

5-2. ábra Az 1. sz fúrás rétegsora és üledékfáciesei ( Geiger J.-. Sebök Sz., 2008) 


\subsubsection{Fejlődésmenet}

A rétegsor egy meder-természetes partgát komplex $\rightarrow$ elosztó meder $\rightarrow$ mederfelhagyás $\rightarrow$ mederáttörés és mederfelhagyás $\rightarrow$ meder-természetes partgát komplex átmenet üledékeit tárta fel. A rétegsor egy meder és természetes partgát víz alatti részének üledékeivel kezdődik. A természetes partgát üledékei finom- és durvaszemü aleurit és finomhomokos aleurit, melyre finomszemü aleurittal rétegzett finomszemü homok települt, jelezve a terület gyenge áramlásoktól bolygatott helyzetét. Az üledékfácies térbeli kiterjesztését a homoktartalom térképek tekintetében vizsgálva, a folyamatot jól illusztrálják az egyes metszeti térképek. A permeábilis tető alatt 20 méterrel a fúrás az északi hordalékelosztó-rendszerből táplálkozó, keskenyebb hordalékelosztó meder frontvonalában helyezkedik el ( 5-3. ábra, A.).

Ezeket az üledékeket erodálva, a területen egy állandósuló elosztó meder által felhalmozott finomhomokos apróhomokkő települt. Az ebben megjelenő felső áramlási rezsimű sík párhuzamos rétegződés és a kúszóhullámos rétegződés jelzik a szállítási energia jelentős nagyságát is. A permeábilis tető alatt 19 méterrel a fúráspontban és környezetében a homoktartalom 80-90\%-ra nő, és a hordalékelosztó meder korábbi helyzetéhez képest nagyobb kiterjedést ér el (5-3. ábra, B).

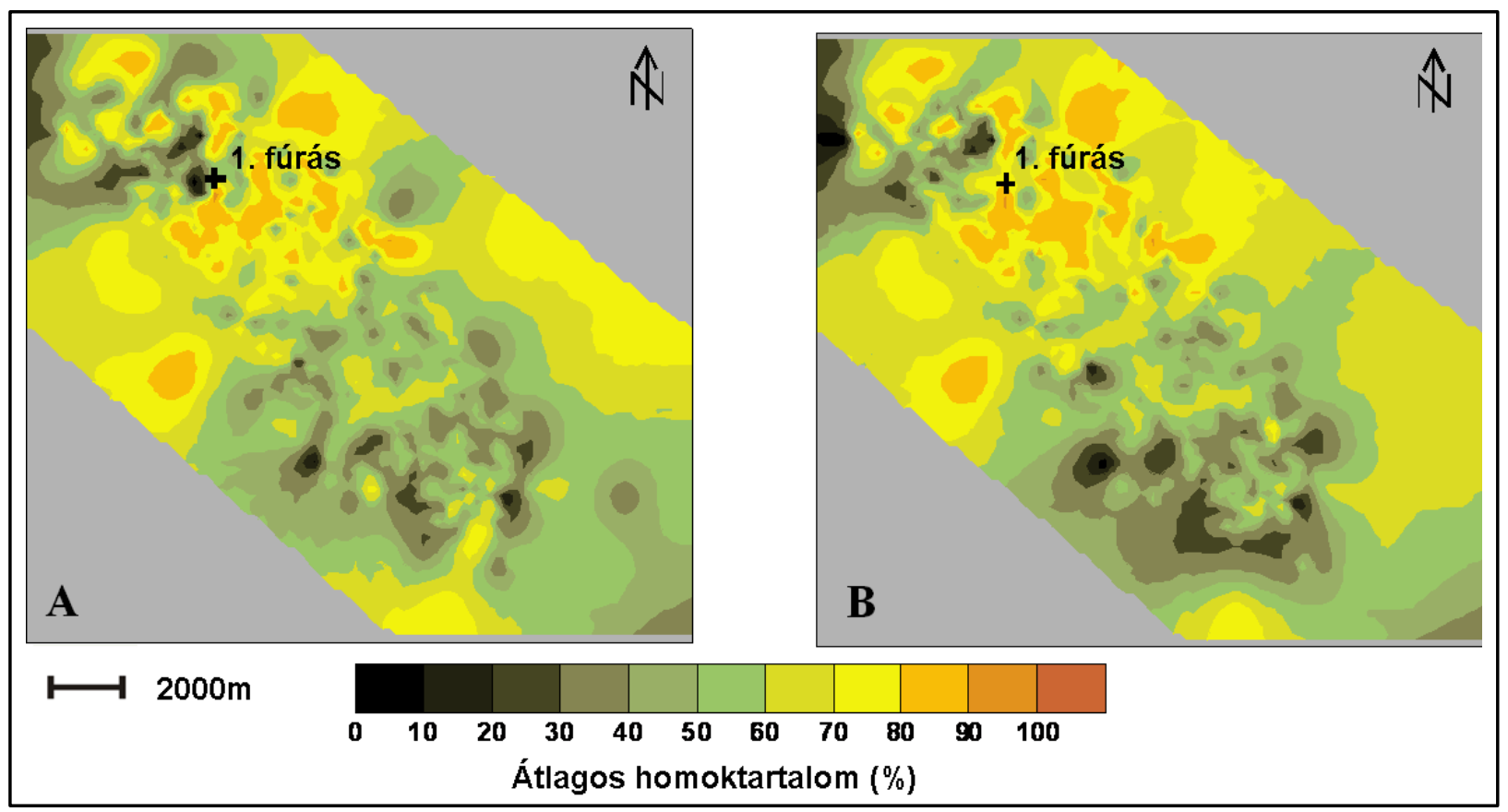

5-3. ábra Homoktartalom a permeábilis tető alatt 20 (A) és 19 (B) méterrel

A maximális kiterjedését a permeábilis tető alatt 15,5 méterrel éri el. Ezután a terület elgátolódik. Ezt a rétegsorban rá települő agyagmárga és finom illetve durva aleurit 
váltakozása jelzi, mely a pangóvízi környezetekre jellemző bioturbált, elnyelődött finomhomokkő- durva aleurit hullámokat is tartalmaz.

Az üledékképződés a területen nem folytatódhatott zavartalanul, mert az előző üledékekre települő laza, szerkezet nélküli apróhomokkő intraklasztokkal egy újabb, a területre betörő lineáris áramló közeget jelez. Ez valószínűsíthetően az ÉK-i rendszer irányából tört be az elgátolt területre. A meder fácies klasszikus rétegsora nem fejlődhetett ki, mivel újabb mederfelhagyás következett, így a terület elgátolódása következményeként az üledékekre ismét agyagmárga és aleurit települt. Az üledékekben megjelenő suvadás miatt kialakult konvolút rétegződés a partfal illetve természetes partgát közelségét jelzi. Továbbiakban a területen megélénkülö, irányát többször változtató, finom és apróhomokkövet lerakó elosztómeder jelenléte valószínü, melynek üledékeit a természetes partgát üledékei tagolják.

A fúrás egykori, lehetséges helyzetét az 5-4. ábra szemlélteti.

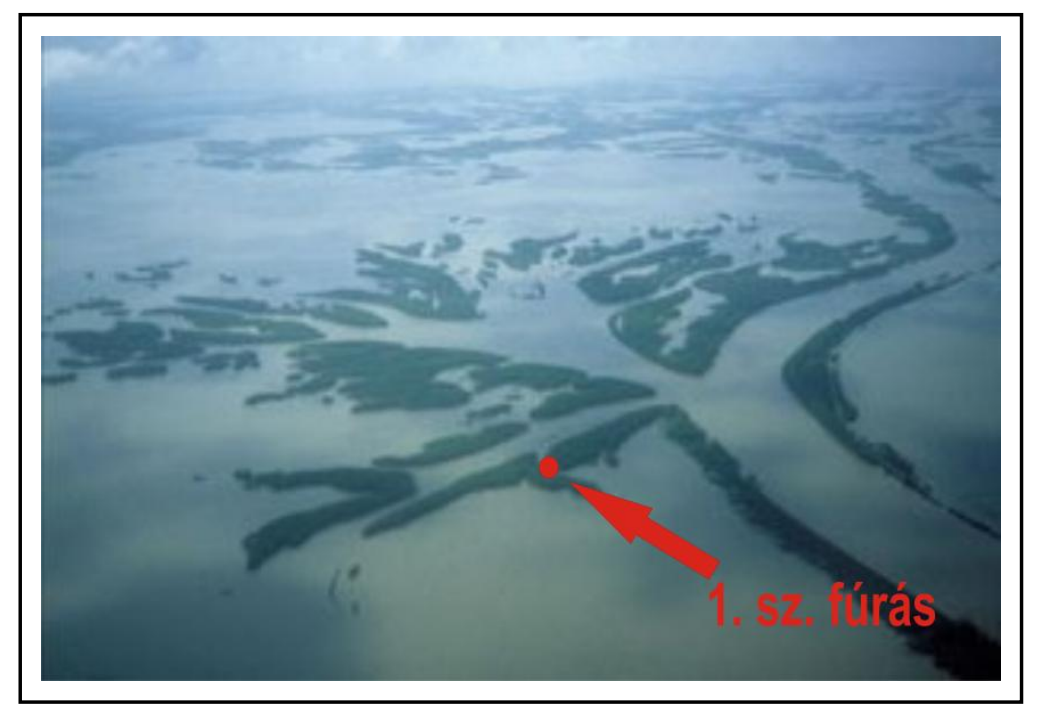

5-4. ábra Az 1.sz. fúrás elméleti, lehetséges múltbeli környezete a Mississippi folyó analógiája alapján (fotó: Törnqvist, T.E. 1993 ) 


\subsection{A 2. sz fúrás jellegzetes üledékfáciesei}

A szedimentológiai magleírás a rétegsoron belül 9 GIS egységet különített el. A 9 GIS 3 nagyobb GSS egységre osztható, melyek az alábbiak szerint alakulnak (5-5. ábra):

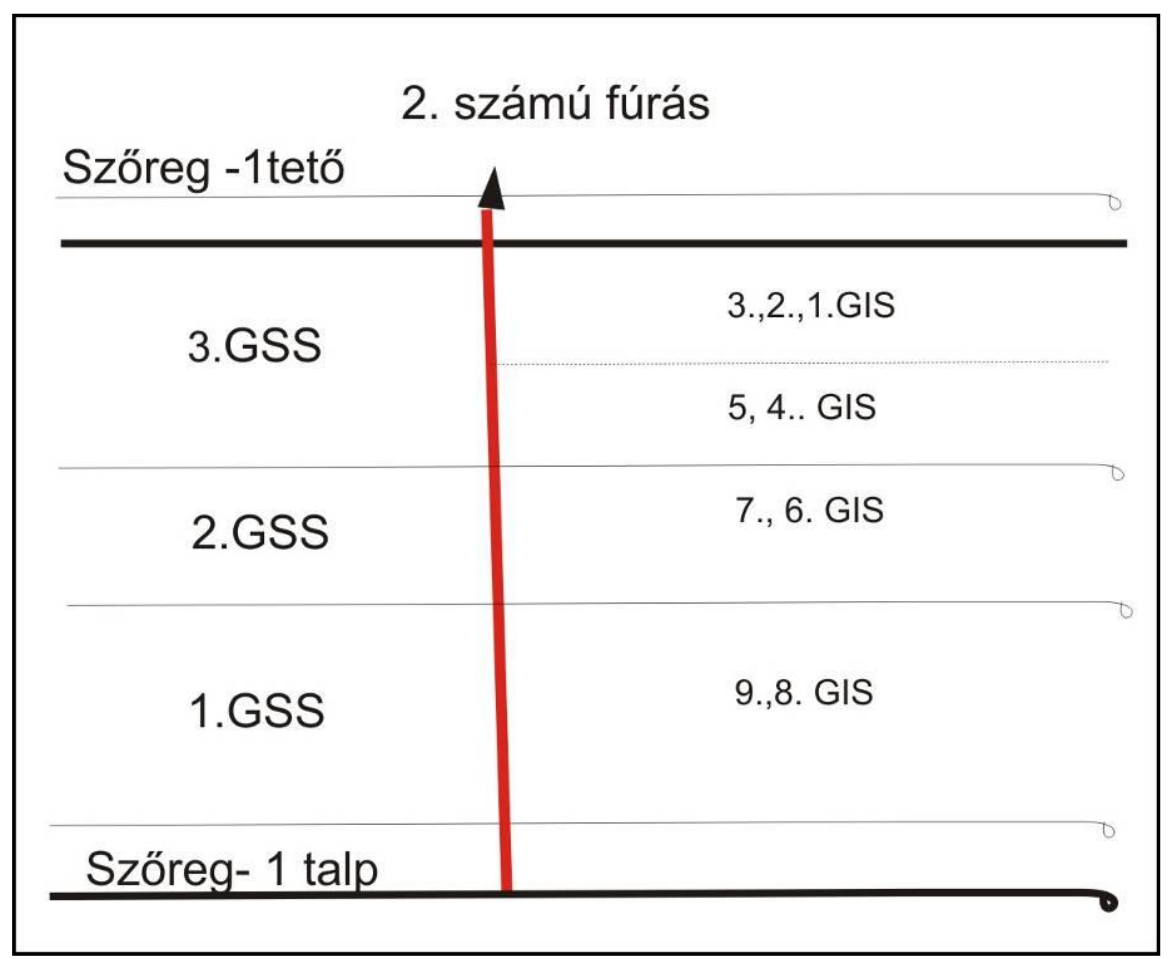

5-5. ábra A 2.sz. fúrás szedimentológiai, genetikai tagolása

A 2 sz. magfúrás a telepet 14,04 m vastagságban harántolta. A szedimentológiai rétegsor alapján a 2-es fúrás 3 GSS egysége:

- III. GSS: PT alatt 2,30 métertől a PT alatt 7,46 méterig;

- II. GSS: PT alatt 7,46 métertől a PT alatt 8,82 méterig;

- I. GSS: PT alatt 8,82 métertől a PT alatt 16,30 méterig tart.

A 2. számú fúrás 3 fácies környezetében és alkörnyezeteiben felhalmozódott üledékeinek rétegsorát jeleníti meg: crevasse channel $\rightarrow$ mocsár (illetve mocsári környezet gyenge áramlásokkal) $\rightarrow$ mederáttörési lóba átmenet.

Crevasse channel részleges elgátolódása, majd progradációját, ismételt gyors elgátolódással a 8-9. GIS üledéksora képviseli (I. GSS). A 9. GIS egységben a finomhomokos apróhomokkő többnyire homogén, szerkezet nélküli, de néhol sík, párhuzamos, vagy kiékelődő sorozathatárok közötti ferde rétegződésben jelenik meg. Szenesedett növényi törmeléket és csillámzsinórokat is tartalmaz. A szerkezet nélküli homokkő és a sík párhuzamos rétegződés a crevasse channel progradációját jelzik, míg a kiékelődő sorozathatárok közötti ferde rétegződés a korábbi áramlási irányok megváltozásáról 
tanúskodik, ami a részleges elgátolódáshoz vezethetett, és a rétegsorban agyagmárga felhalmozódását eredményezte. Az első részleges elgátolódást követően a 8 . genetikai egységben ismét egy fokozatos mederprogradáció veszi kezdetét alulról felfelé durvuló apróhomokkövet, majd sík párhuzamos, szaggatott sík párhuzamos, végül szerkezet nélküli homokkövet felhalmozva. A mederprogradáció ezen a ponton megtorpan, és a szenesagyag felhalmozódása veszi kezdetét a pangóvizes időszakban a II.GSS-hez tartozó 7. GIS egységben.

Mocsár fácies felhalmozódásait (II.GSS) a 6-7. GIS egységek tartalmazzák. Üledékei jellemzően fekete színü, leveles elválású szenes agyag, és leveles elválású agyagmárga, valamint finom aleurolit. Az egységen belül a szervesanyag tartalom lefelé nő, ami a fúráspont partközelségét, és az erózióbázis szervesanyag tartalmának időbeni, fokozatos kimerülését jelzi. A szó szoros értelmében vett mocsár fácies összvastagsága 1,34 méter.

Mederáttörési lóba két fázisban ( III. GSS egység) A III. GSS egység két felfelé durvuló szemcseméretű ciklusra osztható. Mindkét ciklus 1-1 mederáttörési lóba fáciesét képezi. Az első ciklust az 5. GIS üledéksora építi fel, mely egy finom és apróhomokkő, durva és finom aleurolit, valamint agyagmárga váltakozásából álló sorozat döntően homokkő túlsúllyal. A homokkő sík párhuzamos, és tömött, szerkezet nélküli formában jelenik meg, mely a mederáttörés folyamatát jól jellemzi. A mederáttörés energiaviszonyainak megfelelően az üledékes sorozat finomszemü üledékének megváltozásával kezdődik, melynek tetejére szerkezetnélküli, csillámos, laza apróhomokkő települt. Az 1. ciklus üledékeinek relatív vastagsága 2,35 méter. A két. ciklus az 1. ciklus sorozatához hasonló rétegekkel indul (4. GIS), de kevésbé homokos kifejlődésü. Szenesedett növényi törmelékeket is tartalmaz. Erre hasonlóan finom és durva aleurolit, finomhomokkő és agyagmárga váltakozó sorozata települt felső áramlási rezsimben kialakult sík párhuzamos rétegződéssel. A sorozat szerkezet nélküli, végül sík párhuzamos rétegződésű finom és apróhomokkővel zárul. Az apróhomokkőben helyenként ferde tengelyü növényi szárak is látszanak. A második mederáttörés a jellemzők alapján kisebb energiával mehetett végbe, és valószínűsíthető a vegetációban gazdag part közelsége.

$\mathrm{Az}$ 2. számú fúrás rétegsorának, üledékfácieseinek elméleti modelljét az 5-6. ábra szemlélteti. 


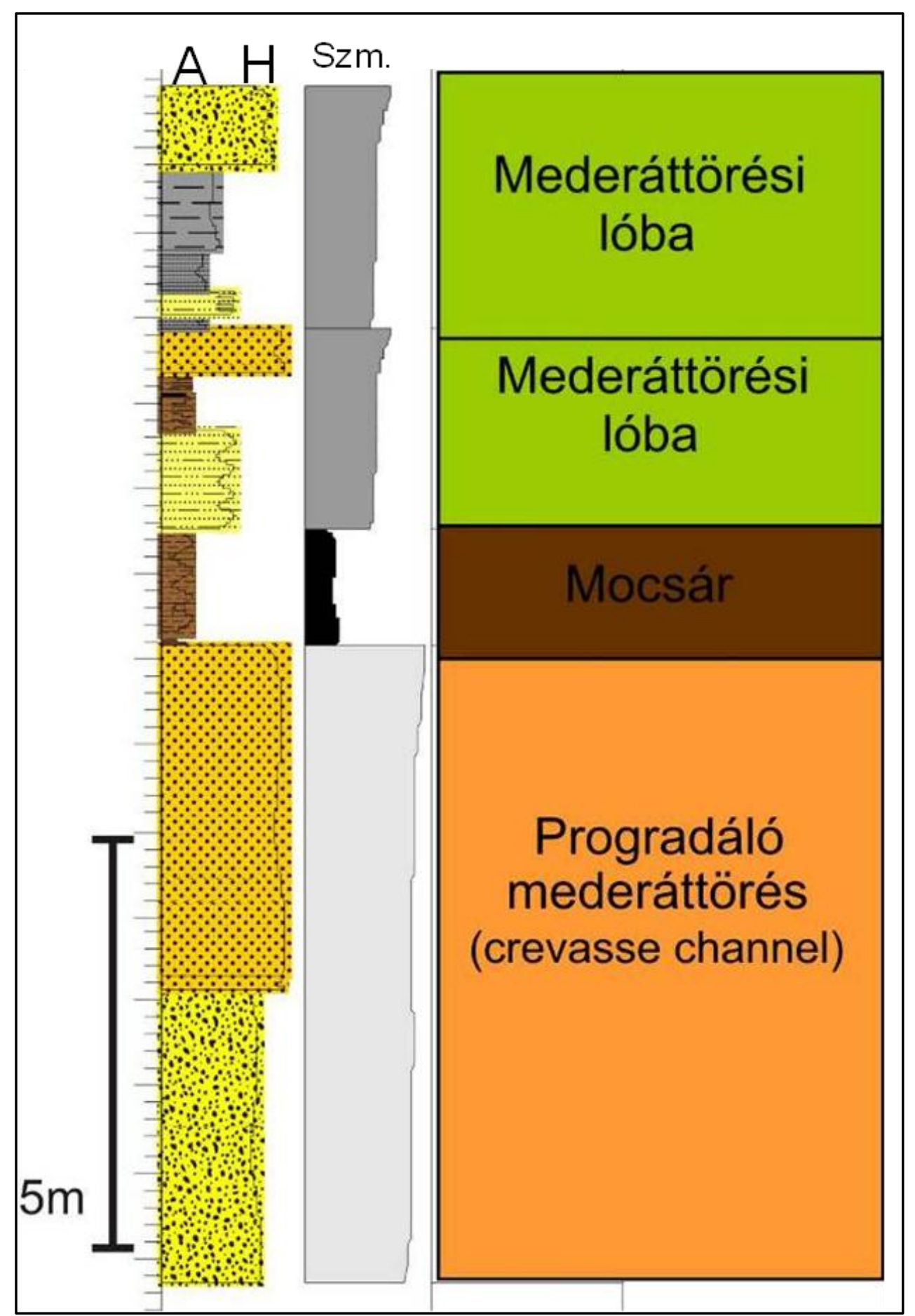

5-6. ábra 2 .számú magfúrás üledékfáciesei (Geiger J.-. Sebők Sz., 2008) 


\subsubsection{Fejlődésmenet}

A 2. számú. fúrás rétegsora egy crevasse channel (azaz mederáttörés)- mocsár- 2 fázisban kifejlődött mederáttörési lóba átmenet üledéksorát tárta fel. A permeábilis tető alatt 14,5 méterrel a fúrás és közvetlen környezete a térképezett terület középvonalában helyezkednek el (5-7. ábra), egy valószínüsíthetően É-ÉNy-i irányból terjeszkedő torkolati zátony-rendszerből D-re kiinduló crevasse channel nagy szállítási energiával jellemezhető területén. Itt az üledékek homoktartalma 80-90 \% között van.

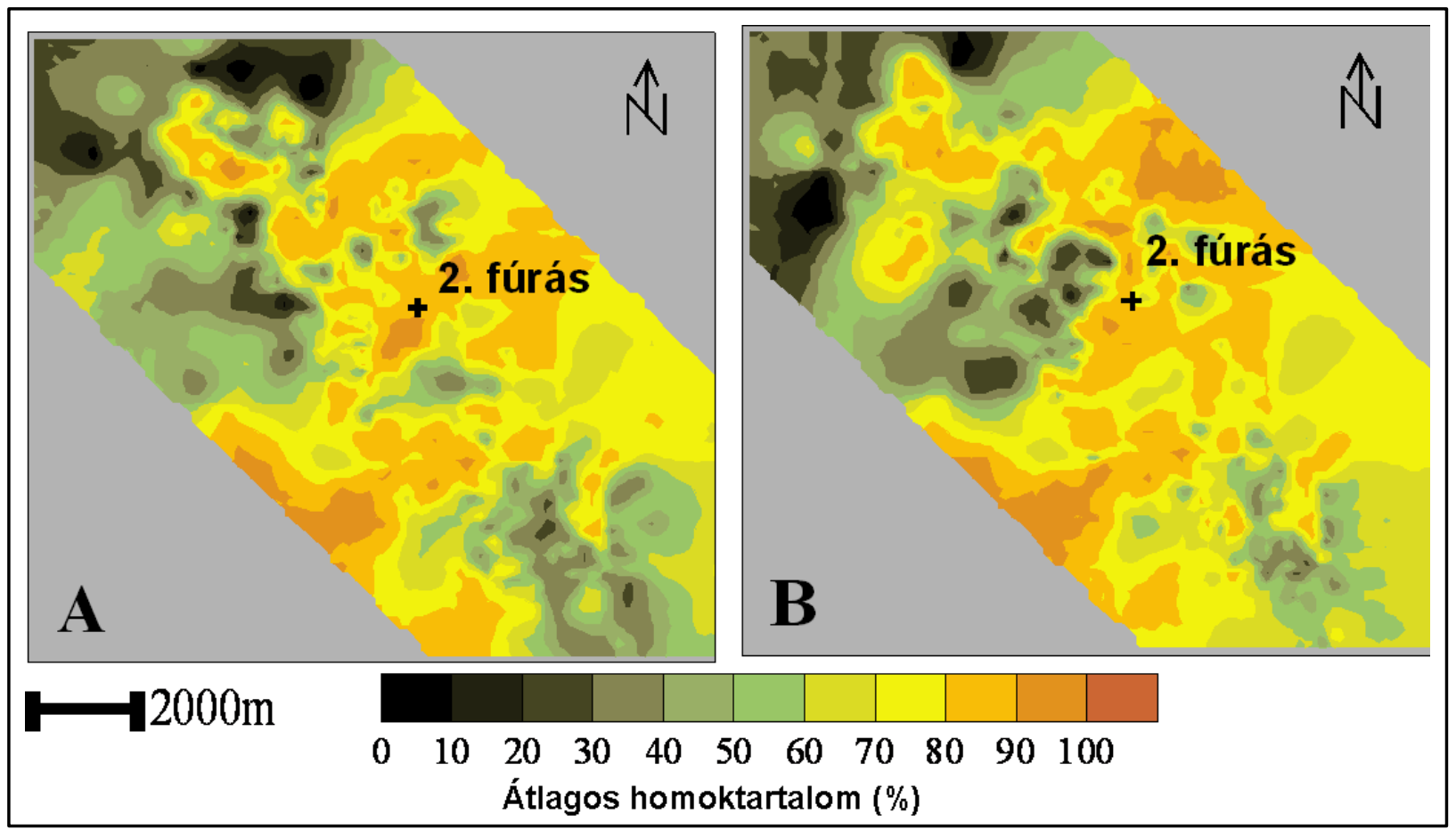

5-7. ábra Homoktartalom a permeábilis tető alatt 14,5 (A) és 12,5 (B) méterrel

A progradáció tovább folytatódik (5-8. ábra) egészen a permeábilis tető alatt 10,5 méter mélységig, amikor a terület részleges elgátolódása, a progradáció megszűnése látszik (5-9. ábra). A területen a finomszemü üledékek veszik át a nagy homoktartalmú üledékek helyét, de a fúrás még a meder nyugati szélén helyezkedik el, ahol ekkor is apróhomokköves üledékek települnek. A meder szélessége és hossza is erőteljesen lecsökken. 


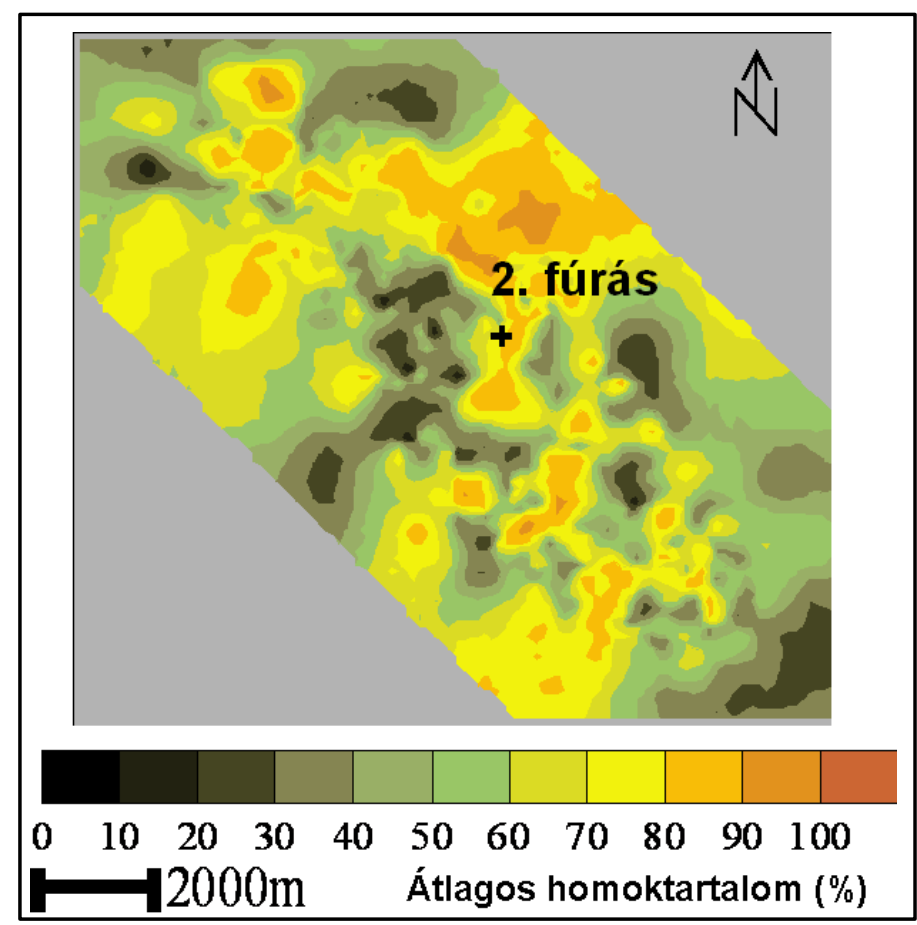

5-8. ábra A terület elgátolódása, a progradáció megszünése a permeábilis tető alatt 10,5 méterrel

Ezt követően a crevasse channel kiterjedése tovább csökken, a fúráspont területe egyre inkább kis vízmélységgel jellemezhető területre szorul ki. Ekkor települt üledékei döntően szenes agyag és leveles elválású agyagmárga, mely a terület elmocsarasodásáról, időszakos szárazulattá válásáról tanúskodik. A terület később két fázisban fokozatosan feltöltődik a zavartalan üledékképződést megszakító áramlások homokosabb üledékeivel. A feltöltődés második fázisában homokosabb üledékek települnek le, melyek a szállítási energia fokozatos növekedését jelzik.

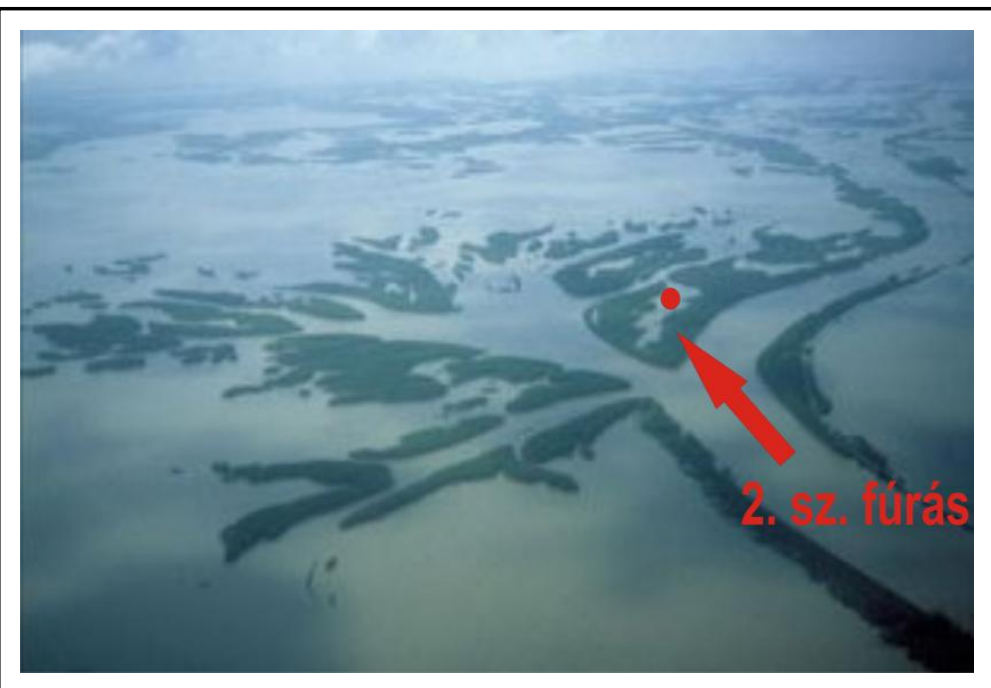

5-9. ábra A 2. számú fúrás elméleti lehetséges múltbeli helyzete a Mississippi folyó analógiája alapján (fotó: Törnquist, T.E. 1993) 


\subsection{A 3. számú. fúrás jellegzetes üledékfáciesei}

A 3. számú fúrás 9 méter vastagságban harántolta a Szőreg-1 telepet. A szedimentológiai magleírás a rétegsoron belül 16 GIS egységet különített el. A 16 GIS 3 nagyobb GSS egységre osztható, melyek az alábbiak szerint alakulnak (5-10. ábra):

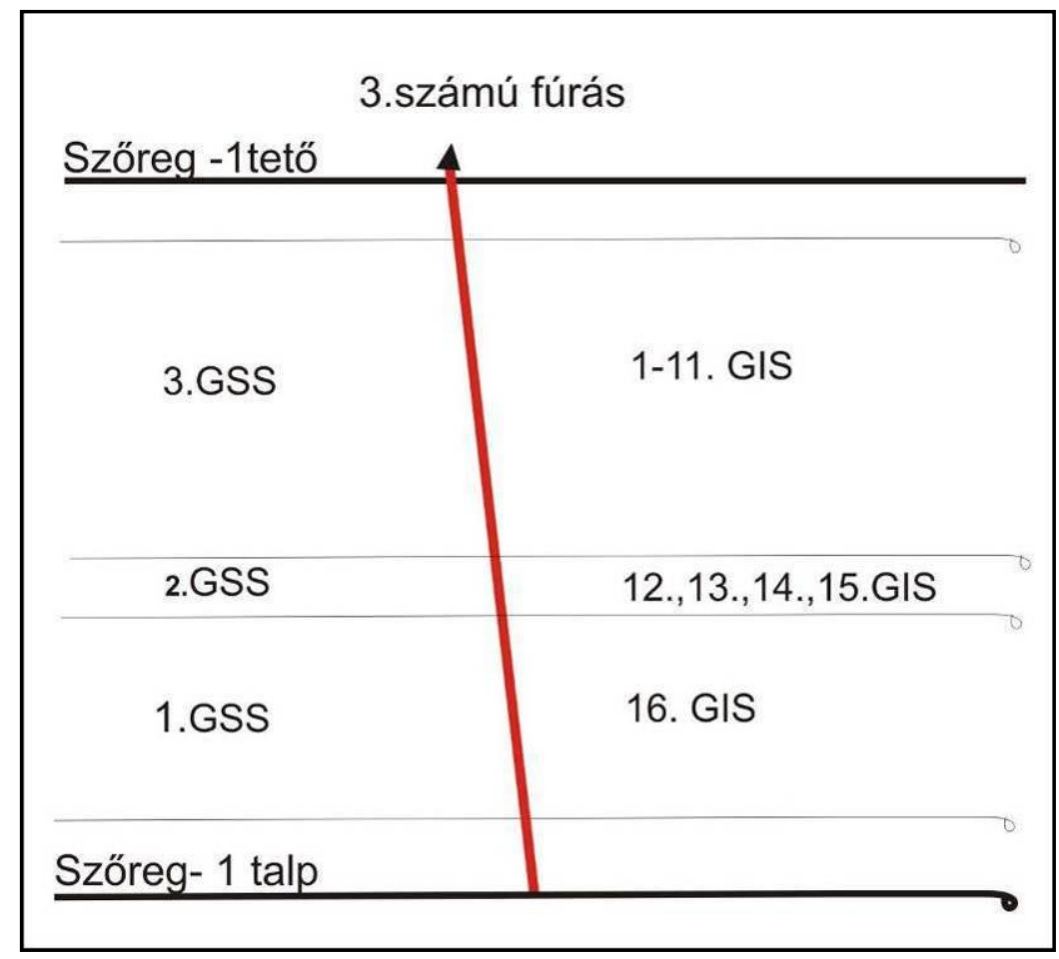

5-10. ábra A 3. számú fúrás szedimentológiai, genetikai tagolása

A 3 GSS egység mélységbeli megoszlása:

- III. GSS: PT alatt 4,00 métertől a PT alatt 8,50 méterig;

- II. GSS: PT alatt 8,50 métertől a PT alatt 10,00 méterig;

- I. GSS: PT alatt 10,00 métertől a PT alatt 13,00 méterig.

A 3. sz. fúrás 3 fácies környezeteiben felhalmozódott üledékeinek rétegsorát jeleníti meg: elosztó meder $\rightarrow$ meder és természetes partgát együttes $\rightarrow$ mederáttörési lóba kifejlődése 3 ciklusban.

Az elosztó meder üledéksora (III. GSS) a 16 GIS egységet foglalja magába. A 16. GIS sík párhuzamos vagy kis szögű ferde rétegződésű sorozattal indul, majd erre szerkezet nélküli apróhomokkő települ, melyben agyagmárga és aleurolit intraklasztok jelennek meg. A sík párhuzamos rétegződés erőteljes lineáris áramlásra utal, a szerkezet nélküli homokkő pedig olyan áramlásra, mely nagy szállítási energiával rendelkezett, és az energia hirtelen lecsökkenésével üledékét osztályozatlanul ülepítette le a szállítás közben a gyengén konszolidált finomszemü üledékek eróziójából származó intraklasztokkal együtt. Az üledék csillámtartalma magas. A 16. GIS- ben az intraklasztos szerkezet nélküli rétegeket néhol 
felfelé finomodó gradációval és sík párhuzamos rétegződéssel jellemezhető sorozatok váltják fel, ami tipikus folyóvízi meder környezetre utal.

Erre az egységre meder és természetes partgát együttes üledéksora, finom és durva aleurolitból és agyagmárgából álló egységek váltakozva települtek (15-12. GIS, II. GSS). A finom és durva aleurolitból és agyagmárgából álló egységek váltakozva települtek. A finom és durva aleurolit megjelenése az apróhomokkő rétegek között a szállító közeg energiájának fluktuációjára utal. Üledékszerkezeti jegyek tekintetében a sorozatot sík párhuzamos rétegződés és hullámos sorozathatárok közötti ferde rétegződés váltakozva építi fel. Utóbbit szenesedett növénymaradványok és magas csillámtartalom jellemzi. Az előző GSS-hez képest a szállítási energia csökkenése jellemzö, mely teret adott a természetes partgát kiépülésének, amit azonban időszakosan a medri folyamatok zavarnak meg.

A mederáttörési lóba üledéksora (I. GSS) a 11-1. GIS egységekből épül fel. A területen 3 szakaszban egy mederáttörési lóba kifejlődése zajlott. Az első, bevezető szakaszban az üledékekben megjelenő bioturbáció és réteges elválás kis vízmélységgel jellemezhető környezetre utal. A sorozatban a szemcseméret 3 alciklusban felfelé durvul. Az üledékben bioturbációs szerkezetek és terhelési szerkezetek figyelhetők meg. A bioturbáló szervezetek egy korábban sík, párhuzamos rétegződést dolgoztak át, mely felső áramlási rezsimből ülepedett ki. A 7. GIS- ben megjelenő suvadásos szerkezetek a természetes partgát lejtőjén megindult csuszamlásos folyamatokból származnak és a terület természetes partgáthoz való közelségét mutatják. A 6. GIS egység finom aleurolitjában előforduló szenesedett növénymaradványok partközeli környezetet feltételeznek. Az 5. GIS- ben a finom aleurolitra eróziós felszínnel települő finom és apróhomokkő is a mederáttörés hirtelen, nagy energiával bekövetkezett hordalékszállításáról és felhalmozásáról tanúskodik. Az előző szakasz kisebb partgátáttörését követően a terület valószínüsíthetően elgátolódhatott, illetve kis vízborítású területté vált, mert üledékeiben a finom és durva aleurolit, és agyagmárga lesz a domináns jellegzetes bioturbációs szerkezetekkel. Finom homokkő csak a 2. GIS- ben jelenik meg ismét durva aleurolittal kiékelődő sorozathatárok közötti ferderétegződést alkotva, mely a területet érő harmadik mederáttörési fázis terméke.

$\mathrm{Az}$ 3. sz. fúrás rétegsorának, üledékfácieseinek elméleti modelljét az 5-11. ábra szemlélteti. 


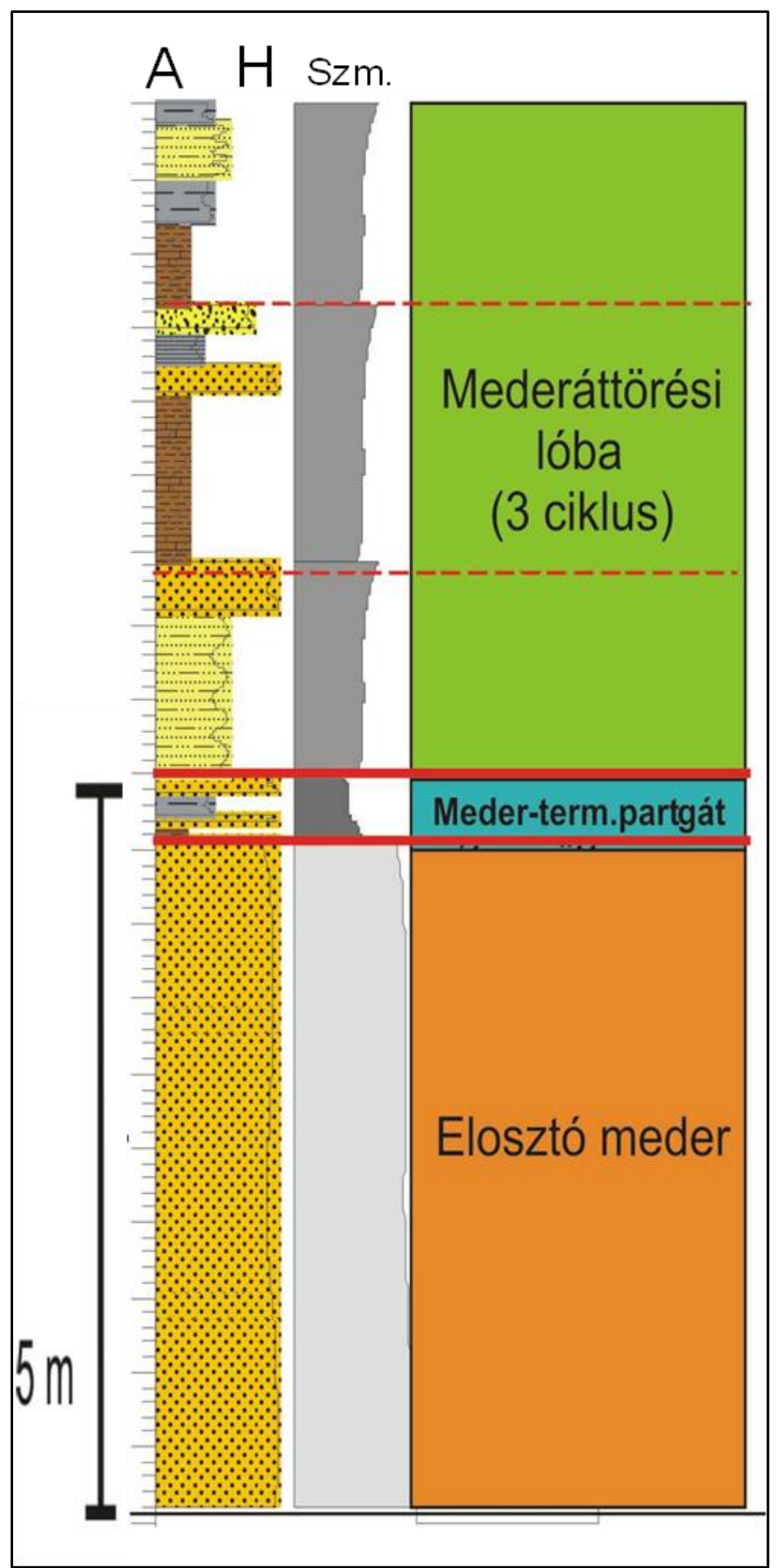

5-11. ábra A 3.számú mag üledékfáciesei (Geiger J.-. Sebők Sz., 2008) 


\subsubsection{Fejlödésmenet}

A rétegsor egy elosztó meder-meder és természetes partgát- mederáttörési lóba átmenetet tárt föl. A permeábilis tetö alatt 13,5 méterrel a homoktartalom-térképen jól látszik,hogy a térképezett terület DNy-i szegletében egy kisebb kiterjedésű, de erősen homokos 80-90\% homoktartalommal bíró lebeny jelentkezik, melyből egy DNy-ÉK-i csapásirányú hordalékelosztó meder tör ki (crevasse channel) (5-12. ábra). A fúráspont ennek ÉK-i elvégződésében helyezkedik el. A permeábilis tető alatt 12-12,5 méter között az elosztómeder progradációja látszik (5-12. ábra).

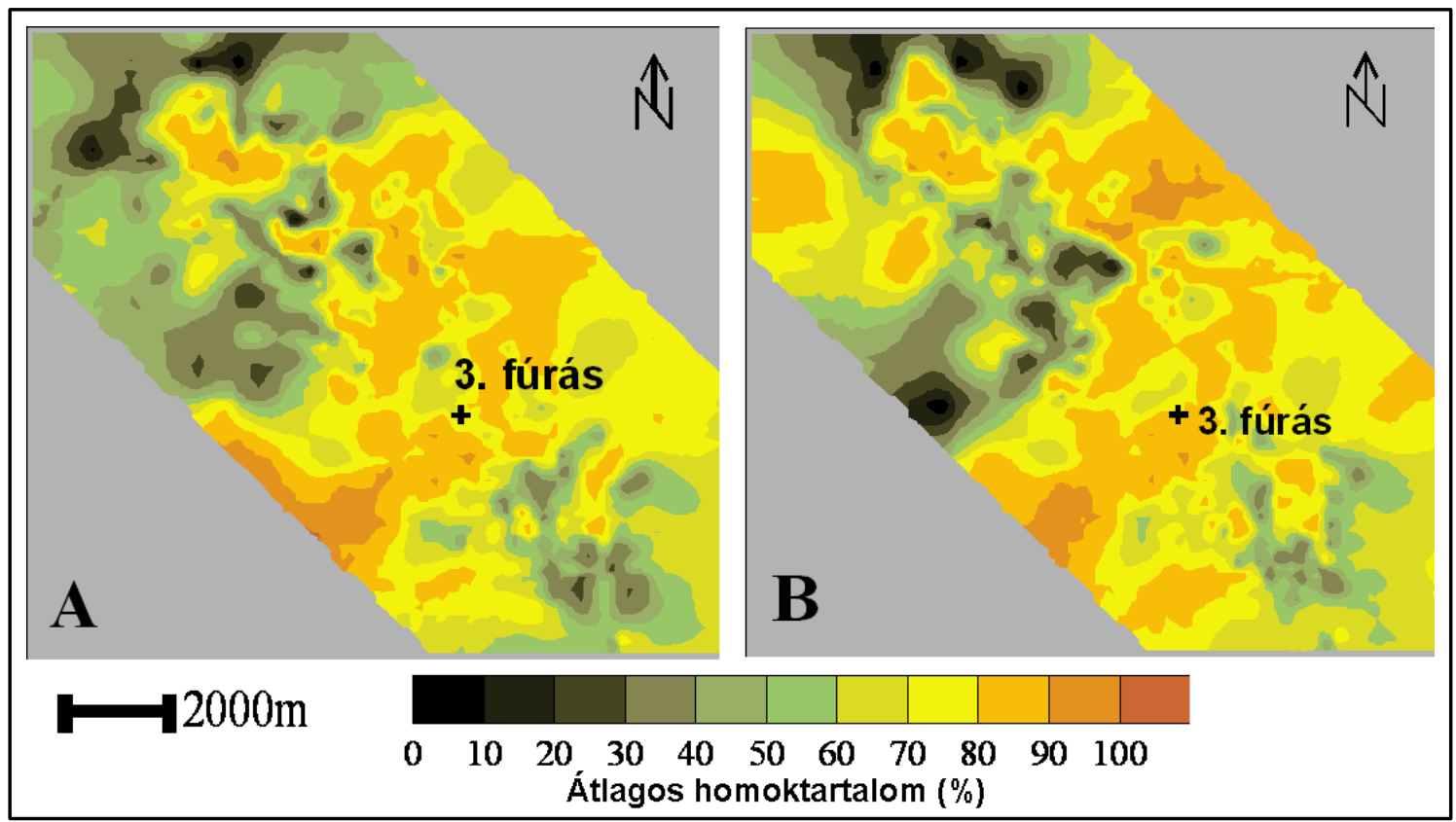

5-12. ábra Homoktartalom a permeábilis tetö alatt 13,5 (A) és 12 méterrel (B)

A meder nagy jelentőséggel bír a köztes területek feltöltődésében, illetve további kisebb elosztómedrek és természetes partgátak formálásában is. Az üledékutánpótlás csökkenése és/vagy az áramlási irányok megváltozása miatt a terület egyes részei elgátolódtak, és természetes partgát épülése vette kezdetét, mely a meder vonszolódása miatt két felfelé durvuló szemcsemérettel jellemezhető üledékciklusban ment végbe. Ezt követően a terület pangóvizes, kis vízborítású, iszapfaló és -lakó szervezetekben gazdag, áramlások által ritkán bolygatott partközeli környezetté fejlödött, ahol a feltöltő folyamatok vették át a szerepet, majd üledékeit 3 fázisban kifejlődött mederáttörési lóbaképződéssel járó folyamatok erodálták, és folytatták a feltöltést. 
A maganyag a permeábilis tetö alatt 4 méterrel véget ér, azonban a homoktartalom térképek alapján a továbbiakban mocsári képződmények halmozódtak fel a területen, melyek legnagyobb kiterjedésüket a tető alatt 3,5- 3 méterrel érik el (5-13. ábra). A Mississippi folyót analógiaként használva, a fúrás egykori, lehetséges környezetét az 5-14. ábra szemlélteti.

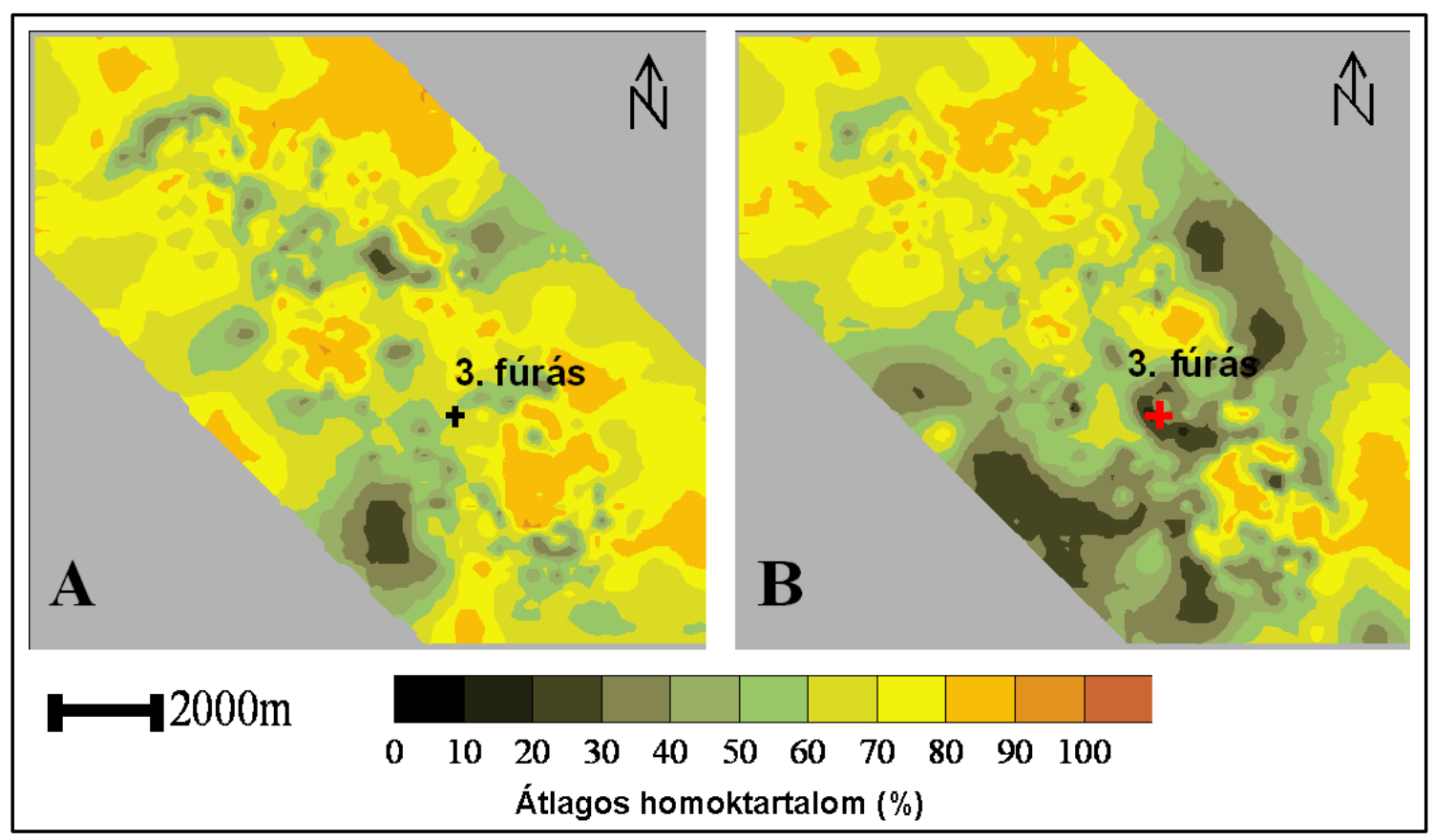

5-13. ábra Homoktartalom a PT alatt 4 (A) és 3 méterrel (B)

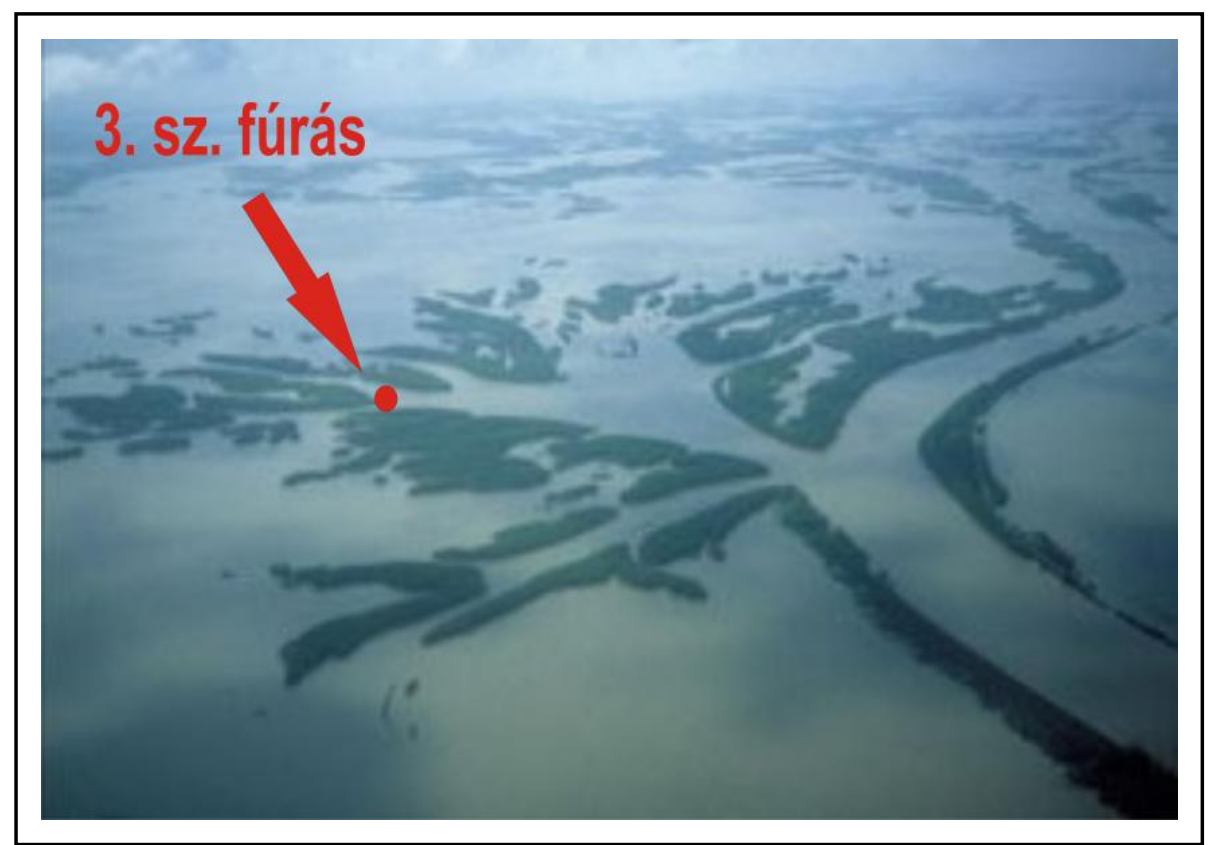

5-14. ábra A 3 sz. fúrás elméleti, lehetséges múltbeli környezete a Mississippi folyó analógiája alapján (fotó: Törnqvist, T.E. 1993) 


\section{4 Üledékfáciesek definiálása a 4. számú fúrás esetében}

A szedimentológiai magleírás a rétegsoron belül 20 GIS egységet különített el. A 20 GIS egység 9 nagyobb felhalmozódási környezetnek megfelelő GSS egységre osztható, melyek az alábbiak szerint alakulnak (5-1. táblázat):

\begin{tabular}{|c|c|c|}
\hline $\begin{array}{l}\text { GSS egység (Genetic } \\
\text { Sequence of Strata) }\end{array}$ & $\begin{array}{c}\text { Relatív mélység a } \\
\text { permeábilis tetőhöz } \\
\text { viszonyítva }(\mathrm{m})\end{array}$ & $\begin{array}{c}\text { GIS (Gen etic } \\
\text { Increment of Strata ) }\end{array}$ \\
\hline IX & PTF 11.50 - PTF 10.10 & 1 \\
\hline VIII & PTF 10.10-PTF 7.38 & 2 \\
\hline VII & PTF 7,38 - PTF 2,00 & 4.3. \\
\hline VI & PTF 2.00 - PTF 0.85 & 6.5. \\
\hline V & PTF 0,85 - PTA 2,83 & 8.7. \\
\hline IV & PTA 2.83-PTA 7.50 & 12.11 .10 .9 \\
\hline III & PTA 7,50 - PTA 13,70 & 13.14 \\
\hline II & PTA13,70-PTA 22.42 & 18.17 .16 .15 \\
\hline 1 & PTA 22.42-PTA 25.50 & 20.19 . \\
\hline
\end{tabular}

5-1. táblázat 4.sz. fúrás szedimentológiai, genetikai tagolása

A 4-es magfúrás első és második magrésze 36 méternyi üledékes kőzetet tárt fel. A teleptető a geofizikai mérések alapján az V. GSS egységben található, így a magfúrás felső mintegy 10 métere nem képezi a Szőreg-1 telep részét.

A 4. sz. fúrás 9 fácies környezeteiben és alkörnyezeteiben felhalmozódott üledékeinek fáciesei : progradáló meder $\rightarrow$ mederáttörési lóba $\rightarrow$ progradáló mederáttörés $\rightarrow$ mocsár $\rightarrow$ hordalékelosztó meder $\rightarrow$ mocsár $\rightarrow$ természetes partgát $\rightarrow$ elosztó meder $\rightarrow$ mocsár/ártér).

A progradáló meder üledéksora (I. GSS) a 20. és a 19. GIS egységet foglalja magában. $\mathrm{Az}$ egység a permeábilis tető alatt 25,5 méterrel kezdődik, és a tető alatt 22,48 méter mélységben ér véget. Az egység felfelé durvuló sorozatokból épül fel, melynek kezdő tagja finom aleurolit, agyagmárga és finom homokkő ciklikus váltakozásával indul (20. GIS), mely áramlásoktól csak gyengén háborgatott környezetre utal. Ezt felváltja egy szerkezet nélküli finomhomokos apróhomokkő, mely a szállító-felhalmozó közeg energiájának hirtelen megnövekedését bizonyítja, valamint azt, hogy az áramlásból való kiülepedés olyan hirtelen valósult meg, hogy az üledékszemcséknek nem volt idejük belső rétegződést, szerkezetet kialakítani (19. GIS). Ezek a folyamatok jól példázzák egy progradáló meder mozgását, mely kezdetben finom, majd egyre durvuló szemü üledéket halmoz fel a progradáló mozgás előrehaladtával. 
A mederáttörési lóba üledékfáciese (II. GSS) a 18., 17., 16. és a 15. GIS egységeket foglalja magában. A mederáttörés három fázisban történt, melynek felfelé durvuló ciklusai egymástól jól elkülönülnek. Az első áttörés volt a legerőteljesebb, és egyben a legtöbb homokos üledéket felhalmozó fázis. Kezdő sorozatai (18., 17., 16. GIS) finom és durva aleurolitból, illetve agyagmárgából épülnek fel, melyek bioturbáltak. A pangóvízi időszakban a magas szerves anyag tartalmú agyagból idővel szenes agyag alakult ki. Ezeket a finomszemü üledékeket erodálta az 1. ciklus hirtelen betörő áramlása, mely az addig települt üledékekre eróziós felszínnel települt finomhomokos apróhomokkő (14. GIS). Az első mederáttörés után csendesvízi időszak következett, melyben a lebegtetett üledékekből agyagmárga települt, majd a második mederáttörés áramlásai újabb apróhomokkövet szolgáltattak. Ez az agyagmárga- apróhomokkő ciklus a 3. mederáttörés során is megismétlődött. A finomhomokos apróhomokkőben gyakoriak az összeolvadási felszínek és intraklasztok, a párhuzamos sorozathatárok közötti ferde rétegződés, a szaggatott réteglemezek, és alárendelten, a gyengébb áramlású szakaszokban a flázeres rétegződés is megjelenik.

A III. GSS egységet (14., 13. GIS) valószínüsíthetően az előzőekben kialakult egyik mederáttörés progradációjának üledékei építik fel. A progradáció 3 felfelé durvuló ciklusban nyilvánul meg, Az első ciklus a legerőteljesebb, a második kettő kisebb mértékü előrehaladásról tanúskodik. A ciklusok bevezető szakasza általában finom aleurolit, durva aleurolit, agyagmárga, illetve ezek váltakozó rétegződése. A progradáció időszakaiban apró és középszemü homokkő halmozódott fel a területen. A réteglemezek anyagában szenes növényi maradványok és csillám jelenik meg, mely jelzi a lehordási terület vegetációgazdagságát, és az üledékek áthalmozott jellegét.

A IV. GSS a 12., 11., 10., és 9. GIS egységek üledékeiből épül fel, és jellegzetes mocsári üledékekből áll. A felfelé finomodó sorozat jelzi a korábbi mederáttörés elgátolódását, így a sorozat finom homokkő- homogén finom aleurolit- szenes agyag egymásra következő rétegeivel kezdődik, majd a ciklus végén finom és durva aleurolittal zárul. A kezdetben még gyenge áramlások által felhalmozott finomhomokkő helyét később a szuszpenzióból kiülepedő finomszemü üledékek veszik át. A leveles elválású szenes agyag partközeli, anoxikus, áramlásmentes, időnként kiszáradó, majd újra vízborítás alá kerülő környezetet feltételez.

Az V. GSS (8. és a 7. GIS egységek) egy hordalékelosztó meder környezetét feltételezi. A meder kiépülés agyagmárga, finom aleurolit és finomhomokkő üledékekkel kezdődik, majd több mint 3,00 méter vastagságban finomhomokos apróhomokkő települt, melyre jellemző a mederképződmények egymásra települését bizonyító összeolvadási 
felszínek megjelenése, az erős lineáris áramlást jelző, felső áramlási rezsimben felhalmozódott sík párhuzamos rétegződésű egységek ciklikus megjelenése, valamint az áramlás irányváltásait mutató kiékelődő sorozathatárok közötti ferde rétegződés. A réteglapok anyagában szenes növényi törmelék és csillám jelenik meg.

A VI. GSS (6. és 5. GIS) mocsári üledékei a hordalékelosztó meder elgátolódásáról, az áramlási viszonyok megszüntéről tanúskodnak. Az egység agyagmárgából épül fel, mely helyenként lencsés, illetve alsó áramlási rezsimben kialakult sík párhuzamos rétegződést mutat, Üledékeinek szerves anyag tartalma magas, benne szenes agyag betelepülést találunk. A következő üledékes egység ezt a pangó vízi üledékes egységet erodálva települt.

A VII. GSS (6. és 5. GIS) alul flázeres rétegződésű, és kiékelődő sorozat határok közötti ferde rétegződést mutató finom homokkővel indul, mely egy víz alatti természetes partgát kiépülésének kezdetét jelzi. Erre finom aleurolit és agyagmárga rétegek települtek, melyben gyakori a suvadásos szerkezet, a lejtős térszínt bizonyítva. Az üledékek bioturbáltak, terheléses szerkezetek jelennek meg bennük, és több helyütt kiékelődő sorozathatárok közötti ferde rétegzettséget mutatnak. Az üledékekben sok szenesedett növénymaradvány és csillám fordul elö, mely a vegetációban dús, kiemeltebb helyzetü területekről került az üledékekbe.

Az elosztó meder üledékei az előző egység üledékeit erodálva települtek . A VIII. GSS egység finomhomokköve felső áramlási rezsimben kialakult sík párhuzamos rétegződést, és kiékelődő sorozathatárok közötti ferde rétegződést mutat. Az erodáló jelleg az áramlás erősségét mutatja. Az üledékszerkezeti jegyek alapján nagy energiájú linearitást feltételezhetünk, ami időnként áramlási irányát megváltoztatva kiékelődő sorozathatárok közötti ferde rétegződést alakít ki. A szenes növényi törmelékek és a magas csillámtartalom itt is megjelenik.

A IX. GSS üledékei újabb mocsári képződmények. Az ekkor felhalmozódó földes törésủ agyagmárga a korábbi elosztó meder megszűnését, elgátolódását, a terület kiszáradását, időszakos vízborítottságát bizonyítja. A 4. sz. fúrás rétegsorának, üledékfácieseinek elméleti modelljét az 5-15. ábra szemlélteti. 


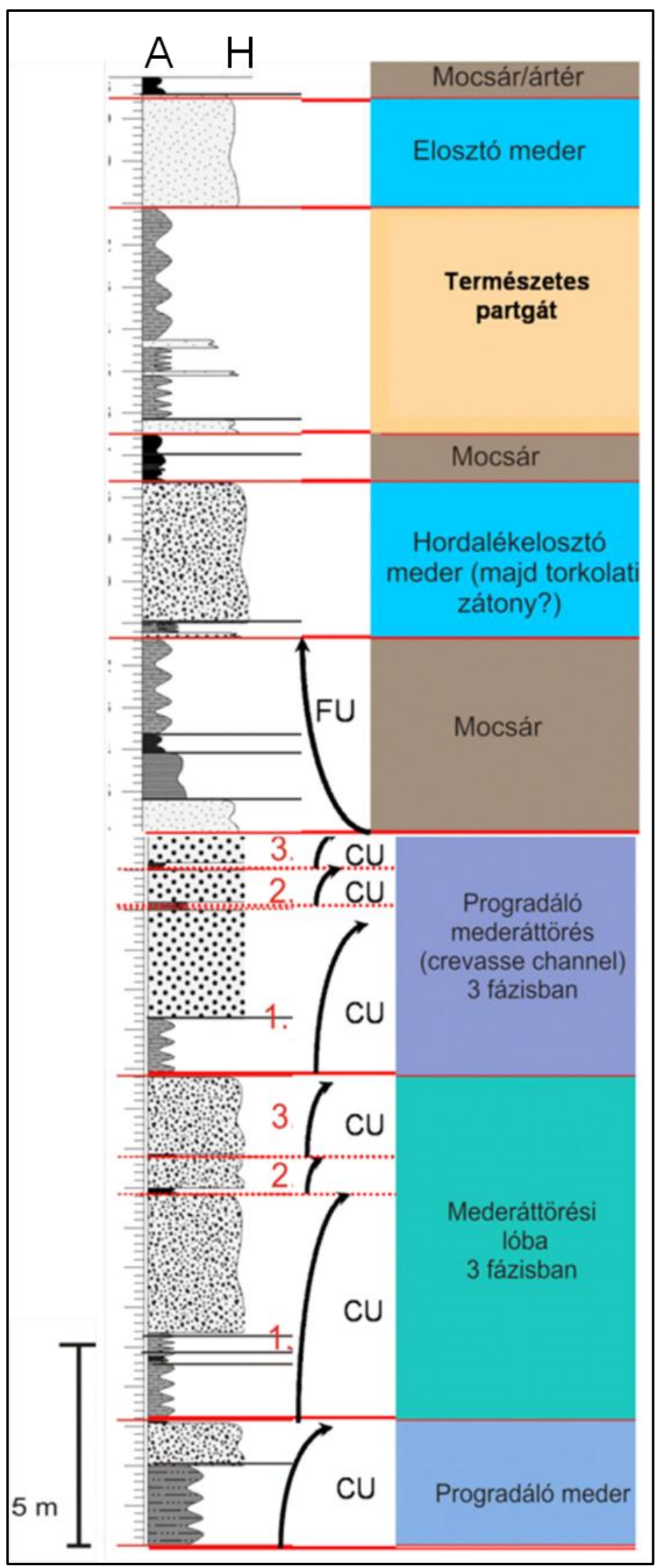

5-15. ábra A 4. sz. fúrás rétegsora és üledékfácieseinek elméleti modellje (Geiger J.-. Sebök Sz., 2009) 


\subsubsection{Fejlődésmenet}

A rétegsor progradáló meder mederáttörési lóba- progradáló mederáttörés- mocsárhordalékelosztó meder- mocsár átmenet üledékeit tárta fel (csak a Szőreg-1 telepet vizsgálva). Az üledékfácies térbeli kiterjesztését a homoktartalom térképek felhasználásával vizsgálva a folyamatot jól illusztrálják az egyes metszeti térképek.

A 4. sz. fúrás egy ÉK-i irányból progradáló torkolati zátony előterében helyezkedik el (5-16. ábra, A). A torkolati zátony fejlődése és a belső területek felőli kisebb meder progradációk határozzák meg a fúráspont üledékes környezetének változékonyságát. A rétegsor a permeábilis tető (PT) alatt 25,5 méteres mélységben kezdődik. A PT alatt 24,5 méterrel egy a belső területek felől induló, progradáló meder üledékei töltögetik a területet. A feltöltés nem csak egy irányból történik. A PT alatt 23 méterrel már egy ÉK-i mederág is betör a területre, és homokosabb üledékeket halmoz fel (5-16. ábra).

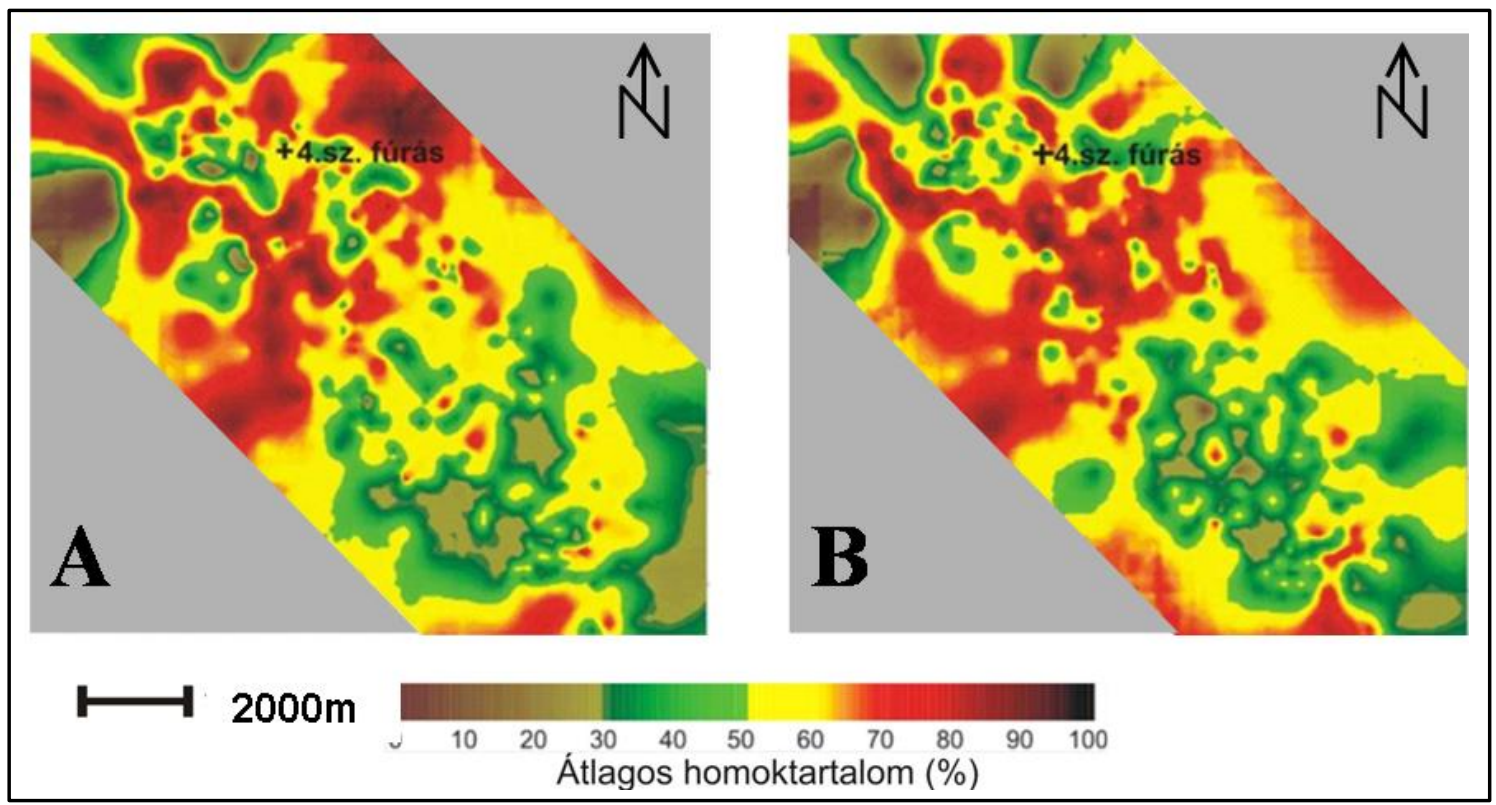

5-16. ábra Homoktartalom térképek a permeábilis tetö alatt 24.5 (A) és23 méterrel(B)

Ezt követően egy mederáttörési lóba kiépülése veszi kezdetét, mely 3 fázisban követhető nyomon a felhalmozott üledékek belső szerkezete, és a homoktartalom térképek alapján is. Bevezető szakaszában kisebb homoktartalmú egységek, finom aleurolit és agyagmárga települ (5-17. ábra). A betörés az ÉK-i torkolati zátony felöl, illetve egy nyugati irányból előretörő meder által valósulhatott meg, melynek legerőteljesebb szakaszát a 5-18. ábra mutatja. Ekkor a fúráspont területén egyértelmüen a magas, 90-100 \% homoktartalmú, medri üledékek válnak uralkodóvá, és jól látszik, hogy a terület valószínüleg éppen a mederáttörések kapujában fekszik. 


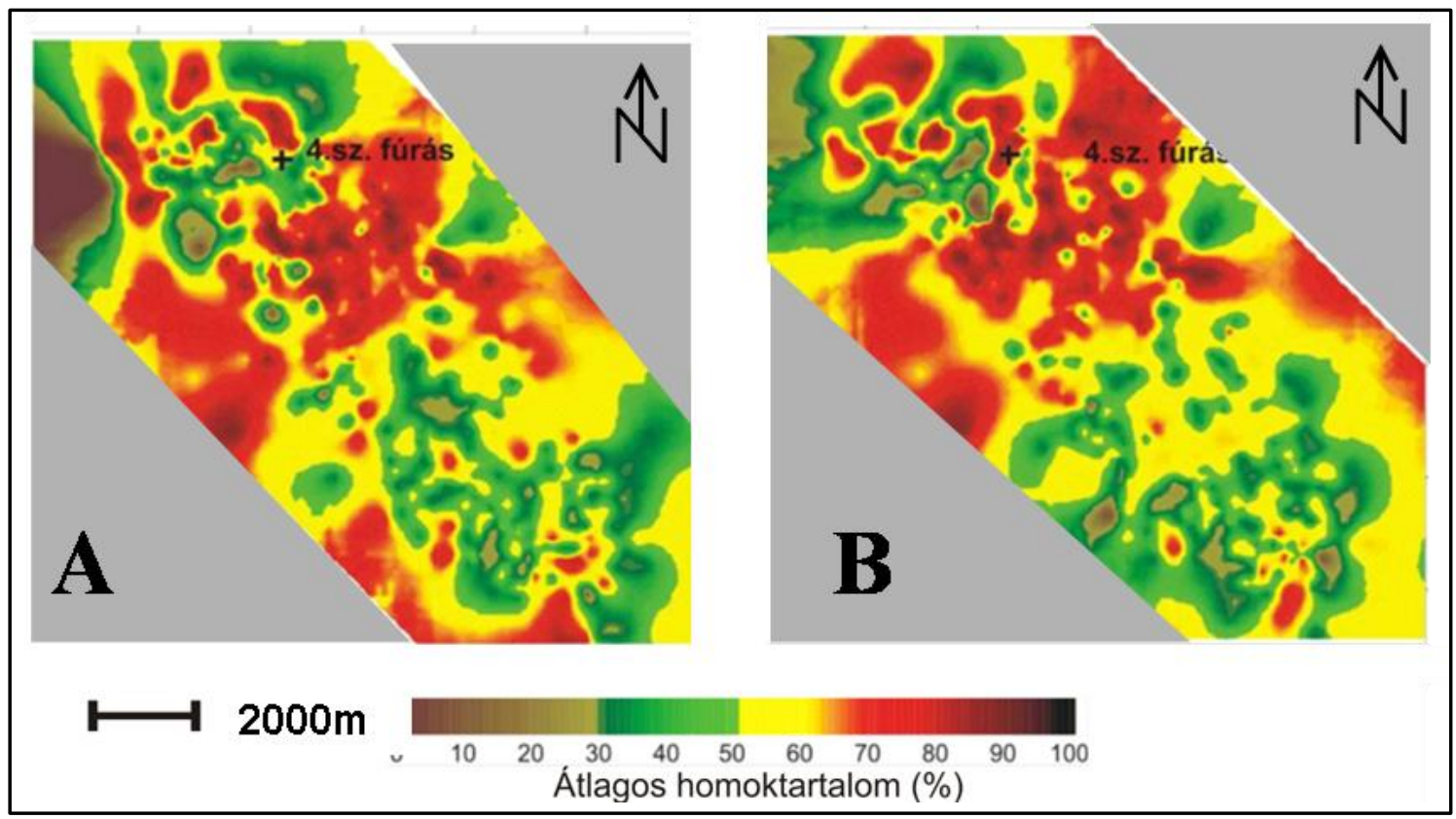

5-17. ábra Homoktartalom térképek a permeábilis tetö alatt 21.5 (A) és20 méterrel(B)

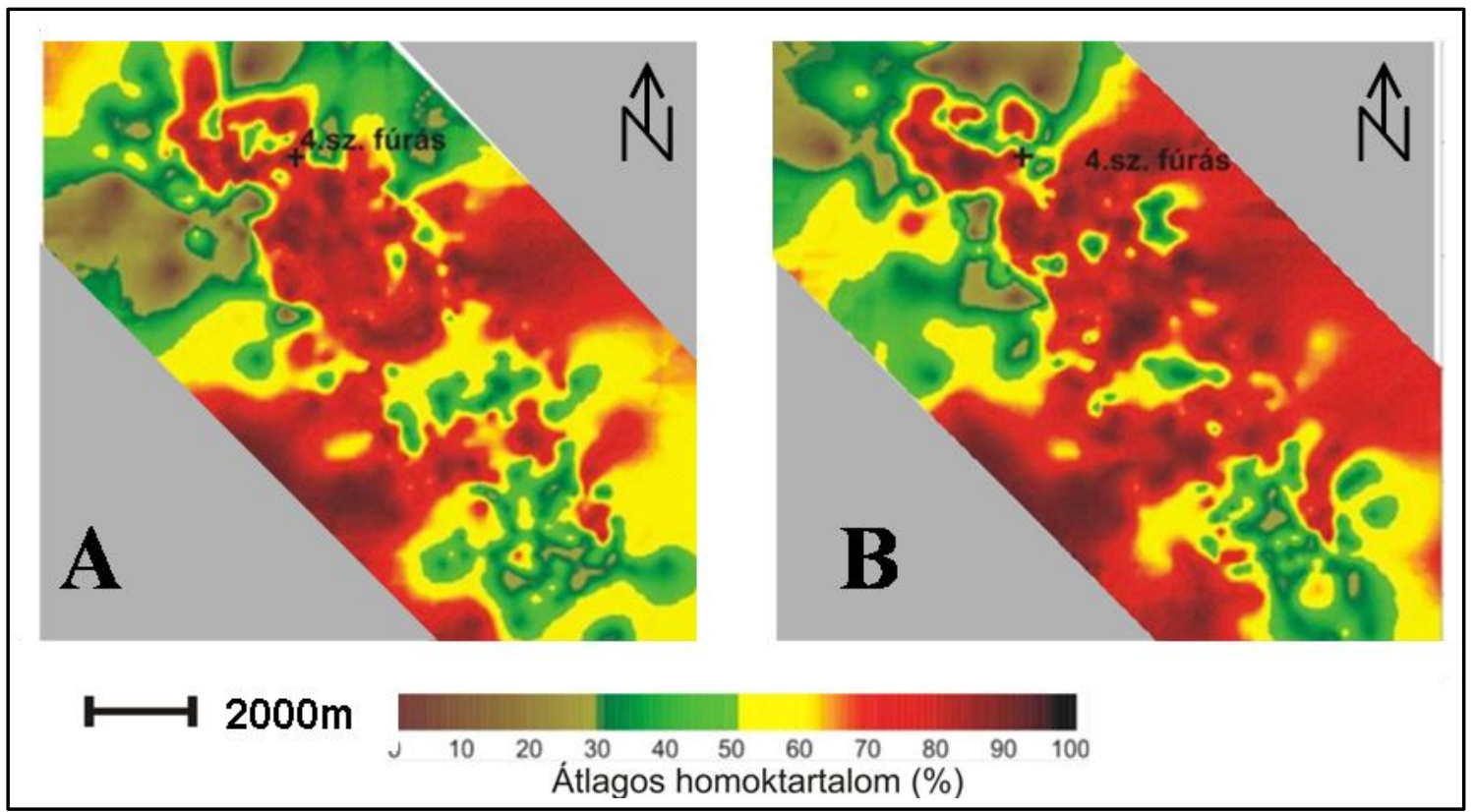

5-18. ábra Homoktartalom metszeti térképek a permeábilis tetö alatt 16 (A) és 14.5 méterrel (B)

A permeábilis tető alatt 13,5 méter mélységben ennek a mederáttörésnek nyugati irányba való további progradációja látszik. Ekkor kapcsolata az ÉK-i torkolati zátonyon kifejlődött mederrendszerrel meghatározónak tünik (5-19. ábra, B). Időszakosan azonban egy dél-délnyugatról progradáló torkolati zátonnyal is kapcsolatban áll (5-20. ábra, A). 


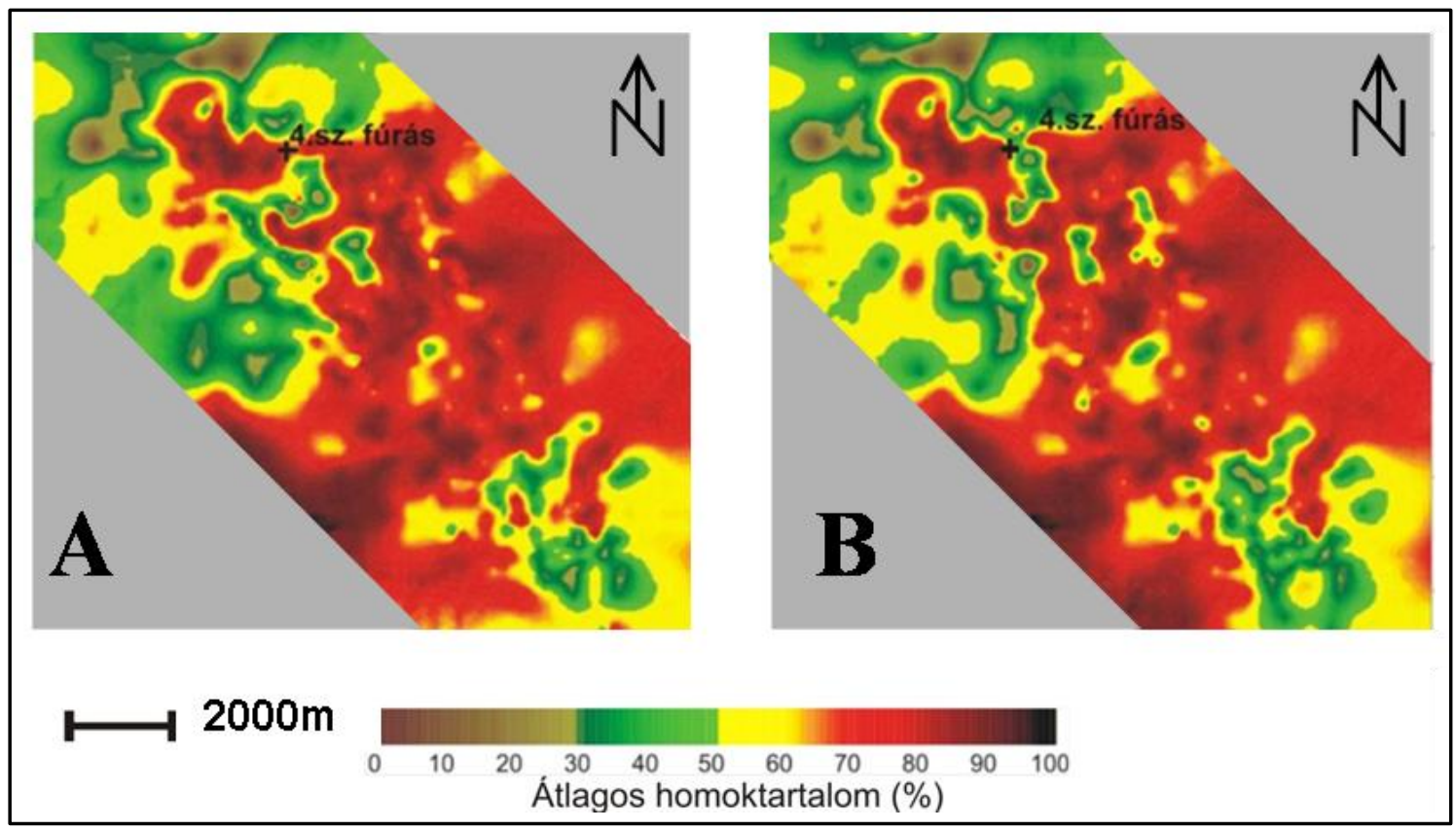

5-19. ábra Homoktartalom metszeti térképek a permeábilis tetö alatt 14 (A) és 13.5 méterrel (B)

A progresszív időszakot követően a terület elgátolódik (5-20. ábra, B), az azt tápláló medrek is feltöltődnek, visszaszorulnak, így üledékutánpótlása már csak a pangóvízi vagy kiemeltebb partközeli környezet irányából valósulhat meg. Ennek következtében a terület elmocsarasodik, vízborítása csekély, időszakosan kiszárad. Magas szerves anyag tartalmú üledékei a parti régióból kerülhettek ide, melyet a rétegsorban a szenes agyag megjelenése bizonyít (5-21. ábra).

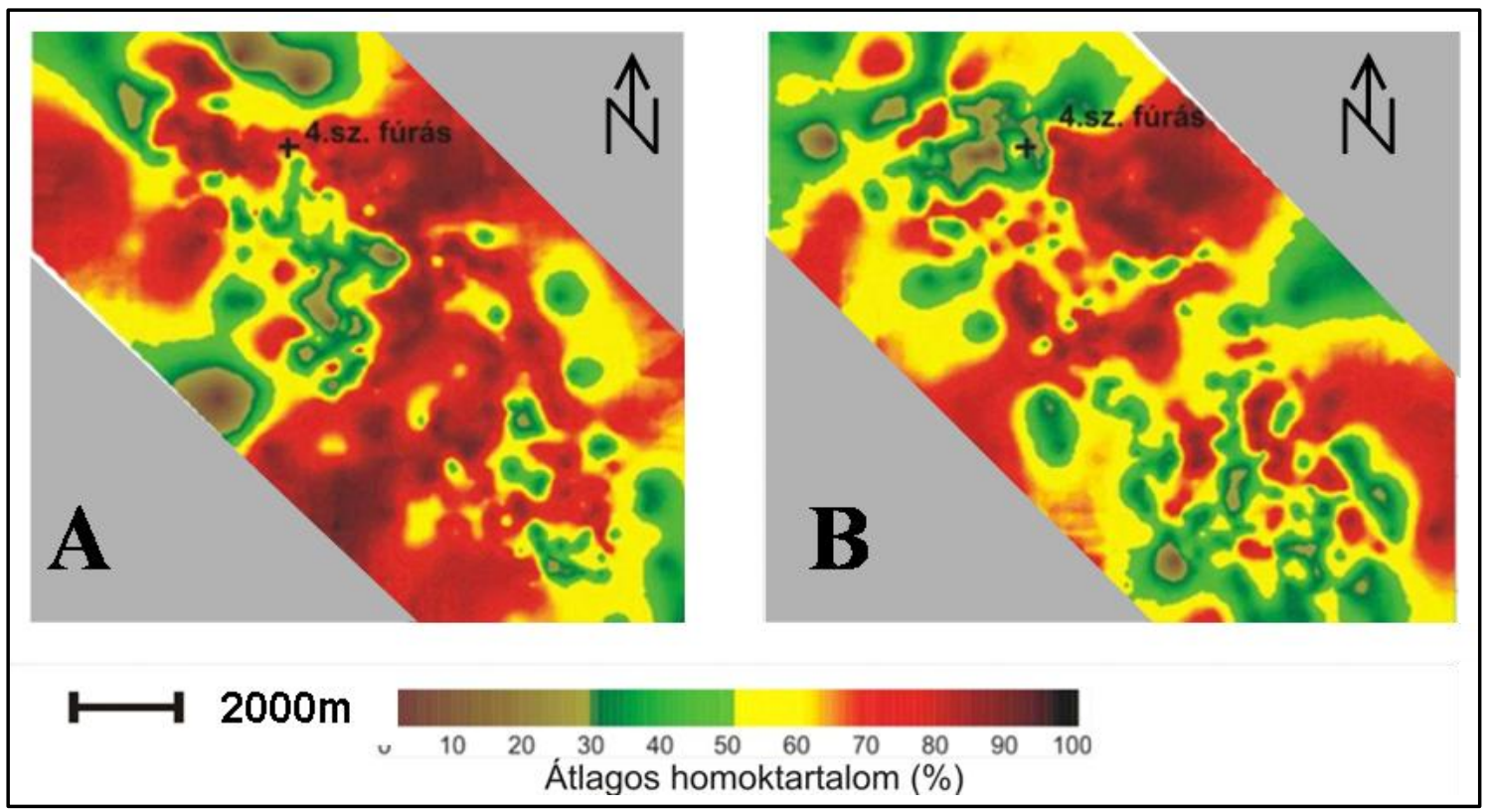

5-20. ábra Homoktartalom metszeti térképek a permeábilis tetö alatt 11.5 (A) és 8 méterrel (B) 


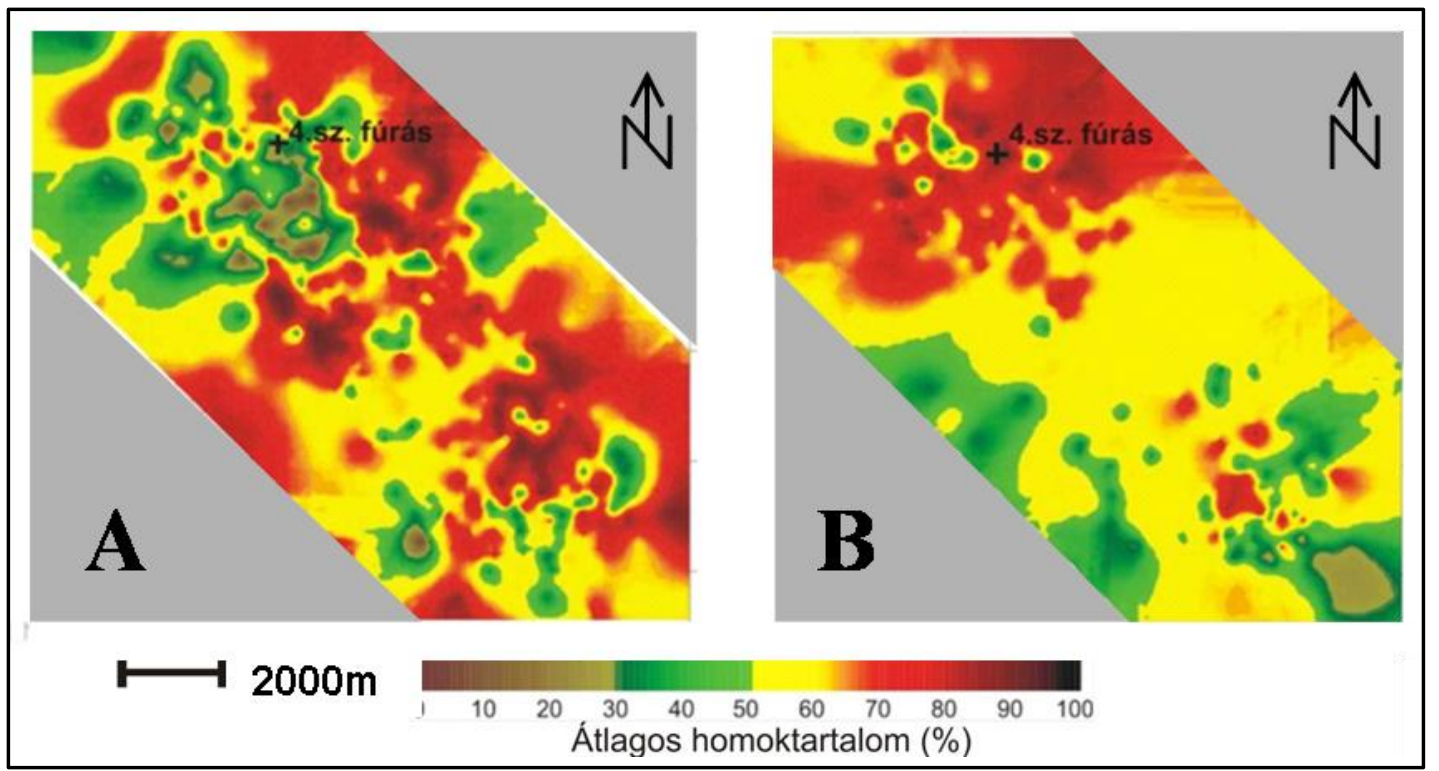

5-21. ábra Homoktartalom metszeti képek a permeábilis tetö alatt 5,5 (A) és 0,5méterrel(B)

A homokos üledékekben szegény időszakot hordalékelosztó meder kiépülésének időszaka váltja fel, erodálva az addigi szuszpenzióból leülepedett üledékeket. Az aktív vízmozgás időszakának homokos üledékeit két irányból származhatnak. Egyik lehetőség a délnyugat- nyugati torkolati zátony északkelet felé való progradációja, majd azokon medrek kiépülése, ami fokozatosan elönti a területet, és medret mélyít, vagy a korábbi, ÉK-i torkolati zátonyon épült mederrendszerrel való megélénkülő kapcsolat, mely dél-délnyugati irányba való progradáló mozgásával egyre nagyobb homoktestet épít ki (5-21. ábra, B).

A 4. számú fúráspont egyik lehetséges, múltbeli környezetét és elhelyezkedését az 5-22. ábra mutatja. A homoktartalom térképek rétegsoron belüli elhelyezését az 5-23. ábra segíti.

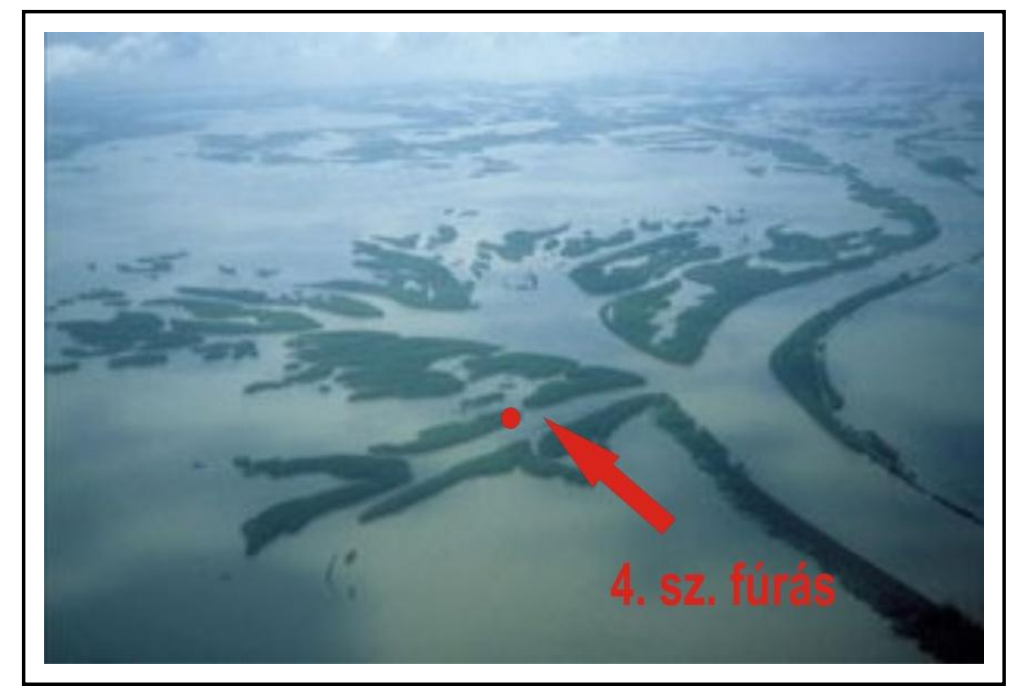

5-22. ábra A 4 sz. fúrás elméleti, lehetséges múltbeli környezete a Mississippi folyó analógiája alapján ( fotó: Törnquist, T.E. 1993 ) 


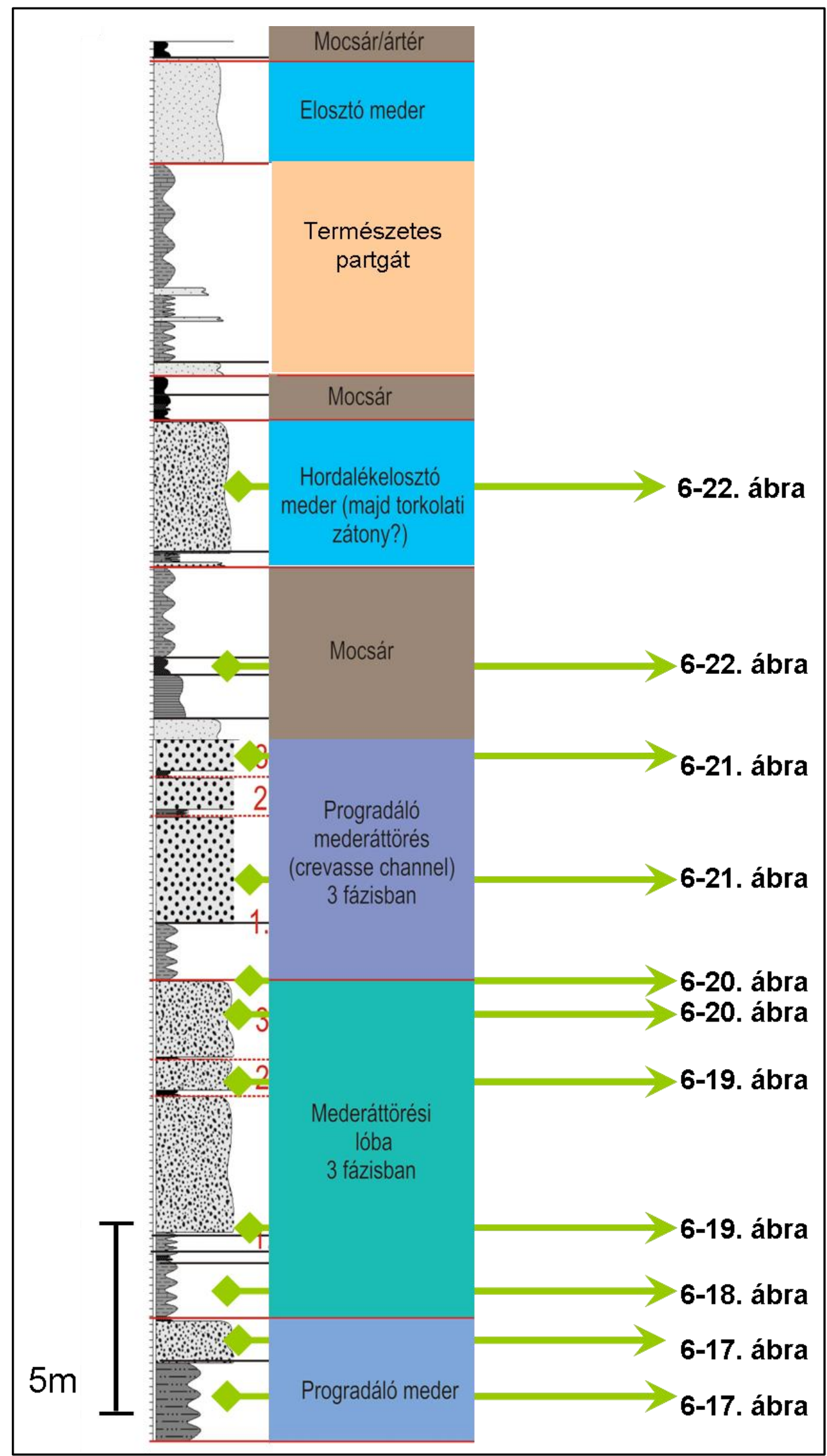

5-23. ábra A 4. számú fúrás homoktartalom térképeinek elhelyezkedése a rétegsoron belül 


\section{A maganyagban megjelenő üledékszerkezeti jegyek}

Az üledékképződési viszonyok megismerésének egyik eszköze a felhalmozó közeg energiaviszonyairól tájékoztatást nyújtó üledékszerkezeti jegyek vizsgálata. A felhalmozó közeg hasonló energiaviszonyai azonban nem minden esetben jelentenek ugyanolyan felhalmozódási környezetet, ezért azoknak üledékes fáciesekben való megjelenéseit vizsgálva a következőket lehet megállapítani:

\subsection{Az elosztó medrek üledékszerkezeti jegyei}

A fáciesben megjelenő szerkezet nélküli homokkövek a nagy szállítási energia eredményei (III-4. melléklet). A gyakori folytonos és szaggatott ferde rétegződés (III-1 III-3. melléklet) csak egyirányú áramló vízben tud kialakulni. A kúszóhullámos rétegződés a rendkívül gyors sebességű vízfolyás bizonyítéka (III-5. melléklet).

\subsection{A meder és természetes partgát-komplex üledékszerkezeti jegyei}

Ebben a környezetben is megjelenik a hullámos sorozathatárok közötti ferde rétegződés (III-6. és III-10. melléklet), és a kaotikus, erősen gyüredezett, csuszamlásos jellegü szerkezetek (III-7. és III-9. melléklet), melyek a partgát lejtőjén megcsúszott üledékek öbölbeli felhalmozódásai. A szintén gyakori konvolút réteglemezek a rétegek atektonikus gyüredezettségének megnyilvánulásai (III-8. melléklet), melyek ugyancsak a lejtős térszínekhez kapcsolódó folyamatok eredményei. A partközeli helyzet bizonyítéka a behordott növényi maradványokból kialakult, magas szervesanyag tartalmú szenesedett növényi törmelékes, szenesagyagos rétegek megjelenése (III-11. melléklet).

\subsection{Mederáttörési lóba üledékszerkezeti jegyei}

A delta környezetben a mederáttörési lóbák sorozatában gyakori a szerkezet nélküli homokkövek megjelenése (III-12., III-13., és III-16. mellékletek), melyek vonszolásmentes hordalékmozgás eredményeként halmozódnak fel. Homogén belső szerkezetük szuszpenzióból történő gyors kiülepedés következménye. Gyakran aleurolit és agyag intraklasztokat tartalmaznak, melyek a gyengén konszolidált üledékek erodálásából származnak. A mederáttörési ponton keresztüláramló, nagy energiájú víztömeg az üledékét a hirtelen lecsökkenő mozgási energia miatt osztályozatlan formában, hirtelen ülepíti ki, útja során pedig a gyengén konszolidált aljzatból klasztokat ragad magával, melyek az energiacsökkenés miatt az üledékbe „fagyva” települnek le, akár imbrikált formában is (III19. melléklet) 
A ferde rétegződés megjelenése a mederáttörési lóba környezetben alárendelt. Áramlási fodrok migrációja során alakul ki, egyirányú áramlóvízi környezetet jelez, de mindenképp a mederáttörésnél kisebb energiájú közeget (III-18. melléklet).

A hullámos sorozathatárok közötti ferde rétegződés a gyors, szuszpenziós kiülepedés jelzője. Periodikus áradások jelenlétét jelzi, többnyire az elgátolódási szakaszokban települt üledékeket (III-14. melléklet) váltja fel.

A sík párhuzamos rétegződés a felső áramlási rendszer erős lineáris áramlásai során alakul ki (III-15. melléklet). Alsó áramlási rendszerben felhalmozódott finom és durva aleurolitban is megjelenik a mederáttörési lóba területének elgátolódása folytán (III-17. melléklet). Ilyen esetben fennmaradásukhoz állóvízi környezet, a törmelékszállítás időszakos ingadozása és iszapfaló szervezetek tevékenységétől való mentesség szükséges.

A mederáttörési lóba üledékei között jellegzetes deformációs szerkezetek is megjelennek, mint például a terheléses szerkezetek, melyek a képlékeny üledékek gyors ülepedés miatt fellépő hirtelen terhelés miatt alakultak ki az agyagmárga határán.

\subsection{Crevasse channel és progradációja üledékszerkezeti jegyei}

Üledékszerkezeti jegyei a crevasse channel progradációja során jelentkező folyamatok, és energiaviszonyok miatt hasonlóak a mederáttörési lóba üledékszerkezeti jegyeihez.

A szerkezet nélküli homokkövek a crevasse channel progradációját jelzik, intraklasztok nem jelennek meg bennük (III-21 és III-22. mellékletek), mely a mederáttörésnél kisebb mértékü eróziós hatásra enged következtetni, és az így kialakuló meder fokozatosabb mértékü előrehaladását valószínűsíti. A ferde és szaggatott hullámos rétegződés szintén az áramló közegből történő kiülepedést jelzi (III-20. melléklet).

A sík párhuzamos rétegződés felső (III-24. melléklet) és alsó áramlási rezsimben is megjelenik (III-23. melléklet). Utóbbi esetben szenesedett növénymaradványokkal és csillámmal fordul elö, ami a terület partközeliségét és rövid szállítási útvonalat feltételezi.

Az előforduló kiékelődő sorozathatárok közötti ferde rétegződés az áramlási irányok megváltozását, a crevasse channel progradációjának iránymódosítását jelzi (III-23. melléklet, mag teteje).

\subsection{Mocsár és mederfelhagyás üledékszerkezeti jegyei}

A tipikus mocsári környezetben felhalmozódott üledékekben gyakori a bioturbáció (III25., III-26., és III-30. mellékletek), az alsó áramlási rendszer sík párhuzamos rétegződése (III-27. és 3-28. melléklet), és a megszakadó sík párhuzamos rétegződés terhelési zsebekkel a gyengébb áramlások által töltődő, de túlnyomórészt pangóvizes, mocsarasodó területeken. A rétegsorban gyakori a leveles törésü szenesagyag rétegek megjelenése (III-29. melléklet). 


\section{Modellezés különböző léptékekben - Mikroléptékü heterogenitás- és fluidumáramlási vizsgálat CT-vel}

\subsection{A vizsgálatok célja}

A szénhidrogén tároló kőzettestek heterogenitását a kőzetben az áramlási akadályként (baffle), vagy áramlási gátként (barrier) viselkedő kőzetrészek okozzák. Minden tároló változó mértékben és léptékben geológiailag heterogénnek tekinthető. Az ilyen heterogenitások a permeabilitás olyan változékonyságát okozzák, ami kedvezőtlenül hat a szénhidrogének vándorlására, eloszlására és termelésére. Ezért a hatékony másod- és harmadlagos termelési folyamatok fejlesztéséhez elengedhetetlen ezen permeabilitás heterogenitások térbeli és nagyságbeli pontos ismerete, számszerüsítése (LEWIS, J. J. M. 1988). A tárolók heterogenitásának vizsgálatával, illetve modellezési lehetőségeivel egyre több kutatás foglalkozik (például RINGROSE, P. et al, (2005), WEN, R. 2006, Kolterman, C. E.GORELICK S. M, 1996, vagy MEYER, R.- KRAUSE F. 2006), hiszen a permeabilitás a termelés és a tárolás szempontjából az egyik legmeghatározóbb tárolóparaméter.

A tároló heterogenitása egyaránt jelentkezhet a pórusszerkezet, az üledékszerkezeti jegyek, a litofácies, vagy a kőzettest szintjén is (WEN, 2006). Már a centiméteres léptékben jelentkező heterogenitásnak is meghatározó szerepe lehet a termelés megbízható előrejelzésében a fluidum-áramlási tulajdonságok pontos ismeretén keresztül (WILLIS B. J. WHITE C.D., 2000).

A 7-1. ábra a tárolók heterogenitásának termelésre gyakorolt hatását mutatja egy feltételezett gázbesajtolás mellett (AYAN, C. et al., 1994). Egy gázbesajtolás esetében homogén tárolókban a kisöprési hatékonyság alacsony. Ha a tárolót szórványosan több permeabilitási akadály - például aleuritos, agyagos rétegek - tagolják, a hatékonyság nő. A leghatékonyabb kisöprés az összefüggő, homokos képződményeket izoláló permeabilitási gátak jelenlétében valósítható meg (AYAN, C. et al, 1994).

Egy tulajdonság egy bizonyos irányban vizsgált változásait az anizotrópia írja le. Egy anyag anizotróp, ha a vizsgált tulajdonságot leíró vektor értéke irányfüggő. Mind az anizotrópiára, mind a heterogenitásra érvényes a léptékfüggőség, azaz mindkettőt befolyásolja a minta mérete és a mintázás felbontása, azaz nem jelenthetjük ki egy kőzetről, hogy anizotróp anélkül, hogy nem definiálnánk a minta, és a mintázás felbontásának léptékét (ANDERSON, B. - HELBIG, K.,1994). 


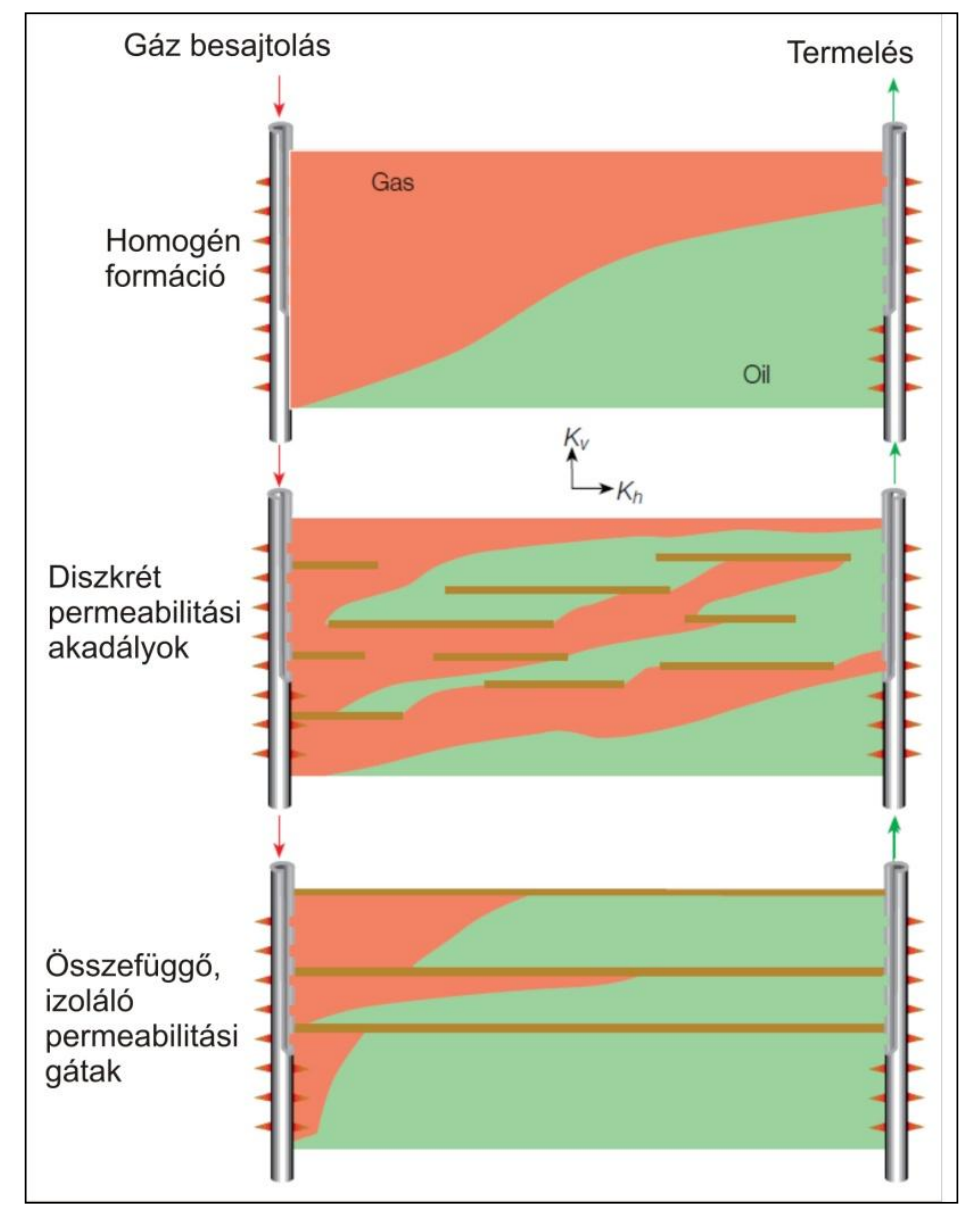

7-1. ábra A tárolóheterogenitás hatása a termelési folyamatokra (Ayan, C.et al, 1994)

Az üledékes kőzetek anizotrópiája a felhalmozódás, és az azt követő folyamatok eredménye. Törmelékes üledékek esetében az anizotrópia feltétele egy rendező folyamat fellépése. Amennyiben egy kőzet az 5 alapvető tulajdonsága alapján - szemcseösszetétel, méret, -alak, orientáció és tömöttség - heterogén, az anizotrópia nem tud kifejlődni, mert az anyagban nincs jelen legalább egy fö irányultság. A rétegződés léptékének szintjén az anizotrópiát két tényező alakíthatja ki: az eltérő litológiájú rétegek váltakozása, vagy a szállító közeg felhalmozódással egyidejü mozgásának irányultsága. Az így kialakult anizotrópiát a diagenetikus folyamatok később befolyásolhatják (ANDERSON, B. - HELBIG, K., 1994, MEYER $R$., 2002). A permeabilitás anizotrópiáját gyakran a függőleges és a vízszintes permeabilitás hányadosaként adják meg $\left(\mathrm{k}_{\mathrm{v}} / \mathrm{k}_{\mathrm{h}}\right)$.

Rétegződés szintjén a keresztrétegződés nagy érdeklődésre tart számot, mert ha egy formáción belül a keresztrétegzett sorozatok azonos irányultsággal rendelkeznek, sokkal nagyobb hatásuk van a folyadékáramlás anizotrópiájára, mint a pórus- léptékü anizotrópiának (ANDERSON, B. - HELBIG, K. 1994). 


\subsection{Ferde rétegződés egyfázisú áramlásos vizsgálata CT- vel}

A lamina- és rétegződés léptékủ permeabilitás anizotrópia vizsgálata során RINGROSE kimutatta, hogy a vizsgált üledékszerkezetnek jelentős hatása volt az effektív permeabilitás tenzorra (RINGROSE et al, 1999). A keresztrétegződés mellett a ferde rétegződés is nagy jelentőséggel bírhat a fluidum áramlás és a permeabilitás heterogenitása és anizotrópiája szempontjából. A következőkben egy ferde rétegződésü magon végzett folyadékfeltöltéses CT vizsgálat eredményeit mutatom be. A folyamatot több időpillanatban készült CT felvételek adataiból készült gridhálók, és azok korrelogramjai segítségével követhetjük nyomon. A Hounsfield egységek adatait tartalmazó gridhálón a feltöltés előrehaladása követhető nyomon, míg a korrelogram megmutatja, hogy a lattice-on belül az adatok mennyire korrelálnak egymással.

A CT mérések eredményeinek értelmezéshez három fontos általánosságot kell figyelembe vennünk:

- A törmelékes üledékes kőzetek esetében a Hounsfield értékek jól korrelálnak a térfogati sűrüséggel, az atomszámmal, a porozitással, a kőzet víztartalmával és a kémiai összetétellel (HUNT et al, 1998., BOESPLFLUG et al 1995.).

- A törmelékes üledékes kőzeteket vizsgálva a Hounsfield értékek értelmezése csak közel azonos korú és genetikájú (azonos vagy hasonló felhalmozódási folyamatok és - környezet) üledékek esetében adhat egzakt eredményeket (HUNYADFALVI Z. 2004, 2006), mivel a sugárgyengítési érték nagysága függ a kőzet korától.

- A Hounsfield érték függ a szövet durvaságától. Azonos korú és hasonló fejlődéstörténettel rendelkező kőzetek közül a finomabb szövet sugárgyengítési együtthatója magasabb, mint a durvább szemcseméretüé. (HUNYADFALVI Z. 2006)

A vizsgálati eredményeket a 7.2.1 fejezetben foglalom össze.

\subsubsection{A feltöltés fázisonkénti menete}

A töltődési folyamatot a 7-2. ábr segítségével követhetjük nyomon. A bal oldali grideken szürke színnel jelentkeznek azok a területek, melyek az adott időpillanatban a töltődési folyamatban nem vesznek részt. Az első fázisban az áramlás a gyengeségi zónák mentén indul meg. Ennek oka a pórusnyomás és a fluidumnyomás közötti nyomáskontraszt. A második fázisban egy egyenletesebb, fokozatos feltöltődés zajlik a homokosabb részeken, melyet a harmadik fázisban a fluidum mozgási frontjának megjelenése követ. A mozgási front előrehaladásának fázisai tükröződnek a harmadik, és a negyedik áramlási fázis gridjein, és korrelogramjain is. A befejező, ötödik fázisban már csak a „maradék”, kis nyomáskontrasztú üledékek, illetve azok pórusainak töltődése jelentkezik. 


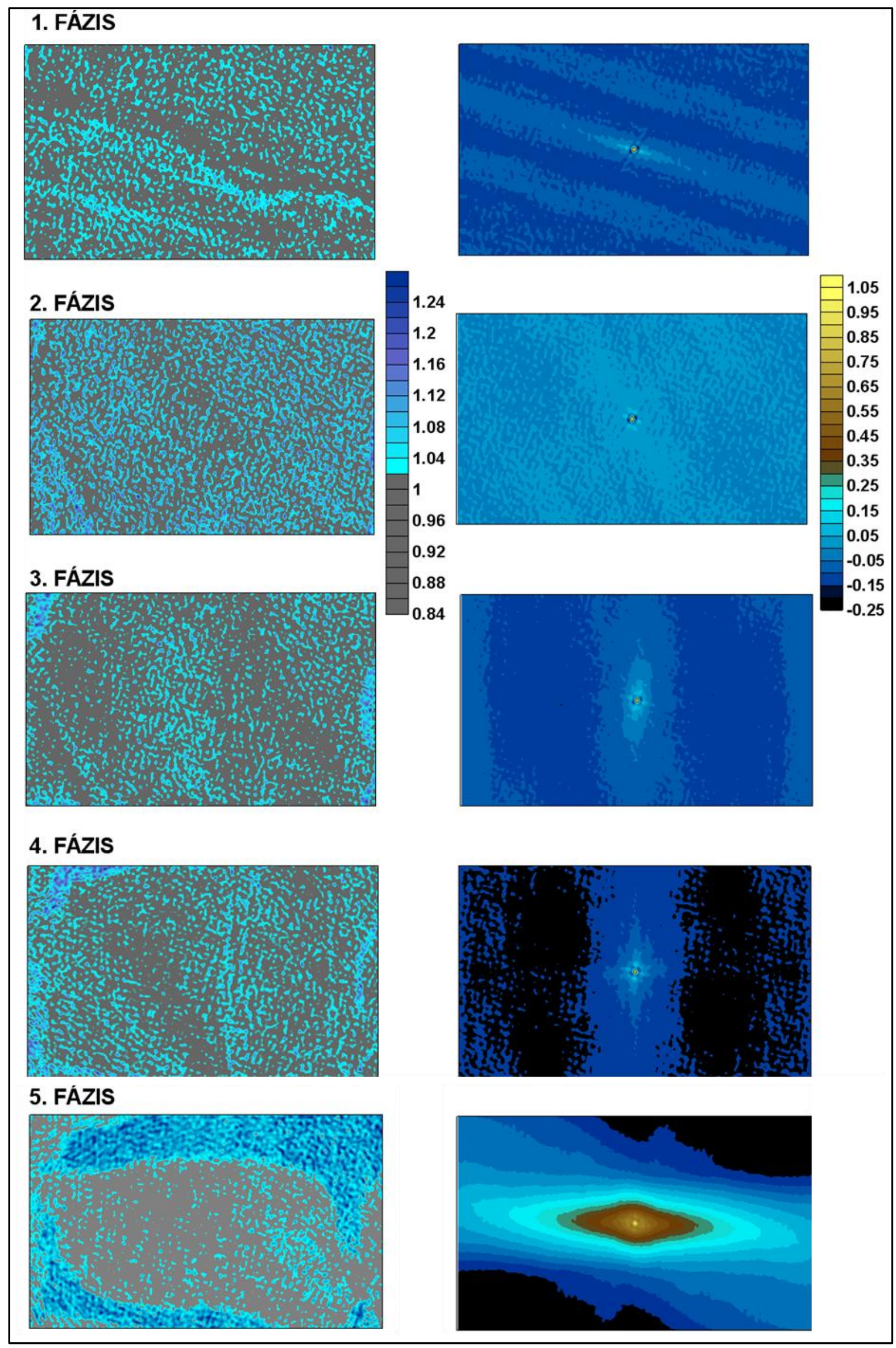

7-2. ábra Ferde rétegzödés egyfázisú áramlásos vizsgálatának CT felvételei alapján készült gridhálók (bal oldalon) és azok korrelogramjai (jobb oldalon) 


\subsubsection{A fluidum-áramlás heterogenitása}

A fluidum mozgási zónák és frontok térképezéséhez az adatokból egy vektoros kép előállítása történt. A vektortérkép vektorai a nagyobb HE értékekkel jellemezhető adatpont felől a kisebb HE értékü adatpont felé mutatnak, így irányuk kongruens a kőzetszövetben áramló fluidum mozgási útjának leképeződésével. A vektortérképhez tartozó színskálát 3 értéktartományra osztottam, mely tartományok megfelelnek az adott adatpont aktuális, fluidummal való töltöttségi fokozatának. A töltődési folyamat egyes szakaszaihoz tartozó vektortérképek ily módon a fluidum-áramlás heterogenitását is szemléltetik (7-3. ábra).
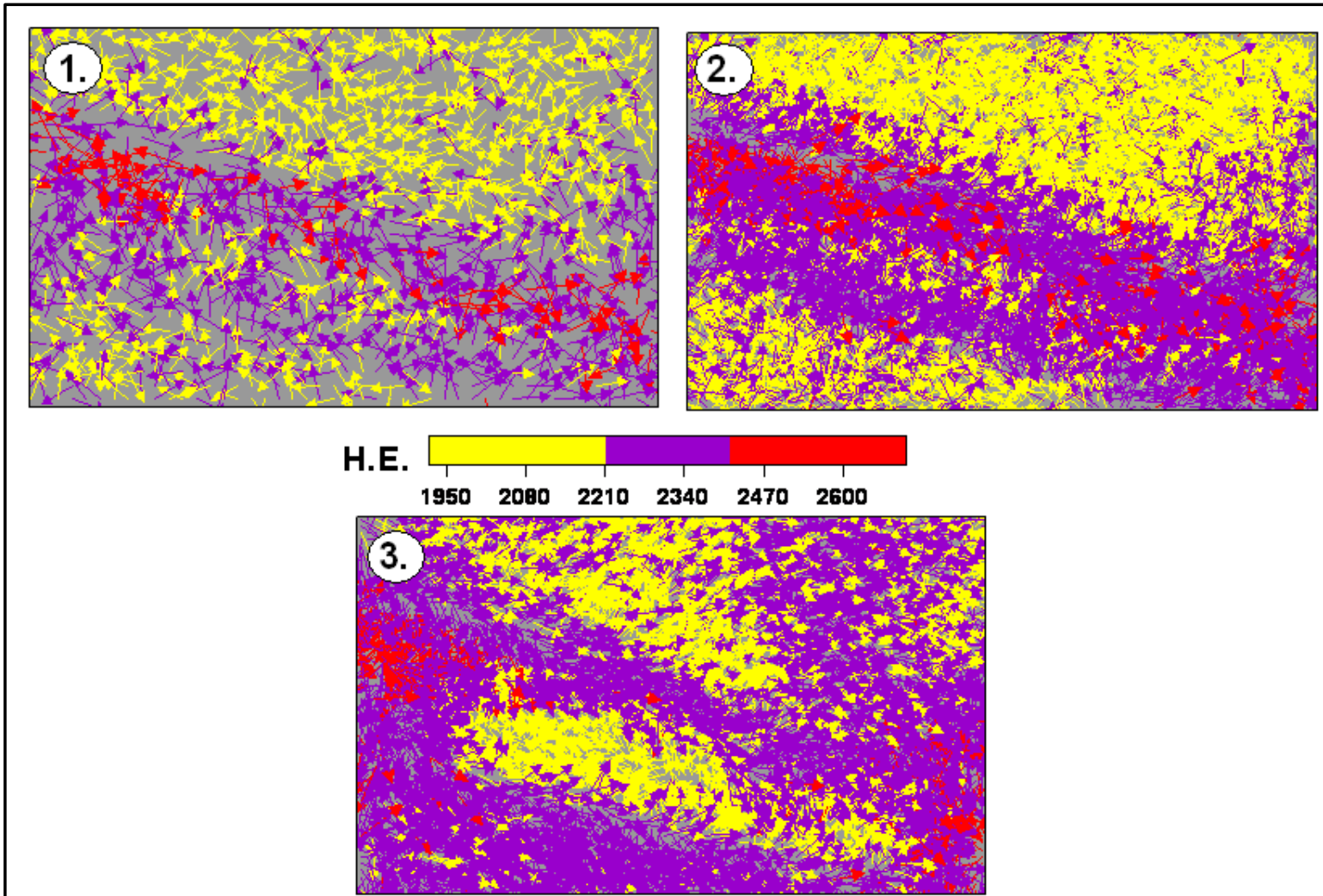

7-3. ábra A fluidummal való töltöttség 3 nagyobb mozgási szakaszának megfelelö vektortérképek

A vektortérképek alapján az alábbiakat állapíthatjuk meg:

- A fluidummal való töltődés 3 nagyobb mozgási szakaszra osztható;

- A rétegződésen belül az aleurit réteg féligáteresztő/ impermeábilis réteget képez;

- A kiszorítás a nagyobb nyomáskontraszttal rendelkező kőzetben hatékonyabban tud végbemenni, mivel a kőzet nyomáskontraszt szempontjából heterogén. A kellő nyomáskontraszt híján az invázió nem, vagy csak nehezen valósulhat meg;

- A nyomáskontraszt-szegény régiókban a by- passed olaj visszamaradásának lehetősége nő;

- A tárolás a homogén pórusnyomással jellemezhető kőzetekben jobb, míg a kiszorítás a heterogén pórusnyomású kőzetekben könnyebben valósul meg. 


\subsubsection{Az effektív porozitás heterogenitása}

A töltöttség előtti és a teljes feltöltődés utáni állapotok gridjeit összehasonlítva vizsgálható a fluidum-áramlásában résztvevő szöveti rész. Ennek segítségével az effektív porozitás bizonyos jellemzőit sikeresen közelíthetjük. A vizsgált kőzetrészlet töltődési folyamat előtti állapotának gridjét a 7-4. ábra mutatja.

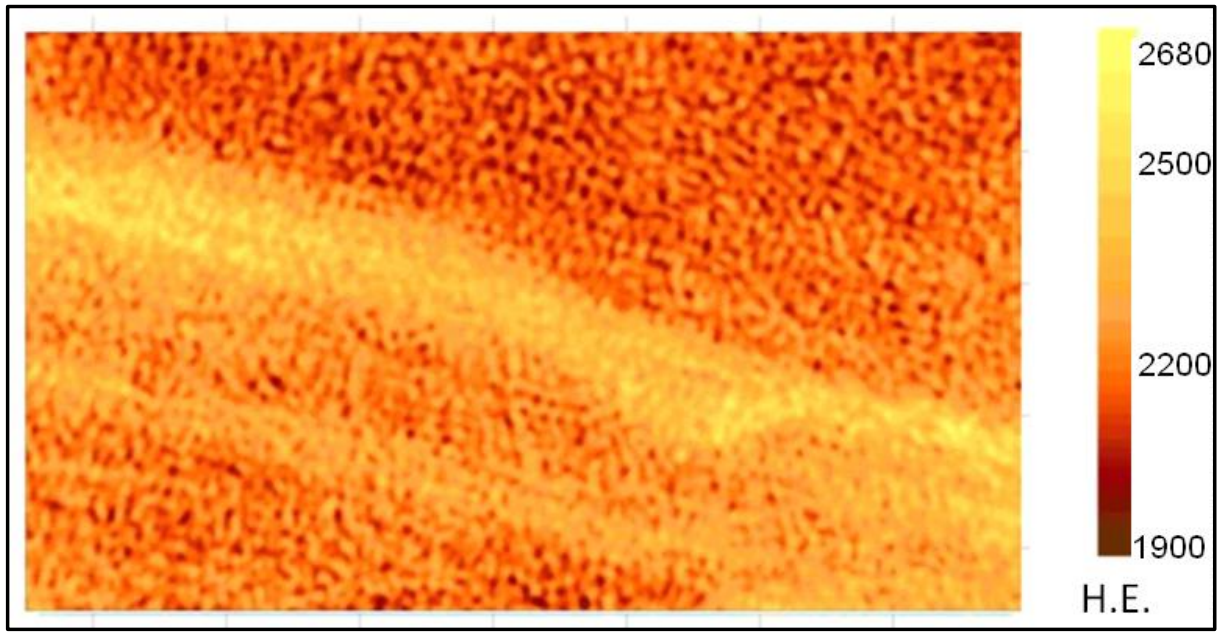

7-4. ábra A száraz állapot gridje

A magas H.E. értékek az aleuritosabb, míg az alacsony H.E. értékek a homokos kőzetrészeknek felelnek meg. A ferde rétegződés a griden jól kirajzolódik. A 7-5. ábra egy kompozit grid, alsó rétege a töltődési folyamat előtti szövet-állapotot mutatja, míg felső, kék színskálával ellátott gridje azokat a szövetrészeket, melyekhez tartozó H.E. értékek meghaladták a száraz állapotukhoz tartozó H.E. értéküket, azaz a teljes töltődés állapotában értékük magasabb volt, mint a kezdeti H.E. érték. A két ábra összehasonlításakor szembetünik, hogy a két eltérő kőzettípus határfelülete illetve szöveti része valóban részt vett a feltöltés folyamatában, míg az aleuritos réteg kevésbé, vagy egyáltalán nem töltődött fel.

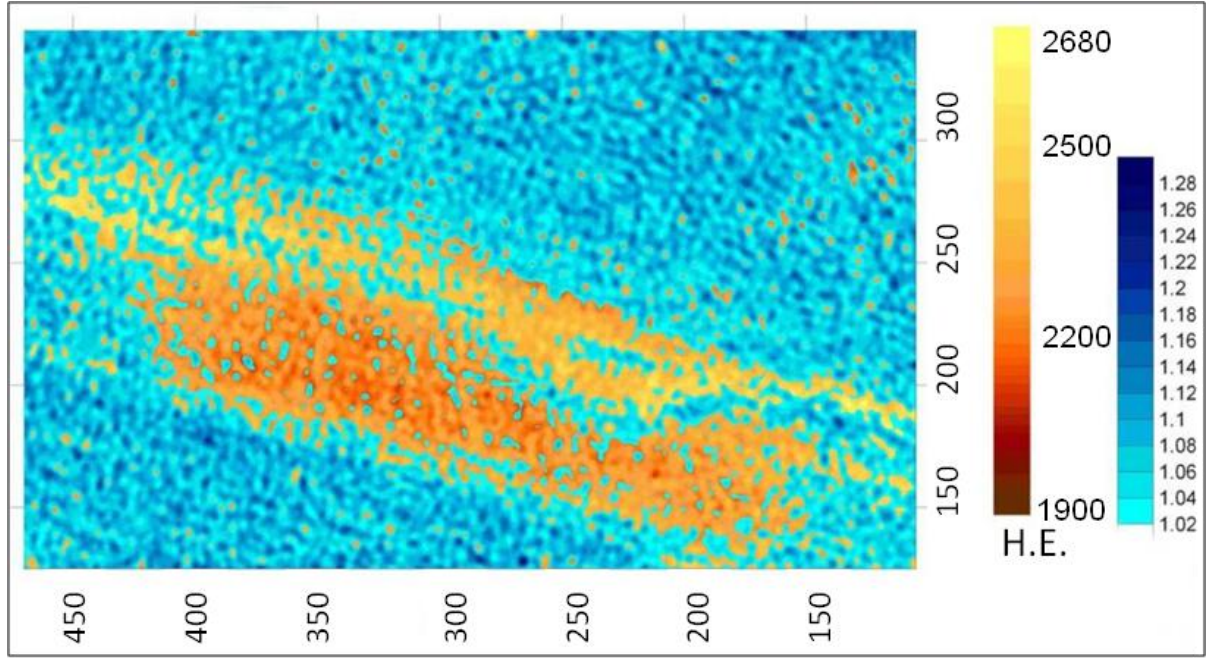

7-5. ábra A száraz és a teljes töltöttség állapotának kompozit gridje 
A 7-5. ábra alapján elkülöníthető az a rész is, mely a ferde rétegződés alatti magrészben nem töltődött fel annak ellenére, hogy felépítő kőzete inkább homokos, mint aleuritos, vagyis ez az a rész, ahol kellő nyomáskontraszt híján az invázió nem tudott megvalósulni. Az effektív porozitás heterogenitását a 7-6. ábra szemlélteti.

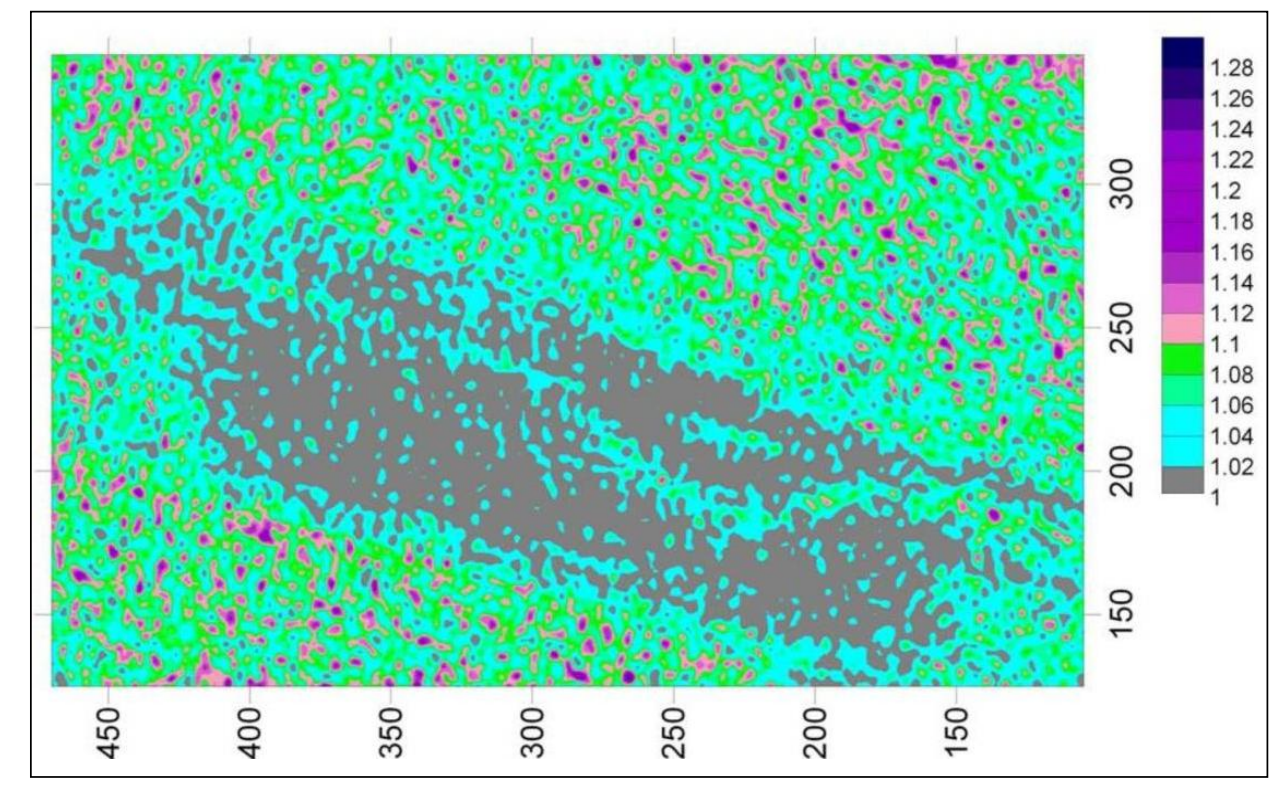

7-6. ábra Az effektív porozitás heterogenitása

A szürkével jelölt területek az effektív porozitás kiépítésében nem vettek részt, a hozzájuk tartozó HE értékek a feltöltés előtt és azt követően nem mutattak eltérést. A két eltérő kőzettípus határán az effektív porozitás 2-6\%. Ezek azok a részek, melyek a töltődési folyamat kezdetén a legelső „inváziós folyosók” módjára viselkedtek. A nagyobb effektív porozitás-értékekkel jellemezhető részek a feltöltésbe ezt követően kapcsolódtak be. A feltöltés legkésőbb a legmagasabb, 22-28 \%-os effektív porozitású részekben következett be.

A töltődési folyamat 3 szakaszában a töltődést adó H.E.-k box-plotjai alapján megállapítható, hogy a töltődés bármely fázisában minimum 200 H.E. különbség szükséges a töltődés sikerességéhez (IV-1. melléklet).

\section{3 Összeolvadási felszín vizsgálata CT-vel}

Az eróziós és összeolvadási felszín, mint szedimentológiai fogalmak eredetüket tekintve közel állnak egymáshoz. Pontos meghatározásuk azonban esetenként problémákba ütközhet. Az egzakt értelmezéshez Balogh K. kőzetszerkezetről és szövetről alkotott definícióit vettem alapul (BALOGH K. és MOLNÁR B, 1972). Ezek szerint kőzetszerkezet alatt „,a heterogén kőzet vagy kőzettest ama tulajdonságait értjük, amelyekben a szomszédos kőzetrészletek vagy kőzettestek szöveti vagy összetételbeli különbségei tükröződnek”. A szövet ,,a homogén kőzet 
vagy ásvány aggregátum azon makro vagy mikroszkópos sajátsága, amit annak kristályossági foka, szemcséinek vagy egyéb alkotórészeinek alakja és egymáshoz való viszonya alakít ki. ” (BALOGH K. és MOLNÁR B, 1972). A fenti meghatározások, és RICCI LUCCHI, F.(1995) az eróziós felszín természetéről alkotott elképzelése alapján a két felszín genetikáját összehasonlítva elmondható, hogy mindkettő eróziós eredetű. A kettő közötti különbség a diszkontinuitás jellegéből és természetéből adódik. Az összeolvadási felszín rétegen belüli diszkontinuitásként értelmezhető, mely esetben az eróziót két azonos vagy hasonló kőzettípus összeolvadása okozza (RICCI LUCCHI, F. 1995), az eróziós felszín viszont rétegek közötti diszkontinuitást jelent. Ebből adódóan az első esetben egy szöveti jellegzetességgel, a második esetben üledékszerkezeti jeggyel állunk szemben.

Összegezve, az összeolvadási felszín egy olyan, a szöveti elrendeződésben bekövetkezett változás, mely kizárólag a felhalmozódással egyidejü, szinkron folyamatok által alakul ki. Ezzel szemben az eróziós felszínt a két eltérő kőzettípus közötti fokozatos átmenet hiánya alakítja ki.

MATTERN F. tanulmányában (MATTERN, F. 2002) az összeolvadási felszínt két turbidit közötti eróziós kapcsolat eredményének tekinti, mely az egyértelmü lefejeződés jele. Mattern szerint legtöbb esetben az összeolvadási felszín alatt homokot, felette pedig durvaszemü homokot, illetve aprószemű kavicsot találunk. Csak kevés esetben jelenik meg az összeolvadási felszín alatt és fölött is homok.

Az összeolvadási felszín szöveti tulajdonságának vizsgálata során megállapítottam (SEBÖK SZ., 2006, 2008), hogy a pannóniai korú mintákon végzett CT vizsgálatok alapján az eróziós és az összeolvadási felszín egymástól jól elkülöníthető. Az utóbbi esetében a CT adatok numerikus vizsgálata alapján az üledékes szövetet csak a szedimentációs folyamatok határozták meg. Az összeolvadási felszínt kialakító folyamat hatása az összeolvadási felszín fölött a közepes szemcsetartományban jelentkezik. Mivel az összeolvadási felszín a folyóvízi delta üledékekben gyakori szöveti bélyeg, a 8.3.1. fejezetben megvizsgálom annak lehetséges hatását egy feltételezett folyadékáramlásra.

\subsubsection{Az összeolvadási felszín lehetséges hatása a fluidum áramlásokra}

Az összeolvadási felszín fluidum-áramlásokra való lehetséges hatásait a Laplaceoperátor segítségével vizsgáltam (Surfer 8.0). Az egyenletben előforduló Laplace operátor $\left(\nabla^{2}\right)$ egy differenciál operátor. Egy felszínt vizsgálva megadja az áramlás és az elnyelődés mértékét. Az áramlási területek pozitív, míg a gyüjtő területek negatív értékkel jelentkeznek. A Laplace operátor által szolgáltatott eredmény számszerüsíti, hogy adott fizikai feltételek mellett a gridhálón belüli áramlásra hatással van- e egy helyi befolyásoló tényező, vagy sem: 


$$
\nabla^{2} Z=\frac{\partial^{2} Z}{\partial x^{2}}+\frac{\partial^{2} Z}{\partial y^{2}}
$$

Ebben az esetben a $Z$ a vizsgált tulajdonság (jelen esetben a Hounsfield értékek), $x$ és y mérési pontok távolsága az adatmátrixban x illetve y irányban (koordinátapontok). Ezt a Surfer egy általános, ötváltozós formulából számított griddel egészíti ki, melyben a koordináták numerikusan az alábbi képlet segítségével számolhatók:

$$
\nabla^{2} Z x, y=\frac{Z_{E}-2 Z+Z_{W}}{\Delta x^{2}}+\frac{Z_{n}-2 Z+Z_{s}}{\Delta y^{2}}
$$

ahol $\mathrm{Z}, \mathrm{Z}_{\mathrm{E}}, \mathrm{Z}_{\mathrm{W}}, \mathrm{Z}_{\mathrm{S}}, \mathrm{Z}_{\mathrm{n}}$ öt vizsgált tulajdonságot jelöl.

A minta vizsgált, $20 \mathrm{~cm}$ magas, hossztengely menti metszeti részletének fényképét, normál CT-képét és Surferben megjelenített gridhálóját a 7-7. ábra szemlélteti.

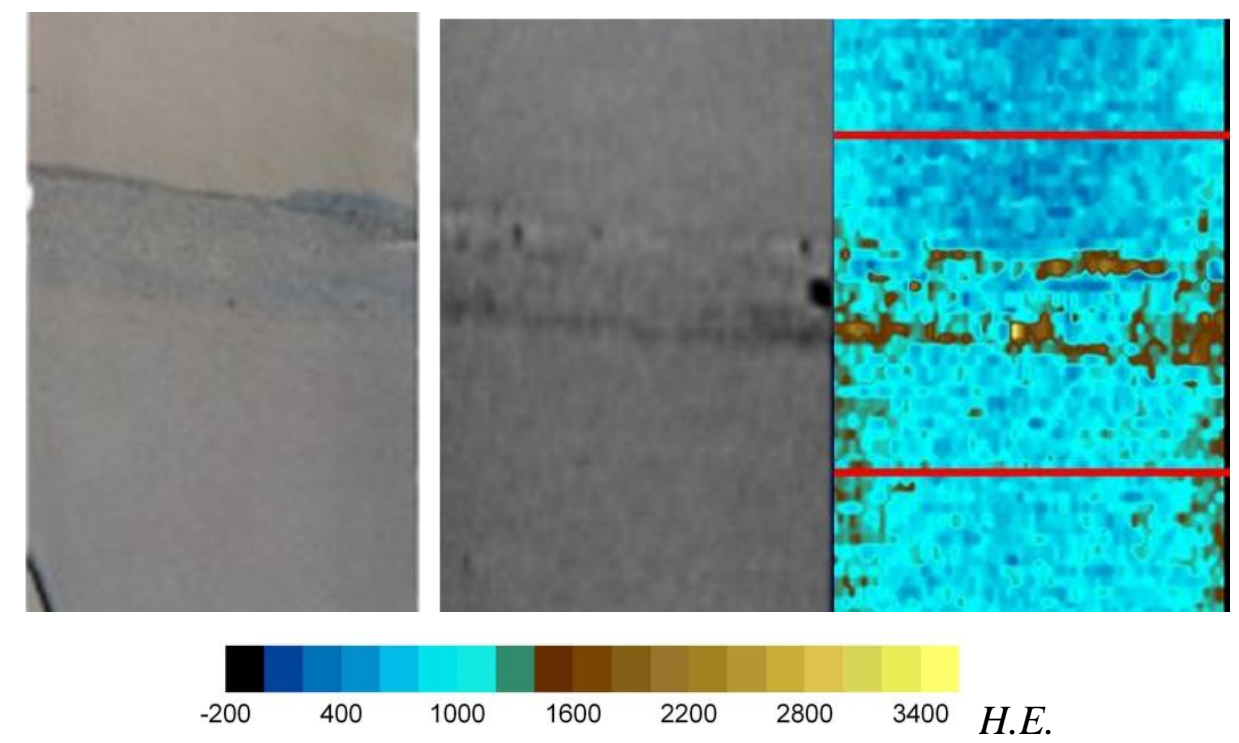

7-7. ábra Az összeolvadási felszint tartalmazó magminta fényképe, CT-képe és Surferben megjelenitett gridje

A vizsgálathoz 6 darab, a magtengelyre merőleges szeletet választottam ki, kettőt- kettőt az összeolvadási felszín alatt, fölött, és az összeolvadási felszín mentén. A 7-8. ábra az összeolvadási felszínnek egy feltételezett horizontális irányú fluidum-áramlásra gyakorolt lehetséges hatását mutatja be. A statikus áramlási képeken kék színnel rajzolódnak ki azok a területek, ahol egy feltételezett áramlás akadálytalanul végbemehet, feketével pedig a szétáramlási területek. Az áramlási pályák az összeolvadási felszínen határozottabban jelentkeznek, mint az összeolvadási felszín alatti és feletti részben. 


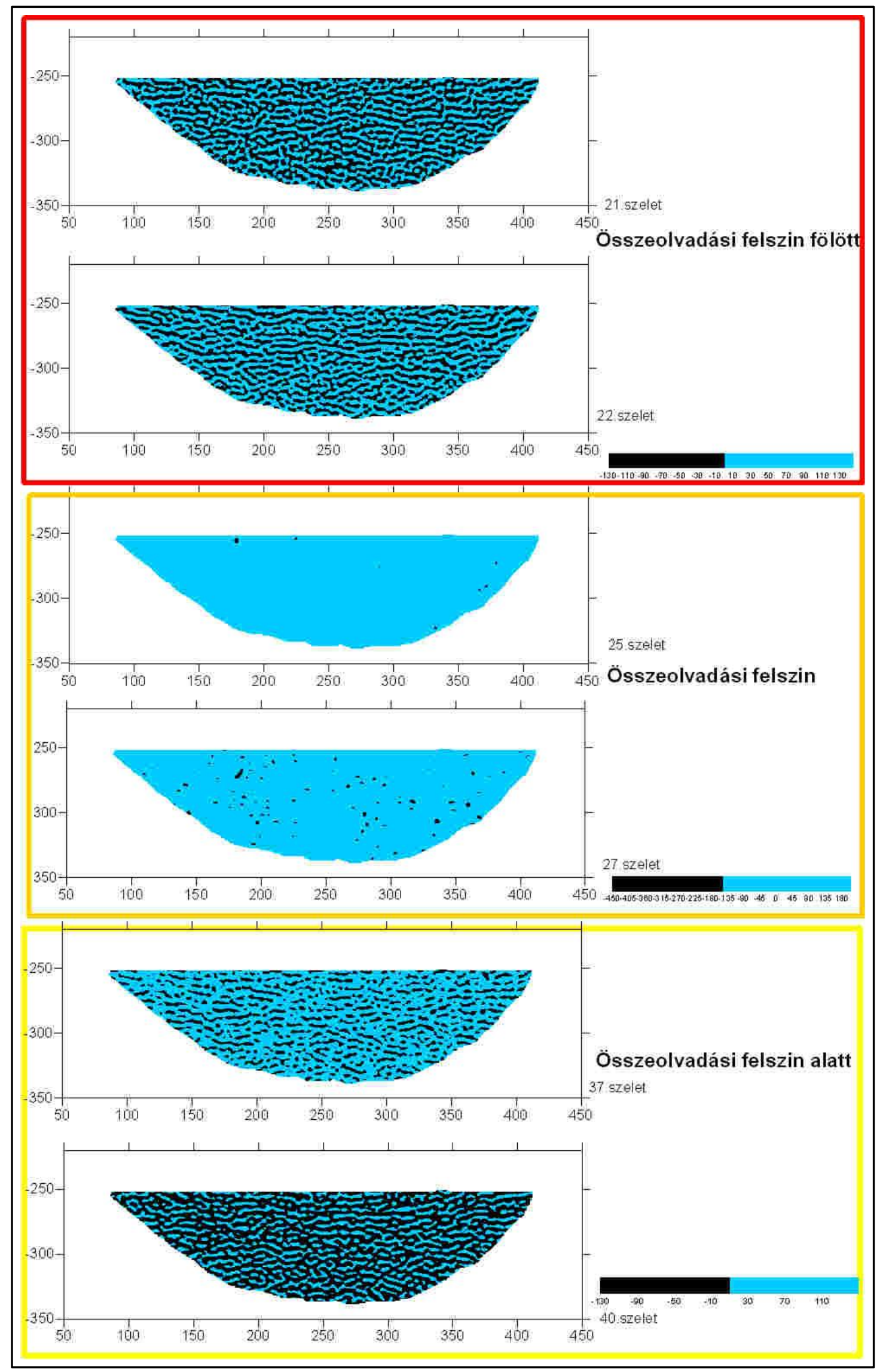

7-8. ábra Az összeolvadási felszín lehetséges hatása a kisléptékü laterális fluidum áramlásokra 
A vertikális irányú folyadékmozgásra gyakorolt hatás vizsgálatát a magtengellyel párhuzamos irányú metszeten végeztem. Miután a tengellyel párhuzamos metszet a tengelyre merőleges metszetek egyesítésével, és az így kapott magtérfogat tengellyel párhuzamos síkban való elmetszésével készült, a tengellyel párhuzamos metszeten alkalmazott gradiensvektor-illesztéses módszer, melyet a felszívásos vizsgálat esetében használtam, téves eredményt adna, ezért helyette a Laplace formulát használtam. A statikus áramlási képen (7-9. ábra) azok a szöveti részek, ahol a folyadékmozgás lehetősége fennáll, sárga színnel jelentkeznek, míg a gyüjtő területek, ahol áramlás nem történik, fekete színnel rajzolódnak ki.

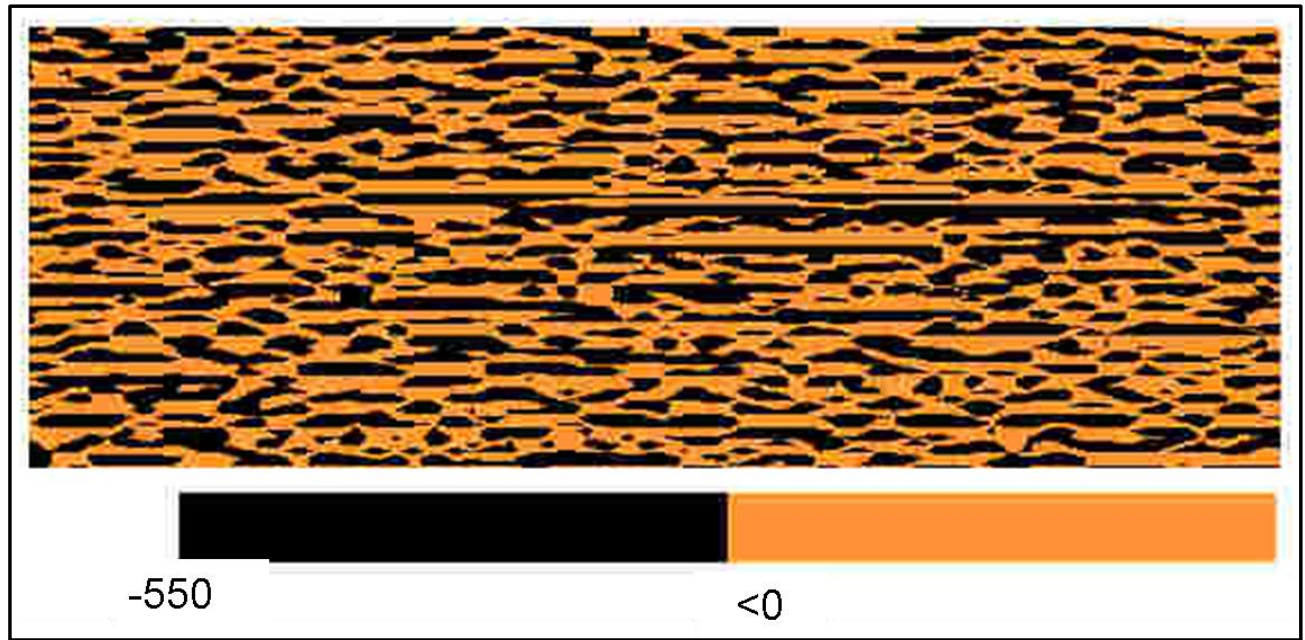

7-9. ábra Laplace egyenlet alapján elöállitott statikus áramlási kép (Surfer 8.0)

Röviden összefoglalva, a ferde rétegződésű kőzetmintát felszívásos CT vizsgálatnak alávetve, a nedvesítő, egyfázisú áramlások tekintetében megállapítható, hogy a feltöltő folyamat kezdetén a vékonyabb laminák is jelentősen vezetnek. Az egész mag vezető közegnek fogható fel, de némiképp a töredezett közegekre jellemző vezető tulajdonságokat mutat. A fluidum általi kisöprés egy folyadékfront kialakulása által valósul meg, melynek elöre haladása akkor lehetséges, ha a fluidum nyomása meghaladja a pórustér nyomását.

A töltődési folyamat 3 szakaszában a töltődést adó HE egységek box plotjai alapján megállapítottam, hogy a töltődés bármely fázisában, minimum 200 HE különbség szükséges a töltődés sikerességéhez

Az összeolvadási felszín kis mértékben lassíthatja a vertikális irányú fluidum áramlásokat, melynek mértéke a felszín vertikális kiterjedésének a felépítő kőzet szemcseparamétereinek, függvénye. 


\section{Makrolépték: a szöveti és kőzetfizikai kapcsolatok}

\subsection{A kőzetszövet és a kőzetfizikai tulajdonságok közötti kapcsolat}

A kőzetfizikai és szöveti tulajdonságokat feltáró kismag kőzetfizikai mérések a térfogatsúly, a porozitás, a kL ekvivalens permeabilitás és a folyadék permeabilitás mérését célozták meg. A kőzetfizikai tulajdonságok kőzettípusonkénti fő statisztikai jellemzőit a 8-1. táblázat foglalja össze. A kőzetfizikai tulajdonságok kapcsolatának grafikonjait az V-1. - V-3. melléklet tartalmazza.

A homokkövek porozitása és függőleges illetve vízszintes irányban mért folyadékekvivalens permeabilitása között erös, exponenciális kapcsolat van. Mindkét permeabilitás nő a porozitás növekedésével ( $\mathbf{V}-1$. melléklet, $\mathbf{A}$ és $\mathbf{B})$.

Homokkövek estében a porozitást az agyagtartalom és a kalcittartalom rontja (V-1. melléklet $\mathbf{C}$ és D), míg a dolomittartalommal való kapcsolata (V-1. melléklet E) nem lineáris, nehezen meghatározható, így valószínűleg a porozitást az esetek túlnyomó többségében érdemben nem befolyásolja.

Permeabilitás tekintetében elmondható, hogy a vízszintes irányú permeabilitást szintén a kalcittartalom növekedése rontja+agyagtart (V-1. melléklet $\mathbf{F}$ és $\mathbf{G})$. A dolomittartalom szerepe itt is alárendelt (V-1. melléklet $\mathbf{H})$. A függőleges permeabilitást az agyagtartalom és a kalcittartalom negatív irányban befolyásolja (V-2. melléklet A és B). A dolomittartalommal való kapcsolata sem karakteres (V-2. melléklet C).

\begin{tabular}{|c|c|c|c|c|c|}
\hline TULAJDONSÁG & STATISZTIKA & $\begin{array}{c}\text { APRÓ- } \\
\text { HOMOK- } \\
\text { KÖ } \\
\end{array}$ & $\begin{array}{c}\text { FINOM- } \\
\text { HOMOKKŐ }\end{array}$ & $\begin{array}{c}\text { APRÓ ÉS } \\
\text { FINOM HKÖ }\end{array}$ & ALEUROLITOK \\
\hline \multirow{5}{*}{ POROZITÁS } & Minimum & 0,26 & 0,28 & 0,26 & 0,20 \\
\hline & Maximum & 0,34 & 0,31 & 0,34 & 0,32 \\
\hline & Középérték & 0,31 & 0,29 & 0,31 & 0,27 \\
\hline & Szórás & 0,02 & 0,01 & 0,02 & 0,03 \\
\hline & Eloszlás & Lognormál & k.a. & Erlang & Extr.érték \\
\hline \multirow{5}{*}{$\begin{array}{l}\text { FÜGGÖLEGES } \\
\text { PERMEABILITÁS } \\
\text { (KLf) }\end{array}$} & Minimum & 10,08 & 56,21 & 10,08 & 0,22 \\
\hline & Maximum & 4377,46 & 530,71 & 4377,46 & 1682,29 \\
\hline & Középérték & 1067,13 & 289,01 & 1012,83 & 231,65 \\
\hline & Szórás & 890,15 & 237,37 & 882,43 & 500,6 \\
\hline & Eloszlás & Lognormál & k.a. & Erlang & Lognormál \\
\hline \multirow{5}{*}{$\begin{array}{c}\text { VÍZSZINTES } \\
\text { PERMEABILITÁS } \\
\text { (KLv) }\end{array}$} & Minimum & 154,89 & 448,47 & 154,89 & 0,57 \\
\hline & Maximum & 4861,94 & 773,36 & 4861,94 & 1726,31 \\
\hline & Középérték & 1611,07 & 563,81 & 1538,01 & 352,38 \\
\hline & Szórás & 1008,78 & 181,77 & 1009,65 & 576,59 \\
\hline & Eloszlás & Laplace & k.a. & Lognormál & Lognormál \\
\hline
\end{tabular}

8-1. táblázat A közetfizikai tulajdonságok kapcsolata

Mivel a petrofizikai tulajdonságokat célzó mintavételezés elsősorban a jobb kifejlődésű, homokosabb magrészeket célozta, az aleuritos minták adatainak analízise nem reprezentatív, így csak tájékoztató jelleggel közlöm. 
Az aleuritok porozitását az agyagtartalom negatív irányban (V-2. melléklet D), míg a dolomittartalom pozitív irányban befolyásolja (V-2. melléklet E). A porozitás és a kalcittartalom közötti kapcsolat nehezen meghatározható (V-2. melléklet F), de mivel a porozitás és az összkarbonát- tartalom kapcsolatának vizsgálati eredménye szerint a karbonáttartalom növekedésével az aleurolitok porozitása nő (V-2. melléklet G), valószínüsíthetjük, hogy a kalcittartalom valóban csak alárendelt szerepet játszik a porozitás tekintetében.

A vízszintes permeabilitást az agyagtartalom rontja (V-3. melléklet A), a dolomittartalom növeli (V-3. melléklet B). A függőleges permeabilitást az agyagtartalom a rendelkezésre álló mérési eredmények alapján érdemben nem befolyásolja (V-3. melléklet C). Az összkarbonát tartalom és a dolomittartalom, valamint a függőleges permeabilitás között gyenge kapcsolat van (V-3. melléklet $\mathbf{D}$ és $\mathbf{E})$.

\subsubsection{Porozitásmérések}

A vizsgálatok döntő hányada a nagyobb porozitású - 0.25-nél nagyobb porozitású- és permeabilitású apróhomokkő mintákon zajlott. A porozitás és a térfogatsúly értékek esetében a számtani átlag és a csonkított átlag hasonlósága azt mutatja, hogy a kiugró értékek az átlagok megítélését érdemben nem befolyásolják.

A kétféle porozitás adatsor összehasonlításakor az eloszlások kvantiliseit vizsgálva azt találjuk, hogy a két porozitás értékei egymáshoz közeli értékeket vesznek fel, a regressziós egyenesre igen jól illeszkednek. Jelentősebb eltéréseket csak a 22\%-os porozitás alatti értékek mérési eredmények jeleznek (8-1. ábra)

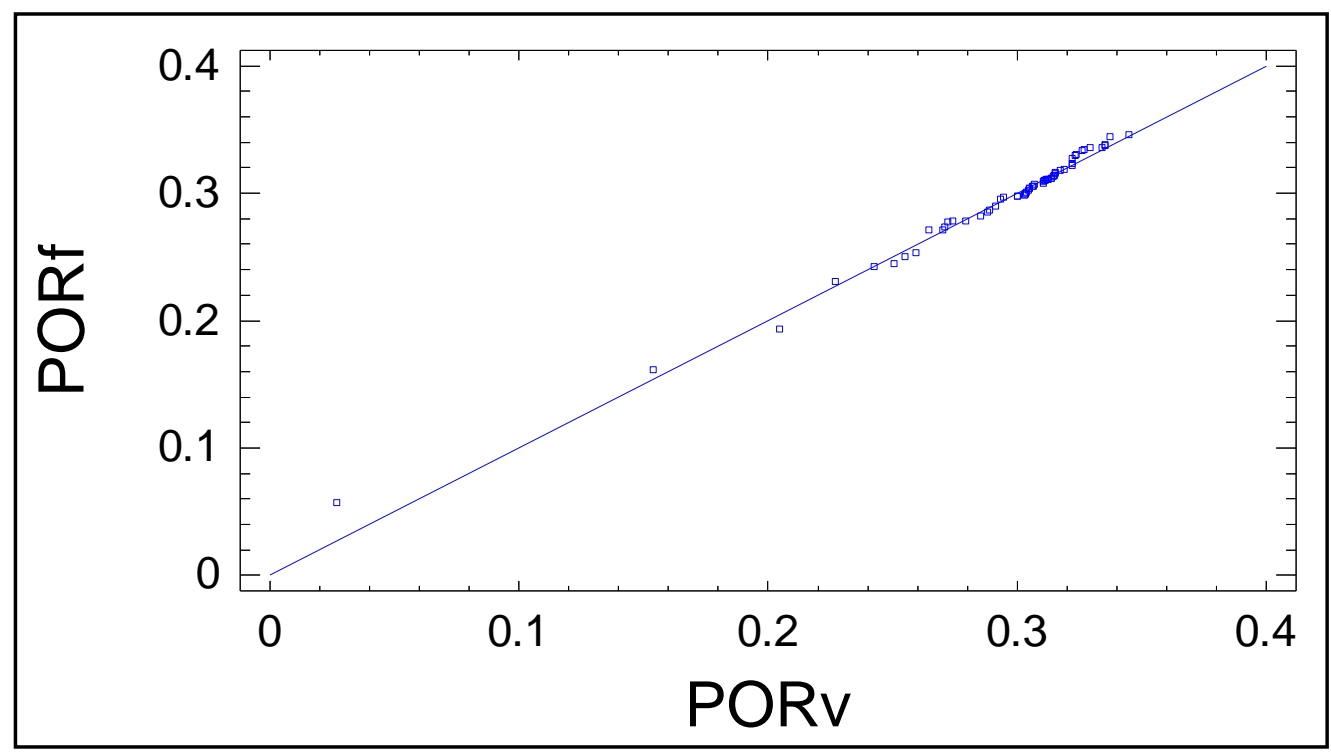

8-1. ábra A vizszintes és függöleges porozitás kapcsolata 
A mérési eredmények eloszlását vizsgálva és az adatokat box-ploton ábrázolva látható, hogy a kiugró és extrém értékeket mindkét méréstípus esetében majdnem ugyanazok a minták alkotják. Ugyanazon két agyagmárga és két finom aleurolit minta mindkét esetben extrém illetve kiugró értékként szerepel, és egy durva aleurolit minta, amely csak a vízszintes porozitásnál mutat kiugró értéket (8-2. ábra). Az eloszlásokat gyakorisági hisztogramon ábrázolva is szembetűnő a két adatsor szinte teljes egyezése (8-2. ábra).

A fentiek ismeretében kijelenthető, hogy statisztikai értelemben a két mért tulajdonságot egyként kezelhetjük, mivel egyik sem hordoz többlet információt a másikkal szemben. A továbbiakban ezért a vízszintes és függőleges porozitás számtani átlagát használtam a statisztikai kiértékelések során.
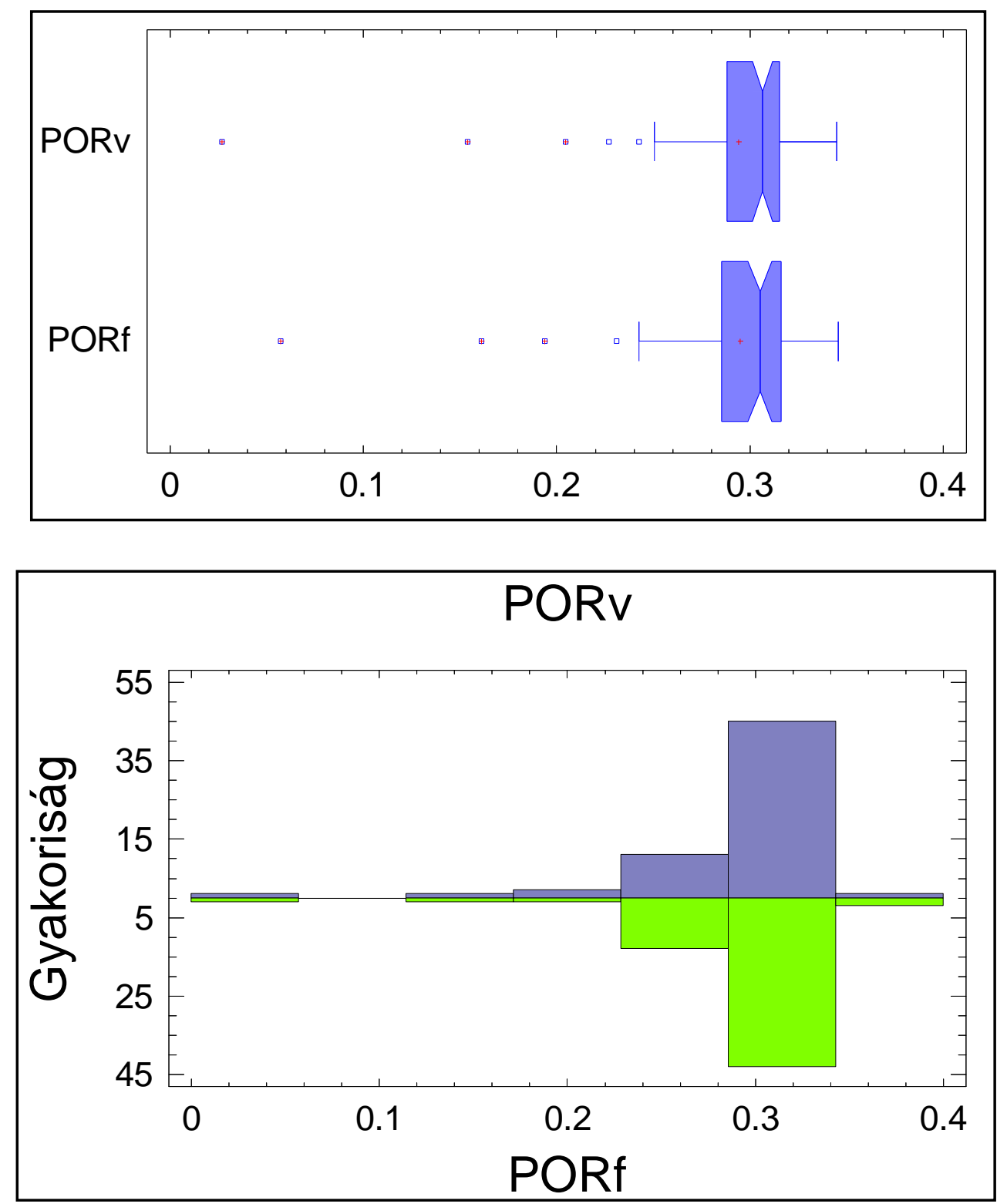

8-2. ábra A vizszintes és függőleges porozitások box-plotjai és gyakorisági hisztogramjai 


\subsubsection{A folyadékos és $k L$ ekvivalens permeabilitások összehasonlítása}

A porozitásokhoz hasonló egyezés a permeabilitásokkal kapcsolatban nem állapítható meg (8-3. ábra). A kL ekvivalens permeabilitások a folyadékos permeabilitás értékeknek csaknem a kétszeresét mutatják, azonban a kétféle permeabilitás anizotrópiája nagyon hasonló (GEIGER J.-. SEBÖK SZ., 2008).
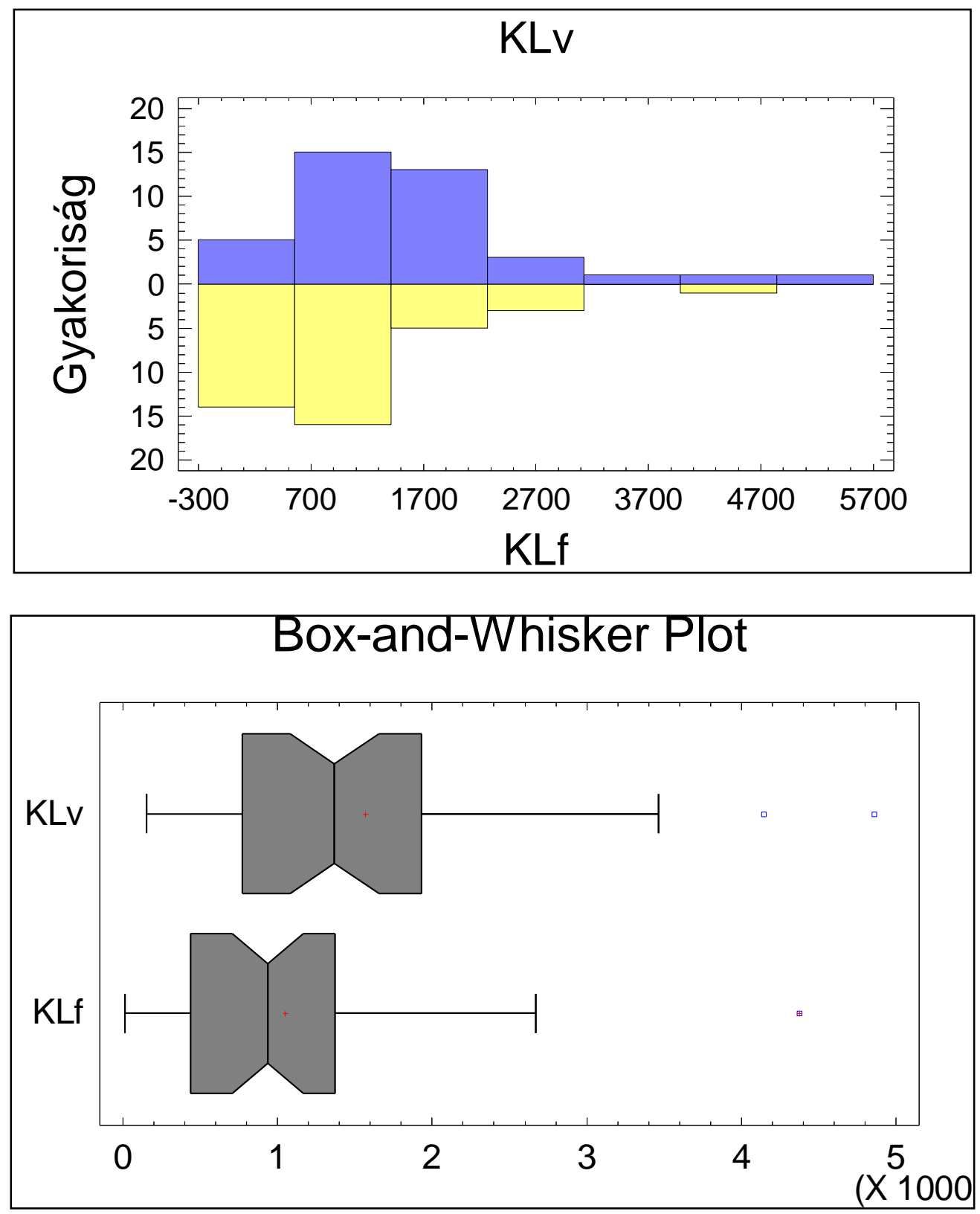

8-3. ábra A KLv és KLf gyakorisági hisztogramjai és box-plotjai 


\subsubsection{A vízszintes és függőleges $k L$ ekvivalens permeabilitások}

A vízszintes irányban mért $\mathrm{kL}$ ekvivalens permeabilitás esetében, 15 osztályközt vizsgálva három módust állapíthatunk meg. Az első fö módus a $325 \mathrm{mD}$ alatti permeabilitással, a második legnagyobb módus az 1625-1950 mD közötti permeabilitással bíró mintákat, végül a harmadik módus a 650 és $975 \mathrm{mD}$ közötti permeabilitású mintákat tömöríti (8-4. ábra).

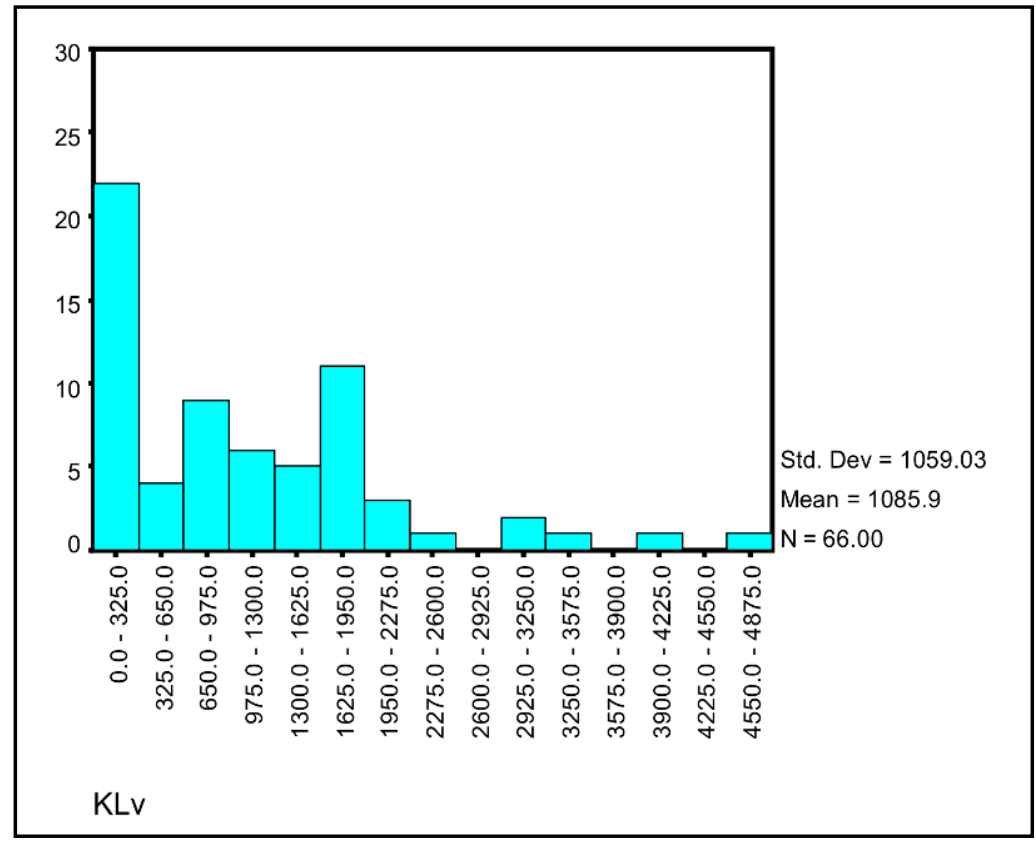

8-4. ábra A vízszintes KL ekvivalens permeabilitás gyakorisági hisztogramja

66 mintát vizsgálva az egyetlen kiugróan magas érték egy mederáttörési lóba felhalmozódásaként kialakult apróhomokkő minta (8-5. ábra).

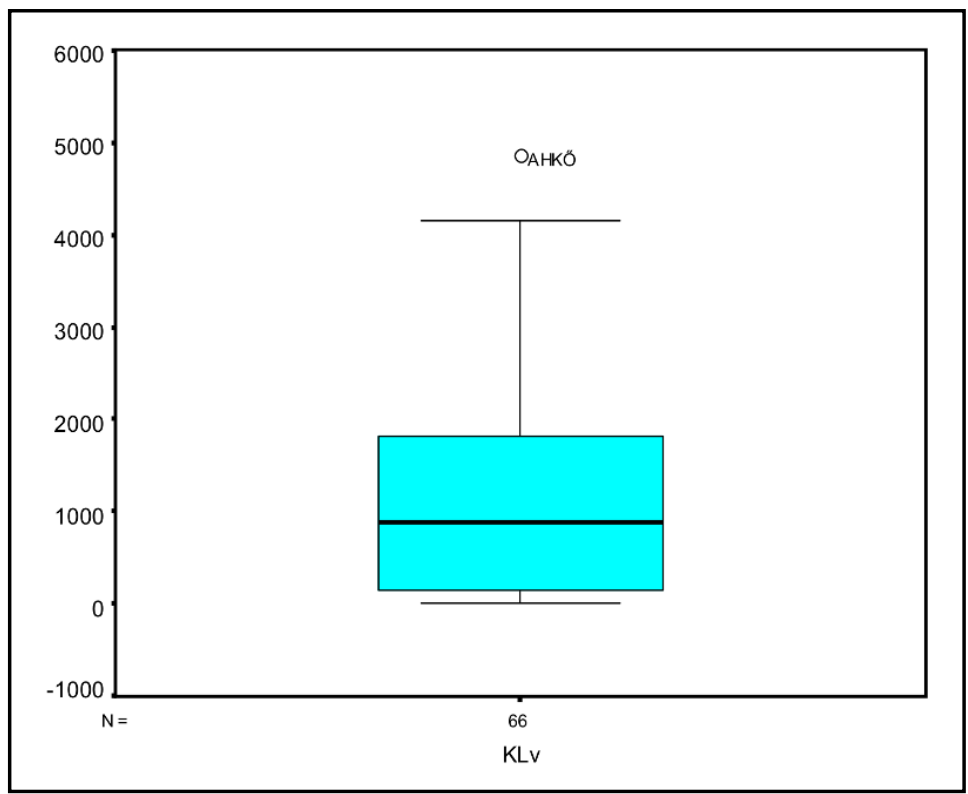

8-5. ábra A vizszintes KL ekvivalens permeabilitás értékek box-plotja 
A függőleges irányban mért $\mathrm{kL}$ ekvivalens permeabilitások két módusú eloszlást mutatnak, mely a homokkövek meder-mederáttörési lóba kettős genetikáján alapulhat (8-6. ábra). Kiugró értéket a KLv esetében is egy mederáttörési lóbából származó apróhomokkő minta szolgáltat (8-7. ábra).

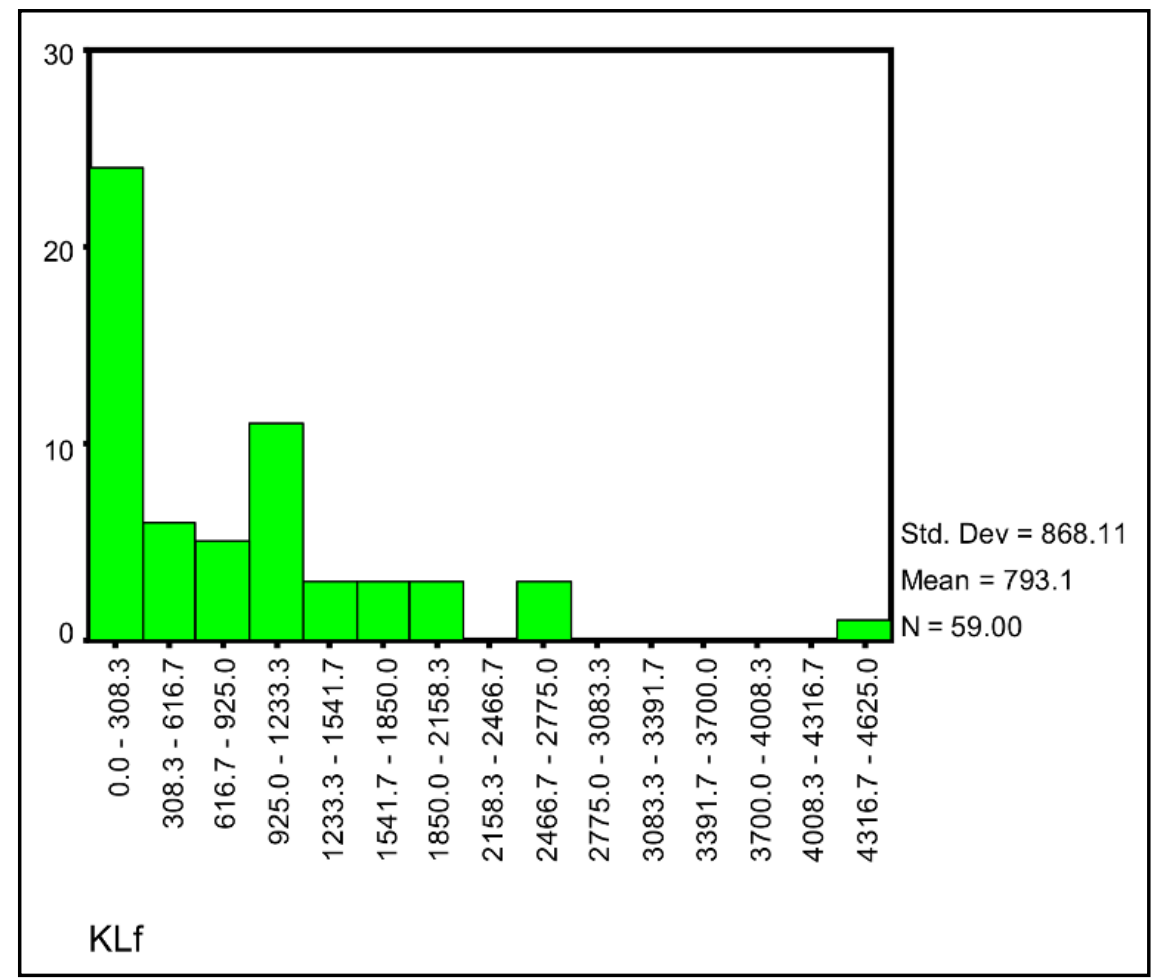

8-6. ábra A függöleges KL ekvivalens permeabilitás gyakorisági hisztogramja

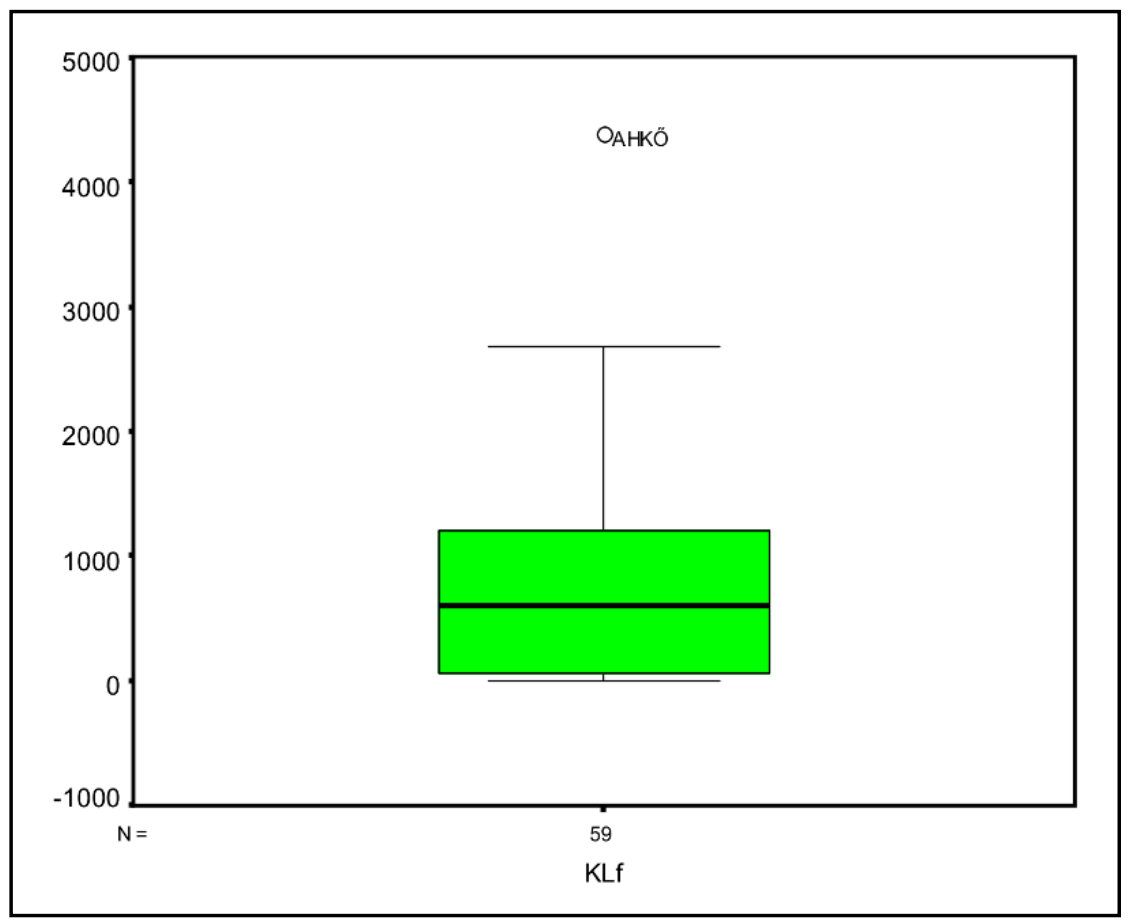

8-7. ábra A függöleges KL ekvivalens permeabilitás értékek box-plotja 


\subsubsection{A porozitás és a KLv kapcsolata}

A két tulajdonságra illesztett exponenciális regresszióban (8-8. ábra) a porozitás a vízszintes ekvivalens permeabilitás értékek varianciájának $87.3775 \%$ át írja le. A becslés átlagos abszolút hibája $0.71 \mathrm{mD}$. A regresszió egyenlete:

$$
K L v=\exp (-9.39461+52.3083 * \text { Poroz })
$$

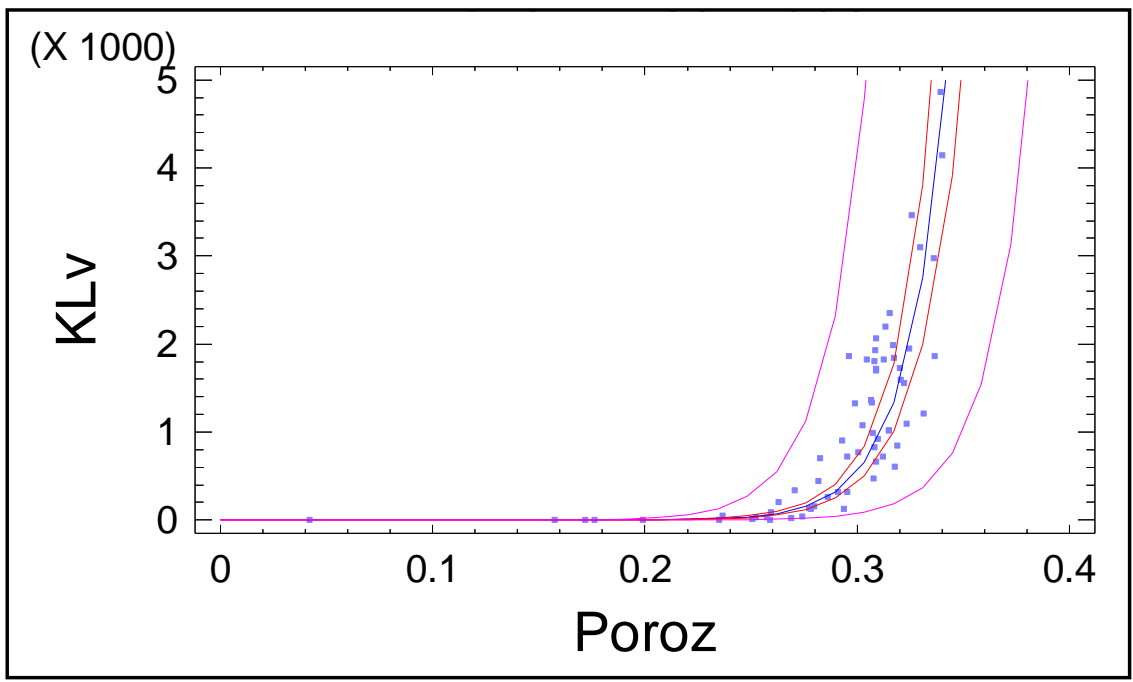

8-8. ábra A porozitás és a KLv kapcsolata

\subsubsection{A porozitás és a KLf kapcsolata:}

A függőleges permeabilitás a vízszinteshez képest kevésbé szoros kapcsolatot mutat a porozitással, de a két tulajdonság közötti kapcsolat még így is jelentős (8-9. ábra). A porozitás a függőleges permeabilitás varianciájának 71.11\%-át írja le. A becslés átlagos abszolút hibája $1.62 \mathrm{mD}$. A regressziós függvény a porozitás intervallumában:

$$
K L f=\exp (-10.7194+53.7826 * \text { Poroz })
$$

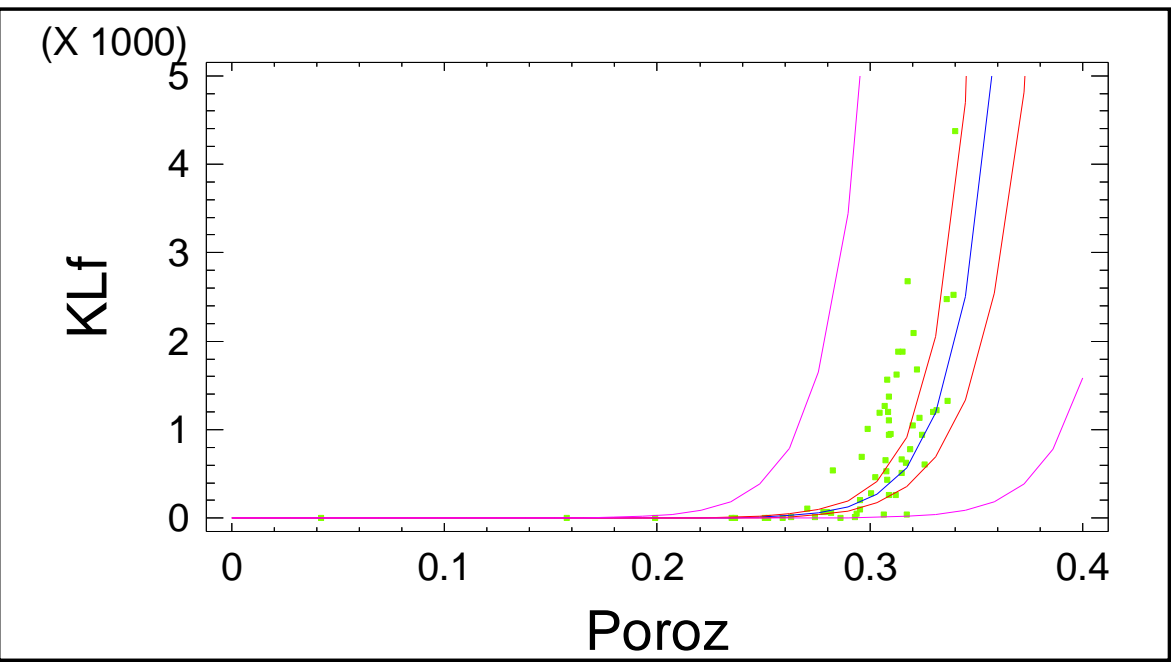

8-9. ábra A porozitás és a KLf kapcsolata 


\subsection{A kismag mérések tulajdonságainak kőzettípusonkénti jellemző értékei}

Mivel a teljes maganyagból a kismag mérésekhez választott minták néhány kivételtől eltekintve a jobb kifejlődésű homokkövek közül kerültek ki, az egyéb kőzettípusokba sorolható minták száma nem érte el a statisztikai értékelhetőséghez szükséges minimumot. Így e fejezetben csak a homokkő minták jellemző kőzetfizikai tulajdonságait mutathatom be.

\subsubsection{Homokkövek porozitása}

A homokkövek porozitásának gyakorisági eloszlását vizsgálva megállapítható, hogy a hisztogram egy módusú. Fő módusa a $31 \%$ porozitásértékek körül jelentkezik (8-10. ábra).

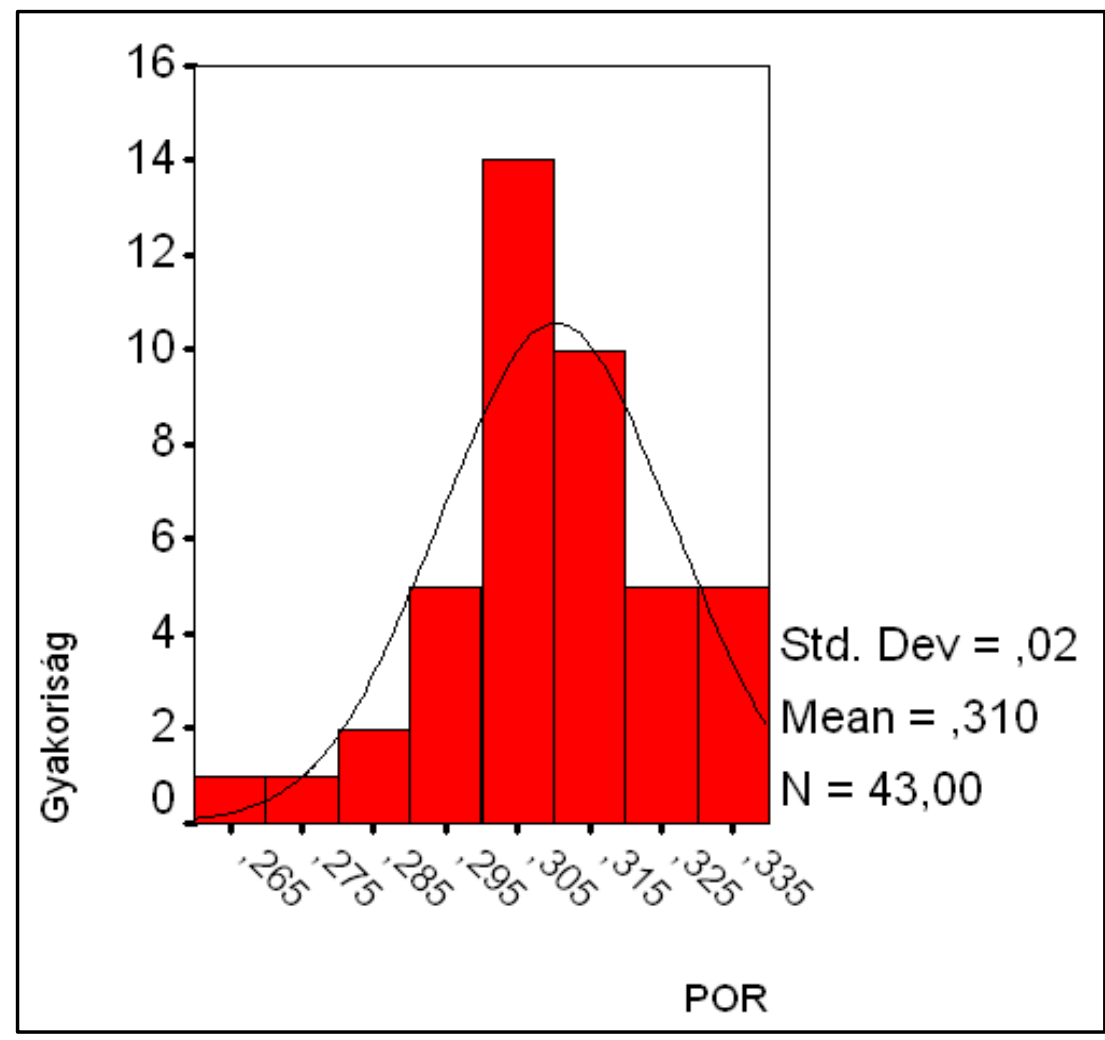

8-10. ábra A homokkövek porozitásértékeinek gyakorisági hisztogramja

\subsubsection{Homokkövek permeabilitása}

A permeabilitások esetében a vízszintes és függőleges permeabilitás eloszlása jelentősen eltér egymástól (8-11. ábra). A KLf esetében a fő módus az 500 mD értékek körül jelentkezik, míg a KLv értékei bimodális eloszlást mutatnak. Fő módusát az 1000 mD, mellékmódusát a $2000 \mathrm{mD}$ körüli értékek jelentik, mely kettősség ismét a homokkövek meder-mederáttörési lóba kettős genetikájának köszönhető. 

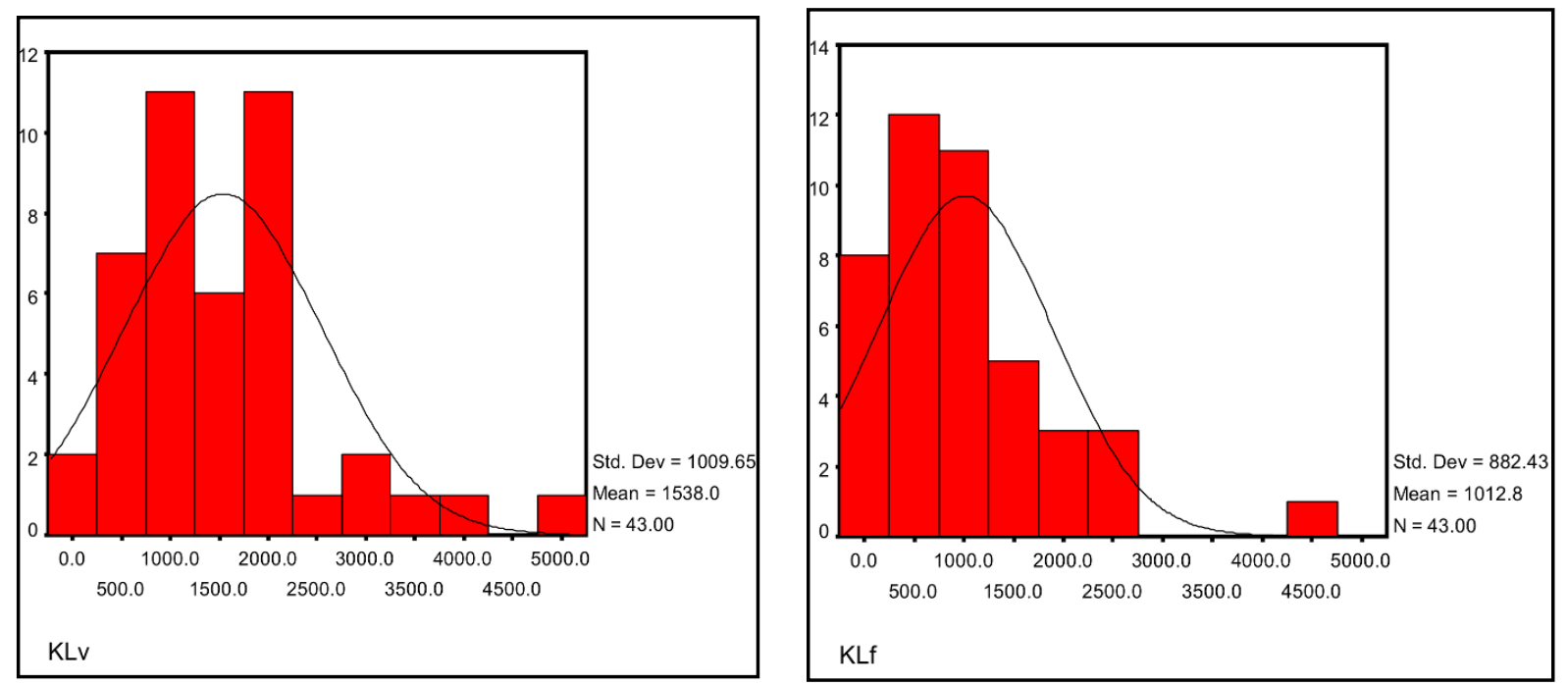

8-11. ábra A homokkövek permeabilitásainak gyakorisági hisztogramja

\subsection{A porozitás és permeabilitás jellemzői az egyes üledékes fáciesekben}

A porozitást és permeabilitást befolyásoló leülepedési és leülepedés utáni geológiai folyamatok kiemelt szereppel bírnak egy tároló termelési teljesítményének megértésében és előrejelzésében.

A homokkövek porozitása általában elsődleges, szemcseközi porozitás, melyet a diagenezis hatásai a későbbiek során módosíthatnak, így másodlagos porozitás alakulhat ki.

Mivel az eddigi vizsgálatok alapján azt mondhatjuk, hogy a Szőreg-1 telep vizsgált mintáinak porozitása elsődleges felhalmozódási eredetü porozitás, valószínüsíthető a kőzetfizikai tulajdonságok üledékes környezetek szerinti csoportosulása is.

Továbbiakban ennek vizsgálati eredményeit mutatom be. A porozitás és permeabilitás közötti korreláció vizsgálata során szembetűnő,hogy a két tulajdonság között pozitív kapcsolat van. Ettől a trendtől csak néhány kiugróan alacsony permeabilitású minta tér el (V-5 melléklet).

\subsubsection{Meder fácies homokkövei}

Ebbe a csoportba az elosztó medrek mintái tartoznak. A V-14. és V-6. mellékleten 1-es számmal jelölt extrém alacsony porozitású és permeabilitású agyagmárga mintát az adatsorból kiszürtem, így az elosztó medrek porozitás tartománya a fáciesek között a leghomogénebbnek tekinthető. Szórása 0,00892. A mederhomokkövek porozitás- tartománya 0,28 és 0, 32 közé esik (V-4. melléklet). 
Permeabilitásuk nem mutat extrém kiugró értékeket. A KLv kb. 320 és 2351 mD közötti tartományt ölel fel, a KLf megközelítőleg $56 \mathrm{mD}$ és $1886 \mathrm{mD}$ közé eső értékeket vesz fel (V-4. melléklet).

\subsubsection{Meder és természetes partgát komplex homokkövei}

Ebbe a csoportba azok a minták tartoznak, melyek a természetes partgát víz alatti részén, a meder partközeli részén, illetve egy rövid ideig állandósult mederáramlásoktól kevésbé háborgatott részén halmozódtak fel. Ennek megfelelően porozitásuk a fáciesek között a legnagyobb heterogenitást mutatja. Értéktartománya 0,18 és 0,31 közé esik (V-4. melléklet).

Permeabilitás értékeit az V-4. melléklet tartalmazza. Kiugró értékek nem jelennek meg közöttük (V-15. melléklet).

A porozitásuk és permeabilitásuk közötti kapcsolat vizsgálata során felállított scatterploton jól látható, hogy a minták egymástól elkülönülő csoportokban jelennek meg (V-7. melléklet). Az egyik csoport egy magasabb porozitás és permeabilitás értékkel jellemezhető, míg a másik csoport alacsonyabbakkal. Ez a kettősség természetesen a két üledékképződési környezet eltérő kőzetfizikai és szöveti tulajdonságokat eredményező jellegének köszönhető. Míg előbbi az inkább meder-jellegű felhalmozódások csoportját foglalja magába, az utóbbi a természetes partgát víz alatti részének alacsony porozitású és permeabilitású, finomszemü üledékes kőzeteit (V-8. melléklet). Az üledékes környezetek ilyen módon való elkülönítése csak azoknál az üledékeknél lehetséges, melyeknek porozitása elsődleges, szedimentációs eredetü, és diagenetikus hatások még nem, vagy csak kevéssé befolyásolják azt.

\subsubsection{Mederáttörési lóbák homokkövei}

Porozitásuk viszonylag nagy, 0,24 és 0,32 közötti értékekkel jellemezhető (V-4. melléklet). Kiugró értékek a permeabilitás adatok között jelennek meg, melyek a két tulajdonság kapcsolatát feltáró diagramon és a hozzájuk tartozó box ploton is elkülöníthetőek ( 1-es és 2-es számmal jelölt minták, V-9. és V-16. mellékletek).

\subsubsection{Progradáló mederáttörések}

Olyan minták tartoznak ide, melyek egy mederáttörési lóba progradációjának valamely üledéktestéből származnak, így tulajdonságaikban mederáttörésre, vagy a lóbán kifejlődött és progradáló keskeny elosztó meder progradációjára jellemző kőzetszöveti jelleg keveredhet bennük. 
$\mathrm{Az}$ egyes fácieseket összevetve a progradáló mederáttörések bírnak a legmagasabb porozitás értékekkel (0,28-0,34 lsd. V-4. melléklet), melyeknek szórása csekély (V-17. és V4. mellékletek), ugyanakkor permeabilitásuk szórása a legnagyobbnak számít mind a vízszintes, mind a függőleges permeabilitás tekintetében (V-4., V-10. és V-17. melléklet). Ennek magyarázata az üledékek felfelé durvuló ciklusos jellege, mely lehetővé teszi a nagy pórusok kialakulását. Ezzel együtt megjelenhet a pórustorkokat leszükítő finomabb frakció is, mely a permeabilitásban szélsőségeket eredményezhet.

\subsubsection{Mederáttörés és mederfelhagyás}

Ebbe a csoportba olyan minták tartoznak, melyek egy epizodikus mederáttörést követő gyors mederfelhagyás során képződhettek, de inkább a szakasz nyugalmi időszaka alatt felhalmozódott üledékeket mintázták meg. A vízszintes permeabilitás adatok között az extrém értéket egy a mederáttörésből származó homokkő minta képezi (V-11. és V-18. melléklet, 1es számmal jelölve). A statisztikai sokaság javára az egyetlen homokkő mintát kiszürve az aleurolitok és egy agyagmárga mintán végeztem el az analízist.

A porozitásuk az agyagmárgát illetve finom aleuritot jellemző 0,16-tól a finomhomokos durva aleurolit 0,27-es porozitás értékig terjed (V-4. melléklet). Permeabilitásaik szórása a vizsgált fáciesek között a legkisebb szórású, tehát permeabilitás szempontjából homogénnek mondható, ám -nem meglepően- nagyon alacsony permeabilitásúak (V-4. melléklet, V-18. melléklet).

A porozitás és permeabilitás kapcsolatában az egyes fáciesek elkülönülését az V-12. és az V-13. mellékletek szemléltetik.

\subsection{Az üledékes genetika megjelenése a szemcseméret-eloszlásokban}

A szemcseméret eloszlás és az üledékes fáciesek közötti kapcsolat vizsgálata során a magvizsgálatok adatait genetikai alapon 5 fáciesre és 1 átmeneti fáciesre osztottam, melyek a következők voltak: (1) természetes partgát és meder- együttesek (2) elosztó medrek (3) mederáttörési lóbák (4) progradáló mederáttörések (5) mocsár és mederfelhagyás üledékei (6) mederáttörés- és felhagyás üledékei, mint átmeneti fácies. A hozzájuk tartozó, átlagolt szemcseméreteloszlások kumulatív görbéit a 8-12. ábra mutatja. A görbék értelmezéséhez elengedhetetlen az üledékes genetika ismerete is.

A mocsár- mederfelhagyás fácieséhez tartozó minták szemcseméret eloszlása mutatja a legnagyob heterogenitást. A vizsgált szemcsék több mint 50\%-át a 20 mikronnál kisebb (finom aleurolit frakció és annál is apróbb szemcsék) alkotják. A 100 mikronnál nagyobb szemcsék a vizsgálati anyagban csak elenyésző mértékben voltak jelen (8-12. ábra). Ez a 
mocsaras területekre időszakosan betörő, a csendesvízi szuszpenzióból történő kiülepedést megzavaró áramlásokból származó finomhomok és finomhomokos aleurolit következménye.

A mederáttörési lóbák esetében az üledékek részben az elosztó medrek üledékét, részben pedig az erodált természetes partgát üledékét is tartalmazzák. Minthogy e képződmények kialakulását döntően az áramlási energia, az üledék utánpótlás növekedése, és a kisebb- nagyobb áradási események határozzák meg, a kumulált szemcseméret eloszlási görbén a finom és közepes szemcseméretü üledékek mellett ez a nagyon durva szemcséjü üledékek megjelenésében és a rossz osztályozottságban nyilvánul meg (8-12. ábra).

A fent leírt energiaviszonyok állandósulása, illetve a folyamatok ismétlődése következtében a mederáttörési lóbák progradáló jelleget vehetnek fel. Következményképpen üledékük az elosztó medrekénél valamivel jobban osztályozott. A szemcséknek több mint 50\%-a a 100-300 mikronos tartományba esik, mely egyszerre tartalmazza a korábbi mederáttörési lóbák átdolgozott, áthalmozott anyagát, a mederformálódás során lerakódott üledékeknek egy részét, illetve amennyiben volt ilyen, egy roncsolódott természetes partgát víz alatti üledékeit is. A nagyon nagy szállítási energia miatt itt jelenik meg a legdurvább szemcseméret. Mindennek ellenére üledékei mégis a legmeredekebb görbékkel, a legjobb osztályozottsággal jellemezhetőek, mivel a 10 mikronnál kisebb szemcsék megjelenése nem számottevő, mintegy $10 \%$ (8-12. ábra).

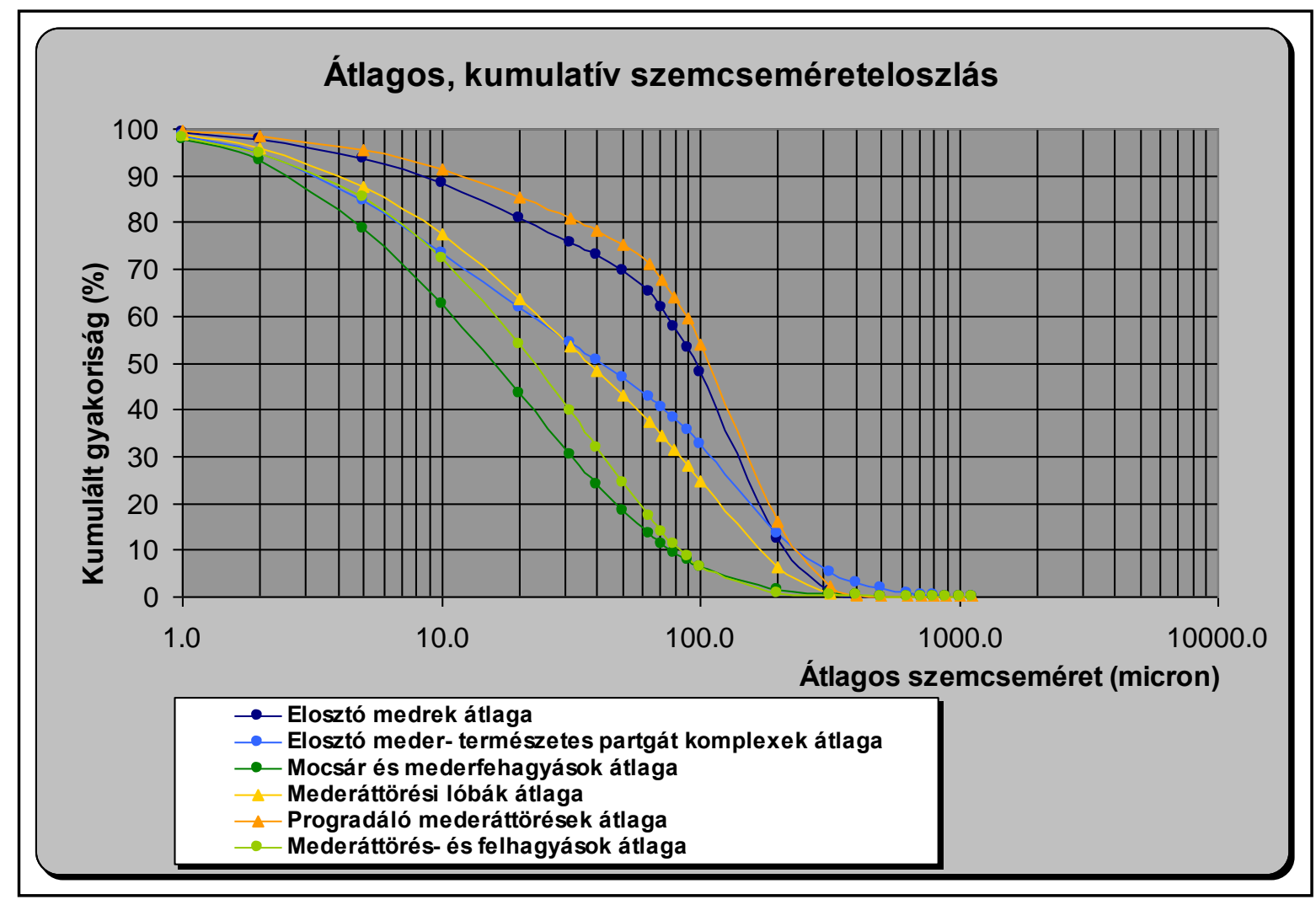

8-12. ábra Az egyes fáciesekhez tartozó átlagolt, kumulatív szemcseméret-eloszlások görbéi 


\subsection{Higanyos mérések}

A higanyos mérések adatsorát az alábbi pórusméret osztályok határozzák meg:

- 37.5 mikronnál nagyobb pórustorkok

- 25-37.5 mikron közötti pórustorkok

- 15-25 mikron közötti pórustorkok

- 10-15 mikron közötti pórustorkok

- 7.5-10 mikron közötti pórustorkok

- 5-7.5 mikron közötti pórustorkok

- 2.5-5 mikron közötti pórustorkok

- 1-2.5 mikron közötti pórustorkok

- 0.25-1 mikron közötti pórustorkok

- 0.1-0.25 mikron közötti pórustorkok

- 0.02-0.1 mikron közötti pórustorkok

- 0.00375-0.02 mikron közötti pórustorkok

A feldolgozás során a fenti 12 méretosztály gyakorisági tulajdonságainak elemzésére került sor. A vizsgálatokba bevontuk az átlagos pórustorok méretet is. Az átlagos pórustorok méretek három eloszlás keverékéből állnak, mely három módusú hisztogramban mutatkozik meg (8-13. ábra). A fömódus az 1.7- 3.3 mikron, az 1. mellékmódus a 10.0- 11.7 mikron, a 2. mellékmódus pedig a 15- 16.7 mikron közötti osztályokat jelöli.

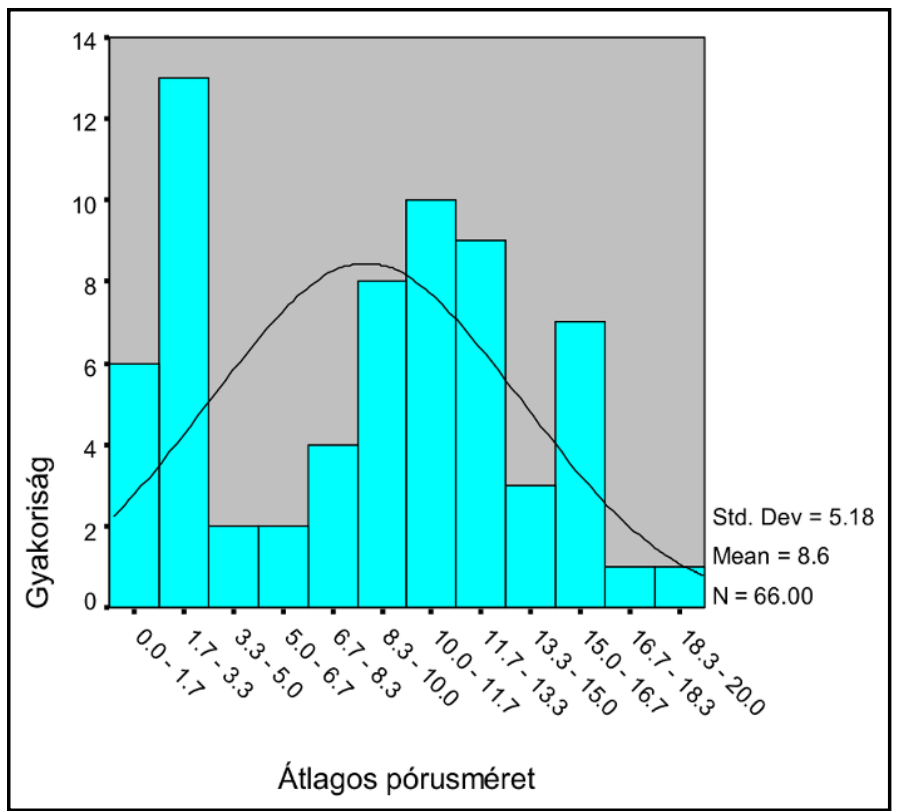

8-13. ábra A vizsgált minták átlagos pórusméret- eloszlása 


\subsubsection{Az egyes pórusméret osztályok gyakoriságai}

Az egyes pórusméret osztályok gyakoriságait vizsgálva megállapítható, hogy eloszlásuk többnyire nem unimodális, hanem több eloszlás keverékeként megjelenő polimodális eloszlás (V-19-V-30. mellékletek). Leginkább homogén eloszlással a 37,5 mikronnál nagyobb pórusok (V-19. melléklet), az 5- 7.5 mikronos tartomány (V-24. melléklet) és a 0.25-1 mikron közé eső pórusok (V-27. melléklet) jellemezhetőek Ez azzal magyarázható, hogy a pórustér kialakulására nem csak a diagenetikus viszonyok, de a későbbi szedimentációs hatások is rányomták bélyegüket. A keverékeloszlások esetében a pórustér végső tulajdonságát dominánsan meghatározó folyamat jellege a SEM felvételek segítségével ítélhető meg.

A pórusméret osztályok gyakorisági eloszlása a 7,5-15 mikron közé eső intervallumon belül nem mutat sem kiugró, sem extrém értékeket (8-14. ábra), ami arra utal, hogy ez a pórusméret kategória a diagenezis során illetve után nem szenvedett olyan változásokat, melyek a korábbi pórusrendszert érintették.

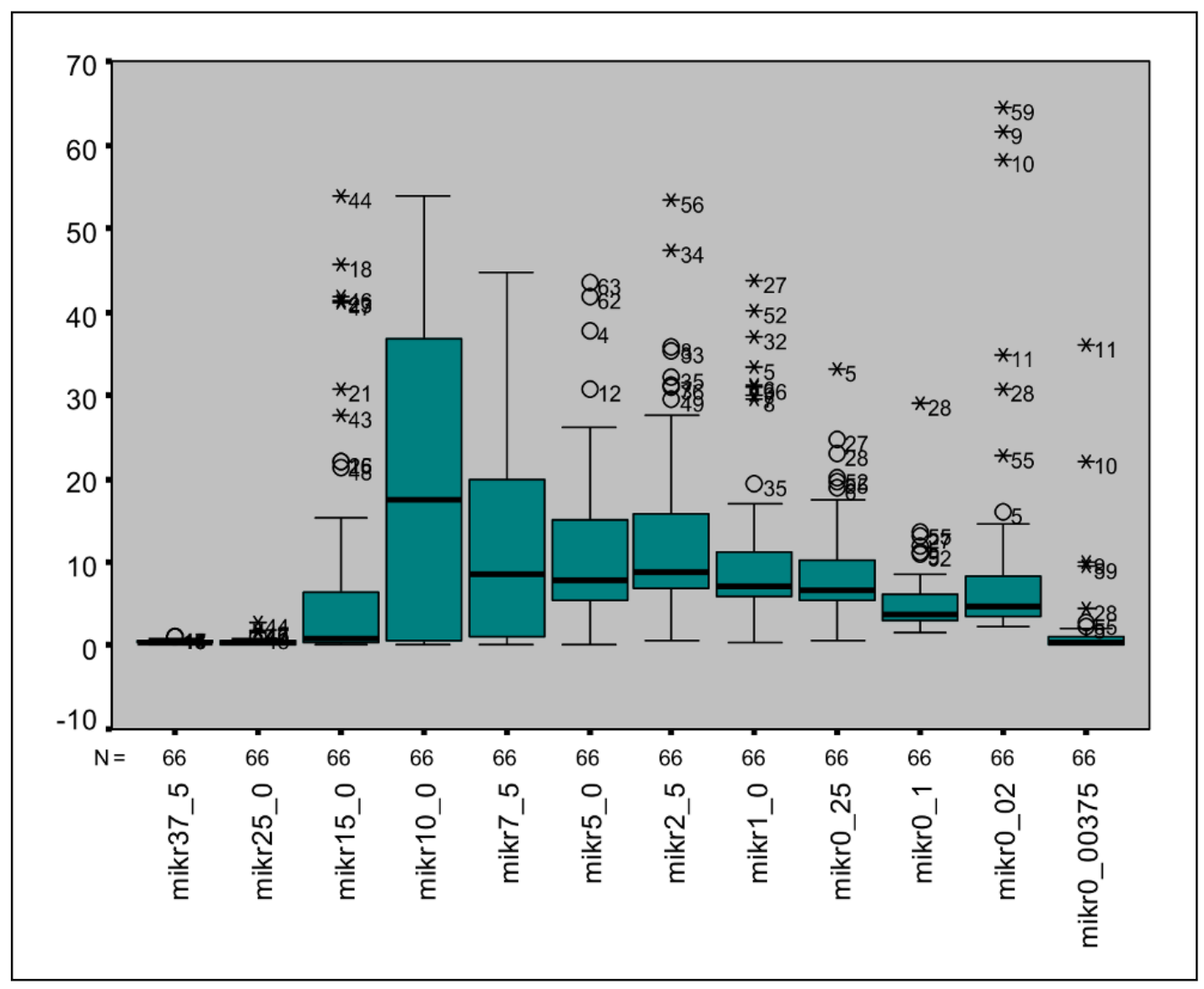

8-14. ábra A pórusméret-osztályok box-plotjai az extrém és kiugró értékekkel 


\subsubsection{A porozitás és permeabilitások kapcsolata a szemcseméret-eloszlással, pórusszerkezettel és a karbonát tartalommal}

A kőzetszövetnek, a - legtöbbször diagenetikus eredetü - karbonát tartalomnak és a pórusszerkezetnek porozitással és permeabilitásokkal alkotott kapcsolatát faktoranalízis segítségével vizsgálom. Ennek alapjául az szolgál, hogy a módszer a vizsgált tulajdonságok közötti kapcsolatrendszert leíró korrelációk alapján a meghatározó tényezőket olyan faktorokkal társítja, melyek mögött az adott tulajdonságra vonatkozó, azt meghatározó folyamat áll. Az analízis során kapott faktorsúlyok a változóknak az adott faktorral való összefüggését, illetve korrelációs együtthatókhoz hasonlóan a függés mértékét és irányát mutatják meg. Ennek megfelelően a vizsgálat során az egyes változókat meghatározó faktorok eltérő faktorsúllyal szerepelnek. A cél a változókat döntően meghatározó faktorok számának csökkentése olyan okváltozók - azaz szakmai háttérváltozók - kiszürésével, melyek a változók varianciájáért nagymértékben felelősek. Az analízisbe bevont tulajdonságok az alábbiak voltak (8-2. táblázat):

\begin{tabular}{|c|c|c|c|}
\hline Tulajdonság & Jele & Tulajdonság & Jele \\
\hline Közepes szemcseméret & Zscore: átlag & $\begin{array}{l}37.5 \text { m-nál nagyobb pórusok } \\
\text { gyakorisága }\end{array}$ & Zscore: 37.50 \\
\hline Osztályozottság & Zscore: szórás & $\begin{array}{l}\text { 25-37.5 m közötti pórusok } \\
\text { gyakorisága }\end{array}$ & Zscore: 25.00 \\
\hline Agyag frakció & Zscore: agyag & $\begin{array}{l}15-25.0 \mathrm{~m} \text { közötti pórusok } \\
\text { gyakorisága }\end{array}$ & Zscore: 15.00 \\
\hline Finom aleurit frakció & Zscore: fin_al & $\begin{array}{l}\text { 10-15 m közötti pórusok } \\
\text { gyakorisága }\end{array}$ & Zscore: 10.00 \\
\hline Durva aleurit frakció & Zscore: du_al & $\begin{array}{l}\text { 7.5- } 10 \mathrm{~m} \text { közötti pórusok } \\
\text { gyakorisága }\end{array}$ & Zscore: 7.50 \\
\hline Finomhomok frakció & Zscore: f_hom & $\begin{array}{l}\text { 5- } 7.5 \text { m közötti pórusok } \\
\text { gyakorisága }\end{array}$ & Zscore: 5.00 \\
\hline $\begin{array}{l}\text { Apróhomok és középszemü } \\
\text { homok frakció }\end{array}$ & Zscore: a_k_hom & $\begin{array}{l}2.5-5 \mathrm{~m} \text { közötti pórusok } \\
\text { gyakorisága }\end{array}$ & Zscore: 2.50 \\
\hline Porozitás & Zscore: Poroz & $\begin{array}{l}\text { 1- } 2.5 \text { m közötti pórusok } \\
\text { gyakorisága }\end{array}$ & Zscore: 1.00 \\
\hline $\begin{array}{l}\text { Vízszintes irányú ekvivalens } \\
\text { (korrigált)permeabilitás }\end{array}$ & Zscore: KLv & $\begin{array}{l}0.25-1 \text { m közötti pórusok } \\
\text { gyakorisága }\end{array}$ & Zscore: 0.25 \\
\hline $\begin{array}{l}\text { Függőleges irányú ekvivalens } \\
\text { (korrigált) permeabilitás }\end{array}$ & Zscore: KLf & $\begin{array}{l}0.1-0.25 \mathrm{~m} \text { közötti pórusok } \\
\text { gyakorisága }\end{array}$ & Zscore: 0.10 \\
\hline $\begin{array}{l}\text { Vizszintes irányú mért } \\
\text { permeabilitás }\end{array}$ & Zscore: Kv & $\begin{array}{l}0.02-0.1 \mathrm{~m} \text { közötti pórusok } \\
\text { gyakorisága }\end{array}$ & Zscore: 0.02 \\
\hline \multirow[t]{2}{*}{$\begin{array}{l}\text { Függőleges irányú mért } \\
\text { permeabilitás }\end{array}$} & Zscore: Kf & $\begin{array}{l}0.00375-0.02 \mathrm{~m} \text { közötti pórusok } \\
\text { gyakorisága }\end{array}$ & Zscore: 0.00375 \\
\hline & & Összes karbonát tartalom & Zscore: Össz karb \\
\hline
\end{tabular}

8-2. táblázat A faktoranalizisbe bevont tulajdonságok 
A faktoranalízis algoritmusa a főkomponens módszer volt. A 8-3. táblázat mutatja az összvariancia értékeket a sajátértékekkel és a fơkomponensekkel. Az első oszlop tartalmazza a komponenseket. Ebben az esetben a kezdeti sajátértékek összvarianciáját 25 komponens magyarázza. Az első komponens a vizsgált változók varianciáját 41.033\%-ban határozza meg. A 25 komponensből az első 7 komponens a változók varianciájának mintegy 90\%-át magyarázza. Az első főkomponens a vizsgált változók 41\%-át, míg az első hét komponens együttesen a megfigyelt változókat körülbelül 90\%- ban magyarázza (8-3. táblázat).

A vizsgált tulajdonságok együttes változékonyságának minél pontosabb visszavezetése érdekében az 5 db 1-nél nagyobb sajátértékkel rendelkező faktoron kívül a vizsgált szakmai háttérváltozók számát további két faktorral bővítettük. Ez az utolsó két faktor valójában az együttes változékonyságnak csak csekély százalékát teszi ki, mégis fontos genetikai információk hordozója lehet.

\begin{tabular}{|c|c|c|c|c|c|c|}
\hline \multicolumn{7}{|c|}{ Total Variance Explained } \\
\hline \multirow[b]{2}{*}{ Comnonent } & \multicolumn{3}{|c|}{ Initial Figenvalues } & \multicolumn{3}{|c|}{ Extraction Sums of Squared $/$ oadings } \\
\hline & Total & $\begin{array}{c}\% \text { of } \\
\text { Variance }\end{array}$ & Cumulative \% & Total & $\begin{array}{c}\% \text { of } \\
\text { Variance }\end{array}$ & Cumulative $\%$ \\
\hline 1 & 10.258 & 41.033 & 41.033 & 10.258 & 41.033 & 41.033 \\
\hline 2 & 3.471 & 13.882 & 54.916 & 3.471 & 13.882 & 54.916 \\
\hline 3 & 3.177 & 12.708 & 67.624 & 3.177 & 12.708 & 67.624 \\
\hline 4 & 2.246 & 8.985 & 76.609 & 2.246 & 8.985 & 76.609 \\
\hline 5 & 1.314 & 5.257 & 81.866 & 1.314 & 5.257 & 81.866 \\
\hline 6 & .975 & 3.899 & 85.766 & .975 & 3.899 & 85.766 \\
\hline 7 & .863 & 3.453 & 89.219 & .863 & 3.453 & 89.219 \\
\hline 8 & .814 & 3.256 & 92.475 & & & \\
\hline 9 & .474 & 1.896 & 94.370 & & & \\
\hline 10 & .387 & 1.546 & 95.917 & & & \\
\hline 11 & .338 & 1.354 & 97.270 & & & \\
\hline 12 & .191 & .763 & 98.033 & & & \\
\hline 13 & .155 & .620 & 98.653 & & & \\
\hline 14 & .115 & .459 & 99.112 & & & \\
\hline 15 & $9.41 \mathrm{E}-02$ & .377 & 99.489 & & & \\
\hline 16 & $5.95 \mathrm{E}-02$ & .238 & 99.726 & & & \\
\hline 17 & 2.93E-02 & .117 & 99.844 & & & \\
\hline 18 & $2.07 \mathrm{E}-02$ & $8.270 \mathrm{E}-02$ & 99.926 & & & \\
\hline 19 & $1.02 \mathrm{E}-02$ & $4.070 \mathrm{E}-02$ & 99.967 & & & \\
\hline 20 & $4.55 \mathrm{E}-03$ & $1.818 \mathrm{E}-02$ & 99.985 & & & \\
\hline 21 & $2.16 \mathrm{E}-03$ & $8.630 \mathrm{E}-03$ & 99.994 & & & \\
\hline 22 & $9.34 \mathrm{E}-04$ & $3.736 \mathrm{E}-03$ & 99.998 & & & \\
\hline 23 & $5.85 \mathrm{E}-04$ & $2.338 \mathrm{E}-03$ & 100.000 & & & \\
\hline 24 & $1.05 \mathrm{E}-05$ & $4.212 \mathrm{E}-05$ & 100.000 & & & \\
\hline 25 & $6.47 \mathrm{E}-06$ & $2.589 \mathrm{E}-05$ & 100.000 & & & \\
\hline
\end{tabular}

8-3. táblázat A faktoranalizis összvariancia táblázata a sajátértékekkel és a fökomponensekkel 
A fökomponens- súly mátrixának értékei -1 és +1 közötti értékeket vehetnek fel (8-4. táblázat). Az egyes fökomponens- súlyok tulajdonképpen a változók és a fökomponensváltozók közötti korrelációs együtthatóként értelmezhetőek. A táblázatban látható a rotáció előtti faktorsúly mátrix, melyben csak a 0.3-nál nagyobb faktorsúllyal rendelkező értékek szerepelnek (8-4. táblázat).

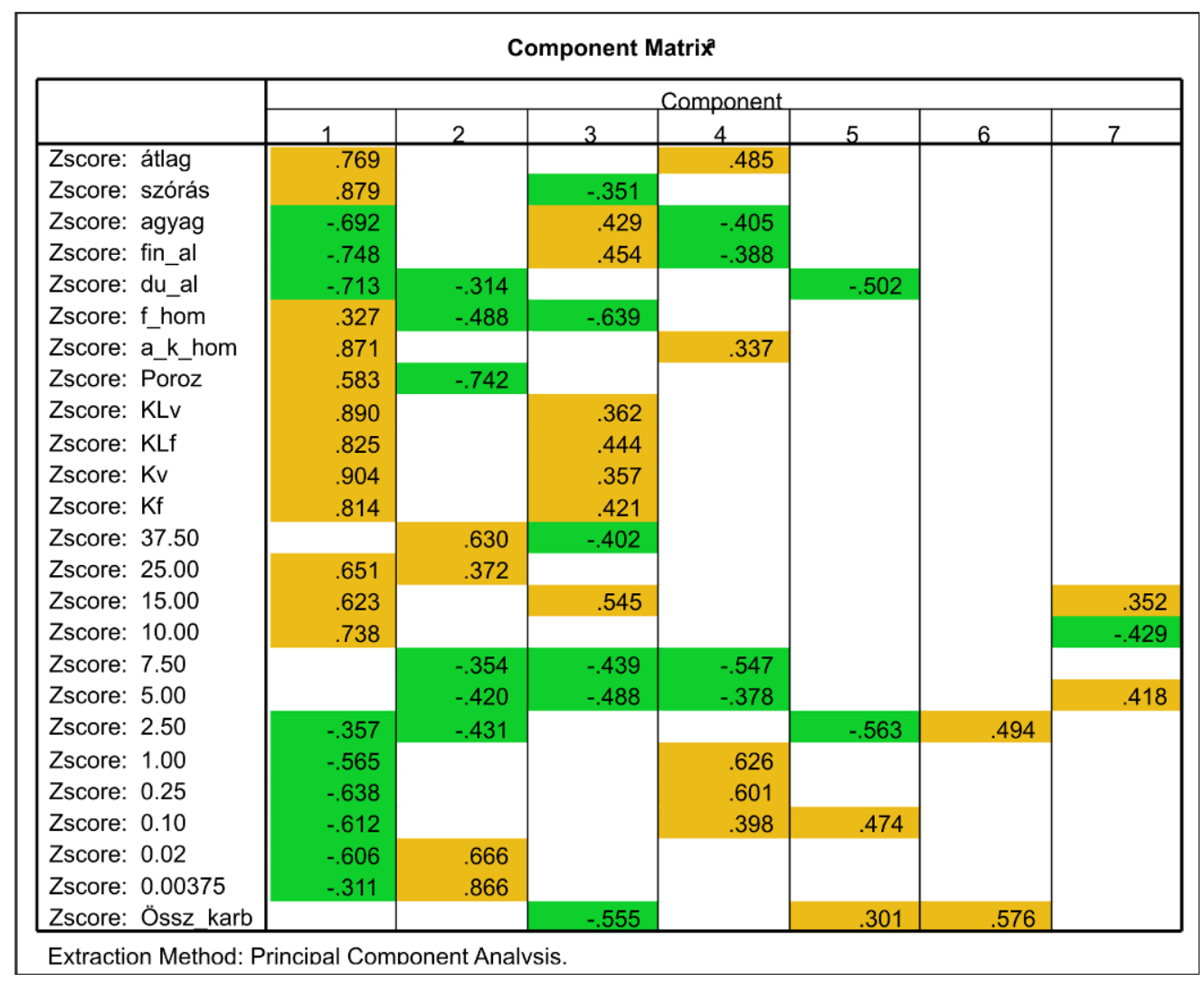

8-4. táblázat A rotáció előtti faktorsúly- mátrix

A mátrixban több esetben is megfigyelhető a fökomponens- súlyok csoportosulása. Ebből következik, hogy ezek a változók egymással csoportosan korrelálnak, vagyis olyan közös háttérváltozóval magyarázhatók, melyek a változókat együttesen határozzák meg, a főkomponens-súly értékeknek megfelelö irányban.

Az első faktor hatására a finom szemcsefrakció (agyag, finom aleurit) gyakorisága csökken, a homok frakció gyakorisága nő. Ezzel párhuzamosan a kőzetszövet durvulása és az osztályozottság javulása figyelhető meg. A szöveti durvulás a kisméretü pórusok gyakoriságának csökkenésével és a 10 mikronnál nagyobb pórusok gyakoriságának növekedésével jár. Mindez a porozitás és a permeabilitások javulásához vezet. Ezek alapján az első faktort az osztályozottság javulását és az átlagos szemcseméret növekedését elősegítő hordalékszállítással illetve a szuszpenzióból történő osztályozó kiülepedéssel azonosíthatjuk. 
Ilyen folyamatot idézhet elő a fokozatosan erősödő, vagy csökkenő energiájú áramlásokból történő kiülepedés.

A második faktor szerint nő a nagyon kicsiny (0,02-0,00375 mikron) pórusok gyakorisága, mely a porozitás romlását eredményezi. Ezzel együtt a közepes pórusok rovására - a durva aleurit és a finomhomok frakció kismértékű csökkenésével párhuzamosan - nő a nagy pórusok gyakorisága is (25 mikronnál nagyobb pórusok), de ezek az effektív porozitás kiépítésében nem vesznek részt, valószínűleg éppen a felszaporodó szük pórustorkok miatt. Az osztályozottságot, az átlagos szemcseméretet, a karbonát-tartalmat és a permeabilitásokat nem érinti a faktor hatása. A második faktor vagy az üledékek áramló közegből történő hirtelen kiülepedésével azonosítható, mely során az osztályozódás hiánya miatt az eltérő méretü szemcsék között az extrém nagy pórusok mellett a nagyon kicsi pórusok elöfordulási gyakorisága nő - azonban a pórusok egymással sok esetben nem kommunikálnak, így az effektív porozitást rontják -, vagy egy olyan átmeneti szöveti rendszert jelöl, mely rövid ideig tartó, magasabb energiaszintü folyamatok hatására alakul ki. Lokális áthalmozódások, rövid ideig tartó folyamatok hatása, mely nem eredményez határozott szöveti, ill. pórusrendszert.

A harmadik faktor hatására az üledékekben nő a finom frakció (agyag, finom aleurit), és csökken a finomhomok gyakorisága. Ennek hatására nő a 15,0- 25,0 mikron közötti pórusok gyakorisága és csökken az 5 és 10 mikron közé eső pórusok gyakorisága. Az extrém nagy pórusok előfordulása és a karbonáttartalom is csökken. Az üledék osztályozottsága kis mértékben romlik. Ezek eredményeképpen a permeabilitások javulása figyelhető meg. A finom frakció növekedése és a homokos üledékek előfordulása nem magyarázza a javuló permeabilitást, így ez csak akkor magyarázható, ha az üledékben megjelenő finom frakció nem póruskitöltésként jelenik meg, hanem önálló formában alkot szöveti jellegzetességet. Ez a minták között sok esetben aleurolit intraklasztok formájában meg is jelenik, mely a korábbi, konszolidálatlan aljzat áramlás általi eróziójának terméke, és a szemcseösszetételi vizsgálatok során önálló frakcióként jelenik meg. Ezek ismeretében a harmadik faktor az eróziós folyamatok által kialakított szövet pórusrendszerének heterogenitását fejezi ki. Ilyen intraklasztos homokköveket találhatunk a mederáttörési lóbák, progradáló mederáttörések és progradáló elosztómedrek eróziós folyamatok által felhalmozott üledékei között.

A negyedik faktor hatására a vizsgált mintákban nő az apró-és finomhomok frakció előfordulása, ami a szállítási energia kismértékü erősödésének köszönhetően az átlagos szemcseméret növekedésében is megnyilvánul. Ezzel együtt csökken az agyag és finom aleurit frakció gyakorisága, és csökken a 7,5- 5,0 mikronos pórusméretek előfordulása, valamint nő az 1 mikronnál kisebb pórusok előfordulásának gyakorisága. Ezek alapján megállapítható, hogy a negyedik faktorhoz olyan folyamat társítható, ami a szállítási energia 
kismértékü növekedésével jár, mely növeli az átlagos szemcseméretet, de az osztályozottságot nem befolyásolja, valamint a közepes pórusméretek beszükülését, és a kicsiny pórusok felszaporodását okozza.

Az ötödik és hatodik faktor a vizsgált minták összvarianciájának relatíve kis százalékát magyarázza, viszont ez a két faktor az, amelyben megnyilvánul a karbonát ásványok hatása. A karbonát ásványok jelenléte a 2,5-és 5 mikron közötti pórusméret tartományt szükíti le, valamint a 0,1- 0,25 mikron közötti pórusméret tartomány gyakoriságát növeli.

A hetedik faktor csak tájékoztató jelleggel szerepel az analízisben, mivel a vizsgált tulajdonságoknak igen kis százalékát magyarázza. A hetedik faktor valószínüsíthetően valamilyen diagenetikus hatás, mely az 5 mikronos pórusméretek előfordulását a 10 mikronos pórusméretek rovására növeli. Ilyen hatású lehet többek között (itt nem karbonátos) ásványkicserélődés, vagy újrakristályosodási folyamatok. Pontosabb megnevezése a SEM vizsgálatok eredményei segítségével tehető meg.

Azt, hogy a faktorok az eredeti változók varianciáját mennyire jól magyarázzák, a kommunalitás- értékek mutatják meg. Mivel az analízis során kapott kommunalitás értékek minden esetben magasak, a kiválasztott komponensek a változókat jól reprezentálják (8-5. táblázat.

\begin{tabular}{|l|r|r|}
\hline & \multicolumn{3}{|c|}{} \\
\hline & Initial & Extraction \\
\hline Zscore: átlag & 1.000 & .933 \\
Zscore: szórás & 1.000 & .989 \\
Zscore: agyag & 1.000 & .945 \\
Zscore: fin_al & 1.000 & .978 \\
Zscore: du_al & 1.000 & .916 \\
Zscore: f_hom & 1.000 & .882 \\
Zscore: a_k_hom & 1.000 & .980 \\
Zscore: Poroz & 1.000 & .946 \\
Zscore: KLv & 1.000 & .942 \\
Zscore: KLf & 1.000 & .892 \\
Zscore: Kv & 1.000 & .956 \\
Zscore: Kf & 1.000 & .867 \\
Zscore: 37.50 & 1.000 & .759 \\
Zscore: 25.00 & 1.000 & .684 \\
Zscore: 15.00 & 1.000 & .908 \\
Zscore: 10.00 & 1.000 & .866 \\
Zscore: 7.50 & 1.000 & .809 \\
Zscore: 5.00 & 1.000 & .847 \\
Zscore: 2.50 & 1.000 & .890 \\
Zscore: 1.00 & 1.000 & .869 \\
Zscore: 0.25 & 1.000 & .928 \\
Zscore: 0.10 & 1.000 & .848 \\
Zscore: 0.02 & 1.000 & .866 \\
Zscore: 0.00375 & 1.000 & .933 \\
Zscore: Össz_karb & 1.000 & .872 \\
\hline
\end{tabular}

8-5. táblázat A vizsgált tulajdonságok kommunalitás értékei 


\subsubsection{A permeabilitások és a pórusméret- tartományok kapcsolatai az egyes kőzettípusokon belül a higanyos mérések eredményei alapján}

A pórusméreteloszlás kőzettípusonkénti vizsgálatához $44 \mathrm{db}$ homokkő és $18 \mathrm{db}$ aleurolit minta mérési eredményeit használtam fel.

\subsubsection{Homokkövek}

A homokkövek pórusméret eloszlásának jellegét a 8-15. ábra mutatja. A hisztogram alapján megállapítható, hogy az átlagos pórusméret kifejlődését homokkövek esetében két populáció keveréke adja. Az első populáció a 9,7- 11 mikron közötti átlagos pórusméret osztály. A másodikat a 12,28- 13,57 mikronos átlag közeli pórusméretek szolgáltatják. A két populáció közötti értékek csak kis gyakorisággal jelennek meg. Ilyen pórusméret eloszlást eredményezhet két eltérő szöveti fejlődéstörténet. A nagyobb pórusméret osztályok a vizsgált homokkövek meder- eredetét, míg a kisebbek a mederáttörési lóba eredetét tükrözik, mivel utóbbi esetben az osztályozódás hiánya a pórusteret beszükíti.

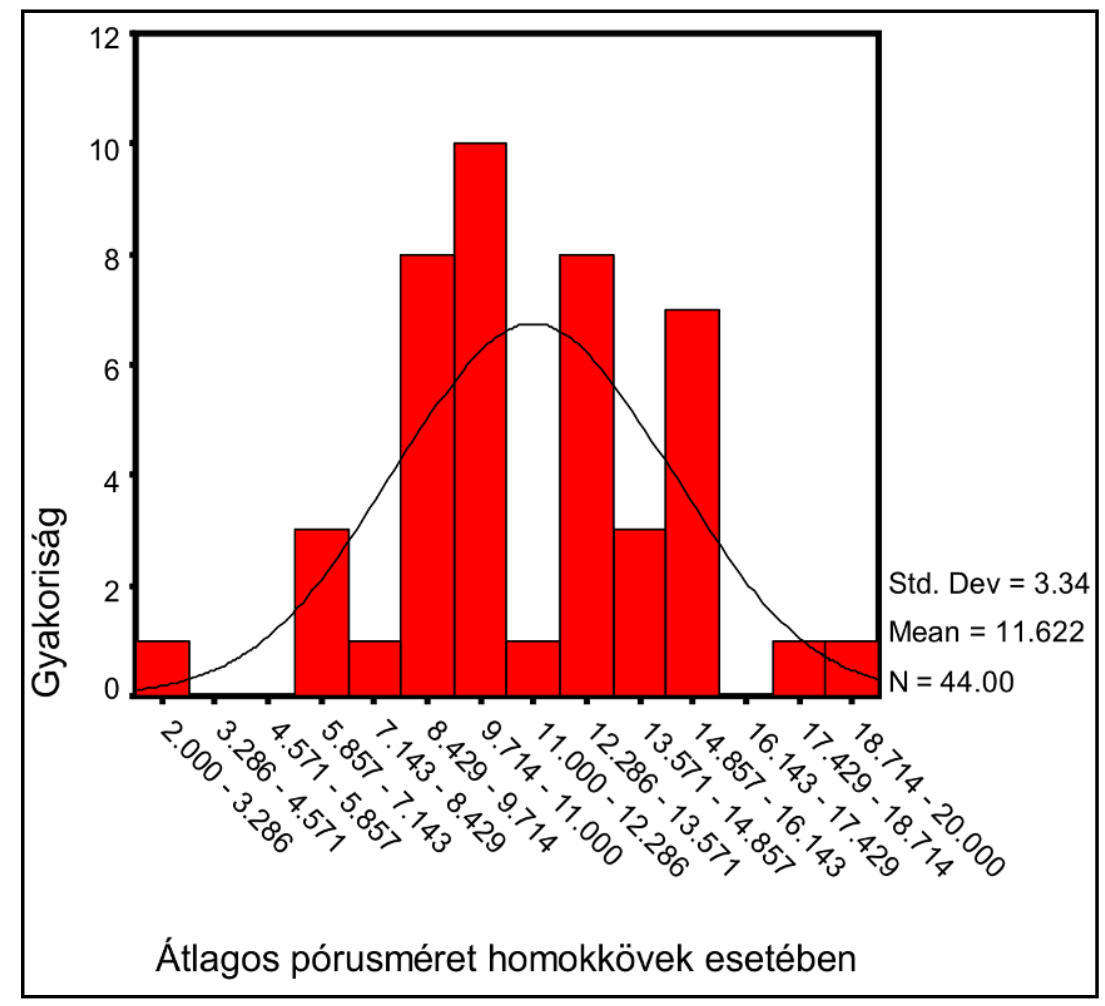

8-15. ábra Az átlagos pórusméret-eloszlás a homokkövek esetében

A homokkövek átlagos pórustorok átmérője 11,62 mikron, ami megfelel egy durva aleurolit szemcse hozzávetőleges méretének (8-15. ábra).

Homokkövek esetében a legnagyobb szórásúak a 7,5 és 25 mikron közé eső pórusméret osztályok. A leghomogénebb pórusméret osztály a nagyon kicsiny $(0,00375$ és az 1 mikron közötti) pórusok osztálya, valamint a másik véglet, a túlméretes pórusok (25 és 37 mikron feletti) osztálya. 
Az átlagos pórusméretek szórása a homokkövekben nagyobb, mint az aleurolitokban (8-6. táblázat). Ez azzal magyarázható, hogy durvább szemcséjü szövet pórusaiban a diagenetikus ásványkiválások nagyobb mértékben tudnak érvényesülni, mint egy szükösebb pórustérben.

\begin{tabular}{|c|c|c|c|c|c|c|c|c|}
\hline & \multirow{2}{*}{ Mean } & \multicolumn{2}{|c|}{$\begin{array}{l}95 \% \text { Confidence } \\
\text { Interval for Mean }\end{array}$} & \multirow{2}{*}{$\begin{array}{c}\mathbf{5 \%} \\
\text { Trimmed } \\
\text { Mean }\end{array}$} & \multirow{2}{*}{ Median } & \multirow{2}{*}{ Std.dev. } & \multirow{2}{*}{ Min. } & \multirow{2}{*}{ Max. } \\
\hline & & $\begin{array}{l}\text { Lower } \\
\text { Bound }\end{array}$ & $\begin{array}{l}\text { Upper } \\
\text { Bound }\end{array}$ & & & & & \\
\hline Átlag & 11.622 & 10.607 & 12.638 & 11.642 & 10.739 & 3.341 & 2.761 & 19.025 \\
\hline MIKR_37.5 & 0.478 & 0.404 & 0.552 & 0.457 & 0.394 & 0.243 & 0.200 & 1.168 \\
\hline MIKR_25.0 & 0.555 & 0.393 & 0.717 & 0.482 & 0.344 & 0.534 & 0.153 & 2.754 \\
\hline MIKR_15.0 & 10.317 & 5.820 & 14.815 & 8.727 & 2.710 & 14.792 & 0.253 & 53.833 \\
\hline MIKR_10.0 & 28.101 & 23.153 & 33.048 & 28.289 & 28.036 & 16.274 & 0.420 & 53.844 \\
\hline MIKR_7.5 & 16.886 & 13.472 & 20.300 & 16.153 & 12.786 & 11.230 & 2.437 & 44.783 \\
\hline MIKR_5.0 & 12.664 & 9.905 & 15.422 & 11.494 & 9.604 & 9.073 & 4.513 & 43.557 \\
\hline MIKR_2.5 & 9.558 & 8.307 & 10.810 & 9.053 & 8.543 & 4.115 & 5.296 & 27.471 \\
\hline MIKR_1.0 & 6.928 & 6.303 & 7.553 & 6.680 & 6.368 & 2.056 & 4.533 & 14.874 \\
\hline MIKR_0.25 & 6.430 & 5.856 & 7.003 & 6.238 & 6.064 & 1.886 & 4.249 & 12.248 \\
\hline MIKR_0.1 & 3.663 & 3.336 & 3.991 & 3.603 & 3.478 & 1.077 & 2.153 & 6.341 \\
\hline MIKR_0.02 & 4.078 & 3.687 & 4.468 & 3.992 & 3.787 & 1.285 & 2.226 & 7.647 \\
\hline MIKR_0.001 & 0.293 & 0.229 & 0.357 & 0.276 & 0.231 & 0.211 & 0.005 & 0.970 \\
\hline
\end{tabular}

8-6. táblázat A pórusméret osztályok statisztikai jellemzöi a homokkövekben

\subsubsection{Aleurolitok}

Az aleurolitokra jellemző átlagos pórusméret-eloszlást a 8-16. ábra szemlélteti.

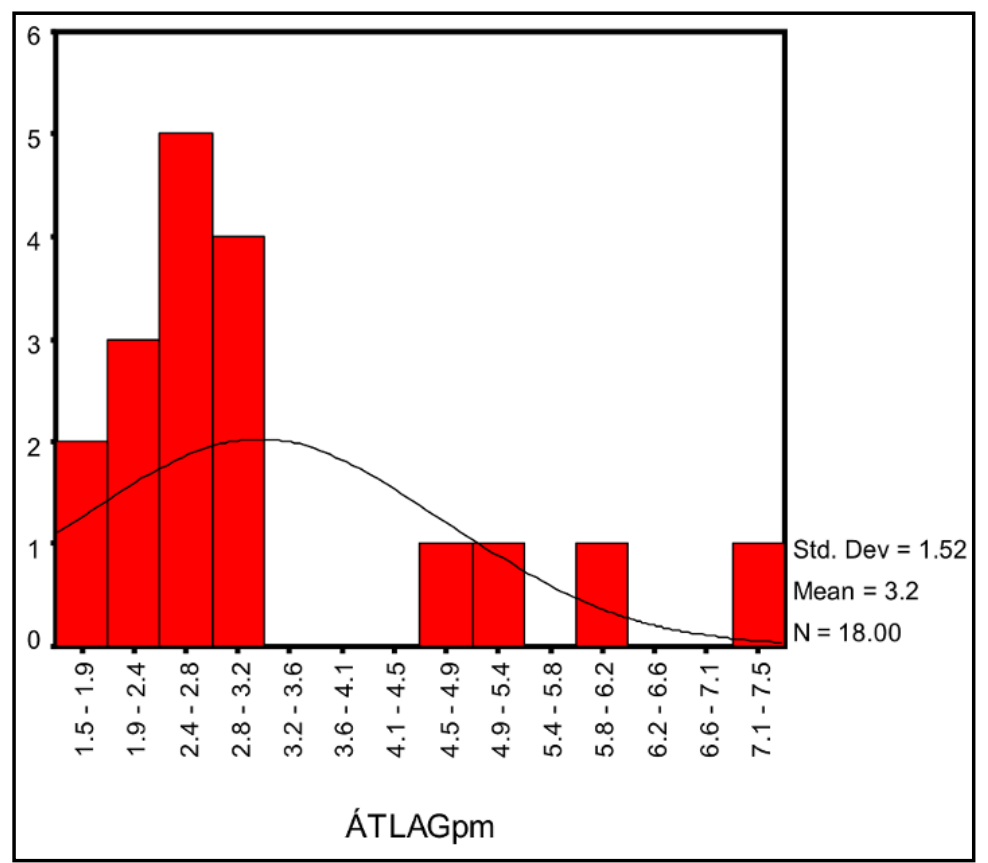

8-16. ábra Átlagos pórusméret eloszlás az aleurolitok esetében

Az eloszlás fő módusát a 2,4- 2,8 mikronos átlagos pórusmérettel jellemző osztály adja. A vizsgált minták átlagos pórustorok átmérője 3,17 mikron (8-7. táblázat). A leghomogénebb pórusméret osztályok a 0,001 és a 15 mikronnál nagyobb pórusméretek osztályok. 
Legnagyobb szórással az 1 és 7,5 mikron közé eső átlagos pórusméret osztályok rendelkeznek (8-7. táblázat).

\begin{tabular}{|c|c|c|c|c|c|c|c|c|}
\hline & \multirow{2}{*}{ Mean } & \multicolumn{2}{|c|}{$\begin{array}{l}95 \% \text { Confidence } \\
\text { Interval for Mean }\end{array}$} & \multirow{2}{*}{$\begin{array}{c}\mathbf{5 \%} \\
\text { Trimmed } \\
\text { Mean }\end{array}$} & \multirow{2}{*}{ Median } & \multirow{2}{*}{ Std.dev. } & \multirow{2}{*}{ Min. } & \multirow{2}{*}{ Max. } \\
\hline & & $\begin{array}{l}\text { Lower } \\
\text { Bound }\end{array}$ & $\begin{array}{l}\text { Upper } \\
\text { Bound }\end{array}$ & & & & & \\
\hline Átlag & 3.178 & 2.423 & 3.933 & 3.038 & 2.746 & 1.519 & 1.572 & 7.295 \\
\hline MIKR_37.5 & 0.333 & 0.248 & 0.418 & 0.323 & 0.313 & 0.171 & 0.085 & 0.762 \\
\hline MIKR_25.0 & 0.248 & 0.148 & 0.349 & 0.230 & 0.208 & 0.202 & 0.015 & 0.816 \\
\hline MIKR_15.0 & 0.431 & 0.178 & 0.685 & 0.351 & 0.258 & 0.510 & 0.093 & 2.223 \\
\hline MIKR_10.0 & 2.595 & -1.002 & 6.192 & 1.199 & 0.391 & 7.233 & 0.106 & 30.212 \\
\hline MIKR_7.5 & 3.311 & 0.245 & 6.377 & 2.448 & 0.329 & 6.166 & 0.090 & 22.068 \\
\hline MIKR_5.0 & 8.336 & 2.945 & 13.726 & 7.153 & 1.089 & 10.840 & 0.206 & 37.755 \\
\hline MIKR_2.5 & 23.716 & 16.084 & 31.348 & 23.348 & 25.588 & 15.347 & 0.620 & 53.440 \\
\hline MIKR_1.0 & 22.584 & 16.683 & 28.486 & 22.282 & 18.282 & 11.867 & 6.843 & 43.759 \\
\hline MIKR_0.25 & 15.876 & 12.547 & 19.205 & 15.414 & 15.271 & 6.695 & 6.981 & 33.094 \\
\hline MIKR_0.1 & 8.985 & 6.110 & 11.859 & 8.162 & 7.200 & 5.780 & 3.700 & 29.084 \\
\hline MIKR_0.02 & 11.342 & 8.092 & 14.592 & 10.682 & 9.238 & 6.536 & 3.940 & 30.624 \\
\hline MIKR_0.001 & 1.520 & 1.032 & 2.009 & 1.425 & 1.395 & 0.982 & 0.266 & 4.487 \\
\hline
\end{tabular}

8-7. táblázat Az aleurolitok pórusszerkezeti jellemzőinek statisztikai tulajdonságai

\subsubsection{A permeabilitások és a pórusméret- tartományok kapcsolata az egyes üledékes fácieseken belül a higanyos mérések eredményei alapján}

Az egyes fáciesek átlagos pórusméret eloszlási adatait kumulatív diagramon ábrázolva az egyes fáciesek egymástól jól elkülönülten jelennek meg (8-17. ábr). Leghomogénebb, legjobban osztályozott pórusrendszerrel az elosztó medrek üledékei jellemezhetők. A pórusok 37-40\%-a 75-95 mikron közötti értéket vesz fel. Nincs 0,65 mikronnál kisebb pórus. A 2 mikronnál kisebb pórusok aránya mindössze 5\% körüli (8-17. ábr).

A természetes partgát- meder együttesek üledékei pórusméret eloszlásának módusa 6080 mikron közé esik. A 2 mikronnál kisebb pórusok aránya kevéssel alacsonyabb, mint a medrek esetében.

A mederáttörés-mederfelhagyás homokos üledékeiben a pórusok mintegy 50\%- a 40 mikronos pórusméret alatti pórusok formájában van jelen. Mindössze a pórusok $20 \%$-a nagyobb, mint 50 mikron. Ennek ellenére a 2 mikronnál kisebb pórusméretek csak 3\%-ban vannak jelen. A progradáló mederáttörések üledékei pórusainak körülbelül 30\%-a esik 10-15 mikron közé, és 20\%-a kisebb, mint 2 mikron. A vizsgált fáciesek, és átmeneti fáciesek közül itt jelennek meg a legkisebb, 0,007 mikronos pórusok (8-17. ábr).

A mederáttörési lóbák pórusméreteinek kumulatív eloszlása a progradáló mederáttörésekéhez meglehetősen hasonló, azonban rosszabbul osztályozott, sőt a 2 mikronnál kisebb pórusméretek aránya is kiugróan magas, mintegy $40 \%$. Ez a gyakorlatban 
azt jelenti, hogy pórusainak 40\%-ában a kétfázisú folyadékáramlások nem tudnak végbemenni. Ez az üledék genetikájából következő heterogén szemcseméret eloszlásban gyökerezik. Ehhez természetesen később egyéb, posztszedimentációs hatások is hozzáadódhattak. Az osztályozottság hiánya a szemcse és a pórusméret eloszlást is rontja, és így a porozitásra és a permeabilitásra is negatívan hat.

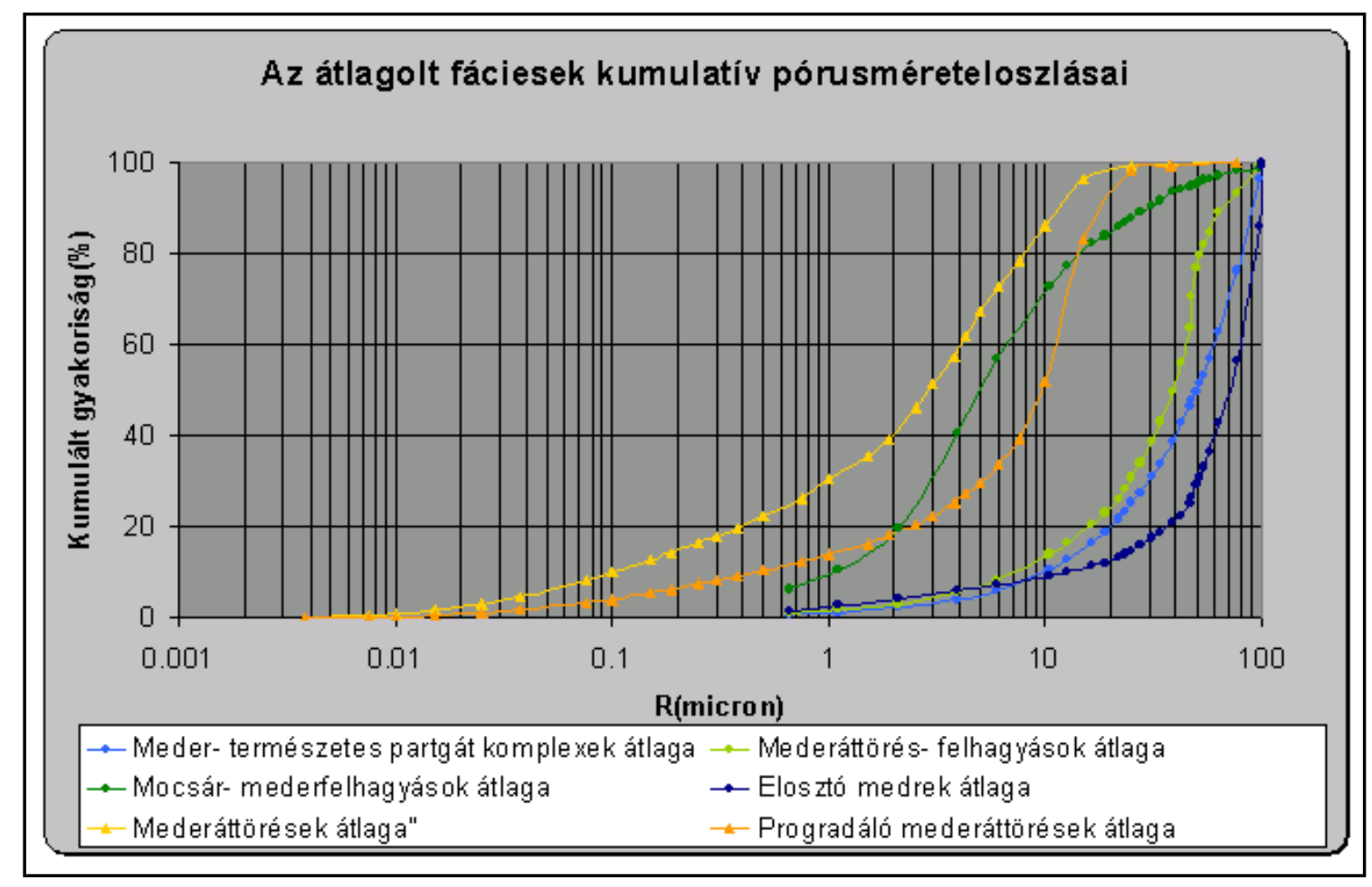

8-17. ábra Az egyes fáciesek átlagolt kumulatív pórusméret eloszlási görbéi

A 8-18. ábra 8-19. ábra szemlélteti az egyes fáciesek csoportosulását az átlagos pórusméret és a permeabilitások kapcsolatában. Mindkét esetben egy erős, pozitív irányú korreláció áll fenn a két tulajdonság között, mely azt sugallja, hogy a felhalmozódásnak erőteljes hatása érvényesül a pórusrendszer kialakításában. Néhány adatpont kevésbé illeszkedik az eloszlásba. Ezek azok a minták, melyek a meghatározott fáciestől vagy mintázási hiba, vagy a fácieshatárokhoz közeli helyzetük miatt térnek el.

A medri áramlásokhoz, áramló vízből történő kiülepedéshez valamilyen formában kapcsolódó minták a diagram jobb felső negyedében, míg az inkább szuszpenzióból történő kiülepedésből származó minták a bal alsó negyedben foglalnak helyet. Értelemszerűen a kettő közötti átmenetet a diagram középső része jelenti. 


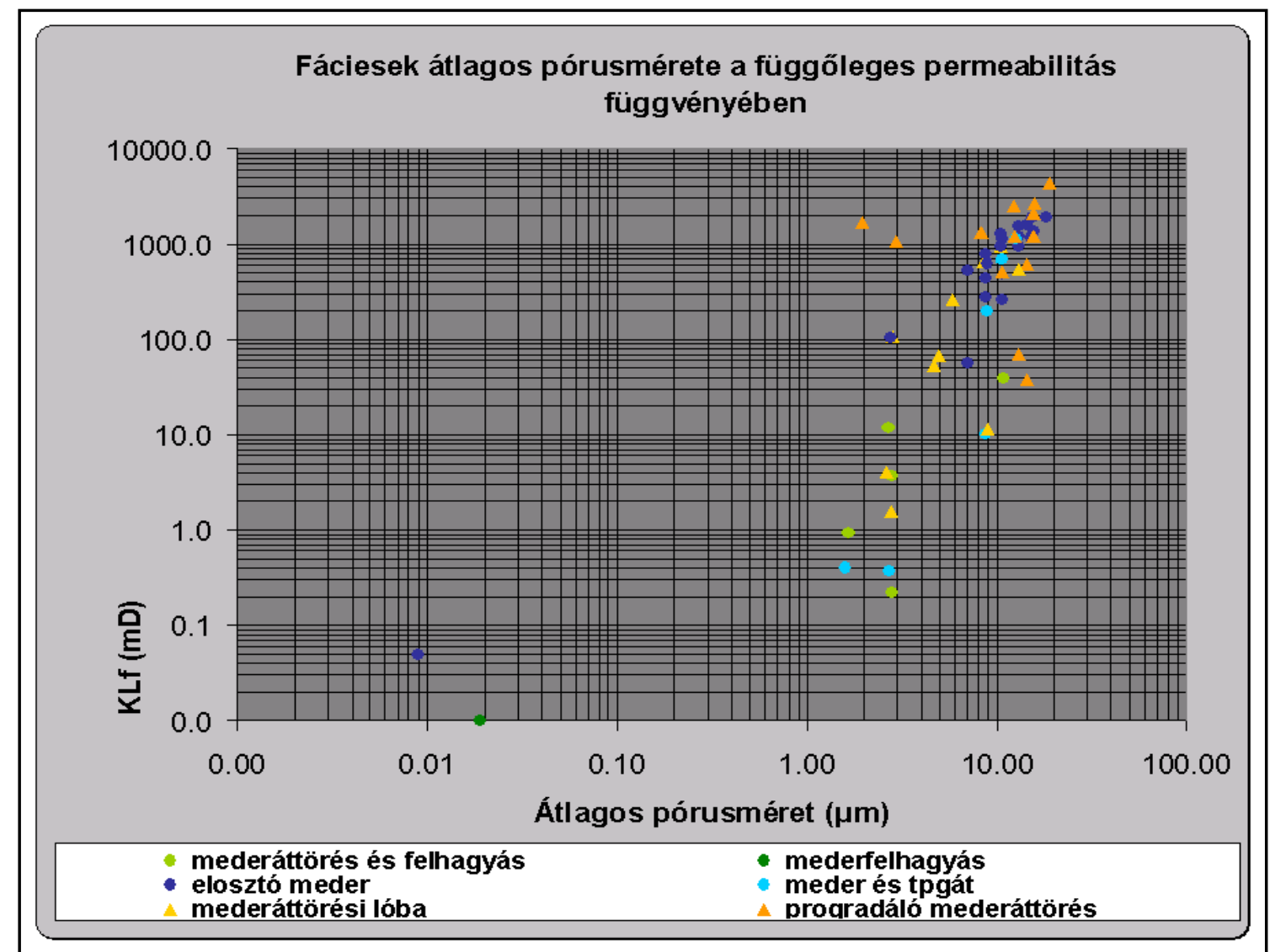

8-18. ábra A függöleges permeabilitás és az átlagos pórusméretek kapcsolata az egyes fáciesekben

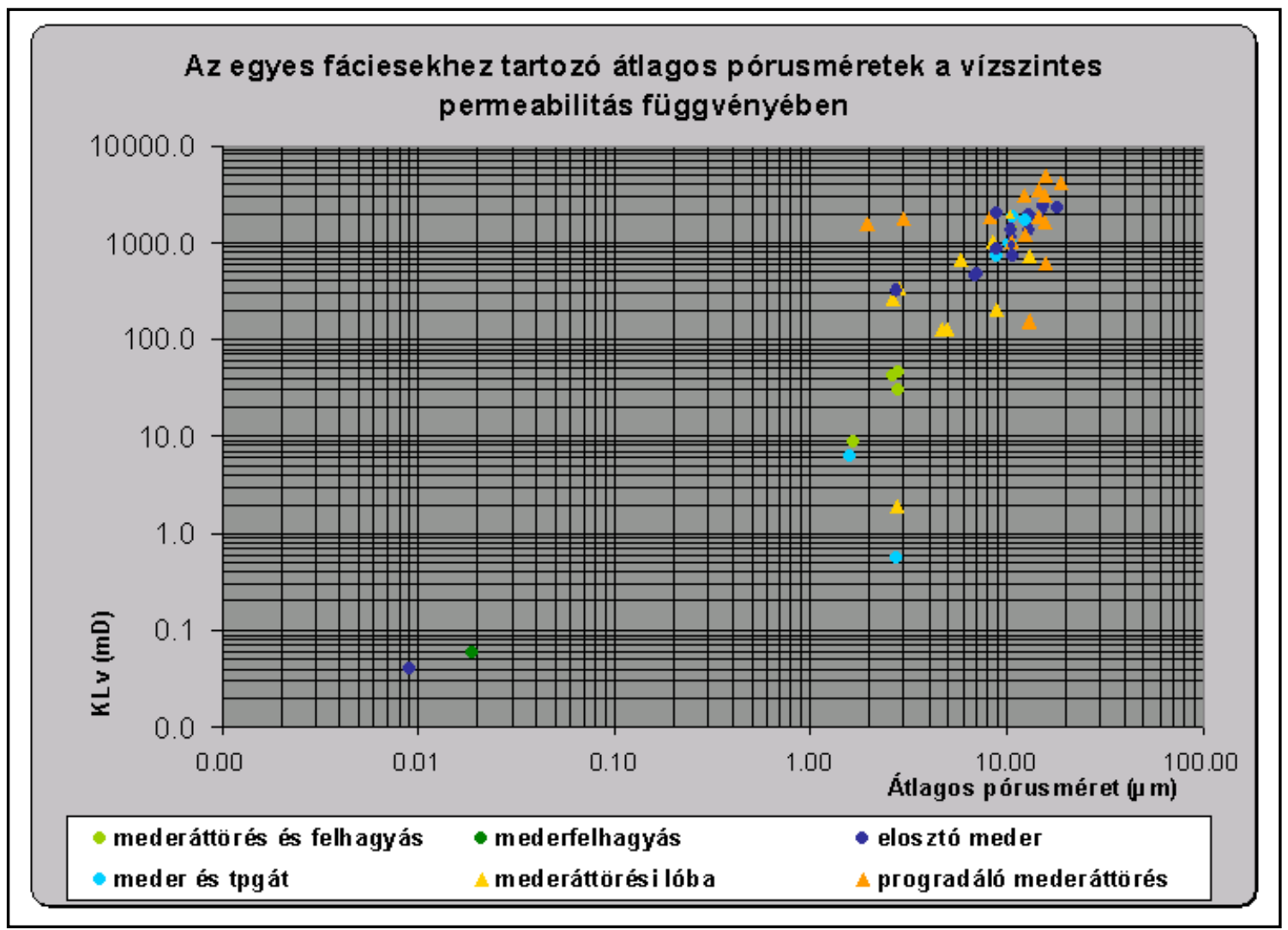

8-19. ábra A vízszintes permeabilitás és az átlagos pórusméretek kapcsolata az egyes fáciesekben 
Fontos megjegyezni, hogy a nem átlagolt, mintánkénti szemcseméret eloszlási görbék, melyek az V-31 - V-36. mellékletekben tekinthetők meg, első pillantásra egymáshoz nagyon hasonlónak tünhetnek annak ellenére, hogy más fácieshez tartoznak, így önmagukban kevéssé alkalmasak fáciesmeghatározásra. Az átlagolás segítségével kapott eredmény a későbbiek során továbbfejlesztve, petrofizikai tulajdonságok bevonásával azonban alkalmasak lehetnek erre a feladatra is.

Az egyes üledékes fáciesekhez tartozó minták permeabilitás értékeit a pórusméret tartományok eltérő módon határozzák meg (V-37. melléklet). A meder és természetes partgát komplex üledékeiben a kétirányú permeabilitást a 10 mikronnál nagyobb makropórusok növelik. A vízszintes permeabilitást a 2,5 mikronnál kisebb, a függőleges permeabilitást az 1 mikronnál kisebb mikropórusok csökkentik (V-37. melléklet).

Mederáttörés és felhagyások üledékeiben a permeabilitások a mikropórusok számának növekedésével romlanak. Mindkét permeabilitás növekedésében meghatározó szerepe van az 5-15 mikron közötti, valamint a 37,5 mikronnál nagyobb pórusméreteknek (V-37. melléklet).

A mederáttörési lóbák esetében a permeabilitás növelésében a 37,5 mikronnál nagyobb óriáspórusok nem vesznek részt, csak a 7,5-25 mikron közé eső pórusok. A mért tulajdonságokat a 2,5 mikronnál nagyobb pórusok rontják (V-37. melléklet).

A progradáló mederáttörésekben a vízszintes és a függőleges permeabilitás közötti korrelációs együttható értéke mindössze 0,5 , azaz a két irányban mért paraméter egymástól jelentősen eltérhet. A vízszintes és függőleges permeabilitást a 0,015 mikronnál kisebb pórusok rontják. A függőleges permeabilitást a 15 mikronnál nagyobb pórusok növelik (V-37. melléklet).

Az elosztó medrekben mindkét permeabilitást növelik a 10-25 mikron közé eső pórusok, és csökkentik az 5-7,5 illetve vízszintes permeabilitás esetében a 0,015 mikronos pórusok (V-37. melléklet). 


\subsection{A diagenezis eredményének kvantitatív jellemzése}

A 8.5.3. alfejezetben tárgyalt faktoranalízis alapján már utalást tettünk a diagenezis szöveti, kőzetfizikai tulajdonságokra gyakorolt hatására, mely szerint a vizsgált tulajdonságokat, mint porozitás, permeabilitás, pórusméretek eloszlása, csak igen kis százalékban magyarázza a diagenetikus faktor. Ennek hatása abban nyilvánul meg, hogy az 5 mikronos pórusméretek előfordulásának gyakorisága a 10 mikronos pórusméretek rovására nő.

A karbonát ásványok hatása az ötödik és a hatodik faktor hatásában nyilvánult meg. Az analízis eredménye alapján a karbonát ásványok a 2,5-5 mikron közötti pórusméret tartományt szükítik, míg a 0,1-0,235 mikron közé eső tartomány gyakoriságát növelik.

Ezek alapján feltételezhető, hogy a karbonát ásványok hatása többnyire csak a mikropórusok szintjén jelentkezik. Ezt alátámasztani látszanak a pásztázó elektronmikroszkópos vizsgálatok is, melyek kimutatták, hogy a mikropórusok az átalakulóban, lebomlóban lévő, főleg karbonát ásványokban vannak jelen nagy számban. A mintákban a törmelékes részt ezek a lebomló és már helyben keletkezett ásványok alkotják (MOL NyRt.) Az V-38 és V-39. mellékletek átalakuló karbonátokat és annak nyitott pórusait szemléltetik.

A homokkövek másodlagos porozitásának kifejlődése gyakran a karbonát ásványok (kalcit, dolomit, sziderit) mezogenetikus oldódásának (leaching) eredménye, mely a vizsgált minták egy részében is nyomon követhető. Mivel a karbonát tartalom föleg törmelékes formában van jelen, a porozitást, és a permeabilitást is negatív irányban befolyásolhatja. Ezt igazolják a kőzetfizikai paraméterek és a karbonát tartalom közötti kapcsolatot vizsgáló grafikonok is (V-40. és V-41. mellékletek) azzal a kiegészítéssel, hogy a vizsgált paraméterek között csak gyenge kapcsolat van. A homokkövekben mind a kalcit, mind a dolomit tartalom növekedése a permeabilitásokra és a porozitásra is negatívan hat. Az aleurolitok esetében ennek ellenkezője figyelhető meg, mivel itt az autigén karbonát az aleuritnál nagyobb szemcseméretével a porozitást is növeli (V-41. melléklet). 


\section{Megalépték- Mederalakulatok elhelyezkedése a vizsgált területen}

\subsection{A térképezés módszere}

A térképi megjelenítéshez a homoktartalom 0-100\% közötti értékeit 10\%-os növekményü intervallumokba soroltam. A térképezett homoktartalmak az alábbi formában fordíthatók vissza kőzettípusokra:

\begin{tabular}{|l|l|}
\hline Homoktartalom & Üledékes kőzettípus \\
\hline $0-30 \%$ & Finom aleurolit és agyagmárga \\
\hline $31-50 \%$ & Durva aleurolit és kissé homokos durva aleurolit \\
\hline $51-70 \%$ & Homokos durva aleurolit \\
\hline $71-100 \%$ & Finom és apróhomokkő \\
\hline
\end{tabular}

\section{9-1. táblázat A térképezett homoktartalom intervallumok litológiai tartalma}

A kőzettestek genetikai alapú elkülönítése és azonosítása az alábbi szempontok figyelembevételével történt:

- Finom aleurolit és agyagmárga felhalmozódásának optimális körülményeket biztosítanak a mocsári, ártéri környezetek, illetve a mederfelhagyások területei;

- A durva aleurolit és kissé homokos durva aleurolit olyan környezetekben halmozódik fel, mely áramlásoktól gyengén háborgatott. Ilyen feltételek több környezetben is teljesülhetnek, ha nem is állandósuló jelleggel, így maradandó, nagy tömegü felhalmozódást nem minden esetben alakítanak ki. Ilyen lehet például az elosztóközi öblök áramlásoktól gyengén háborgatott területe, a természetes partgát víz alatti részének bizonyos szakaszai, ahol a szuszpenzióból történő kiülepedés megvalósulhat. De ilyen üledék halmozódhat fel egy mederáttörés bevezető szakaszában is, vagy egy mederfelhagyás végső stádiumában. Láthatjuk, hogy az üledék képződésének alapfeltétele több környezethez is kapcsolódhat, így ezeket nem lehet pusztán kőzetminőségbeli alapon azonosítani. Mint ahogy a többi üledékes kőzettípus esetében is, úgy itt még fokozottabban a homokkontúrok formai értelmezése ad támpontot az azonosításhoz.

- A homokos durva aleurolit lerakódásának kedvez a természetes partgát, az elosztóközi öbölkitöltés, a mederáttörési lóba disztális része és a torkolati zátony disztális részének környezete is.

- A finom és apróhomokkő felhalmozódása a legnagyobb szállítási energiák jelenlétét bizonyítja. Az elosztó medrek, mederáttörési lóbák, torkolati zátonyok és progradáló mederáttörések tipikus üledéke. 
A kőzettípus azonban önmagában még nem ad elég alapot a genetikai szempontú elkülönítésre, felismerésre. A homokkontúrok formai vizsgálata alapján viszont nagy bizonysággal felismerhetővé válnak az egyes környezeteket jelző üledéktestek. A kontúrok alakja, azok vertikális nyomon követhetősége nyújt információt az adott üledékes környezetről.

A medrek elnyúló, lineáris formájú üledéktömeget halmoznak fel. Szélességük a néhány métertől az 1 kilométeres szélességig változhat. Mélységük minimum 1-2 méter, maximum 30 méter. Jellemző rájuk a felfelé finomodó szemcseméret, ami a rétegsorokban és a geofizikai szelvényeken nagyon jól nyomon követhető. A nagyobb elosztó medrekhez általában természetes partgát is kapcsolódik, melynek formája követi a meder nyomvonalát. Szélességük néhány métertől a néhány 10 méterig terjedhet. Az elosztó medrek elvégződésében képződő torkolati zátonyok homokos üledékei jellegzetes vese alakjukkal szintén jól elkülönülnek a többi üledékes testtől. Több tíz méteres vastagságban és több négyzetkilométernyi kiterjedésben követhetőek nyomon.

A természetes partgátak zavartalan épülését partgát-áttörések szakíthatják meg, melyek szintén a fő elosztó medrekböl lépnek ki. Jellegzetes elnyúlt, legyező formájukról könnyen felismerhetőek. Hosszuk néhány 100 métertől a 15-20 km- t is elérheti a tápláló elosztó meder nagyságától, és a víz illetve üledékutánpótlás mértékének függvényében

$\mathrm{Az}$ egyes genetikai üledéktestek elkülönítése a fenti szabályszerüségek figyelembevételével történt.

\subsection{A torkolati zátonyok és mederalakulatok jellemzése}

$\mathrm{Az}$ egyes mederalakulatok sok esetben egymással kapcsolódva jelennek meg a homoktartalom térképeken, vagy egy torkolati zátonyon kifejlődve, bevágódva progradálnak tovább. Emiatt kizárólagos elkülönítésük sokszor lehetetlen, ezért több esetben a rendszerbeli megközelítés lehetőségével éltem. A vizsgált területen az alábbi mederalakulatokat magába foglaló üledékes genetikai rendszereket különítettem el:

- Dél- délnyugati irányból progradáló torkolati zátony és mederegyüttes

- Északi torkolati zátony

- Keleti irányból progradáló torkolati zátony és mederegyüttes

- Rövidebb szakaszú elosztó medrek, felhagyott medrek, melyek néhol kapcsolódnak egymással

Az imént vázoltak részletes bemutatását a következő alfejezetek tartalmazzák. 


\subsubsection{D-DNy-i torkolati zátony- mederegyüttes fejlődésmenete}

A PT alatt 27-22 méteres mélységben a homoktartalom metszetfelületein a nagyobb homoktestek vizsgálata során egy DNy-i torkolati zátonyból ÉK-É-i irányba progradáló meder ismerhető fel, melynek maximális hossza 4,5-5 km. Homokos üledékei maximum 5 méter vastagságban követhetők nyomon. A homoktest a gáz- víz határt a permeábilis tető alatt $26 ; 25,5 ; 25 ; 24,5 ; 24 ; 23,5 ; 23$; és 22,5 méter mélységben érinti. Ez a meder összekapcsolódik egy, a tetővonallal párhuzamos irányban kiépült másik mederrel a permeábilis tető alatti 22,5-23 méteres mélységben. A területen az üledékutánpótlás fö iránya DNy- ÉK.

A PT alatt 21,5 méter mélységben az előző meder É-ÉNy-i ágának visszahúzódása, feltöltődése jellemző, és a meder visszaszorulása, kisméretű torkolati zátonnyá fejlődése látszik. A PT alatt 21,5-20,5 méter mélységben hossza: $1 \mathrm{~km}$, szélessége: 0,7 km. Homokos üledékei a metszetsíkokon 1 méter mélységig követhetők nyomon. A mederalakulat a GVH-t nem érinti.

A PT alatt 20,0- 17,5 méter között a torkolati zátonyból újabb progradáló meder kifejlődését mutatják a homoktartalom- térképek. A kisméretü torkolati zátony ÉK felé nyomul elöre, és belőle egy elosztómeder alakul ki, melynek hossza: 1,5- 2 km, szélessége minimum 200, maximum 500 méter. A homoktest a GVH-t érinti: a permeábilis tető alatt 17,5 méterrel (9-1. ábra).

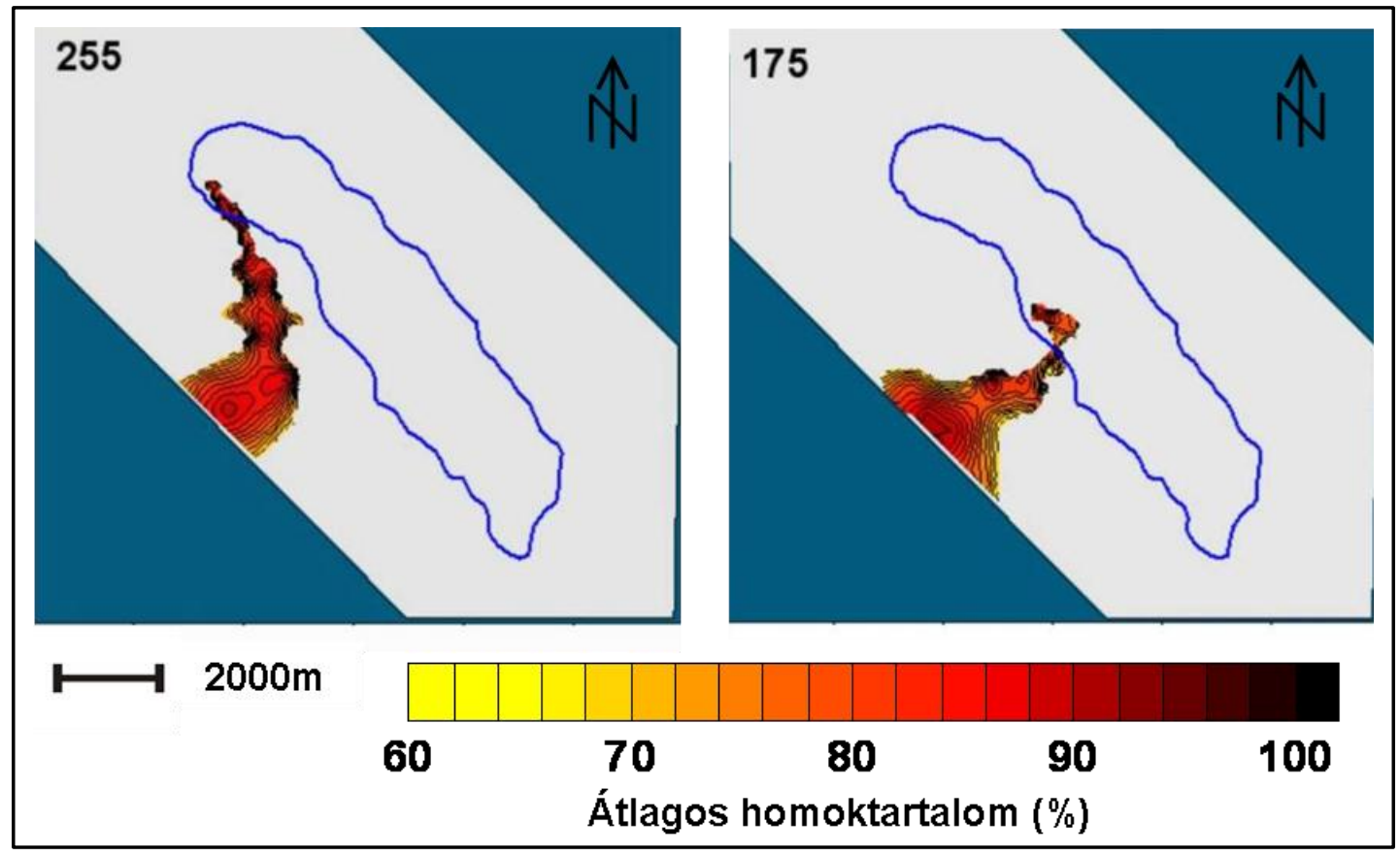

9-1. ábra A D-DNy-i torkolati zátony-meder rendszer helyzete a PT alatt 25,5 és 17,5 méterrel 
A PT alatt 17,0- 11,5 méterrel a torkolati zátony kiterjedése DK-i irányba haladva nő. Belőle több elosztómeder nyúlik a GVH irányába, és el is érik azt, de maga a torkolati zátony nem. Ebben a mélységben hossza: 1-1,5 km, szélessége: 3-3,5 km. Üledékeinek vastagsága eléri az 5,5 métert. A permeábilis tető alatt 11,5 méter mélységben a torkolati zátony területe lecsökken és a déli területekre szorul vissza (9-2. ábra).

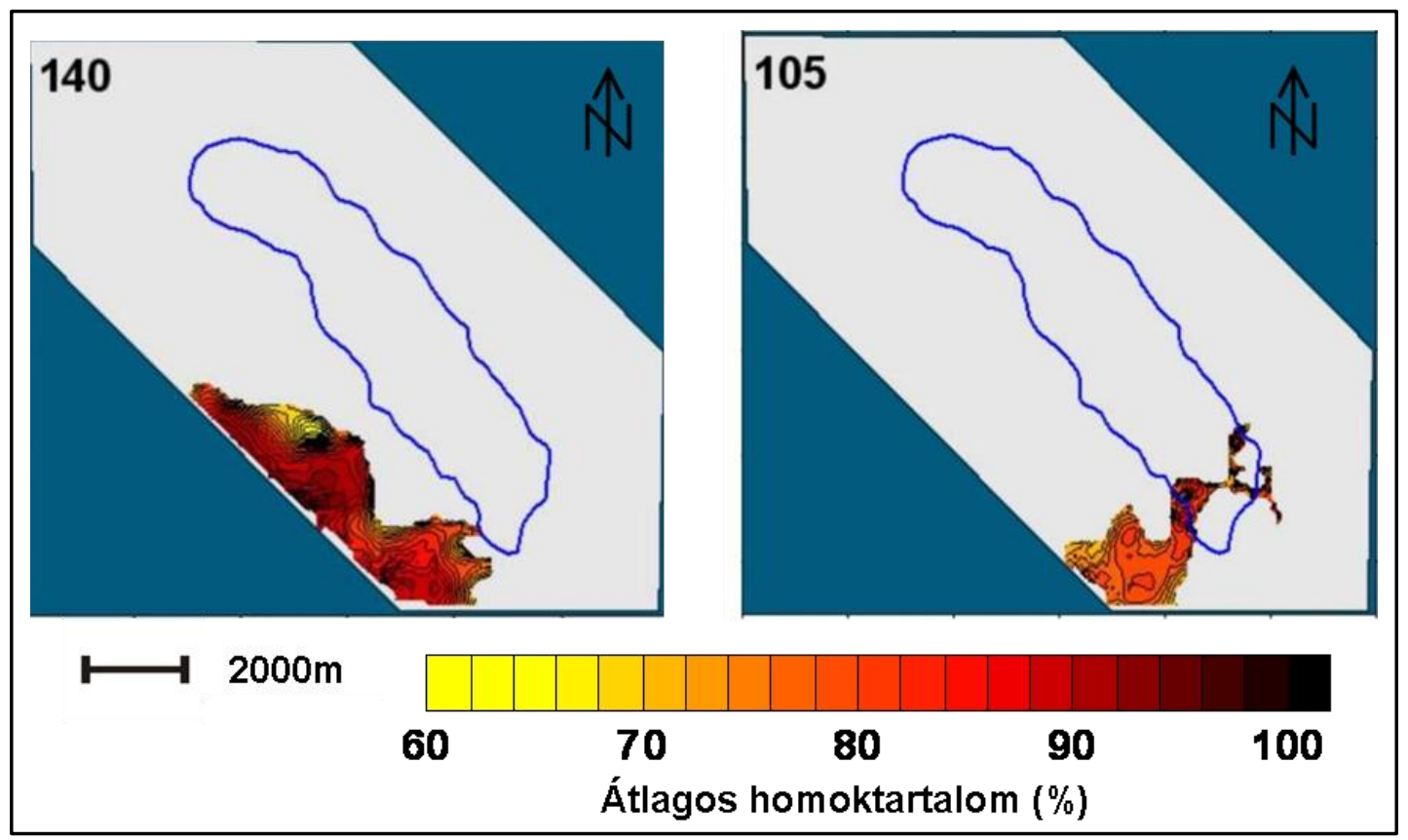

9-2. ábra A D-DNy-i torkolati zátony-meder-rendszer helyzete a Pt alatt 14 és-10,5 méter között

A PT alatt 11,0- 7,5 méter között a délen megmaradt, kisebb kiterjedésü torkolati zátonytestből (6-12. melléklet,110, 105, 100, 075) egy elosztómeder kialakulása és kiépülése látszik, majd fokozatos feltöltődés veszi kezdetét (9-3. ábra). Az elosztómeder hossza maximum 2 km. Szélessége minimum 50-80 m, maximum 300 méter lehetett. Üledékeinek vastagsága maximum. 3 métert ért el a legdélebbi részen. 
A permeábilis tető alatt 9,5 méter mélységben az elosztómeder északi ága fokozatosan lefüződik , majd feltöltődik, végül a déli területekre húzódik vissza (9-3. ábra).

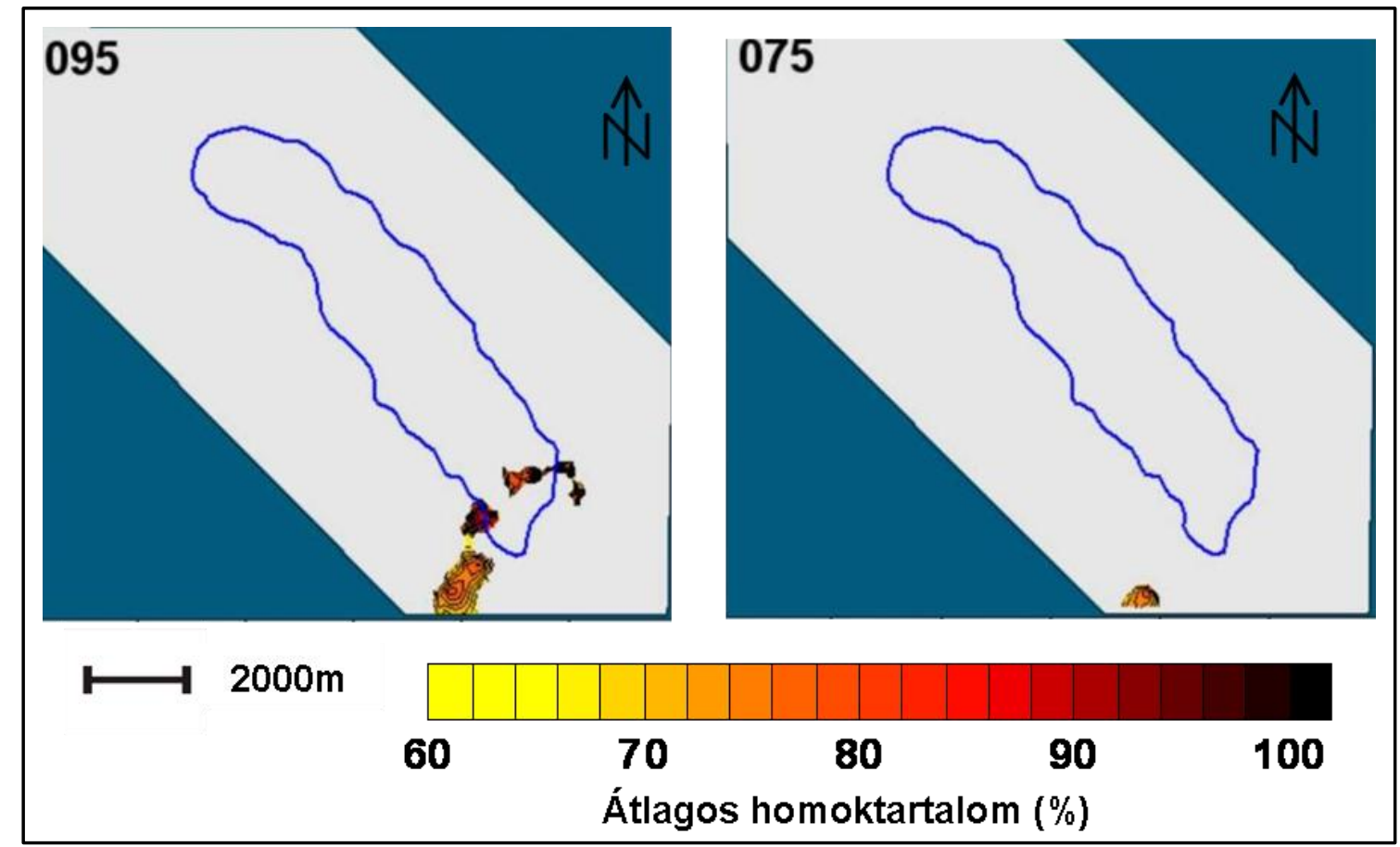

9-3. ábra A D-DNy- i torkolati zátony-meder-rendszer fejlödése a PT alatt 9,5 és-7,5 méter között

\subsection{2 Északi torkolati zátony fejlődése}

\subsubsection{Permeábilis tetö alatt 26,0-20,0 m}

A tető alatt 26-20 méter között egy váltakozó területi kiterjedésü torkolati zátony ismerhető fel, mely az ÉK- ről érkező ingadozó víz- és üledékutánpótlás miatt alakult ki. Az üledékutánpótlás fő iránya ekkor DNy- ÉK-i lehetett. Az üledékképződés súlypontja ebben az időszakban a terület DNy-i területére koncentrálódik. Az ÉK-i területek finomszemü üledékképződési időszaka jellemző, míg DNy-on homokos képződmények halmozódnak fel. Ebben az időszakban az egész terület DK-i részén aleurit- és agyagmárga képződés folyik (VI-2. melléklet)

\subsubsection{Permeábilis tető alatt 19,5-10,5 m}

Egységes lepelhomok- képződési időszak veszi kezdetét, amely elmossa a regionális fontosságú, nagyobb homoktestek kontúrjait, így ezek a homoktartalom metszetsíkok térképein kevésbé ismerhetőek fel. 


\subsubsection{Permeábilis tetö alatt 11,0-7,0 m}

A korábban kialakult torkolati zátony progradációjának nyomai látszódnak a PT alatti 11-7 méter mélységben. A progradáció DNy- i irányba történik. A torkolati zátony maximális szélessége: 1,5-1,8 km, maximális hosszúsága 1,5 km. (VI-3. és VI-4. melléklet). Homokteste a GVH-t eléri: 9,0- 6,5 tető alatti mélységintervallumban (A disztális torkolati zátony üledékei, és a rajta kialakult elosztómedrek kisebb mélységekben is elérik). Üledékeinek vastagsága 4-5 méter (VI-3. és VI-4. mellékletek).

\subsubsection{Permeábilis tetö alatt 6,5-4,0 m}

Az előzőekben tárgyalt torkolati zátony fokozatosan észak felé hátrál, DK-i részén feltöltődik. A rajta kialakult elosztómeder északon eléri a GVH-t a permeábilis tető alatti 4 méteres mélységben (VI-5. melléklet). 


\subsubsection{Keleti torkolati zátony és mederegyüttes fejlődésmenete}

\subsubsection{Permeábilis tetö alatt 9,0-4,0 m}

Az adott mélységben megjelenő torkolati zátony a terület feltöltődése szempontjából alárendelt fontosságú. Egy keletről nyugat-északnyugat irányba progradáló torkolati zátony, majd rajta kifejlődött elosztó medrek jelennek meg (9-4. ábra). Maximális hossza $4 \mathrm{~km}$, maximális szélessége $3 \mathrm{~km}$. Üledékei maximum 5 méteres vastagságban követhetők nyomon. A zátonytestbe vágódó medrek a GVH-t is elérik 8,0-4,0 méteres PT alatti mélységintervallumban (9-4. ábra és VI-1. melléklet).

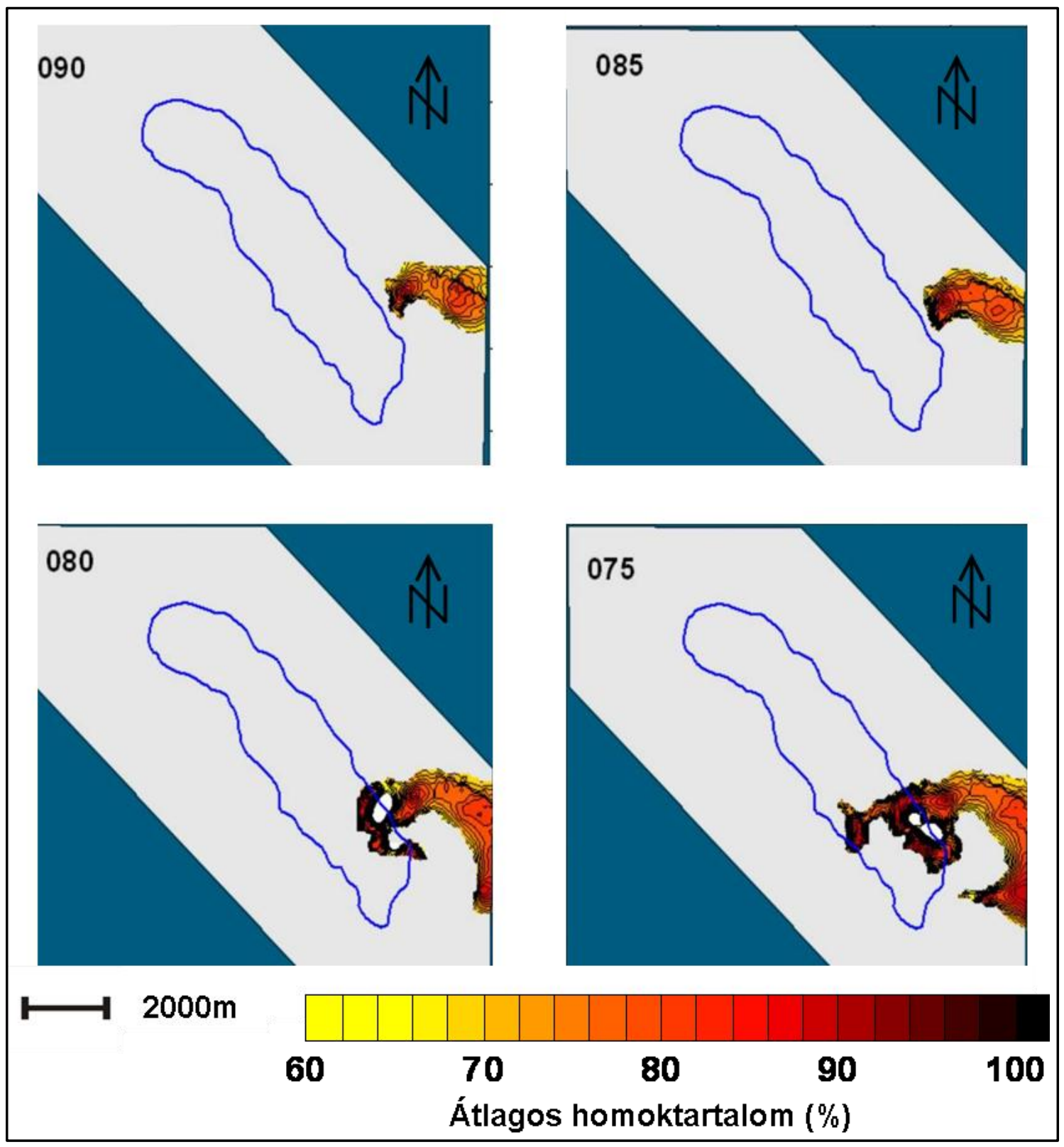

9-4. ábra A keleti torkolati zátony fejlödése a PT alatt 9- 7,5 méteres mélységben 


\subsection{A gáz- folyadék határ és az egyes mederalakulatok egymáshoz viszonyított helyzete}

A telepre jellemző szerkezeti tulajdonságoknak az egyes kutak müvelési szabályozása szempontjából döntő szerepe van.

A kőzettesten belüli áramlási viszonyok egzakt ismerete a maximális kitermelhetőség, a biztonságos tárolás és lefejtés érdekében elengedhetetlen. Az áramlásviszonyok üledékes genetikai alapokon nyugvó közelítése jól kiegészítheti a tárolóról szerzett eddigi információkat.

Továbbiakban arra keresek választ, hogy az eddig megismert homoktestek milyen hatással lehetnek a gáz- folyadék határra, illetve a gázsapka peremterületén uralkodó felszín alatti áramlásokra.

Ehhez meg kell vizsgálnunk az egyes áramlási szempontból esetlegesen befolyásoló tényezőként müködő homoktestek valamint a gáz- fluidum határ egymáshoz viszonyított helyzetét.

A GVH-t érintő homoktesteket két nagy csoportra osztva először vizsgáljuk meg, hogy a kőzettesten belül hol érintik, vagy metszik ezek a homoktestek a GVH-t az eddigiek ismeretében.

\subsubsection{GVH-t érintő medrek}

9.3.1.1 Meder - 1

A meder DNy-ÉK-i irányultságú elosztómeder. A gáz-folyadék határt a PT alatt 6-7,5 méter közötti mélységintervallumban metszi (VI-7. melléklet, 060, 065, 070, 075).

\subsubsection{Meder - 2}

É-ÉNy - D-DK-i csapásirányú, kezdetben kis, majd növekvő kiterjedésű meder, mely a PT alatt 14-15 méter között a gázsapka területére is mélyen benyúlik, és kisebb elosztómedrekkel szövevényes hálózatot alkot.

Valószínüsíthető a PT alatt 14,5 méterrel a meder és a gázsapkától É-ÉK-i irányban található torkolati zátony közötti kapcsolat.

A meder a gázsapka területéről É-i irányban kilépve feltöltődik.

A gáz- folyadék határt a PT alatt 11-19,5 méter mélységintervallumban metszi (VI-8., VI-9. és VI-10. melléklet).

\subsubsection{Meder - 3}

D-DNy-i, kisebb méretű torkolati zátonyba bevágó és É felé progradáló meder, melynek a gázsapka területén lévő (VI-11. melléklet, 225, 230) magas homoktartalmú 
mederüledékekkel, illetve az onnan ÉNy felé, a gázsapka területéröl kilépő mederalakulatokkal képzett kapcsolata valószínüsíthető (VI-11. melléklet, 230-260-ig).

A PT alatt 26,5-27 m mélységek között a meder még nem éri el a GVH-t, de valószínűsíthetjük egy ÉNy-i torkolati zátonyon kifejlődött, gázsapka felé tartó mederrel való későbbi összeolvadását (VI-12. melléklet, 265, 270.).

\subsubsection{GVH-t érintő torkolati zátonyok}

A 9-2. fejezetben már megtörtént a torkolati zátonyok rövid jellemzése, ezért itt csak a GVH-hoz viszonyított helyzetüket pontosítom.

\subsubsection{Keleti torkolati zátony}

A GVH-t a PT alatt 4-7,5 méter mélységintervallumon belül metszi (VI-6. melléklet, VI-7. melléklet, 060, 065, 070, 075).

\subsubsection{2 Északi torkolati zátony}

A gáz- folyadék határt a PT alatt 7-9 méteres mélységintervallumok között metszi (VI7. melléklet, 070, 075 és, VI-4. melléklet 070-090).

\subsubsection{D-DNy-i torkolati zátony}

A GVH-t csak érinti a PT alatt 14 méteres mélységben, valamint a PT alatt 11-12,5 m mélységintervallumon belül, de a PT alatt 10-10,5 mélységek között a belöle kifejlődő keskeny elosztó meder a gázsapka területét a déli részen átszeli (VI-8. melléklet, 100, 105, 110, 120, 125, valamint VI-9. melléklet 140). 


\subsection{Lehetséges áramlásviszonyok a gázsapka peremterületén}

A legkiterjedtebb, nagy vastagságban kifejlődött homoktestek a vizsgált terület peremi részein foglalnak helyet, mivel ide korlátozódnak a fentebb említett torkolati zátonytestek, melyek magas homoktartalmuk mellett a legnagyobb mélységben követhetök nyomon a homoktartalom térképek alapján.

Mindemellett fontos megjegyeznünk, hogy termelés - tárolás szempontjából perspektivikus homoktestek kijelöléséhez a maximális homokvastagság nem elegendő paraméter. Figyelembe kell vennünk az effektív, azaz a hatékony porozitást és a jó permeabilitást is. Mindezek kellő mértékü egybeesése esetén mondhatunk csak véleményt az adott területről. Ezeket a tulajdonságokat az üledékes környezet és az általa kialakított üledékes fácies a szállító közeg energiaviszonyain és a felhalmozott üledékek geometriáján keresztül határozza meg. Később a fenti folyamatok eredményét diagenetikus és posztdiagenetikus hatások is módosíthatják.

A kőzettípus térbeli változékonysága a porozitás és permeabilitás laterális kiterjedésének változékonyságával együtt, valamint az üledékes testek közötti fizikai kapcsolat jellege döntően befolyásolja az üledékes kőzettest egészében végbemenő áramlásokat, áramlási útvonalakat. Így az eltérő üledékes fáciesek a fluidum áramlások szempontjából is egymástól eltérő módon viselkedhetnek.

A magas homok és alacsony aleurolit és agyagtartalmú üledékekből felhalmozódott kőzettestek, mint a mederalakulatok homokos üledékei, a zátonytestek, magasabb porozitással és permeabilitással, és viszonylag nagy laterális kiterjedéssel párosulnak. A mederhomokok esetében mindezek mellé a mederrel párhuzamos áramlási irányultság is társul. A mederüledékek esetenkénti, összeolvadási felszíneken keresztül történő összefogazódása a vertikális fluidum áramlásokat megkönnyíti. A torkolati zátonyok progradáló jellege és a rajta kifejlődött, üledékeibe bevágó kisebb elosztó medrek szintén hasonló tulajdonságokkal rendelkeznek.

A szintén magas homoktartalmú, jó tároló tulajdonságokkal bíró mederáttörési lóbák azonban áramlástani szempontból egymástól elszigetelt lencséket alkotnak. Megjelenésük a vizsgált területen a torkolati zátonyok előtereiben a leggyakoribb. Kiterjedésük nem számottevő, azonban jellemzően egymással, és kisebb elosztó medrek üledékeivel, valamint a torkolati zátonyok frontvonalában elhelyezkedő üledékekkel sok esetben összefogazódnak.

A természetes partgát finomszemü üledékei magas aleurolit tartalmuk miatt vertikális irányban áramlási akadályként viselkedhetnek, mivel a homokosabb részeket többé- kevésbé összefüggő, vékony lepelként választják el egymástól, és a meder homokos üledékeitől is. 
A vizsgált terület ÉNy-i és DK-i szárnyán nagy kiterjedésben, valamint kisebb kiterjedésben az elosztó medrek közötti területeken is a regionális agyagmárga képződési időszakok következményeként agyagos aleurolit és agyagmárga halmozódott fel. Ezek a mocsári, illetve pangóvízi üledékek áramlási gátként funkcionálhatnak a folyadékáramlások szempontjából.

$\mathrm{Az}$ 5. fejezetben megismert felhalmozódási genetika, és a 8 . fejezetben tárgyalt petrofizikai tulajdonságok közötti kapcsolatok ismeretében megállapíthatjuk, hogy az átlagos porozitás térképen az északkeleti és a délnyugati torkolati zátonyok homokos üledékei a kőzettest átlagos porozitás térképén (9-5. ábra) magas átlagporozitású területként jelentkeznek, azaz itt várható a legmagasabb permeabilitás is. A keleti torkolati zátony üledékeinek átlagos porozitása az előző kettőhöz viszonyítva kisebb.

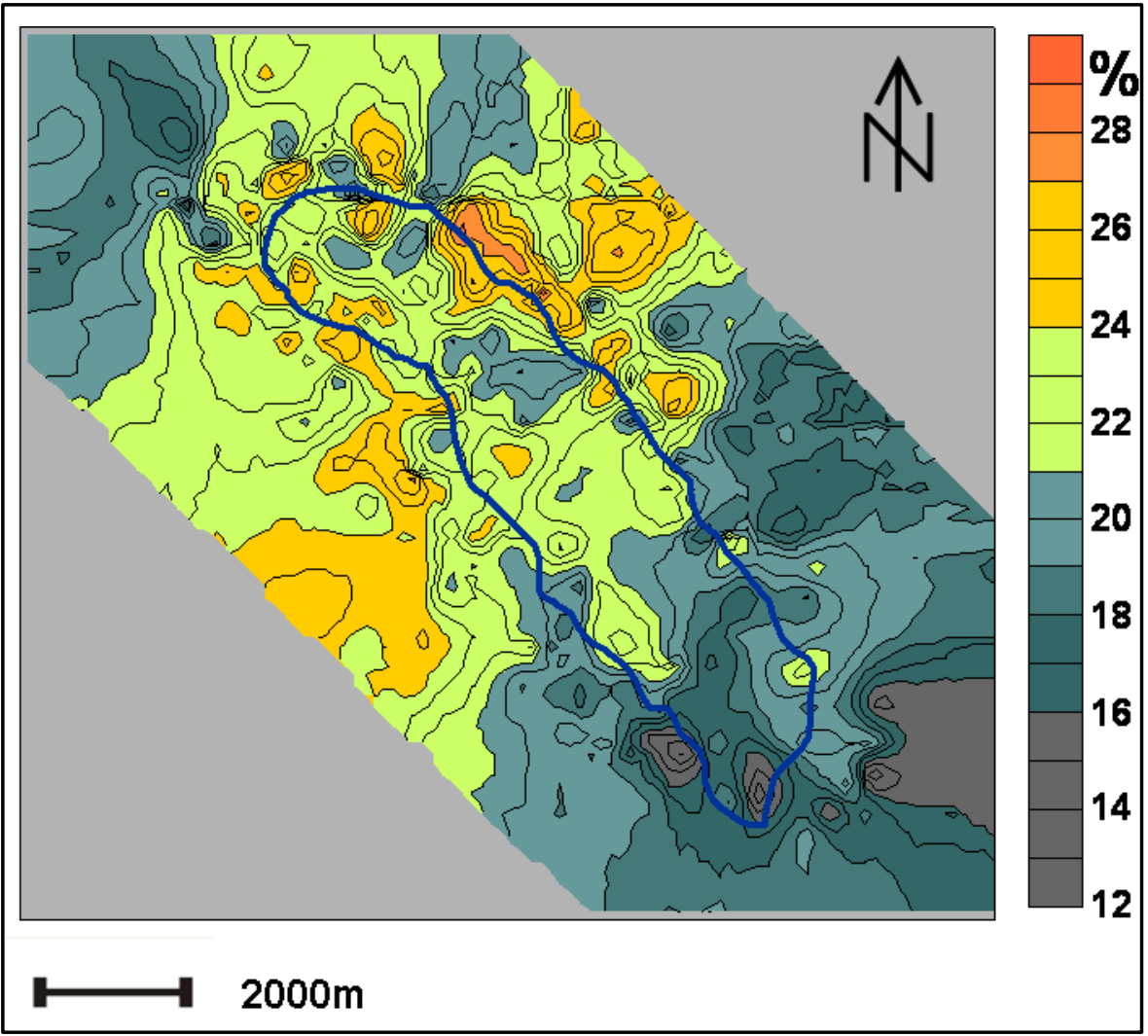

9-5. ábra Az átlagos porozitás kontúrtérképe 
A magas átlagos porozitás- és permeabilitás értékekhez társuló nagy homokvastagság a vizsgált fáciesek kőzettesten belüli meghatározó jellegét mutatja (9-6. ábra).

Az átlagos homoktartalom és az átlagos porozitás kontúrtérképéből készített kompozit térkép szemlélteti, hogy a két legnagyobb kiterjedésű torkolati zátony, és a hozzá kapcsolódó - a zátonyprogradáció során a homoktestbe bevágódó - elosztó medrek felhalmozódásai jelentik a legjobb (23\% fölötti) porozitású, legnagyobb vastagságban felhalmozódott üledékeket. Az ÉNy-i és a DK-i szárnyon főleg a $20 \%$ alatti porozitással jellemezhető üledékek vannak jelen.

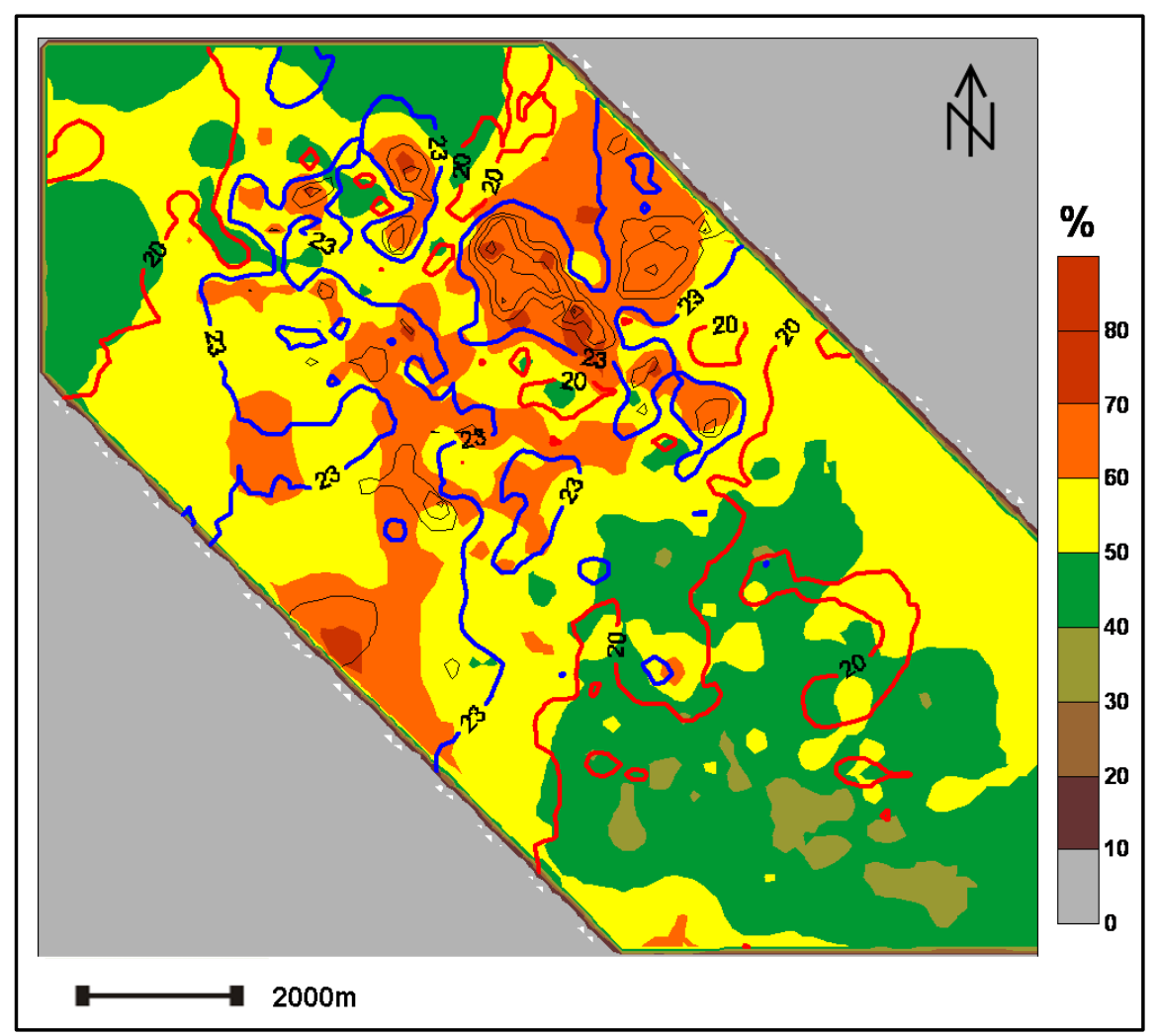

9-6. ábra Az átlagos homoktartalom és a 20 és $23 \%$-os porozitáshoz tartozó izovonalak

A terület effektív, azaz hasznos rétegvastagságát ábrázoló térkép a tároló rétegek vastagságát szemlélteti (9-7. ábra). Ez a délnyugati és keleti torkolati zátony- meder rendszerek üledékeinek meghatározó jellegét mutatja. Az északi torkolati zátony valamivel kisebb effektív vastagságot mutat. Mindemellett jól látható, hogy a torkolati zátonyok előtereiben egy többé- kevésbé összefüggőnek látszó, keskeny, ÉNy-DK-i csapású, legnagyobb effektív vastagságú terület húzódik. Ez valószínüsíthetően a torkolati zátonyok lejtőin a mélyebb területekre csúszó üledékekből, valamint a mederalakulatok, és mederáttörési lóbák összeolvadásából kialakult üledékes sáv lehet. 
Áramlástani szempontból, mint ahogyan azt az effektív vastagság térképre illesztett áramlásos vektortérkép is mutatja, a peremi részek felől a gázsapka felé tartó áramlások a torkolati zátonytestek irányából, és a rajtuk kialakult medrek vonalából indulhatnak el, azonban a gázsapkát valószínűsíthetően nem érik el. Egyedül az É-ÉNy-i peremterületen kell tartani beáramlásoktól. A gázsapka területén lévő mederáttörési lóbák üledékes kőzettestei áramlástanilag egymástól elszigetelten jelennek meg, a belölük kiinduló áramlási vonalak rövidek, gyorsan elvégződnek (9-7. ábra).

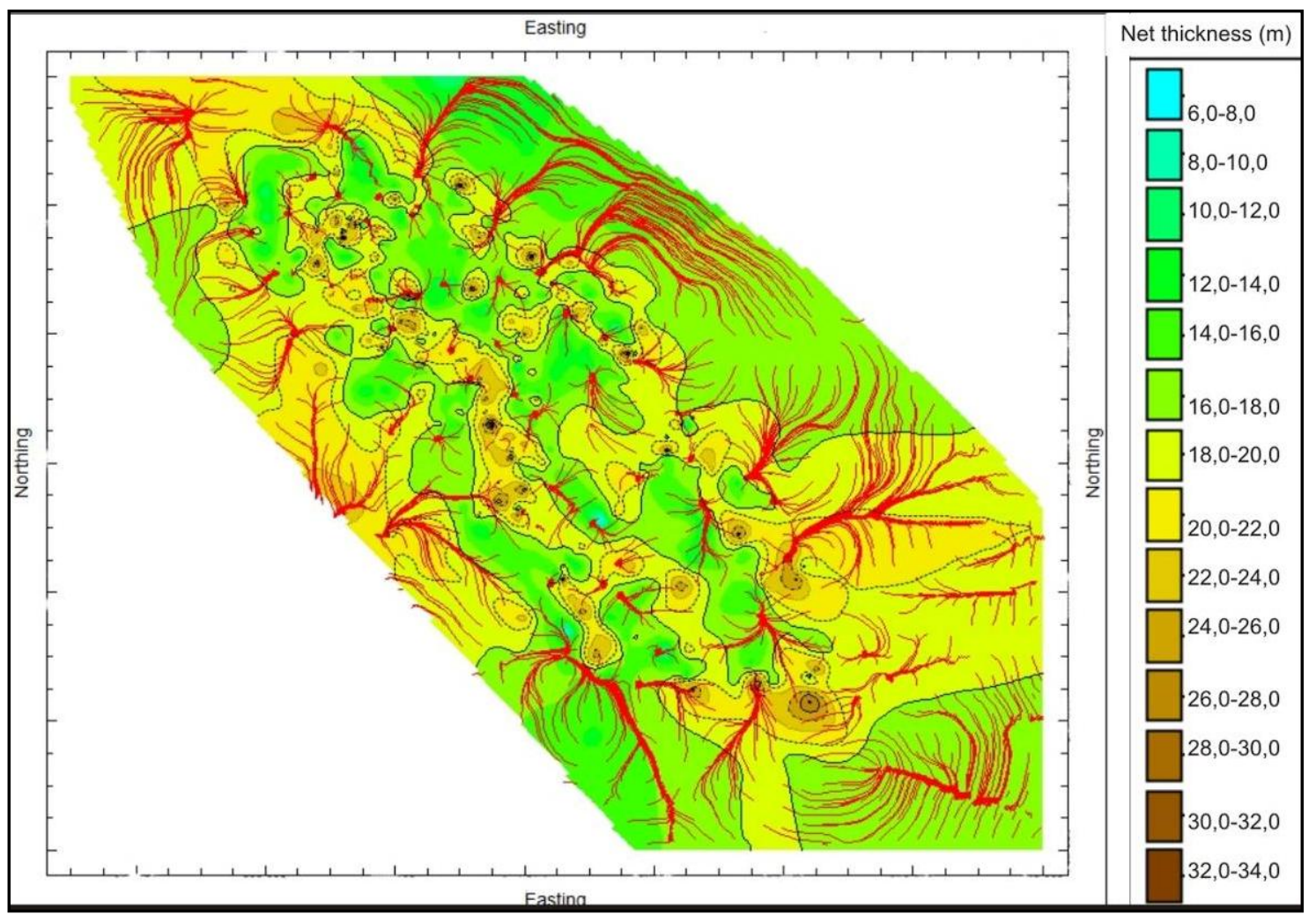

9-7. ábra Az áramlásos vektortérkép és az effektív homokvastagság kompozitja 


\section{0. Értékelés, diszkusszió}

A dolgozatban vizsgált, Szőreg-1 telepet harántoló fúrások rétegsorához kapcsolódó üledékes fácieseket hasonló felhalmozódási dinamika jellemzi. A fúráspontok mindegyike egy elosztó meder és mederáttörési, illetve ismétlődő vagy progradáló mederáttörések által lerakott üledékeket harántolt. A 2. és a 4.számú fúrásban az üledékképződést időszakos elgátolódások miatt mocsári környezet kialakulása szakította meg. Az 1. és a 3. számú fúrások környezetében az üledékképződés feltételei lehetővé tették egy természetes partgát és mederegyüttes kifejlődését, azonban a természetes partgát teljes kifejlődésének hiánya az üledékeket szállító áramlások változékony sebességéről, azok változó irányáról, és az üledék utánpótlás ingadozásáról tanúskodik. Míg az 1. számú fúrás esetében a meder - gát együttes üledékeit egy jól kifejlődött, mind térben és időben, mind az üledék utánpótlás mértékében stabilnak tünő elosztó meder homokja követi, addig a 3. számú fúrásban 3 mederáttörési ciklus üledékei települnek rá.

A maganyagok alapján elmondható, hogy a vizsgált területen a mederáttörési ciklusok még esetleg progradáló jellegük ellenére is - egyre gyengülő energiával mentek végbe. A fúrási rétegsorok és magminták alapján azonosított üledékfáciesek, illetve vertikális sorozatok a következők voltak:

1. TERMÉSZETES PARTGÁT - ELOSZTÓ MEDER - MEDERFELHAGYÁS MEDERÁTTÖRÉS átmenet

2. PROGRADÁLÓ MEDERÁTTÖRÉS - MOCSÁR átmenet

3. PROGRADÁLÓ MEDER - MEDERÁTTÖRÉSI LÓBA - PROGRADÁLÓ MEDERÁTTÖRÉS átmenet

4. MOCSÁR - HORDALÉKELOSZTÓ MEDER átmenet

Az egyes fúrások üledékfácieseinek térbeli kiterjesztését a VII-1 - VII-3. melléklet tartalmazza. Üledékes genetikai alapon tárolási szempontból legjobb kifejlődésü homokköveknek az 1. számú fúrás elosztó medrében lerakódott üledékeit tekinthetjük, míg legváltozatosabb felhalmozódási genetikával, legheterogénebb felépítéssel, és így tárolási szempontból legrosszabb tulajdonságokkal a 4. számú fúrás üledékei rendelkeznek

A korábban felállított fejlődéstörténetet - mely szerint a Szőreg-1 telepet az északról és délről progradáló torkolati zátonyok üledékeinek összefogazódása alakította ki - a dolgozatban ismertetett eredmények is megerősítik.

A dél-délnyugati torkolati zátony és meder-együttes maximális hossza 4,5-5 km. Homokos üledékei maximum 5 méter vastagságban követhetők nyomon. Ez a meder összekapcsolódik egy, a tetővonallal párhuzamos irányban kiépült másik mederrel a 
permeábilis tető alatti 22,5-23 méteres mélységben. A Déli torkolati zátony a GVH-t csak érinti a PT alatt 14 méteres mélységben, valamint a PT alatt 11-12,5 m mélységintervallumon belül, de a PT alatt 10-10,5 mélységek között a belöle kifejlődő keskeny elosztó meder a gázsapka területét a déli részen átszeli.

Az északi torkolati zátony maximális. szélessége: 1,5-1,8 km, maximális. hosszúsága 1,5 km. Üledékeinek vastagsága 4-5 méter. A GVH-t üledékei a PT alatt 7-9 méteres mélységintervallumok között metszik.

A korábbi modell pontosítása érdekében egy - az előzőekkel összefogazódó - keleti torkolati zátonyt is kimutattam, mely keletről nyugat-északnyugat irányba progradál, majd rajta kifejlődött elosztó medrek jelennek meg. Maximális hossza 4 km, maximális szélessége $3 \mathrm{~km}$. Üledékei maximum 5 méteres vastagságban követhetők nyomon. Ez a Keleti torkolati zátony a GVH-t a PT alatt 4-7,5 méter mélységintervallumban metszi.

A vizsgált területen az alábbi, jelentősebb mederalakulatokat különítettem el:

- „Meder-1”: DNy-ÉK-i irányultságú elosztómeder. A gáz-folyadék határt a PT alatt 6- 7,5 méter közötti mélységintervallumban metszi.

- „Meder-2”: É-ÉNy - D-DK-i csapásirányú, kezdetben kis, majd növekvő kiterjedésű meder, mely a PT alatt 14-15 méter között a gázsapka területére is mélyen benyúlik, és kisebb elosztómedrekkel szövevényes hálózatot alkot. Valószínűsíthető a PT alatt 14,5 méterrel a meder és a gázsapkától É-ÉK-i irányban található torkolati zátony közötti kapcsolat. A meder a gázsapka területéről É-i irányban kilépve feltöltődik. A gáz- folyadék határt a PT alatt 1219,5 méter mélységintervallumban metszi.

- „Meder-3”: egy D-DNy-i, kisebb méretű torkolati zátonyba bevágó, és É felé progradáló meder, melynek a gázsapka területén lévő magas homoktartalmú mederüledékekkel, illetve az onnan ÉNy felé, a gázsapka területéről kilépő mederalakulatokkal képzett kapcsolatát valószínüsítem. A PT alatt 26,5 -27 m mélységek között a meder még nem éri el a GVH-t, de valószínüsíthetjük egy ÉNy- i torkolati zátonyon kifejlődött, gázsapka felé tartó mederrel való későbbi összeolvadását.

A homoktesteknek kőzettesten belüli, lehetséges áramlásokat befolyásoló hatása tekintetében - figyelembe véve az üledékes fáciesek térbeli kiterjeszthetőségét és azok petrofizikai tulajdonságait - a peremi torkolati zátonyok üledékei képviselik a legnagyobb áramlási potenciált. A gáz- folyadék határt azonban a belölük kiinduló áramlások nem érintik, illetve a gázsapka felől esetlegesen a peremi irányba tartó áramlások nem lépnek ki a 
peremterületre. A gázsapka területén nagy számban előforduló mederáttörési lóbák áramlástanilag környezetüktől elszigeteltek, azonban összefogazódásuk folytán közöttük kisebb áramlások kialakulhatnak. Kockázati tényezőként az északi peremterületeken a torkolati zátonyokból kiinduló áramlási utaknak a gázsapka határához igen közeli pozícióját emelném ki. Ezeken a területeken a kitermelés és besajtolás folyamata során is fokozott monitoring és megfelelő óvatosság szükséges a kutak korai elvizesedésének megelőzése érdekében.

Szőreg-1 telep néhány fokos dőléssel társuló sajátos, ún. szendvics szerkezetének a ferde rétegződéssel alkotott analógiáját felhasználva a ferdén rétegzett magmintán felszívásos CT vizsgálat segítségével a kőzetben mikroléptékben diagnosztizálható folyamatok eredményét felskálázva következtettem a lehetséges makroléptékü folyamatokra. Megállapítottam, hogy a ferde rétegződésen belül a 2-6 \% effektív porozitású kőzetrészek inváziós folyosókként funkcionáltak, és ezeken keresztül indult meg legelőször a folyadék „ujjszerü áramlása” (idegen nyelvü szakirodalomban a fingering fogalmával azonosítható). A nagyobb effektív porozitású kőzetrészek csak az ezt követő töltődési fázisban kapcsolódtak be a feltöltés folyamatába. Legkésőbb a 22-28 \% porozitású kőzetrészekben indult meg az áramlás. Ezek alapján megállapíthatjuk, hogy a ferde rétegződés esetében a kiszorítás a nagyobb nyomáskontraszttal rendelkező kőzetekben hatékonyabban tud végbemenni, azaz nyomáskontraszt szempontjából heterogén kőzetben a kiszorítás, míg a homogén pórusnyomással jellemezhető kőzetrészekben a tárolás folyamata tud könnyebben érvényesülni. Mivel a gázsapka területe porozitás szempontjából igen heterogén, és a 22\%-os porozitáshoz tartozó izovonal a gázsapka pereméhez közel esik, így várhatóan a besajtolás és kitermelés során hasonló folyamatok mehetnek végbe a gázsapka területén belül is.

A Szőreg-1 telep már említett szerkezeti-genetikai tulajdonságai miatt a telep egyes medergenerációinak vertikális összefogazódása mikroléptékben az összeolvadási felszínnel mutat analógiát. Az összeolvadási felszín esetében a Laplace- operátorral készült statikus áramlási képek alapján megállapítható, hogy a vizsgált mintában az összeolvadási felszín a kis léptékü, vertikális irányú fluidum-áramlásokat kis mértékben befolyásolhatja, lassíthatja. $\mathrm{Az}$ összeolvadási felszín nem képez áramlási gátat, de kisebb gyüjtő területek kialakulását lehetővé téve lassíthatja a függőleges fluidum-áramlást, viszont mindezek ellenére megaléptékben mégis biztosítja a mederüledékek vertikális kommunikációját, így a mederüledékek összeolvadási felszíneken keresztül történő összefogazódása a vertikális irányú áramlásokat segíti.

A kőzettest tárolóként való működése, és a tárolóban zajló egyes folyamatok értékelésének, kockázati mérlegelésének szempontjából kulcsfontosságú a kőzetszöveti és 
kőzetfizikai tulajdonságok megítélése. Az ezen paramétereket célzó vizsgálatok eredményei azt mutatják, hogy a vizsgált minták porozitása elsődleges, felhalmozódási eredetü, ennek megfelelően az üledékes genetika a kőzetfizikai tulajdonságokban is tükröződik. Legnagyobb porozitással a progradáló mederáttörések üledékei rendelkeznek, ugyanakkor permeabilitásuk szórása is a legnagyobb. Szintén nagyon jó, és homogén porozitással jellemezhetőek az elosztó medrek. Ezt követik a mederáttörési lóbák homokkövei, majd a meder és természetes partgát komplexek, végül a legalacsonyabb permeabilitású, mederáttöréseket követő mederfelhagyások üledékei. Az üledékes genetika a szemcseméret eloszlásokban is nyomon követhetö.

A higanyos mérések eredményei alapján megállapítható, hogy a vizsgált minták pórusterét elsődlegesen szedimentációs hatások határozták meg. A másodlagos, pórusteret érintő hatások a vizsgált mintákban csak alárendelten vannak jelen, viszont kőzetfizikai tulajdonságokra - és ezen keresztül a tároló müködésére, a tárolóban lejátszódó transzportfolyamatokra - gyakorolt hatásuk a gyakorlatban mégsem elhanyagolható. A másodlagos hatások által legkevésbé érintett 7,5-15 mikron közé eső pórusok tartománya. A diagenezis pórusteret érintő hatásával kapcsolatos megállapításokat a SEM felvételek is alátámasztják. Azt a tényt, hogy a kőzetszövetet és a petrofizikai tulajdonságokat döntően az üledék osztályozódását elősegítő szedimentáció, a hirtelen kiülepedés és az eróziós folyamatok alakították ki, a faktor analízis eredményei is megerősítik. A másodlagos diagenetikus eredetü hatások - mint például a karbonát ásványok hatása - valóban csak kis mértékben vannak jelen, ettöl függetlenül a kalcit és a dolomit tartalom a homokkövekben a porozitást és a permeabilitást is rontja. A karbonát tartalom növekedése a 2,5- 5 mikron közötti pórusméret tartományt a 0,1-0,235 mikronos pórusok javára szükíti, amit a porozitás és permeabilitás javítását célzó kútmunkálatok során javasolt figyelembe venni. 


\section{Köszönetnyilvánítás}

Jelen disszertáció részben a MOL Nyrt és az SZTE Földtani és Őslénytani Tanszéke között létrejött „FGT fejlesztések: kőzetmechanika, modellezés, felszíni technológia” című kutatás-fejlesztési projekten belül a „Szőreg-1 telep szedimentológiai revíziója” tárgyban készült kutatómunka eredményeit használja fel (projektszám: UX7317.10.45/95). Mindenek elött szeretném kifejezni köszönetemet a SZTE Földtani és Öslénytani Tanszékének,hogy tagja lehettem a tanszéken müködő Geostatisztikai-Geomatematikai Kutatócsoportnak, és ezáltal betekintést nyerhettem a tudományos munkák és eredmények ipari gyakorlatban történő hasznosulásának folyamatába, mely nagymértékben hozzájárult tudományos szemléletmódom formálásához.

Hálával tartozom témavezetőmnek, Dr. Geiger Jánosnak, hogy sok évvel ezelőtt, mikor ismeretlenül, tudásra szomjazva bekopogtam az irodájába, nem küldött el, hanem végighallgatta szedimentológiával kapcsolatos terveimet. Köszönöm, hogy mindvégig hitt bennem, hogy nélkülözhetetlen segítségként mindig tudása legjavát adta - nem csak nekem -, és mind szakmai, mind emberi megnyilvánulásaival rávezetett a kutatómunka szeretetére, elindított és segített a tudományos pályán. Köszönöm, hogy hagyta, hogy megtapasztaljam, hogy minden hegyre ezer út vezet föl, de nem mindegyik egyforma hosszú.

Köszönöm Dr. Sümegi Pál tanszékvezetőnek, hogy lehetőséget biztosított arra, hogy munkámat a Földtani és Öslénytani Tanszéken végezhessem.

Köszönet illeti Dr. Hunyadfalvi Zoltánt, amiért a CT-vel kapcsolatos elözetes tapasztalatait, ismereteit megosztotta velem, és partnerként kezelt a gyakran felmerülő technikai problémák megoldásában.

Köszönöm Földes Tamásnak, Tokai Richárdnak, és a Kaposvári Egyetem Diagnosztikai és Onkoradiológiai Intézetének, név szerint Dr. Bogner Péternek, hogy lehetővé tették a szükséges CT- mérések elvégzését.

Hálával tartozom a tanszék „péhádésainak”, név szerint Horváth Janinának, Hupuczi Júliának, Imre Mariannának, Mészárosné Herbich Katalinnak, Náfrádi Katalinnak, Páll Dávidnak, Persaits Gergőnek, hogy a doktori évei alatt biztosították a tanszéken a kellemes, baráti légkört, és hogy a „kutatói lét” átlagos, boldog vagy kínkeserves pillanataiban is osztoztak velem.

Külön köszönöm Katusnak, hogy általa betekintést nyerhettem közös munkánk alkalmával az östölgyek rejtett titkaiba, de ennél fontosabb, hogy köszönöm az együtt töltött szakmai utak, és a megoldhatatlannak tünő szakmai rejtélyek oknyomozásának felejthetetlen - és sokszor eredményes - pillanatait, valamint hitét, optimizmusát és támogatását. 
Szintén köszönöm Janának, hogy számomra teljesen új világok kapuit nyitotta fel előttem, és hálás vagyok, hogy ilyen sokat tanulhattam tőle: kitartást, módszerességet, egy új látásmódot, amit saját területemen is kamatoztathattam.

Köszönöm Gulyás Sándor kollégámnak, hogy bármikor fordulhattam hozzá a felmerülő kérdéseimmel, és készségesen próbált velem együtt megoldást találni.

Köszönöm Barkóczi Zoltánné Katikának az évek során felmerülö adminisztratív ügyekben nyújtott segítségét és az emlékezetes eszmecseréket az élet nagy kérdéseiről, mert a tudomány nem minden.

Köszönöm Dr. Szentgyörgyi Károlynak, hogy tanácsaival, értékes észrevételeivel segítette munkámat.

Szeretnék köszönetet mondani azoknak a kollégáknak és barátoknak, akik akár munkához való hozzáállásukkal, akár pálya és/vagy munkahely iránti elkötelezettségükkel, néhány hozzám intézett szakmai kérdésükkel, vagy a velem folytatott szakmai, vagy baráti beszélgetésükkel - talán tudtukon kívül is - hozzájárultak ahhoz, hogy újult erővel folytassam a megkezdett munkát. Név szerint Kalocsai Péternek, Kiss Balázsnak, Kissné Veress Katalinnak, Kovács-Vad Bernadettnek, és Kovács Ferencnek.

Köszönöm egykori Hallgatóimnak a tananyaggal kapcsolatos, de számomra gondolatébresztő erejü kérdéseket, melyek olykor előbbre vitték saját kutatásomat.

Hálával tartozom Szüleimnek, hogy hosszú éveken át megteremtették a tanulásomhoz szükséges feltételeket, és mindvégig türelemmel, szeretettel támogattak az elképzeléseimben.

Nem utolsó sorban köszönöm Férjemnek, Attilának, hogy végigolvastatta velem saját disszertációját, mert így már tudom, hogy én mit fogok másképp csinálni. Köszönöm tanácsait, türelmét, kitartó biztatását, és hogy velem együtt virrasztott a szövegszerkesztéssel töltött éjszakákon...

Disszertációmat Családomnak ajánlom. 


\section{IRODALOMJEGYZÉK}

Anderson, B. - Helbig, K. (1994): Oilfield anisotropy: Its origins and electrical characteristics, Oilfield Review, 1994 October, pp. 48- 56.

Ayan, C., - Colley N. - Cowan, G. - Ezekwe E. - Goode P. - Halford F. - Joseph J. Mongini A. - ОвоndoKo G. - Pop J.(1994): Measuring permeability anisotropy: The latest approach, Oilfield Review, 1994 October, pp 24- 26.

BALOGH K. - MolnÁR B. (1972): Üledéktani gyakorlat, JATE Press, Szeged, 1p

BARTA F. (1959): Finomrétegtani vizsgálatok a Balaton-környéki felső-pannon képződményeken. A Magyar Állami Földtani Intézet Évkönyve 48.,1191.

BÉRCZI I. - PHILliPS R. L. (1985): Processes and depositional environments within Neogene deltaic- lacustrine sediments, Pannonian Basin, Southeastern Hungary, Geophysical Transactions, 31, pp 71-87. Budapest

BÉRCZI I. (1988): Preliminary sedimentological investigation of a neogene depression in the Great Hungarian Plain, in: The Pannonian Basin: A study in basin evolution, AAPG Memoir, Royden L. H. and Horváth F. eds. pp 107-116.

BÉRCZI I. - HÁMOR G. - JÁMBOR Á. - SZENTGYÖRGYI K.(1988): Neogene sedimentation in Hungary, in: The Pannonian Basin: A study in basin evolution, AAPG Memoir, Royden L. H. and Horváth F. eds. pp 57-68.

Boespflug, X. - Long, B. - OCChiETTI, S. (1995). CAT-scan in marine stratigraphy: a quantitative approach. Marine Geology 122, pp. 281-301.

BöcK J. (1875): A Bakony déli részének földtani viszonyai, Magyar Állami Földtani Intézet Évkönyve 3.

Elliott, T. (1986): Deltas, In H. G. Reading (ed): Sedimentary Environments and Facies, 2nd Ed. Blackwell, Oxford, 1986.

Földes, T. - Kiss, B. - ÁrgyelÁN G. - Bogner, P. - REPA, I., (2000): Application of medical computer tomograph measurements in $3 \mathrm{D}$ reservoir characterisation. EAGE SAID Conference, Paris, France

Fuchs T. (1870): Die Fauna der Congerienschichten von Tihany am Plattensee und Kup bei Pápa in Ungarn. Jahrbuch d.k.k.Geol.Reichsanst..20.

Fuchs T. (1870): Die Fauna der Congerienschichten von Radmanesti im Banate. Jahrbuch d.k.k. Geol. Reichsanst.343.

Gajdos I. - PAPP S. - Somfai A. - VölgYi L. (1983): Az alföldi pannóniai (s. 1.) képződmények litosztratigráfiai egységei. Budapest, A Magyar Állami Földtani Intézet kiadványa 148. 
GEIGER J.(1988): Delta progradációs nagyciklusok az alföldi pannóniai (s.l) medence feltöltődésében az üledékes kőzettest.morfológiai vizsgálatok alapján, Földtani Közlöny, 118. pp. 219-238.

GEIGER J. ( 2002): A pannóniai Újfalui (Törteli) formációban lévő Algyő delta fejlődéstörténete I.: Az Algyö-delta alkörnyezeteinek 3D modellezése, Földtani Közlöny, 133/1, pp. 91-112.

GEIGER J. ( 2004): A pannóniai Újfalui (Törteli) formációban lévő Algyő delta fejlődéstörténete II.: Az Algyő-delta deltasíkjának üledékszerkezeti jegyei, Földtani Közlöny, 134/1. pp. 55-73.

Geiger, J - Hunyadfalvi, Z - Bogner, P (2009): Analysis of small-scale heterogeneity in clastic rocks by using computerized X-ray tomography (CT), Engineering Geology 2009, vol. 103. No. 3-4. pp. 112-118.

Geiger J. - KisSNÉ Veres K. - KoMLósi J.(1998): A Szőreg-1 telep 3D rezervoár geológiai modellje, KUMMI Jelentés, p.216

GEIGER J - KomLÓSI J. (1996) : Szedimentológiai, geomatematikai 3D modellező rendszer törmelékes CH tárolókban, Köolaj és Földgáz 2., pp. 53- 81.

GEIGER J. - SEBŐK Sz. (2008): A Szőreg-1 telep gázsapka maradványának geológiai elemzése, I. MOL Jelentés

GEIGER J. - SEBÖK Sz.(2008): A Szőreg-1 gázsapkára fúrt magok komplex üledékföldtani vizsgálata. II. MOL Jelentés

GEIGER J. - SEBŐK Sz (2009). : A szőreg-1 telep maradék gázsapkájának szedimentológiai jellemzése $A 3$ éves projekt zárójelentése - I.-II. kötet

HALAVÁTS Gy. (1882): Öslénytani adatok Délmagyarország neogén korú üledékei faunájának ismeretéhez. A langenfeldi pontusi korú fauna. M.kir. Földtani Intézet Évkönyve 6.

HALAVÁTS GY (1886): Őslénytani adatok délmagyarországi neogén korú üledékek faunájának ismeretéhez. A kustélyi pontusi korú fauna. A nikolczi pontusi korú fauna. A csukicsi pontusi korú fauna. M.kir. Földtani Intézet Évkönyve 8.

HALAVÁTS GY (1892): Őslénytani adatok délmagyarországi neogén korú üledékek faunájának ismeretéhez. A királyhegyi pontusi korú fauna. M.kir. Földtani Intézet Évkönyve 10.

HaLAVÁTs Gy (1911): A balatonmelléki pontusi korú rétegek faunája, A Balaton Tudományos Tanulmányozásának Eredményei, Pal. Függelék IV/2.

HalavÁts Gy (1923): A baltavári felsőpontusi korú molluszkafauna. M.kir. Földtani Intézet Évkönyve 14. 
Horváth F. (1995) Phases of compression during the evolution of the Pannonian Basin and its bearing on hydrocarbon exploration, Marine and Petroleum Geology, Vol.12. Issue 8. pp. 837- 844 .

HÖRNES M (1862-1870): Die Fossilis Molluscen der Tertierbecken von Wien. Abh.d.k.k.Geol.Reichsanst. Wien.R.III-IV.

Hunt, P.K. - Eugier, P. - BAJSAROwiCZ, C., (1988). Computed tomography as a core analysis tool: applications, instrument evaluation, and image improvement techniques. Soc. Pet. Eng. pp. 1203-1210.

HUNYADFALVI Z. (2004): Heterogeneity analysis of clastic sediments by computerized X-ray tomographs, Acta Geologica Hungarica, Vol.47/1, pp.53-62.

HunYADFALVI Z, (2006): Kisléptékü heterogenitás vizsgálatok törmelékes üledékekben röntgen computer tomográf segítségével. Doktori (PhD) értekezés, SZTE Földtani és Öslénytani Tanszék

JUHÁSZ GY. (1992): A pannóniai s.l. formációk térképezése az Alföldön: elterjedés, fácies és üledékes környezetek - Pannonian s.l. formations in the Hungarian Plain: distribution, facies and sedimentary environment. - Földtani Közlöny, 122. 2-4., pp. 133-165.

JUHÁSZ GY. (1994): Magyarországi neogén medencerészek pannóniai s.l. üledéksorának összehasonlító elemzése. (Comparison of the sedimentary sequences in Late Neogene subbasins in the Pannonian Basin, Hungary) - Földtani Közlöny 124/4, pp. 341-365. Budapest

JuHÁSz GY. - MAGYAR I (1992): A pannóniai (s.1) litofáciesek és molluszka biofáciesek jellemzése és korrelációja az Alföldön, Földtani Közlöny, 122/2-4, pp. 167-194.

Koltermann, C. E. - Gorelick, S. M. (1996): Heterogeneity in sedimentary deposits: Areview of structure- imitating, process- imitating, and descriptive approaches, Water Resources Research, Vol. 32, No. 9, Sept. 1996, pp 2617- 2658.

KoRPÁS-HóDI M.(1983): A Dunántúli középhegység északi előtere pannóniai Mollusca faunájának paleoökológiai és biosztratigráfiai vizsgálata. Palaeoecology and biostratigraphy of the Pannonian Mollusca fauna in the northern foreland of the Transdanubian Central Range, A Magyar Állami Földtani Intézet Évkönyve 66.1, pp.1-163,

LEWIS, J. J. M. (1988): Outcrop- derived quantitative models of permeability heterogeneity for genetically different sand bodies, SPE Paper, 63rd Annual Technical Conference and Exhibition of hte Society of Petroleum Engineers, Houston, Texas, Oct 2-5, 1988, pp.449- 463. 
LóCZY L. (1913): A Balaton környékének képződményei és ezeknek vidékek szerinti telepedése. A Balaton Tudományos Tanulmányozásának Eredményei, Budapest

MAGYAR I. (2004): Tanulságok a hazai pannóniai puhatestü- rétegtan történetéből-What lessons can we learn from the hundred-year history of Lake Pannon mollusc biostratigraphy in Hungary, Földtani Közlöny,2004, 134/3, pp. 369-390.

MATTERn, F. (2002): Amalgamation surfaces, bed thickness, and dish structures in sand rich submarine fans:numeric differences in channelized and unchannelized deposits and their diagnostic value, Sedimentary Geology 150 (2002) 203-228,

Mattick, R. E - Rumpler J. - Phillips R. L. (1985): Seismic stratigraphy of the Pannonian Basin in Southeastern Hungary, Geophisical Transactions v. 31. 1-3. Special Edition, Budapest, pp.13-55

MÁFI (1997): Magyarország litosztratigráfiai alapegységei, MÁFI-MRB, (Császár G. szerk.)

MEYER, R. (2002): Anisotropy of sandstone permeability, CREWES Research Report, Volume 14.(2002)

MeYer, R. - Krause F. (2006): Permeability anisotropy and heterogeneity of a sandstone reservoir of a sandstone reservoir analogue: An estuarine to shoreface depositional system int he Virgelle Member, Milk River Formation, Writing- on- Stone Provincial Park, Southern Alberta, Bulletin of Canadian Petroleum Geology, Vol. 54.No.4. (Dec. 2006) pp. 301- 318.

MMBF (2008): A Szőreg-1 földalatti gáztároló felszín feletti berendezései, http://www.mmbf.hu/hu/cegismerteto/tarolo_leirasa/

Mucsi M. (1973): A Dél- Alföld földtani fejlödéstörténete a neogénben, Földtani Közlöny 103, pp.311-318,

MUCSI M. - RÉVÉSZ I. (1975): Neogene evolution of the southeastern part of the Great Hungarian Plain on the basis of sedimentological investigations, Acta Mineralogica_ Petrographica, 22, pp. 29-49, Szeged

Nagy Gy. - Benedek L. - PiPicz V. - PAPP I. - Ósvay Hnisz M., - Tóth VARga I. - Geiger J.(2008): Gas supply security or enhanced gas recovery? With adeqate reservoir management- No need to choose!, MOL Scientific Magazine Development, 2008/3., pp.51-52.

PARTSCH P. (1835): Über die sogenannten versteinerten Ziegenklauen aus dem Plattensee in Ungarn, und ein neues, urweltliches Geschlecht zweischaliger Conchylien. - Ann. Wiener Mus. Natur. 1, pp. 95-102

PogÁCsÁs, Gy. (1984): Results of seismic stratigraphy in Hungary, Acta Geologica Hungarica 27/1.2, pp. 91-108. 
PogÁcsÁs Gy. - JÁmbor Á. - MATtick R. E. - Elston P. - HÁmor T. - LAKATOS L. Lantos M. - Simon E. - Vakarcs G. - VÁrkonyi L. - VÁrnai P. (1989): A nagyalföldi neogén képződmények kronosztratigráfiai viszonyai szeizmikus és paleomágneses adatok összevetése alapján. Magyar Geofizika, 30/ 2-3. pp. 41- 62.

PogÁCsÁs Gy. - SzABÓ A. - SzAlay J. (1992): Az alföldi progradációs delta sorozatok kronosztratigráfiai viszonyai, Magyar Geofizika,33/1. pp 1-13.

Postma, G. (1990): Depositional architecture and facies of river and fan deltas: a synthesis, Spec Publs int. Ass. Sediment 10, pp. 13-27.

RÉVÉSZ I (1980): Az Algyő-2 telep földtani felépítése, üledékföldtani heterogenitása és ősföldrajzi viszonyai. Földtani közlöny, 1980. (110. évf.), 3-4. sz., 512-539. p.

RICCI LUCCHI, F. (1995), Sedimentographyca, a Photographic Atlas of Sedimentary Stuctures, -Second Edition, New York, Columbia University Press,. 105 p

Ringrose P. - Pickup, G. - Jenssen, J. - Forrester, M.(1999): The Ardross Reservoir gridblock analog: Sedimentology, statistical representivity and flow upscaling, 1999, in: R. Schatzinger and J. Jordan, eds, Reservoir Characterisation- Recent Advances, AAPG Memoir 71. pp 265- 276.

RINGROSE, P. - NORDAHL K. - WEN, J. - (2005):Vertical estimation in heterolithic tidal deltaic sandstones, Petroleum Geoscience, Vol. 11. 2005, pp. 29- 36.

Royden L. - Horváth F. - Nagymarosy A. - Stegena L. (1983): Evolution of the Pannonian Basin System: 2. Subsidence and thermal history, Tectonics, Vol.2, No. 1. pp 91- 137.

SEBÖK Sz. (2006): Analyses of small scale texture feature of amalgamation- and erosional surfaces by computerized X-ray tomography, X.Geomatematikai Ankét: Geomatematika, geostatisztika, térinformatika és távérzékelés alkalmazásai a környezet és földtudományokban, Mórahalom, 2006. május.

SEBÖK Sz. (2008): Modelling of Small Scale Fluid Flows by Core Samples Measured by CT, XII. Congress of Hungarian Geomathematics and the First Congress of Croatian and Hungarian Geomathematics, Mórahalom, 29-31. May, 2008. Internetes publikáció

SEBÖK Sz. (2008): Numerikus módszerek az összeolvadási felszín szöveti tulajdonságainak CT- vizsgálatában, Földtani Közlöny, Budapest,2008, 138/4, pp 401-410.

SELLEY, R. C.(1996): Ancient sedimentary environments and their sub- surface diagnosis, Fourth Edition, pp. 14- 16., Chapman\& Hall, 1996

Stevanovic P. M. (1951): Pontische Stufe im engeren Sinne, Obere Congerienschichten Serbiens und der angrenzenden Gebiete.

Strausz L. (1971): A Pannóniai emelet (pliocén), Földtani Közlöny, 71., 220-237, Budapest 
STRAuSz L. (1949): A Dunántúl délnyugati részének kavicsképződményei. Földtani Közlöny, 1-63. Budapest.

SÜMEGHY J. (1939): A győri medence, a Dunántúl és az Alföld pannóniai üledékeinek összefoglaló ismertetése. M.kir. Földtani Intézet Évkönyve 32.

SZALAY A. - SzENTGYÖRGYI K. (1988): A Method for Lithogenetic Subdivision of Pannonian (s. 1.) Sedimentary Rocks: Chapter 8, Volume M 45: The Pannonian Basin: A Study in Basin Evolution, Pages 89 - 96

SzÉLES M.(1968): Az Alföld déli részének pliocén képződményei, Földtani Közlöny, 98. pp. 55-66.

SzÉLES M.(1971): A Nagyalföld medencebeli pannon képződményei In: A magyarországi pannonkori képződmények kutatásai, Góczán F.-Benkő J. (szerk.), Budapest, 1971, pp. 253-344.

TELEGDi RóTH K. (1879) : Umgebung von Kismarton (Eisenstadt). Geologische Skizze der Kroisbach- Ruster Bergzuges und Südlichen Teiles des Leitha Gebirges, Földtani Közlöny, v. 9. p. 23- 45.

TöRnQvist, T. E. (1993): Crevasse splay of the Mississippi River http://www.geo.uu.nl/fg/palaeogeography/results/fluvialstyle:

VAKARCS G. (1997): Sequence stratigraphy of the cenozoic pannonian basin, Hungary, Thesis, Rice University, Houston, Texas, pp. 86.

VAKarcs G. - Hardenbol J. - Abreu V.S. (1998) : Oligocene - middle miocene depositional sequences of the central paratethys and their correlation with regional stages, Mesozoic and Cenozoic Sequence Stratigraphy of european Basins, SEPM Special Publication No. 60. pp 209- 231.

WEN, R. (2006): Multi-scale heterogeneity modelling: A method for reservoir data integration, EAGE 68th Conference \& Exhibition - Vienna, Austria, 12 - 15 June 2006

WiLlis, B. J. - WHITE, C. D. (2000): Quantitative outcrop data for flow simulation, Journal of Sedimentary Research, Vol. 70., No. 4. July 2000, pp. 788- 882.

ZATZ, L. M., (1981), Basic principles of computed tomography scanning, In: Newton, T. H, Potts, D. G ( Eds), Technical Aspects of computed tomography. Soil Science Cociety of America Journal 60, pp 1718- 1724. 


\section{Magyar nyelvü összefoglaló}

Dolgozatomban a Szőreg-1 telep gázsapkát tartalmazó teleprészének részletes geológiai vizsgálatával pontosítottam a telep felhalmozódására vonatkozó korábbi modellt. A kutatómunka alapját a stratégiai tároló kialakítása kapcsán a Szegedi Tudományegyetem Földtani és Öslénytani Tanszékén 2006-2009 között futó- UX7317.10.45/95 számú- K+F projekt keretén belül részben általam elvégzett adatfeldolgozás és elemzés (GEIGER J.- SEBÖK Sz., 2008,2009), valamint a témához kapcsolódó, korábbi saját vizsgálati eredményeim (SEBÖK SZ. 2006,2008) jelentették. Korábban diplomamunkámat pannóniai mélyfúrási magminták üledékszerkezeti jegyeinek leírásából, kőzetszöveti tulajdonságainak CTvizsgálatából írtam, melyben a további kutatásra irányuló célkitüzéseimet doktori munkámba beépítve igyekeztem megvalósítani. A vizsgálatok a szedimentológiában ismert 3 léptékben mikro-, makro-, és megaléptékben - történtek.

A dolgozatban tárgyalt vizsgálatokhoz 4 fúrás magmintáit, és azok magvizsgálati adatait használtam fel. A mélyfúrási magminták litológiai leírását követően egy részletes szedimentológiai, genetikai alapú rétegsor felállítása, az üledékszerkezeti jegyek tanulmányozása nyújtott alapot az üledékfáciesek definiálásához. Megállapítottam, hogy a fúrások hasonló felhalmozódási dinamikával rendelkeznek. Mindegyikük egy elosztó medermederáttörési lóba illetve ismétlődő vagy progradáló mederáttörések által lerakott üledékeit harántolta. A mederáttörési ciklusok még esetlegesen progradáló jellegük ellenére is fokozatosan gyengülő energiával mentek végbe. A korábbi fejlődéstörténeti modellt, mely szerint a telepet az északról és délről progradáló torkolati zátonyok üledékeink összefogazódása alakította ki, a dolgozatban ismertetett eredmények is megerősítik. A korábbi modell pontosításának érdekében egy, az előzőekkel összefogazódó, 4 km hosszú, maximum $3 \mathrm{~km}$ széles Keleti torkolati zátonyt is kimutattam, melynek üledékei 3 méter vastagságban követhetők nyomon. A vizsgált területen 3 jelentősebb mederalakulatot különítettem el.

A Szőreg-1 telep kis dőlésszöggel jellemezhető sajátos ún. „szendvics- szerkezete”, és az üledékes genetika ismeretében az üledékszerkezeti jegyek közül a ferde rétegződést, és az összeolvadási felszínt felskálázva és analógiaként használva azokat CT segítségével mikroléptékü szöveti heterogenitásvizsgálatnak vetettem alá. Ferde rétegződésủ magmintán egyfázisú fluidum-áramlási vizsgálatot végeztem a megaléptékben a tárolóra jellemző genetikából eredő - t.i. az egyes medergenerációk, elosztómedrek vertikális összeolvadása belső heterogenitás kőzettesten belüli áramlásokra gyakorolt lehetséges hatásának vizsgálatára. Megállapítottam, hogy a ferde rétegződésen belül legkésőbb a 22-28 \% 
porozitású kőzetrészekben indult meg az áramlás, valamint a kiszorítás a nagyobb nyomáskontraszttal rendelkező kőzetekben hatékonyabban tud végbemenni. Ez gyakorlati oldalról azt jelenti, hogy nyomáskontraszt szempontjából heterogén kőzetben a kiszorítás, míg a homogén pórusnyomással jellemezhető kőzetrészekben a tárolás folyamata tud könnyebben érvényesülni. Mivel a gázsapka területe porozitás szempontjából igen heterogén, és a 22\%-os porozitáshoz tartozó izovonal a gázsapka pereméhez közel esik, így várhatóan a besajtolás és kitermelés során hasonló folyamatok mehetnek végbe a gázsapka területén belül is. Az összeolvadási felszín esetében a Laplace- operátorral készült statikus áramlási képek alapján megállapítottam, hogy a vizsgált mintában az összeolvadási felszín a kis léptékü, vertikális irányú fluidum-áramlásokat kis mértékben befolyásolhatja, lassíthatja. Nem képez áramlási gátat, de kisebb gyüjtő területek kialakulását lehetővé téve lassíthatja a függőleges fluidumáramlást, azonban megaléptékben mégis biztosítja a mederüledékek vertikális kommunikációját, így a mederüledékek összeolvadási felszíneken keresztül történő összefogazódása a vertikális irányú áramlásokat segíti.

A makroléptékü vizsgálatok szintjén megvizsgáltam a kőzetfizikai tulajdonságok térbeli heterogenitását, és kapcsolatukat az egyes üledékképződési környezetekkel, üledékes fáciesekkel. A kapott eredmények alapján megállapítottam, hogy kőzetfizikai tulajdonságok alapján legjobb kifejlődéssel a progradáló mederáttörések, és az elosztó medrek üledékei rendelkeznek. A pórustér elsődlegesen szedimentációs eredetű, így másodlagos hatások, mint például a karbonát-tartalom növekedésének hatása a 2,5-5 mikron közé eső pórustartományt érinti oly módon, hogy azt beszükítve a mikropórusok arányát növeli. Ezt a tulajdonságot a permeabilitás javítására irányuló kútmunkálatok során javasolt figyelembe venni.

A megaléptékű vizsgálatok szintjén részletesen elemeztem a telepet felépítő homoktestek helyzetét, térbeli kifejlődését, a mederalakulatok, és tárolási-termelési, fluidumáramlási viszonyok szempontjából kiemelt fontosságú nagyobb homoktesteket, és azoknak a gáz- folyadék határhoz viszonyított helyzetét. A vizsgálatokat összegezve megvizsgáltam a gázsapka peremterületén lehetséges áramlásviszonyokat. Áramlások szempontjából legnagyobb áramlási potenciállal rendelkező tárolórészként a peremi torkolati zátonyok üledékeit jelöltem meg. A gáz- folyadék határt azonban a belölük kiinduló áramlások nem érintik, illetve a gázsapka felől esetlegesen a peremi irányba tartó áramlások nem lépnek ki a peremterületre. A gázsapka területén nagy számban előforduló mederáttörési lóbák áramlástanilag környezetüktől elszigeteltek, azonban összefogazódásuk folytán közöttük kisebb áramlások kialakulhatnak. Kockázati tényezőként az északi peremterületeken a torkolati zátonyokból kiinduló áramlási utaknak a gázsapka határához igen közeli pozícióját neveztem meg. 
A több léptéket felölelő vizsgálatok eredményeit gyakorisági hisztogramok, faktor analízisek, box-plotok, homoktartalom metszeti térképek és más grid-alapú térképek, autokorrelogramok és vektoros gridtérképek, valamint magfotók alapján mutattam be.

A dolgozatban közölt új eredmények a korábbi modell pontosításához, a tárolóban zajló folyamatok pontosabb megértéséhez, egyes kútmunkálatok pontosabb megtervezéséhez, a stratégiai tároló biztonságosabb müködtetésének előretervezéséhez, esetleges problémamegoldásokhoz, későbbi fúráspontok kijelöléséhez nyújthatnak segítséget. A ferde rétegződésű mintán végzett egyfázisú, nyomás alatti felszívásos CT- mérés adatainak elemzése kiterjeszthető lenne hasonló környezetben, több fázissal történő vizsgálatokra, mely a tárolóban zajló tényleges, több fázis jelenlétében zajló folyamatok megértését segíthetné elő. 


\section{Summary}

The thesis summarizes the results of the clarification of a former depositional model of Szöreg-1 gas cap. The theoretical background is based on a Research\&Development project between 2006 and 2009 ran by the involvement of the University of Szeged, Department of Geology and Archaeology and the MOL Hungarian Oil and Gas Plc. related to designing the strategic gas storage. The thesis summarizes the results of the data processing and analysis done partly by the author within this project, and also the author's previous results connected to this topic. The diploma work of the author is also connected to sedimentological analysis and CT surveys on Pannonian core plugs, thus the objectives of its further researches were incorporated to this doctoral thesis.

As usual in the practice of classical sedimentology, the surveys took place in micro-, macro- and mega scale. Applying a detailed geological- sedimentological survey based on core descriptions and stratigraphical-lithological logs in addition to a thorough ascertainment of sedimentological environments and facieses, textural features and CT-data a more sophisticated model can be established.

During the analysis the core descriptions and core plug- survey data of 4 wells of the research area are examined. Following a lithological description of the cores, a detailed sedimentological and genetic- based stratigraphical log was set up complementary with sedimentary structures. It gave an effective base to define the sedimentary facies. The 4 wells have very similar depositional dynamics. All of them deepened into the sediments of a distributary channel- crevasse splay or prograding crevasse splay transition. Despite the prograding nature, the crevassing cycles showed a gradually weakening energy-unit.

According to the former genetic model of Szőreg-1, the sediments of the gas cap were deposited by the merging sediments of distributary mouth bars prograding from the north and from the south. This model can be confirmed by the results published in this thesis. However, the presence of a third, $4 \mathrm{~km}$ long and $3 \mathrm{~km}$ wide distributary mouth bar was also attested prograding from the east. Besides three bigger distributary channels were also delineated.

The Szőreg-1 reservoir is a unique, gently dipping, so called „sandwich- type” reservoir. Due to certain theoretical concepts, it is assumed that in micro scale by using the cross bedding and the amalgamation surface as analogues to this inner structure, it is possible to examine the effect of these bedding structures on potential fluid flows. Applying a monophase imbibition CT-measuring method, the effect of inner textural heterogeneity of rocks on monophase fluid flow can be followed and mapped. It is demonstrated, that in a cross bedded rock the fluid flow started latest in the parts of the rock with $22-28 \%$ porosity, and the 
displacement process was more effective in the rock parts with bigger internal pore pressurecontrast. Thus, it was pointed out, that the displacement is more effective in rocks which are heterogeneous in the sense of pressure contrast. Meanwhile the drainage is more effective in rocks which are homogenous in the sense of pore pressure. The latter one is better for storage. Hence the body of the gas cap is rather heterogeneous, and the $22 \%$ porosity isocontour is very close to the edge of gas cap, very similar processes may occur during the injection and production.

As regards the amalgamation surface a static flow-map was carried out by Laplacian operator. It was pointed out that the amalgamation surface does not act as a flow barrier. However, it can create smaller collector patches, which can slow the fluid flows in vertical direction. Even so, in mega scale it can ensure the vertical communication of channel sediments. Thus merging of channel sediments with amalgamation surfaces can enhance vertical fluid flows. With scaling up these results, it can be useful to get to know the behaviour of a sandwich type reservoir regarding fluid flows.

At a macro scale the spatial heterogeneity of petrophysical properties in terms of sedimentary environments and facieses were also investigated. On the basis of results as a best developed reservoir rock the sediments of prograding crevasse splays and distributary channels were named. It is also proven and supported numerically in addition with SEM examination that the pore space is primarily of sedimentary origin. Thus, secondary effects e.g. the effect of growth of carbonate content was related to the pores between 2,5 and 5 microns in such a way, that by the narrowing these pore interval, the ratio of micro-pores raised. This feature should be taken into consideration while planning workovers for enhancing permeability of the reservoir rock.

At a mega scale a detailed examination of spatial location and development of sand bodies correlated to the OWC, considering those bigger ones which could have an effect on storage or production processes - e.g. distributary mouth bars, channel deposits and crevasse splay deposits - was carried out. Summarizing the results of surveys, the possible fluid flow relations along the fringe zone of the gas cap were also investigated. In respect of possible fluid flows the side-mouth bars were assigned to have the highest flow potential. Nevertheless, the flows starting from these sand bodies do not reach the gas cap and vice versa. In this sense the common crevasse splays were considered to be isolated lenses, in turn with their interfingering where smaller flows can occur. As a potential risk factor the extreme proximity of flow-paths starting from the mouth bars was diagnosed in the northern margin of the gas cap. 
The results covering three scales of interest were presented in frequency histograms, in factor analysis, in box-plots, in sand content contour-maps and other grid-based maps as well as autocorrelograms, vectorial grids and core photos.

The new results of this thesis can aid a clarification of the former model to gain a better understanding of the processes within the reservoir body. This may enhance more accurate planning of certain measures, a more secure operation of the storage, and aid occasional problem solving as well as the assignment of new wells in the future. 